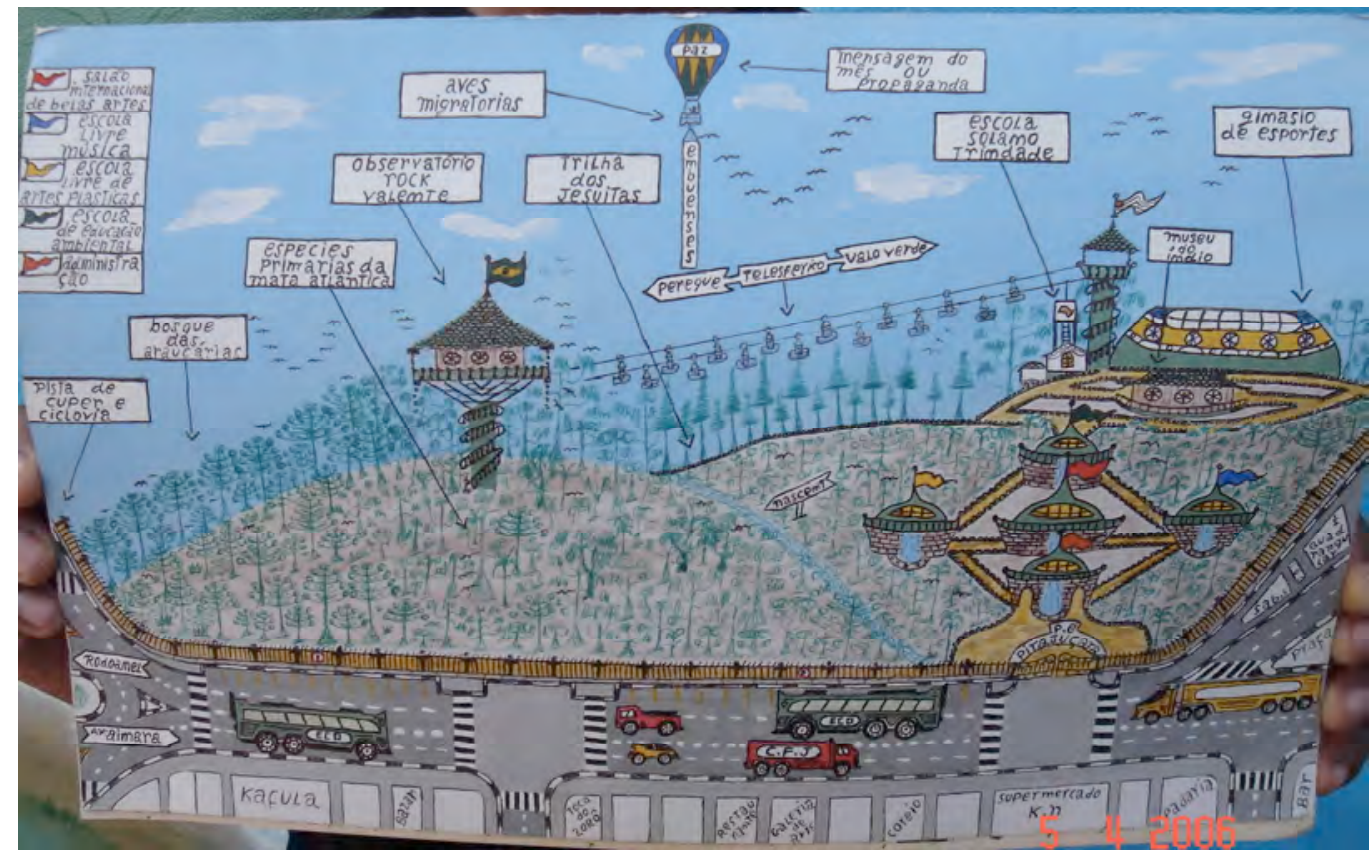

\title{
VENTOS JOVENS NA PAISAGEM
}

\author{
Dissertação de Mestrado \\ Thea Standerski
}

Orientadora

Prof ${ }^{a}$. Dr ${ }^{a}$. Catharina Pinheiro Cordeiro dos Santos Lima

$$
\text { FAU USP }
$$

Faculdade de Arquitetura e Urbanismo

\author{
Área de Concentração \\ Paisagem e Ambiente
}

São Paulo - 2007 
AUTORIZO A REPRODUÇÃO E DIVULGAÇÃO TOTAL OU PARCIAL DESTE TRABALHO, POR QUALQUER MEIO CONVENCIONAL OU ELETRÔNICO, PARA FINS DE ESTUDO E PESQUISA, DESDE QUE CITADA A FONTE.

ASSINATURA:

E-MAlL: thea@goya.com.br

Standerski, Thea

S785v Ventos jovens na paisagem / Thea Standerski. - - São Paulo, 2007.

$$
2 \text { I p. : il. }
$$

Dissertação (Mestrado - Área de Concentração: Paisagem e Ambiente) - FAUUSP.

Orientadora: Catharina Pinheiro Cordeiro dos Santos Lima.

I. Arquitetura paisagística 2. Participação comunitária

3. Espaço público 4. Jovens I. Título 


\title{
VENTOS JOVENS NA PAISAGEM
}

\author{
Dissertação de Mestrado \\ Thea Standerski \\ Orientadora \\ Prof ${ }^{a}$. Dr ${ }^{a}$. Catharina Pinheiro Cordeiro dos Santos Lima
}

FAU USP

Faculdade de Arquitetura e Urbanismo

Área de Concentração

Paisagem e Ambiente

São Paulo - 2007 
A Lilia, Nina e Rita, as flores preferidas do meu jardim.

Ao Paulo, minha energia. 


\section{ÍNDICE}

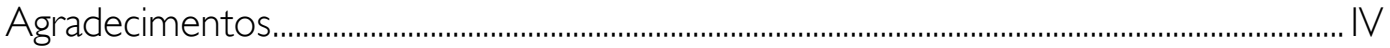

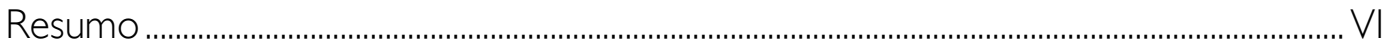

Abstract..............................................................................................................................

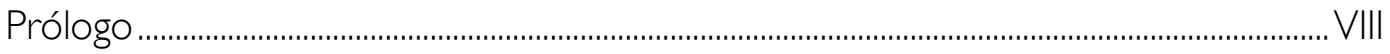

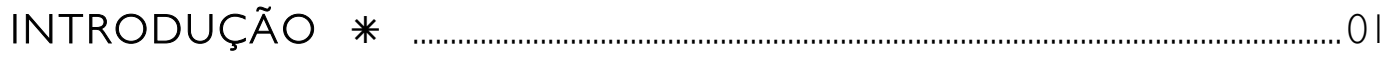

$\begin{array}{ll}\text { CAPÍTULO I os Princípios } & 07\end{array}$

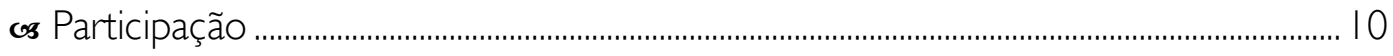

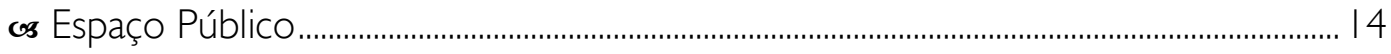

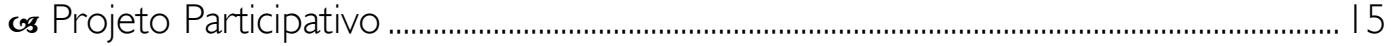

os Educação Ambiental .......................................................................................................... 22

os Um Giro pelo Mundo.......................................................................................................... 25

• Projeto Bacias Irmãs .............................................................................................25

• Uma Fruta no Quintal......................................................................................... 27

- Praça em frente a um colégio............................................................................28

- Planos Diretores dos Municípios de São José e Itajaí .................................29

- Project for Public Spaces.................................................................................... 3 I

• Esterni ..................................................................................................................... 32

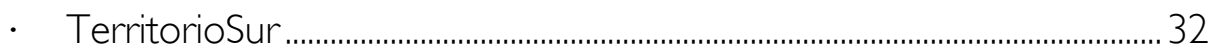

- CYE - Crianças, Jovens e Ambiente................................................................ 34

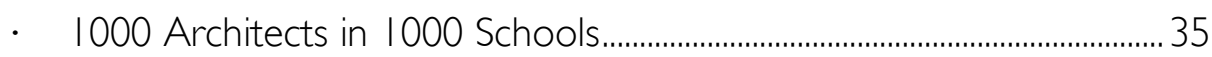

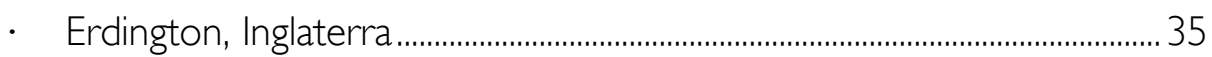

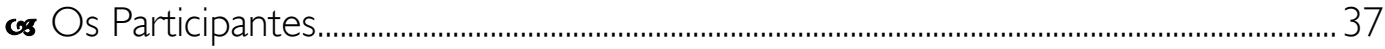

os Papel do Arquiteto Paisagista ..................................................................................................... 39

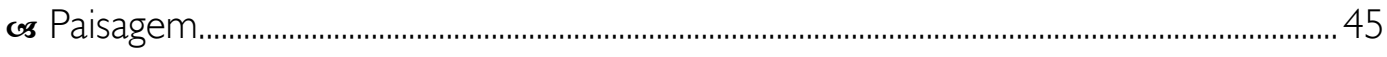

os A Geografia e o Lugar da História .......................................................................................... 50

- A construção da história num contexto pedagógico.................................54

co $\bigcirc$ que Esperar de Processos Participativos?...........................................................................56 
$\diamond$ Experiências no Brasil...................................................................................................................6 60

- Parque Chácara das Flores............................................................................... 61

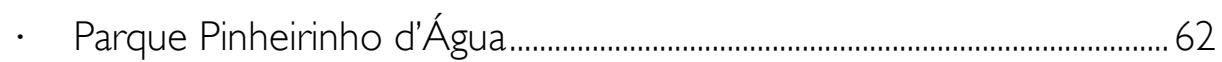

- Escola Estadual Alberto Torres.........................................................................66

- Colégio Ítaca ..........................................................................................................77

- Programa Escola que Vale....................................................................................93

- Primeira oficina .......................................................................................94

• Segunda oficina............................................................................ 104

• Oficinas São Paulo 450 Anos....................................................... 107

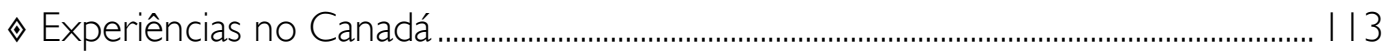

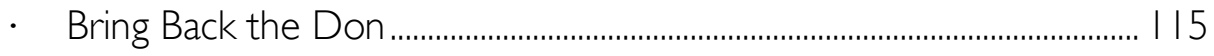

• Lost Rivers Walk............................................................................................. 117

- Dufferin Grove Park ..................................................................................... 123

- Feira de degustação de alimentos............................................... 123

- Pizza comunitária............................................................................... 125

- Construção de adobe para crianças.......................................... 126

- Night of Dread................................................................................ 128

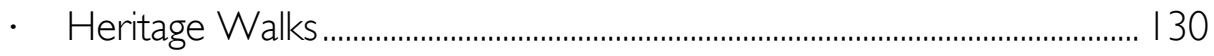

• Discovery Walks............................................................................................ 132

. 'Car-free day' - Concord Street .................................................................. 132

• Toronto Music Garden .................................................................................... 133

$\diamond$ Growing Up in Cities (GUiC) - uma rede mundial............................................... 134

- Oficina Vancouver ........................................................................................... 138

• Oficina São Paulo .............................................................................................. 139

CAPÍTULO 3 回 Polifonia adolescente I44

回 Jovens em Ação ........................................................................................................................ 145

回 A Opção por Jovens .................................................................................................................. 44

回 Deflagrando o Processo .............................................................................................................. 160

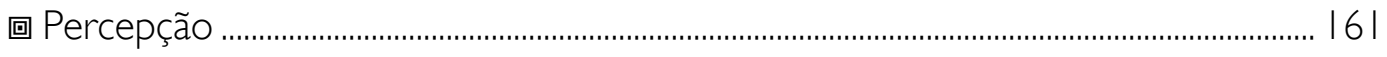


• Elementos visíveis...................................................................................... 162

. A Trama .............................................................................................................. 163

回 Utopia e Sonho ..................................................................................................................... $\mid 64$

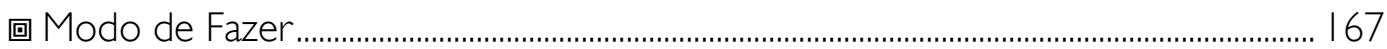

• Comunicação................................................................................................... 167

- Arte

• Estímulos .......................................................................................................... $\mid 70$

• Organização ……………………………………………………………... 172

- Interdisciplinaridade .............................................................................................. 173

- Processo/continuidade.................................................................................... $\mid 74$

• Liderança ............................................................................................................. 175

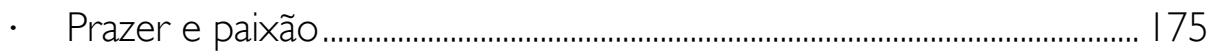

- Responsabilidade e pertencimento …………............................................... 177

- Superação de conflitos .................................................................................. 178

- Grandes miudezas................................................................................................... 179

回 Metodologias/Técnicas/Ferramentas ................................................................................. $\mid 80$

- Estudos do meio ................................................................................................ $\mid 80$

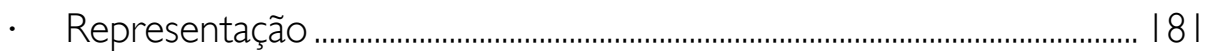

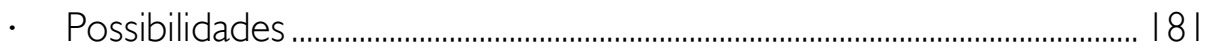

• Documentação ........................................................................................... 182

回 Avaliação............................................................................................................................ $\mid 83$

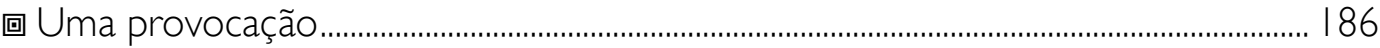

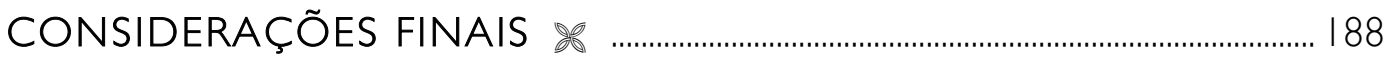

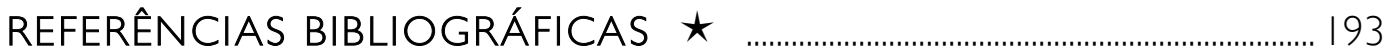

ANEXOS ^ 


\section{AGRADECIMENTOS}

Tantas são as pessoas cujos corações e mentes estão neste trabalho! Talvez eu me esqueça de algumas. Agradeço...

Meus pais, Hinda e Icek, por eu existir e pelo amor às crianças..

Catharina Lima, por acreditar em mim.

Laura Góes, por me ensinar a gostar de flores.

Helena Mirabelli, Sylvia Magaldi, Marina Ribeiro Leite, Julieta Ribeiro Leite, Clóvis Bojikian, Maria Thereza Fraga Rocco, Odenis Módulo, professores do Colégio de Aplicação, que estiveram ao meu lado na minha caminhada, quando jovem e me ensinaram que somos capazes de muita coisa e devemos querer sempre mais.

Euler Sandeville Jr., Hugo Segawa, Jorge Oseki, José Guilherme Magnani, Maria Ângela Pereira Leite, Nídia Pontuschka, Paulo Pellegrino, Reginaldo Ronconi, Siegbert Zanettini, Silvio Macedo, Vera Pallamin e Vladimir Bartalini, professores que me guiaram em diferentes momentos do período do mestrado e em especial Eugênio Queiroga e Pedro Jacobi, pelos comentários e orientações no Exame de Qualificação e Chris Cavanagh pelas estórias encantadoras.

André Graziano, Daniela Ramalho, Glauco Coccozza, Isabella Barbosa, Juliana Gotilla, Nagírley (Gila) Kessin, Roberto Vignola, Pierre França e especialmente a Paulo Gonçalves, pela cessão de algumas fotos, Ísis Vidal, pela dica da bolsa do Programa Bacias Irmãs, Fany Galender, por não me deixar desistir, e Raul Pereira, por me apresentar à Profa Catharina, todos estes, colegas do grupo de orientandos da mestra.

Adriana, Daniela Viana, Guilherme Mazza Dourado e Luiz Portugal, pelas tardes de estudo.

Cristina, Filomena e Isa, da secretaria e biblioteca da FAU Maranhão.

A equipe do CEDAC, Fernanda Savoldi, Maria Cristina Ribeiro Pereira e Tereza Perez Soares pelo convite e apoio às oficinas.

Mercedes de Paula Ferreira, pelo incentivo ao trabalho no Colégio Ítaca.

Guila Flint, pela palestra apresentada aos alunos do Colégio Ítaca.

Marcia da Penha Rezende, pelo exemplo de força, persistência e perseverança.

Os colegas do Projeto Bacias Irmãs, Andréa Moraes, Alexandre Rathsam e Fabiana Barbi pelo companheirismo e amizade. 
Os colegas canadenses, Aneela Bisram, Arlita McNamee, Bob Isenberger, Claudia de Simone, David Anderson, Johanna Reynolds, Laura Reinsborough, Liz Forsberg, e Mandy Bergman, que me ajudaram a compreender a sua cultura.

David Driskell, por também acreditar em mim. entusiasmo.

Carly Fox, Sage Ferguson e toda a equipe do GUiC, pelo companheirismo e

Rui Fontana Lopez, pelos auxilios luxuosos com a língua portuguesa.

Pierre Ruprecht, pelas fotos dos trabalhos dos professores de Marabá.

David Mezlin, pela entrevista concedida.

Ciça Gorski, por um relato de experiência.

Hilda Liberman, que me ensinou o valor das estórias de tradição oral.

Marcelo Cecchi, que tem me ensinado a 'fazer'.

Renato Marcondes, que me acompanhou na trilha que me trouxe até aqui.

Todas as crianças, jovens e adultos que participaram das oficinas.

Meus amigos/irmãos que em certos momentos desta jornada me deram algum alento, Bia Blandy, Carola Young, Cida Lico, Cynthia Bianchi, Denise Ruprecht, Elisa Grinspum, Irene Gevertz, Neusa Fornasier, Simone Alcântara, Sonia Manski, Vera Cipis, Tito Cavalcanti, e todos os outros, pela amizade, sempre.

Rita Rosa de Araújo, por cuidar da minha casa durante minhas ausências.

Angela Maria Mendes de Santana, pelos recados, almoços e cafés.

Todos os jovens e crianças do mundo, pela inspiração.

Um agradecimento especial a Eliezer (esq.) e Meola, dois jovens moradores do Embu, que lutam pela criação do Parque Ecológico Pirajuçara.

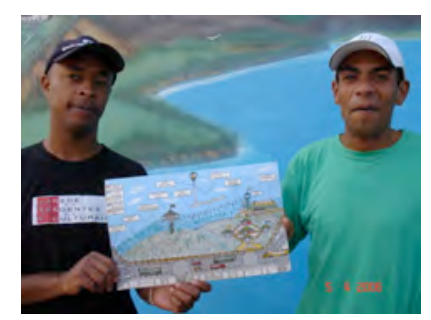

A imagem da capa deste trabalho é a proposta de Meola para o parque. 


\section{RESUMO}

Este trabalho busca refletir sobre a participação da sociedade em práticas coletivas que estimulem a percepção e a construção das paisagens de seus lugares de vida. Dentro desse universo discute-se os papéis e pertinências do trabalho do arquiteto paisagista nessas práticas, que devem ser sempre interdisciplinares.

Nesse âmbito, foi colocado foco sobre a participação de jovens, entendendo seu potencial de curiosidade, idealismo, energia, capacidade produtiva, criatividade e sonho, e reconhecendo a necessidade premente de sua inclusão nas decisões que afetam suas vidas. Procurou-se adentrar o universo de práticas que contribuam para torná-los sujeitos de sua ação.

Tomando-se como referência projetos desenvolvidos no Brasil e em outras partes do mundo, em que os jovens tenham atuado como protagonistas, foi dada ênfase aos espaços livres públicos como objetos de estudo e apropriação, pois é este o objeto da arquitetura paisagística.

Identificou-se, ao longo do trabalho, um campo de investigação profícuo para o aprofundamento do conhecimento acerca de práticas participativas com jovens na paisagem no que toca sua documentação e avaliação.

Palavras-chave: paisagem, jovens, participação, espaço livre público. 


\begin{abstract}
The purpose of this paper is to reflect on community participation in collective practices that stimulate perception and construction of the landscapes of the places they live in. Within this universe we discuss landscape architects' roles and the appropriateness of their work in these practices, which should always be interdisciplinary.

Taking this into consideration, focus was given to youth participation, understanding their curiosity, idealism, energy, productive ability, creativity and dreaming potential, and recognizing the urgent need for their inclusion in decisions that affect their lives. The paper discusses practices that can help them guide their own lives.
\end{abstract}

Taking projects developed in Brazil and in other parts of the world as reference, emphasis was given to public open spaces as object of study and appropriation, for this is landscape architecture's subject matter.

It was identified a rich field for further research on youth participatory practices within the landscape in what relates to documentation and assessment.

Key words: landscape, youth, participation, public open spaces. 
PRÓLOGO 
I "No one is born a good citizen; no nation is born a democracy.

Rather, both are processes that continue to evolve over

a lifetime. Young people must be included from birth. A society that cuts itself off from its youth severs its lifeline; it is condemned to bleed to death."

Kofi Annan ${ }^{3}$

Gostaríamos de começar este trabalho dizendo que, antes de tudo, acreditamos no potencial que crianças, jovens, homens e mulheres têm para transformar a realidade, por mais brutal que ela possa ser. Temos visto guerras absurdas, conflitos cruéis e devastadores e sabemos que há dentro de nós um potencial enorme para esses conflitos. Mas nossa aposta é em nosso outro lado: o da solidariedade, da cooperação, do respeito ao outro, da paz. E temos a convicção de que a educação é uma excelente ferramenta para que se desenvolva essa dimensão positiva da nossa humanidade. Somos seres sociais, vivemos em comunidade, então é aí que devemos nos educar - no grupo. Entendemos que a educação de uma pessoa ocorre em três instâncias: a familiar, a escolar e a social. Sendo este um trabalho de profissionais da arquitetura e da arteeducação, a instância familiar fica obviamente fora de seu âmbito; a instância escolar, curricular, será intencionalmente deixada de lado pois ela exigiria uma abordagem

\footnotetext{
I O original, em língua estrangeira, de todas as citações, encontra-se nas notas de rodapé. As citações que estão na língua original no corpo do texto têm sua tradução em notas de rodapé;. Todas são traduções livres.

2 "Ninguém nasce sendo um bom cidadão; nenhuma nação nasce sendo uma democracia. Ao invés disso, ambos são processos que se desenvolvem ao longo da vida. Os jovens precisam ser incluídos desde o nascimento. Uma sociedade que se desvincula de seus jovens rompe a sua corda de salvamento; está condenada a sangrar até a morte."

3 In World Youth Report - Capítulo "Youth Participation in Decision-making" - Department of Economic and Social Affairs (ESA), United Nations, 2003.
} 
bastante diferente desta a que nos propusemos aqui. Esta persegue a idéia de que é possível se construir conhecimento através da interação entre diferentes grupos sociais.

Como pessoas, é fundamental a honestidade, a simplicidade, a capacidade de ouvir, de conversar de respeitar; e, transversal a tudo isso, acreditamos no humor, na leveza e na brincadeira como elementos indispensáveis ao ensino-aprendizagem, principalmente com jovens. "... saber e sabor são sinônimos, embora, com freqüência, esqueçamos que essas palavras têm significados semelhantes e, dessa forma, tornemos um tanto insossas nossas ações para conhecer algo." (PERROTTA, p.7I) É preciso haver sabor no saber, para que o conhecimento se torne algo desejável. E com relação ao fato de colocarmos dois conceitos numa mesma palavra composta (ensino-aprendizagem): pensamos neles como parte de um processo único - um não existe sem o outro. Se você pensa que ensinou, mas o outro não aprendeu... você não ensinou. E se alguém aprendeu mesmo sem o outro ensinar intencionalmente, não é porque não o tenha feito, mas porque talvez o tenha feito sem intenção. É claro que estamos falando de situações de ensino-aprendizagem, se não formais, num do contexto escolar, ao menos organizadas.

A construção de conhecimento tem condições muito favoráveis em situações de grupo, onde existe possibilidade de diálogo, em ambientes onde há respeito ao conhecimento de cada um dos participantes do grupo, seja ele qual for. Será através desse diálogo, do levantamento de hipóteses, de testes acerca dessas hipóteses, de apropriações criativas da realidade, da troca de saberes e do interesse comum que se dará a construção de novos conhecimentos. Tais conhecimentos poderão ser subsídios para a atuação democrática sobre as paisagens dos lugares de vida das pessoas.

No mês de maio deste ano (2007), a prefeitura de São Paulo organizou a 'Virada Cultural', um evento de eventos - "três milhões e quinhentas mil pessoas compareceram a mais de 300 espetáculos diferentes (populares e eruditos) unindo música, teatro, circo, dança e muitas coisas mais; só no Centro, foram construídos cinco palcos grandes e mais uma infinidade de pequenas instalações, como um teatro de arena na Praça da República ou um cirquinho na esquina da Sete de Abril com a Praça D. José Gaspar; mas o evento ocupou também todos os CEUs da cidade, vários teatros, 
incluindo o Municipal e o São Pedro, igrejas, praças da periferia, o diabo a quatro", ao longo de 24 horas. Chamou a atenção o comentário de muitas pessoas, principalmente jovens que lá estiveram, que disseram que nem era preciso assistir a nenhum espetáculo; apenas estar ali, andando pela rua, com gente sentada na grama, o Teatro Municipal iluminado, encontrando amigos e conhecidos, vendo outras 'tribos', já tinha valido a pena - "famílias inteiras, gente de periferia, mocinhas hippies, 'patricinhas', moicanos de preto, darks de casacos escuros arrastando pelo chão, carecas tatuados, malucos de todos os quadrantes";; eventos dessa natureza, enfim, contribuem para o fortalecimento do espaço público no que permitem uma apropriação plural, abrigando a diversidade cultural e social.

Propomo-nos aqui a refletir sobre como nós, arquitetos paisagistas, podemos interagir com os jovens para, juntos, construirmos um corpo de conhecimentos que nos permita, se não agir imediatamente, caminhar nesse sentido capacitando-nos para discutir e propor transformações para nossos lugares de vida para que eles se tornem cada vez mais parecidos com os nossos sonhos.

\footnotetext{
${ }^{4}$ Relato de uma pessoa que passou 10 horas circulando pelo centro da cidade, assistindo a alguns dos espetáculos, além de tomar um 'banho de multidão', segundo suas próprias palavras.

5 José Guilherme Cantor Magnani é professor da FFLCH USP (Faculdade de Filosofia e Ciências Humanas da Universidade de São Paulo); ele fez um estudo antropológico dessas que ele denomina de 'tribos urbanas', que pode ser lido no livro organizado em parceria com Lilian de Lucca Torres, "Na Metrópole: Textos de Antropologia Urbana", São Paulo: EDUSP, 1996.

${ }^{6}$ Idem nota 4
} 
INTRODUÇÃO 
"Uma medida comum da limpeza de um rio na montanha

é a existência de trutas. Se elas são encontradas, o habitat é saudável. É mesma coisa com crianças na cidade. Crianças são um tipo de indicador de espécie. Se pudermos criar uma boa cidade para as crianças, teremos uma boa cidade para todos."

Enrique Penãlosa, duas vezes prefeito de Bogotá, Colômbia

Este trabalho surgiu de uma inquietação com a formação dos jovens brasileiros, pois o Brasil vive um momento crítico no que diz respeito à sua educação, momento este apresentado de maneira muito clara e contundente no documentário brasileiro "Pro Dia Nascer Feliz", de 2005, dirigido por João Jardim. Além disso, muitos jovens têm que trabalhar muito cedo, enquanto ainda estudam, e outros tantos precisam parar os estudos para trabalhar e garantir seu sustento e/ou de sua família. Seria muita pretensão pensar em apresentar aqui soluções para essa situação. Nossa intenção é simplesmente refletir sobre nossa possível contribuição, como arquitetos paisagistas. Assim como todos outros atores da sociedade, temos contribuições a dar nesse processo.

No mundo, a distribuição de riquezas é desigual, mas a distribuição de inteligência e criatividade não; esta é relativamente equilibrada. Todo e qualquer jovem tem habilidades, talentos, capacidades, potencial criativo e inteligências que merecem a atenção da sociedade no sentido de lhes oferecer condições dignas para seu pleno desenvolvimento. Este trabalho, que tem um caráter educativo, procura pensar práticas que possam dar continente à expressão dos jovens em seu caminho para a conquista da cidadania e de maior poder de ação sobre suas próprias vidas. $\bigcirc$ trabalho com jovens aqui proposto caminha no sentido da promoção de processos emancipatórios e libertários, incentivando-os ao domínio do entendimento da paisagem de seus lugares de vida como uma das formas de inclusão na sociedade. 
A complexidade urbana contemporânea demanda subsídios de várias disciplinas e a arquitetura paisagística tem uma perspectiva de síntese que viabiliza a integração, através de práticas interdisciplinares, de questões referentes a espaço, vegetação, água, morfologia da paisagem, conforto ambiental, materiais e técnicas construtivas e de plantio, desenvolvimento da sensibilidade estética, visão do ambiente urbano como ecossistema, perspectivas da importância dos espaços livres na cidade e tantas outras. Essa abordagem abre um amplo leque de possibilidades para que os jovens tenham opções diferenciadas de expressão e ação; ela tem um potencial de combater o sentimento de indiferença com relação ao seu ambiente, e propiciar a construção de conhecimentos significativos para suas vidas. Práticas participativas que valorizem seus talentos e que os transportem para o caminho do prazer do conhecimento, do prazer estético, do prazer do saber e do prazer do criar, são opções à violência, e podem re-estabelecer sua capacidade de sonhar e de agir. No livro "Utopia" (MACBRIDE, 2005), sobre o qual falaremos adiante, são apresentadas propostas para a cidade de Toronto que fazem do sonho o motor da ação. É preciso desenhar o sonho para que ele comece a tomar forma.

A forma, se não única talvez a mais eficiente, de buscar soluções para os problemas que afligem os jovens é o diálogo. Se se pretende propor a eles atividades, trabalhos, vivências, estudos ou pesquisas, é indispensável sentar-mo-nos juntos para estabelecer uma conversa, interagir, trocar informações, interesses, angústias, incertezas e tudo o mais, pois eles não são objetos do nosso trabalho, e sim nossos parceiros. Nossa proposta é de investigação, diagnóstico, pesquisa, análise da paisagem, juntamente com a elaboração de propostas de mudança dessa paisagem.

Essas são as idéias que estruturaram o impulso inicial deste trabalho e que forneceram subsídios para a reflexão acerca de algumas experiências, indicando determinadas direções de trabalho.

Sabemos que os jovens são frequentemente alijados de processos de decisão que dizem respeito aos seus lugares de vida, mas são eles os personagens principais desses processos. Eles são a nossa continuidade, uma possibilidade do 
novo, da transformação, são eles a nossa história futura e nossos parceiros para construí-la.

\section{O PROBLEMA}

A cidade onde vivemos passa despercebida aos olhos de muitos - cidade como paisagem, como materialidade, como simbologia, como expressão dos processos sociais e naturais que a compõem e constroem. A percepção, e conseqüente compreensão da paisagem, não raro encontra-se embotada e fragmentada, sem que se revelem os processos que lhe são subjacentes, e sua consciência seria de extrema importância para que houvesse maior condição cidadã de participação em sua construção e transformação.

Processos de projeto de áreas livres públicas e a convivência informal com jovens nos fizeram ver que existe uma espécie de 'cegueira' com relação ao ambiente em que se vive. Muitos moradores de São Paulo, de diferentes classes sociais, origens e formações desconhecem aspectos históricos, geográficos, sistêmicos e sócio-ambientais de sua cidade. Dentre tantos outros, um aspecto gritante dessa desconexão é o fato de as cidades terem se tornado organismos que parecem não fazer parte da natureza. Na cidade de São Paulo ela foi praticamente escondida pelo tecido urbano. As pessoas vivem como se nela não ocorressem processos naturais; mas aqui correm rios, chove e cresce vegetação. Não temos montanhas que nos mostrem de forma explícita o relevo sobre o qual a cidade se assenta, mas seu relevo, suave, está presente. Noções como a de que a cidade de São Paulo tem um espigão (Av. Paulista), que é divisor das águas dos rios Tietê e Pinheiros; que o rio Tietê nasce no alto da Serra do Mar e corre, não para o mar, mas sim para o interior; que o curso do rio Pinheiros é eventualmente invertido; que várias avenidas foram construídas sobre leitos de rios que hoje estão escondidos, entre outras, não são presentes.

Anne Spirn, em um de seus livros', discute em profundidade essa questão e suas idéias serão retomadas ao longo de nosso trabalho. Alguns outros autores também discutem essas idéias no livro "Urban Place - Reconnecting with the

\footnotetext{
I SPIRN, Anne Whiston - "Jardim de Granito”, São Paulo: EDUSP. 1998.
} 
Natural World"2, que apresenta alguns projetos no sentido da reconexão das pessoas com processos e/ou elementos ditos naturais tais como hortas urbanas, cozinhas e jardins comunitários, jardins de cura, projetos de recuperação de florestas urbanas e outros.

Qualquer momento da vida é propício à formação, à educação, mas os jovens têm um grande potencial de aprendizagem e são, frequentemente, tratados como irresponsáveis sendo, ora alijados de responsabilidades ora investidos delas sem que sejam preparados para isso. Não falamos aqui de uma preparação prévia e sim através do fazer. Contardo Caligaris diz que a adolescência é tratada pela sociedade atual como um período da vida em que se fica "em suspenso", aguardando o momento em que se poderá finalmente atuar, "ser adulto". Mas como é que alguém pode, de repente, virar adulto? É preciso passar por experiências, erros e acertos, e a adolescência é um período excelente para isso.

\section{OBJETIVO}

Este trabalho tem como objetivo apontar algumas possibilidades de práticas que contribuam para que os jovens sejam envolvidos no processo de transformação de seus lugares de vida, através da análise de algumas experiências de leitura de paisagem feitas com moradores de cidades (não apenas jovens). A partir do momento em que se tem uma melhor percepção e compreensão da paisagem, de seu ambiente, pode-se atuar mais ativamente como cidadão/ã.

\section{OBSERVAÇÃO}

Durante o período do mestrado, em 2005, participei de um intercâmbio do Programa Bacias Irmãs ${ }^{3}$, tendo estudado por um semestre na Escola de Estudos Ambientais da Universidade York, em Toronto, Canadá. Algumas atividades das quais participei em minha estadia naquela cidade enriqueceram muito minha visão não apenas de possibilidades de participação popular no espaço público, mas

\footnotetext{
2 BARLETT, Peggy - "Urban Place", Massachusetts: MIT Press, 2005.

3 www.baciasirmas.org.br - uma parceria da USP (através do PROCAM - Programa de Ciências Ambientais) com a Faculdade de Estudos Ambientais da Universidade York e o Instituto Ecoar.
} 
também do caráter desse espaço. Pude participar de algumas atividades desenvolvidas para estimular a percepção das pessoas no que diz respeito à sua cidade - história e elementos naturais, observando diferenças significativas com relação ao Brasil. Devido à freqüência a um curso na universidade, e participação em atividades de extensão, foram feitas muitas consultas a bibliografia estrangeira, o que permitiu a visão do movimento de inclusão de jovens em termos mundiais.

O primeiro capítulo desta dissertação discute o conceito de participação e os diferentes entendimentos que se tem dela em projetos urbanos de espaços livres públicos junto a comunidades, sejam de planejamento, paisagismo, urbanismo ou outra área que tenha como objeto a paisagem. Esta discussão embasou os objetivos da dissertação no que diz respeito às formas de atuação e de atitude nos trabalhos em parceria com grupos de jovens.

O segundo capítulo apresenta uma série de experiências de trabalho em parceria com a comunidade que vão desde a leitura de uma paisagem - como etapa do processo de compreensão do lugar de vida das pessoas - até a elaboração de propostas para a sua transformação. A partir dessas experiências pudemos refletir sobre seus objetos de trabalho, seus objetivos, processos, estratégias, ferramentas, práticas, produtos e avaliação.

No terceiro capítulo, são explicitadas as razões para a opção por trabalhos com jovens e algumas questões pertinentes a trabalhos participativos no que diz respeito a suas diretrizes, contemplando os aspectos e questões levantados no capítulo anterior.

As considerações finais apontam alguns rumos para futuras investigações acerca da documentação e avaliação de práticas participativas com jovens na paisagem. 
CAPÍTULO I

Princípios 
Cidade. S. f. I. Complexo demográfico formado, social e economicamente, por uma importante concentração populacional não agrícola, i. e., dedicada a atividades de caráter mercantil, industrial, financeiro e cultural; urbe.

Cidadão. S. m. I. Indivíduo no gozo dos direitos civis e políticos de um Estado, ou no desempenho de seus deveres para com este.

Cidadã. S. f. Fem. De cidadão.'

A idéia de cidadania é plena da noção de direitos e deveres, o que implica diretamente no conceito de participação da sociedade nos desígnios que the dizem respeito, no sentido da fruição e da atuação; ela é fundamental como direito do cidadão no estado democrático.

A participação dos cidadãos na discussão e gestão de sua cidade e, em particular, de seus espaços livres públicos, não é apenas seu dever, mas também seu direito. É atribuição do cidadão, como tal, conhecer seu lugar de vida, saber das coisas que acontecem ali, porque se passam daquela forma, dedicar-se às decisões que dizem respeito a ela, envolver-se com a sua história. A ação de vários atores da sociedade em processos dialógicos, que permitam a percepção, a colocação, a discussão e a busca de soluções para as demandas, problemas, limitações, sonhos, necessidades, imposições que se apresentem é uma das maneiras possíveis de se alcançar esse conhecimento a respeito da cidade em que se vive. Processos de

\footnotetext{
' FERREIRA, Aurélio Buarque de Holanda - "Novo Dicionário da Língua Portuguesa", São Paulo: Ed. Nova Fronteira, la edição.
} 
natureza participativa são palco de consensos e conflitos - inevitáveis nesse contexto - que, sendo objetos de reflexão, impulsionam a busca de soluções; eles propiciam o debate; se respeitados todos os participantes e as questões trazidas por eles, favorecem soluções criativas; também obrigam ao confronto, que deve ser destrinchado em suas razões e argumentos, para que se possa chegar a resultados consensuais que atendam se não a todos, à maioria, sem que haja prejuízo significativo para nenhuma das partes.

É imprescindível que se leve em conta o poder e a força de cada grupo, e que se dê suporte às partes mais frágeis, mas é certo que, com o conhecimento técnico, social, ecológico, econômico, ambiental, espacial, e outros, que se tem hoje, com o amplo acesso à informação, e, principalmente, com o potencial criativo do ser humano, é possível vislumbrar inúmeras possibilidades de soluções. A resolução de conflitos é uma área à qual se dá muita atenção em processos participativos que envolvem diferentes grupos de interesse. "Considerando que o conflito é parte de qualquer sociedade ou atividade humana, a resolução de conflitos... busca converter interesses conflitantes em cooperação construtiva; se administrado de forma apropriada, conflitos podem ser catalisadores para a aquisição de meios de desenvolvimento mais sustentáveis através da construção de consenso e ação conjunta."'2 (UN-HABITAT, 2003: 87)

É claro que não podemos ignorar as inúmeras e imensas dificuldades que temos aqui no Brasil de estabelecer processos dessa natureza. As desigualdades sócio-econômico-culturais são gigantescas e sabemos que elas relegam uma parcela enorme da população a condições de vida muito abaixo da dignidade, segregando classes sociais de forma que elas não convivam de maneira equilibrada, cidadã, equânime, respeitosa. As forças sócio-econômicas que agem sobre essa situação são poderosas e precisam ser consideradas, mas não serão objeto deste trabalho.

\footnotetext{
2 "Acknowledging that conflict is part of any human society or activity, conflict resolution... seeks to convert conflicting interests into constructive cooperation; if properly managed, conflicts can be catalysts to achieving more sustainable means of development through consensus building and joint action."
} 


\section{PARTICIPAÇÃO}

A participação de cidadãos comuns na discussão e gestão da cidade não é um fenômeno novo, e vem recentemente sofrendo transformações importantes no Brasil. Na década de 60 aconteceram inúmeros movimentos sociais urbanos, principalmente movimentos de moradia com os grupos de mutirão de construção. Em 1988, início da redemocratização do país, as pessoas estavam desejosas de participar, depois de muito tempo impedidas dessa prática. $\bigcirc$ Estatuto da Cidade, editado então, veio legitimar e dar caráter legal e obrigatório à participação de cidadãos na discussão de questões referentes às suas cidades. Em seu texto a idéia de participação aparece inúmeras vezes, como podemos ver abaixo:

"Das Diretrizes Gerais

II - gestão democrática por meio da participação da população e de associações representativas dos vários segmentos da comunidade na formulação, execução e acompanhamento de planos, programas e projetos de desenvolvimento urbano;

Dentre os instrumentos gerais desta lei:

f) gestão orçamentária participativa;

$\S 30$ Os instrumentos previstos neste artigo que demandam dispêndio de recursos por parte do Poder Público municipal devem ser objeto de controle social, garantida a participação de comunidades, movimentos e entidades da sociedade civil.

Das operações urbanas consorciadas:

§ 10 Considera-se operação urbana consorciada o conjunto de intervenções e medidas coordenadas pelo Poder Público municipal, com a participação dos proprietários, moradores, usuários permanentes e investidores privados, com o objetivo de alcançar em uma área transformações urbanísticas estruturais, melhorias sociais e a valorização ambiental.

Da gestão democrática da cidade:

Art. 44. No âmbito municipal, a gestão orçamentária participativa de que trata a alínea f do inciso III do art. 4" desta Lei incluirá a realização de 
debates, audiências e consultas públicas sobre as propostas do plano plurianual, da lei de diretrizes orçamentárias e do orçamento anual, como condição obrigatória para sua aprovação pela Câmara Municipal.

Art. 45. Os organismos gestores das regiões metropolitanas e aglomerações urbanas incluirão obrigatória e significativa participação da população e de associações representativas dos vários segmentos da comunidade, de modo a garantir o controle direto de suas atividades e o pleno exercício da cidadania."”

Essa lei deu novo impulso a ações que envolvem a participação da população urbana no Brasil e validou as que já vinham ocorrendo. O Ministério das Cidades criou então um movimento nacional para construir cidades inclusivas, democráticas e sustentáveis, propondo a revisão ou elaboração do Plano Diretor de todos os 1.700 municípios brasileiros com população acima de 20 mil habitantes ou integrantes de regiões metropolitanas e aglomerações urbanas. Esse movimento prevê um processo que estimule a população a pensar e discutir a cidade onde mora, trabalha e sonha, e fazer propostas para corrigir as distorções existentes no desenvolvimento do município, devendo o plano ser um pacto sócio-territorial que de fato transforme a realidade dessas cidades. ${ }^{4}$

"A participação da população é o elemento novo na proposta de planejamento e gestão urbanos previsto no Estatuto da Cidade, capaz de produzir mudanças mais significativas nas cidades e talvez o mais difícil de se concretizar, pois não acontece por decreto ou por força de lei (mesmo que a existência desta lei ajude no processo, como é o caso da Lei do Estatuto da Cidade, mas que por sua vez foi o resultado de uma mobilização social). O processo participativo acontece dependendo do nível de amadurecimento dos movimentos sociais e envolvimento da população e deve avançar para além do próprio Estatuto da Cidade, buscando ir além da conquista dos direitos à moradia e serviços urbanos.

\footnotetext{
3 Estatuto da Cidade, Lei no 10.257, de 10 de julho de 200I. (grifos nossos)

${ }^{4}$ http://www.cidades.gov.br/planodiretorparticipativo
} 
É preciso destacar a importância do Estatuto da Cidade no processo de democratização da gestão urbana bem como reconhecer os seus limites."

A lei regulamenta a participação dos cidadãos na gestão da cidade, no entanto, a existência dessa lei não garante a sua aplicação; existe, muitas vezes, um descompasso entre o que ela regulamenta e a sua execução. Pode-se dizer, por exemplo, que os processos participativos empreendidos pelas várias equipes técnicas de Planos Diretores recentes, foram desiguais, e o maior ou menor grau de engajamento da população envolvida aconteceu exclusivamente em função do senso ético mais ou menos democrático de cada equipe. Por ser essa lei (o Estatuto da Cidade) relativamente recente, a maioria das práticas que incentivam, possibilitam e propiciam a participação dos cidadãos nas discussões referentes às suas cidades são novas. Como argumentou o arquiteto Paulo Gonçalves, em seu trabalho de mestrado ${ }^{6}$, experiências participativas no Brasil são incipientes e ainda pouco estudadas, mas é evidente que o país já tem uma história de práticas dessa natureza que podem ser mapeadas, e que incluem desde a luta dos movimentos sociais por moradia e terra para produção, até as mais recentes experiências de envolvimento da população em orçamentos participativos.

Processos de projetos participativos para espaços urbanos livres públicos têm um enorme potencial de contribuição para o cumprimento da lei no que diz respeito à idéia da participação cidadã no âmbito das cidades e neste trabalho buscamos compreender de que forma profissionais da paisagem, que são atores da sociedade civil, podem participar de trabalhos em parceria com comunidades de moradores e/ou comunidades escolares, também atores da sociedade civil, na discussão desses projetos. Especialmente nessa área, no Brasil, já existem alguns trabalhos sendo desenvolvidos. Em Fortaleza, Ceará, a organização 'CEARAH

\footnotetext{
${ }^{5}$ FACCIO, Maria da Graça Agostinho - "Plano Diretor Participativo e a construção do espaço público nas cidades brasileiras a partir do Estatuto da Cidade: possibilidades e limites" p. 6, in Cadernos de Pesquisa Interdisciplinar em Ciências Humanas, No 82 - Florianópolis, junho de 2006.

${ }^{6}$ GONÇALVES, Paulo Cássio de Moraes - "Construção Coletiva da Paisagem", Dissertação de Mestrado defendida na FAUUSP, em 2005.
} 
Periferia" ${ }^{17}$ desenvolve um trabalho junto a comunidades carentes da periferia da cidade no sentido da capacitação de cidadãos (estudantes, lideranças comunitárias, representantes de movimentos sociais em conselhos municipais) para atuar na gestão de seus lugares de vida, através de atividades de percepção e compreensão da paisagem da cidade onde moram. Um de seus objetivos é "[s]ensibilizar, informar, capacitar o movimento popular urbano, para o exercício da cidadania com autonomia"8. O Projeto Fruta no Quintal, que se originou em Diadema, foi desenvolvido em Santo André, e está presentemente acontecendo no Taboão da Serra (os três são municípios do Estado de São Paulo), discute questões da paisagem urbana (arborização, reciclagem de lixo, publico/privado, entre outras), com comunidades escolares. Em Santo André, em 2000/200 I, foi feita uma praça pública (Praça Maria Quitéria) numa parceria da prefeitura com a comunidade, a partir da iniciativa desta última. Em São Paulo, na região noroeste, um parque (Parque Pinheirinho d'Água) foi projetado em uma parceria entre prefeitura, universidade e comunidade. Há vários projetos de reurbanização de favelas que incluem processos participativos em espaços públicos. E certamente muitos outros projetos estão acontecendo pelo país afora, não sendo entretanto nosso intuito mapear todos, e simplesmente apontar para o fato de já existir um caminho sendo trilhado na busca de possibilidades, de formas de atuação em parceria entre cidadãos comuns e atores diversos da sociedade, especialmente profissionais da paisagem (arquitetos, arquitetos paisagistas, planejadores e urbanistas).

Objetivo deste trabalho é discutir formas significativas de interação entre esses dois grupos de atores - profissionais e comunidade, especialmente jovens para que realmente haja transformação (I) no sentido de melhorar o ambiente, o lugar de vida das pessoas e (2) na maneira como elas interagem com e transformam esse lugar. E nesta tarefa, a arquitetura paisagística é o campo de conhecimento que vai nos fornecer subsídios, e nos orientar para tal.

\footnotetext{
7 'Centro de Estudos, Articulação e Referência sobre Assentamentos Humanos'

${ }^{8}$ do site www.cearahperiferia.org.br, acessado em janeiro de 2007.
} 


\section{ESPAÇO PÚBLICO}

Os espaços públicos são, historicamente, o lugar do encontro, o lugar de ver e ser visto, de flanar, de passear, de flertar, de ler um livro, de tomar sol, de jogar bola, de estar com desconhecidos. Em São Paulo, a grande maioria dos espaços públicos é, ou abandonada pelo poder público, que é seu gestor, ou apropriada de forma indevida, passando a ter uso privado, ou transforma-se simplesmente em local de passagem. "Os novos bulevares [desenhados por Haussmann em Paris, no final do século XIX] incorporavam as condições para o anonimato e o individualismo, permitindo tanto a livre circulação quanto a desatenção às diferenças e ajudando, assim, a consolidar a imagem de um espaço público aberto e igualitário. Esses são exatamente os valores que estão em cheque atualmente em São Paulo e em muitas outras cidades onde o espaço público não mais se relaciona ao ideal moderno de universalidade. Em vez disso, ele promove a separação e a idéia de que os grupos sociais devem viver em enclaves homogêneos, isolados daqueles percebidos como diferentes. Consequentemente, o novo padrão de segregação espacial serve de base a um novo tipo de esfera pública que acentua as diferenças de classe e as estratégias de separação." (CALDEIRA, 2000, p.212)

Existe aqui em São Paulo uma demanda enorme por lugares onde todos possam estar - os da periferia, os do centro, os paulistanos, os estrangeiros, os jovens, os velhos, as crianças, grupos, solitários, familias, meninos e meninas. A vivência do espaço público pode ser prazerosa, divertida e enriquecedora. É evidente que a apropriação do espaço público não se dá sempre em clima de festa e celebração. Não se pode preterir a sua dimensão política, uma vez que é também o palco do dissenso, do conflito, da contradição. A configuração e a apropriação do espaço público, por sua vez, adquirem contornos diferenciados no território brasileiro; essa distinção é importante para que não se generalize uma apreensão indistinta para todas as cidades do país. No que diz respeito a São Paulo na complexidade de sua inserção metropolitana, há questões especificas a serem enfrentadas, pois trata-se de uma cidade "...fragmentada por enclaves fortificados, [onde] é difícil manter os princípios de acessibilidade e livre circulação...”, e com isso “...o caráter do espaço público muda, assim como a participação dos cidadãos na 
vida pública." (CALDEIRA, 2000: 21 I) É urgente a participação das pessoas na discussão desse espaço que é de todos.

\section{PROJETO PARTICIPATIVO}

A prática mais comum quando se elabora um projeto de paisagismo para uma área pública ${ }^{9}$ é desenvolvê-lo dentro de um escritório, seja ele de algum órgão público ou de um contratado pelo poder público para tanto. Faz-se levantamentos, entrevistas com os moradores e/ou usuários do local, tira-se fotos, estuda-se a história, prepara-se o programa, e eventualmente se discute a proposta com os moradores e/ou se os consulta, mas o projeto em si é desenvolvido por profissionais das área de arquitetura, paisagismo, engenharia e/ou planejamento. $\bigcirc$ exercício da arquitetura pressupõe o atendimento de demandas e nesse sentido sempre há algum nível de participação; no caso de um projeto público essa relação pode se estabelecer em projetos de caráter assistencialista ou paternalista.

Mas, as idéias sobre as quais nos propusemos a refletir dizem respeito ao caráter libertário e democrático que a participação tem. Através dela, moradores e/ou usuários de áreas que passarão por alguma transformação participam efetivamente do processo, como personagens que têm suas vozes ouvidas, e são realmente interlocutores no diálogo estabelecido para o diagnóstico da área em questão, a elaboração de um projeto para a mesma, a implantação desse projeto e/ou sua manutenção. Este trabalho está circunscrito a projetos participativos de paisagismo para espaços livres urbanos públicos.

A participação em duas experiências dessa natureza nos dão algumas direções de pensamento. A primeira delas é o projeto para a Favela Pintassilva, às margens da Represa Billings, desenvolvida numa parceria entre a Prefeitura de Santo André, a Universidade British Columbia, do Canadá, a Universidade de São Paulo e a comunidade local, no entanto a participação desta última foi reduzida a uma conversa com apenas uma moradora do local; a segunda experiência, a elaboração

\footnotetext{
${ }^{9}$ Nosso interesse específico é o projeto participativo em projetos de áreas livres públicas urbanas.
} 
de um projeto para o Parque Pinheirinho d'Água, descrito e analisado pelo arquiteto Paulo Gonçalves ${ }^{10}$, também desenvolvido numa parceria com a comunidade, mas desta vez em parceria com a Prefeitura de São Paulo e a Universidade de São Paulo, onde diferentemente do processo de projeto para a Favela Pintassilva, a comunidade escolar e dos moradores do entorno participou ativamente. Uma vez que temas ligados a práticas democráticas hoje fazem parte do nosso cotidiano e foram apropriados de forma laica por vários atores envolvidos nesses processos (poder público, sociedade civil, mercado, ONGs, entre outros), faz-se necessária uma reflexão mais aprofundada sobre o assunto tomando como referência alguns autores que refletiram e escreveram a respeito. Os autores aqui apresentados discutem o conceito de 'participação' e apesar de algumas diferenças, existe um certo consenso entre as várias categorizações propostas, conforme vemos a seguir.

Segundo R. Cowan, um planejador interessado em projetos participativos, a noção de 'participação' deve ser substituída pela de 'colaboração', "onde há uma compreensão muito mais clara dos diferentes papéis que as pessoas podem ter no processo de desenvolvimento e uma visão mais igualitária das relações entre elas." "' Para esse autor, para que todos possam participar desses processos, devem ter igual acesso aos sete requisitos da 'colaboração':

- informação;

- contatos com a rede;

- conhecimento de sua relação com o contexto amplo da cidade;

- $\quad$ inspiração em experiências de outros lugares;

- $\quad$ acesso a habilidades e a profissionais;

- oportunidade de colaborar com outras pessoas e organizações; e

- $\quad$ algum papel nos processos formais de planejamento através dos quais decisões de planejamento são tomadas.

\footnotetext{
${ }^{10}$ Idem nota 5

II In ADAMS \& INGHAM, 1998, p. 29
} 
Sherry Arnstein ${ }^{12}$ descreveu oito graus de participação de adultos em planejamento, nos EUA, que vão da não participação até o empoderamento' ${ }^{13}$ :

- manipulação

- terapia - (com a idéia de que a pessoa precisa ser 'tratada', e que a participação seja esse tratamento)

- informação

- consulta

- conciliação

- parceria

- poder delegado e

- controle cidadão.

A partir dessa classificação, David Wilcox, também citado no livro de Adams (p.29), identifica cinco áreas fundamentais para a participação:

- informação

- consulta

- decisão compartilhada

- ação compartilhada e

- apoio a interesses comunitários independentes.

Segundo Adams, um processo participativo aberto e responsável não deve subestimar a capacidade dos mais jovens em perceber e responder a questões criticas do seu cotidiano; essas práticas devem proporcionar aos jovens e crianças, a exposição a valores conflitantes, a restrições reais, a limites nas escolhas e a decisões difíceis. Isso sim os levaria a um real compromisso com o processo.

Finalmente, uma classificação que nos oferece uma compreensão bastante clara dos possíveis níveis de participação, é a de Roger Hart ${ }^{14}$, autor que trabalha

\footnotetext{
${ }^{12}$ Idem

13 Embora não conste das edições mais recentes de dicionários da língua portuguesa, a palavra 'empowerment' já pertence, informalmente, ao léxico das teorias sobre participação; empoderamento tem sido a tradução mais freqüente. A palavra está ligada às idéias de emancipação, confiança, auto-estima; nesse sentido, a idéia de potência substituindo a de poder, de Gilles Deleuze, nos parece mais apropriada.
} 
com crianças em projetos participativos de desenvolvimento comunitário e questões ambientais; ele distinguiu oito níveis de participação de crianças em projetos; essa categorização pode se estender para a análise da participação de jovens e adultos também:

I. manipulação - quando algo produzido por crianças é utilizado sem o seu conhecimento, ou quando elas próprias são usadas sem o seu consentimento e/ou consciência;

2. decoração - quando a criança é usada como 'suporte', transmissora de algo do qual ela não faz idéia do que seja, usando camisetas que divulguem uma causa, por exemplo;

3. 'tokenism'15 - se refere a uma política ou prática de inclusão de membros de algum grupo de minoria, criando a falsa aparência de uma prática inclusiva; essas pessoas servindo apenas como fichasímbolo dessa prática;

4. "mobilização social" - crianças participando conscientemente, mas ainda em atividades não organizadas por elas; em geral isso tem efeito de curto prazo e é preciso que tais atividades sejam rapidamente seguidas de outras genuinamente participativas;

5. consulta e informação - aqui as crianças são consultadas e informadas sobre o projeto no qual estão envolvidas, mas ainda não têm uma participação efetiva;

6. ações iniciadas por adultos, com decisões compartilhadas com as crianças - em tal situação, mesmo que as crianças não tenham competência técnica para participar ativamente até o fim do processo, elas o acompanham e são ouvidas o tempo todo;

7. ações iniciadas e dirigidas pelas crianças - essa situação é muito rara hoje em dia, mas pode acontecer; aqui não há adultos envolvidos em momento algum;

8. ações iniciadas pelas crianças, com decisões compartilhadas com os adultos - estas são atividades nas quais participam adultos a convite das crianças, reconhecendo a possibilidade de colaboração entre eles.

\footnotetext{
${ }^{14}$ HART, Roger - "Children's Participation", New York: UNICEF, 1997. Roger Hart é Professor no Programa de Pós-graduação de Psicologia do Centro da City University de Nova lorque e Co-Diretor do Grupo de Pesquisa de Ambientes para Crianças.

15 'tokenism' - por não haver tradução para a língua portuguesa, esta palavra será usada em inglês.
} 
No que diz respeito ao Estado da Arte sobre a participação de crianças e jovens, já existe uma literatura bastante específica, entretanto autores que discutiram essa questão no que diz respeito à participação de adultos, também podem nos dar contribuições passíveis de serem aplicadas no universo jovem.

Fredrik Wulz, em seu artigo "The Concept of Participation" "16, faz um retrospecto das formas de participação do arquiteto em projetos. Inicialmente, (a) tal profissional representava os desejos do cliente; (b) durante os anos 1930 surgiram os questionários para identificar as necessidades e desejos dos clientes, para projetos sociais; (c) em seguida, nos anos 1960, em reação a isso, as investigações passaram a ser regionais, respeitando as características e a história de cada lugar; (d) depois disso surgiu a modalidade de participação através do diálogo, mas ainda ficando as decisões finais nas mãos do profissional, arquiteto, no caso, tendo o modelo do diálogo quatro objetivos. Eram eles: (I) a democratização do planejamento através da informação dos moradores locais sobre a proposta do projeto em estado inicial, (2) o acesso do arquiteto a novos dados sobre os quais trabalhar, através da reação dos moradores, (3) a utilização, pelo arquiteto, de características especiais regionais e (4) como o diálogo se dá numa situação "cara a cara", o não anonimato do usuário nem do arquiteto. Ainda segundo Wulz, uma quinta situação (e) é a alternativa, onde a participação se dá através de representação, então a participação do cliente é ativa, mas não é pessoal - outro o representa. $\bigcirc$ passo seguinte $(f)$ é a co-decisão, onde o diferencial é que o cliente participa individual e pessoalmente, do processo, sendo a última instância (g) a da auto-decisão, onde o cliente resolve por si, prescindindo da participação do arquiteto.

Finalmente para esse autor, a questão-chave diz respeito à participação como método de trabalho, um processo que se desenvolve no tempo e não apenas pontualmente: "A participação como método sempre tem o efeito (mesmo

16 In SANOFF, Henry, 1990. 
que às vezes fraco) de emancipação, um processo educativo e de socialização." ${ }^{17}$ (SANOFF, p. 48) Essa afirmação nos coloca frente a uma posição bastante diferenciada, no que propõe uma nova forma de trabalho, que acredita na construção de conhecimento através da interação entre os atores num processo de projeto participativo. Dessa forma, fazer da participação um método é uma proposta diametralmente oposta a simplesmente convidar a comunidade a dar sugestões, fazer críticas, responder questionários, pois ela implica numa forma relacional de trabalho.

Para outro autor, J. E. Diaz Bordenave, o conceito de participação tem outra classificação:

- $\quad$ informação ou informação/reação

- consulta facultativa

- consulta obrigatória

- $\quad$ elaboração/recomendação

- co-gestão

- delegação

- $\quad$ auto-gestão

E para David Godschalk (GODSCHALK, 1972), outra ainda, divida em duas categorias:

Não participação

- 'Manipulação', para validar ações de comitês consultivos

- 'Terapia', a exemplo de Arnstein, quando cidadãos devem ser 'curados' de alguma patologia através da participação em grupos

- Tokenism ${ }^{18}$

- 'Informação', onde cidadãos são apenas informados sobre seus direitos e suas opções

\footnotetext{
17 "As a method participation always has the effect (if sometimes a weak one) of emancipation, an educative and socialization process."

${ }^{18}$ Ver nota 15.
} 
- 'Consulta', onde as idéias dos cidadãos são solicitadas através de pesquisas, encontros no bairro e audiências públicas

- 'Aplacamento', quando uns poucos representantes dos pobres ou sem poder são colocados em conselhos públicos

Poder do Cidadão

- 'Parceria', onde cidadãos compartilham responsabilidades de planejamento e tomada de decisões através de conselhos e regras decisórias

- 'Poder delegado', no qual os cidadãos têm autoridade dominante sobre a tomada de decisões a respeito de um plano ou programa em particular

- 'Controle pelos cidadãos', onde participantes ou residentes dirigem um programa ou instituição, são responsáveis por políticas públicas e gerenciamento, e podem negociar quaisquer tentativas de mudança por parte de pessoas de fora do programa.

Para finalizar, processos como esses têm, segundo J. Burns ${ }^{19}$, quatro categorias, quatro momentos:

- consciência: as pessoas envolvidas descobrem as realidades de um dado ambiente, de forma que todos falem a mesma linguagem;

- percepção: compreende-se a situação e suas ramificações físicas, sociais, culturais e econômicas, de forma que o entendimento, os objetivos e as expectativas de todos os participantes sejam recursos para o trabalho;

- tomada de decisões: a partir da consciência e da percepção do ambiente, passa-se ao desenho do programa; e

- implementação: um momento muito importante da participação, pela responsabilidade de cada um dos envolvidos no como, aonde, quando e quem, que então devem ser somados ao que as pessoas desejam e à aparência que o projeto terá.

Analisando essa série de classificações de diferentes autores, podemos verificar que existem inúmeras variações do que se considera como graus possíveis

19 In SANOFF, H. "Participatory Design in Focus", in SANOFF, 1990. 
de participação; no entanto, podemos observar uma constante: a escala de níveis de participação varia sempre de situações onde a comunidade e/ou o cliente absolutamente não têm voz, passando por outras que aparentam uma real participação, ou onde há participação parcial, até se chegar à independência da comunidade. Para praticamente todos os autores citados, o nível de participação mais significativo, e com mais qualidade, se dá quando as pessoas têm uma atuação efetiva no processo, com real poder compartilhado de sugestão e decisão; quando não se tomam emprestadas as palavras e/ou a presença de crianças, jovens ou pessoas de algum outro grupo minoritário ou com menos poder, apenas para legitimar suas próprias posições e políticas em questões que dizem respeito a esses grupos, e quando a participação desses grupos não é usada como ferramenta de marketing e de comunicação pelos adultos organizadores do processo.

presente trabalho tem como objetivo refletir sobre formas, possibilidades de trabalho no sentido de capacitar os jovens, oferecer-Ihes oportunidades para que se apropriem de ferramentas e conceitos para a leitura e compreensão de seus lugares de vida, de forma a poderem optar pela participação ou não dos diagnósticos, elaboração de projetos e gestão desses lugares. Sem dúvida, a autonomia e a independência são valores a serem conquistados, e serão enfocados com caráter de relevância em projetos de parceria, colaboração, e construção conjunta de conhecimento sobre as paisagens.

\section{EDUCAÇÃO AMBIENTAL}

( campo da educação ambiental traz uma contribuição nesse sentido, avançando na perspectiva formativa da participação. De acordo com Reigota: "[a] educação ambiental não deve se preocupar em transmitir conhecimentos, mas sim produzir conhecimentos; consideramos que não aprendemos do outro, mas com o outro, criando com ele (...) assim, aumenta o desafio para a educação ambiental de formar cidadãos que possam participar da tomada de decisões sobre assuntos que dizem respeito a grupos sociais e étnicos muito diferentes, geralmente controlados por grupos que dominam a economia e a política, com interesses muito mais 
homogêneos." 20 Podemos transpor essas idéias para esta nossa reflexão: o diálogo pressupõe a troca, a transformação, a criação de novas idéias, o respeito a cada um de seus protagonistas; processos participativos implicam na igualdade de posição de todos os envolvidos de forma a que o conhecimento produzido pelo grupo - seja um levantamento de problemas, seja uma exposição de fotos de um bairro, seja o projeto de uma praça, seja um plano de ocupação de alguma área livre, sejam conceitos a serem aplicados em algum projeto - reflitam as suas idéias, suas decisões, seu consenso, suas dúvidas, seus conflitos.

Como arquitetos paisagistas, lidamos, entre outras, com questões ambientais. E como acreditamos que processos participativos têm, necessariamente um caráter pedagógico, a educação ambiental é uma disciplina que certamente nos diz respeito; ela deve caber em nossa prática. $\bigcirc$ arcabouço de conhecimento específico da nossa área inclui questões relativas a recursos hídricos, vegetação, solo (características, dinâmica, uso e ocupação), ventos, conformação do espaço, sistemas de áreas livres entre tantos outros, uso e ocupação do solo; deveria fazer parte do nosso trabalho o compartilhamento desse conhecimento com a comunidade em geral e, especialmente, com jovens, trabalhando para que ele se tornem cidadãos e cidadãs capazes de participar ativamente, caso assim desejem, das discussões e decisões referentes a esses assuntos.

Quando falamos da importância do conhecimento dos processos que contribuem na conformação de uma paisagem, é certo que existem algumas disciplinas que podem nos auxiliar nessa tarefa - a própria história, a sociologia, a antropologia, entre outras. No entanto, o campo da arquitetura paisagística tem, por sua vez, uma contribuição específica a dar e é disso que se trata este trabalho.

É de fundamental importância o "fortalecimento do espaço público e [a] abertura da gestão pública à participação da Sociedade civil na elaboração de suas políticas públicas; e [a] sempre complexa e contraditória institucionalização de

${ }^{20}$ Reigota in Ostrowsky, p. 38 
práticas participativas inovadoras que marcam rupturas com a dinâmica predominante, ultrapassando as ações de caráter utilitarista e clientelista."21

Para tanto, são necessárias práticas, vivências, experiências que contribuam com a formação de cidadãos participantes. A Educação Ambiental tem muito a contribuir com essa discussão, apesar de não nos caber aqui aprofundarmo-nos na sua definição;mas ela tem fundamental importância na construção do conhecimento relativo aos lugares de vida das pessoas e de como elas se apropriam deles. Muitas das questões ambientais são parte integrante do corpo de conhecimento que o arquiteto paisagista deve dominar, pois quando se lida com espaço, é preciso conhecer seus movimentos no que diz respeito aos processos naturais (dinâmica das águas, processos de regeneração de áreas verdes, de formação de solos, etc.) e sociais (organização de associações de bairro, de cooperativas de geração de renda, ocupação do solo público e privado, etc) que ocorrem nele. A educação ambiental tem um cunho de resistência, de questionamento e o diálogo entre profissionais (o sistema perito ${ }^{22}$ ) e a comunidade (o leigo) fomenta essa resistência e esse questionamento e o arquiteto paisagista tem muito a contribuir nesse processo. Entretanto, dependendo da visão didática mais ou menos emancipatória que tenha o professor (ou responsável por estudos do meio e oficinas), a Educação Ambiental pode se tornar uma instância meramente burocrática e 'bancária' (no sentido que Paulo Freire atribuía à educação de estrita transmissão de conteúdos).

Para Anthony Giddens, "[o]s sistemas peritos ... removem as relações sociais das imediações do contexto". (GIDDENS, 199I) Para esse autor, o leigo confia nos sistemas peritos sem possuir o seu conhecimento - anda-se de avião, por exemplo, sem no entanto saber como ele se mantém no ar. Sem isso, a sociedade pósmoderna não funcionaria - andamos de carro, utilizamos a água que nos é fornecida pela concessionária paulista SABESP, e assim por diante. Numa situação de processo de projeto para áreas livres isso significa que, caso o leigo não se envolva na ação, ela simplesmente confia - confia em que árvores são algo de bom

\footnotetext{
${ }^{21}$ Pedro Jacobi, no texto "Políticas sociais locais e os desafios da participação citadina", de 200 I.

${ }^{22}$ Sobre isso ver GIDDENS, 1991.
} 
e que não vão cair na cabeça delas, que uma área precisa ser cercada, que o parquinho é seguro para as crianças, por exemplo. Ou não confia...

Muitos de nossos espaços livres não têm sido exemplos de algo que funcione bem. Vemos nossos rios e córregos completamente descaracterizados como tal, praças abandonadas, parquinhos infantis depredados, áreas livres sem uso ou mal utilizadas, e outras situações que nos mostram que, neste caso, não há condições para que se estabeleça confiança, pois o sistema perito não demonstra competência. Isto abre um enorme campo de atuação para projetos participativos, onde há negociação e pacto; a partir daí podem surgir notáveis e surpreendentes soluções, e a cidade é um campo de negociação por excelência.

\section{UM GIRO PELO MUNDO}

Falaremos a seguir, brevemente, sobre alguns projetos urbanos participativos que nos mostram que este assunto está sendo discutido e trabalhado não só no Brasil, mas também em muitas cidades ao redor do mundo. São grupos da sociedade civil, como $O \mathrm{NGs}^{23}$, $\mathrm{OSCIP}^{24}$ s, e associações diversas, que propõem ações ora semelhantes, ora distintas, mas com preocupações similares de promover a participação da comunidade - inclusive crianças e jovens - em discussões, ações, intervenções, instalações, reestruturações, transformações do espaço público.

Todos esses trabalhos têm contribuições a nos oferecer, cada um com sua especificidade.

\section{Projeto Bacias Irmãs ${ }^{25}$}

"O projeto Bacias Irmãs surgiu de uma parceria firmada entre a Universidade de São Paulo - CECAE ${ }^{26}, \mathrm{ESALQ}^{27}$ e $\mathrm{PROCAM}^{28}$-, a Faculdade de

${ }^{23}$ ONG - Organização não Governamental

24 OSCIP - Organização da Sociedade Civil de Interesse Público

${ }^{25}$ Minha participação nesse projeto se deu através do intercâmbio, em Toronto, e da participação em uma publicação (em andamento) sobre as ações de educação ambiental na Bacia do Córrego Pirajussara, uma das bacias hidrográficas que fazem parte do projeto. As outras duas são a do Black Creek, em Toronto, e do Piracicamirim, em Piracicaba. 
Estudos Ambientais da Universidade de York - FES, no Canadá e o Instituto Ecoar para Cidadania, em meados de 2003, com recursos da Canadian International Development Agency - CIDA. ${ }^{29}$

Seu principal objetivo é o de "fortalecer a capacidade das entidades envolvidas em construir parcerias com a sociedade civil e desenvolver metodologias inovadoras que estimulem a participação popular nas instâncias de decisão das políticas públicas ambientais, contribuindo assim, para o aperfeiçoamento e democratização do gerenciamento dos recursos hídricos no Brasil."’30

Alguns outros objetivos são:

- "desenvolver e experimentar uma metodologia educacional dirigida ao fortalecimento da participação da sociedade civil na gestão compartilhada de recursos hídricos;

- "fortalecer a capacidade da sociedade civil de duas bacias hidrográficas (pilotos), para a articulação e a efetiva participação nos processos de tomada de decisão relacionados à gestão de recursos hídricos em cada uma delas, incluindo a capacidade de propor e desenvolver projetos baseados em princípios da sustentabilidade sócio-ambiental;

- "desenvolver técnicas, métodos e materiais pedagógicos inovadores na área de recursos hídricos, passíveis de serem utilizadas por diferentes instituições em diferentes processos educacionais ou instrucionais, incluindo diferentes mídias;

- "experimentar e desenvolver ferramentas e recursos pedagógicos."31

O projeto tem 3 fases distintas:

- "a primeira, direcionada ao mapeamento geográfico, demográfico, sócio-econômico e institucional das bacias;

${ }^{26}$ Coordenadoria Executiva de Cooperação Universitária e de Atividades Especiais

${ }^{27}$ Escola de Agronomia Luiz de Queiroz

${ }^{28}$ Programa de Ciências Ambientais

${ }^{29}$ Do site www.baciasirmas.org.br acessado em 30 de agosto de 2006

${ }^{30}$ Idem

${ }^{31}$ Idem 
- "a segunda, direcionada à implantação do programa de Educação Ambiental subdividido em quatro etapas - o diagnóstico sócioambiental participativo, a formação de multiplicadores, o processo de projeto participativo de um plano de ação, e, a criação de uma rede de sustentabilidade futura; e

- "a terceira, que deverá acontecer durante todo o projeto (em paralelo às fases anteriores), direcionada à documentação e registro de todos os dados passíveis de serem analisados em um momento final de conclusão da pesquisa." 32

A segunda fase desse projeto tem seu foco em trabalhos participativos que incluem oficinas de educação ambiental. Os participantes dessas oficinas são fundamentalmente alunos de escolas da região da Bacia do Pirajussara. Há objetivos coincidentes, nessa fase do trabalho, com algumas idéias de participação que apresentamos anteriormente: a importância da capacitação da população para compreender aspectos e a dinâmica da paisagem de seus lugares de vida, nesse caso, no que diz respeito especificamente aos recursos hídricos; a importância de processos participativos na construção da cidadania, entre outros.

Nesse contexto, podemos citar ainda um outro projeto de Educação Ambiental: uma parceria entre duas comunidades (S. Carlos, SP, Brasil e Córdoba, Córdoba, Argentina) e duas universidades (Universidade de S. Paulo e Universidade Nacional de Córdoba) para o estudo de bacias hidrográficas locais, junto às escolas. Tal como no Projeto Bacias Irmãs, buscou-se "...levar o indivíduo a repensar sua relação com o meio, de forma a garantir mudanças de atitudes em prol da melhoria da qualidade da sociedade na qual está inserido...". (SCHIEL, 2002: I8)

\section{Uma Fruta no Quintal}

O Projeto Uma Fruta no Quintal, apresentado e discutido por Raul Pereira em sua tese de doutorado ${ }^{33}$, foi desenvolvido no município de Diadema, na década de 90. Inicialmente, "...pretendia-se trabalhar paisagisticamente os espaços livres da escola, de forma a envolver todas as disciplinas, com o intuito de levantar questões

\footnotetext{
${ }^{32}$ Idem

33 PEREIRA, 2006.
} 
relativas ao ambiente e ao uso dos espaços físicos escolares e, a partir daí, extrapolar para ações e discussões sobre as demais áreas livres publicas da cidade." (PEREIRA, 2006: I 16) Os objetivos eram baseados em propostas de diálogo, troca de saberes, conhecimento do ambiente (todos seus aspectos), valorização da diversidade (social e biológica), com ênfase na reflexão, e com vias à formação de professores e alunos.

Essas questões não são exclusivas do 'Uma Fruta no Quintal'; elas têm permeado outros projetos, tendo sido tema de discussão em várias partes do mundo. Em Ankara, por exemplo, foi desenvolvido um projeto - 'I 000 Arquitetos em 1000 Escolas $^{\prime 34}$ - com preocupações similares. $\bigcirc$ projeto aproxima arquitetos a crianças e jovens para discutir questões da cidade, pensar os espaços urbanos, tendo escolas como núcleos aglutinadores.

\section{Praça em frente a um colégio}

objeto de trabalho descrito a seguir é uma pequena praça pública (na esquina das ruas Vitorino de Carvalho e Nazaré Paulista), em frente a uma escola privada de classe média alta, na cidade de São Paulo. ${ }^{35}$

Por iniciativa e sugestão de um pai arquiteto, a escola aceitou liderar um grupo de trabalho para desenvolver o projeto e implantação da referida praça, que era utilizada pelos alunos em horário de recreio. $\bigcirc$ local tinha também como freqüentadores assíduos um grupo de senhores que lá jogavam damas e os motoristas de um ponto de táxi; havia também uma banca de jornais.

Organizaram-se três sub-grupos: projeto, relações jurídicas e captação de recursos. $\bigcirc$ grupo encarregado de elaborar o projeto era formado por seis arquitetos e arquitetas. Com o objetivo de envolver os alunos da escola, com a participação deles foi elaborado e aplicado um questionário para moradores do

\footnotetext{
${ }^{34}$ Comentaremos outros aspectos deste projeto mais adiante.

${ }^{35}$ As informações nos foram fornecidas pela arquiteta paisagista Cecilia Gorski, mãe de um aluno e integrante do grupo de projeto.
} 
entorno. As respostas variaram de negativas à participação - "já pagamos impostos, não temos nada a ver com isso", "a prefeitura é quem tem que cuidar disso" - até sugestões do que colocar no local - "lugar pra sentar", "sombra". As classes trabalharam na preparação de uma campanha pela praça, fazendo camisetas para serem vendidas e organizando uma festa na própria praça para divulgar a idéia.

O projeto foi elaborado pelo sub-grupo de arquitetos, que levaram em consideração sugestões e demandas apresentadas pelos alunos em algumas consultas feitas a eles, e por alguns moradores. Foram acrescidos também elementos não solicitados pelos alunos, como por exemplo uma elevação no piso de mais ou menos $80 \mathrm{~cm}$ de altura; esse elemento foi contestado numa das discussões do projeto com alunos, pais e professores, mas depois se mostrou um forte ponto de aglutinação dos jovens. $\bigcirc$ resultado final foi apresentado à comunidade durante esta festa, na forma de uma maquete. A idéia da maquete surgiu devido ao fato dela ser uma forma de apresentação mais clara e compreensível para leigos. Plantas baixas, cortes e vistas não seriam de compreensão tão fácil quanto um modelo em escala, embora o repertório de representação gráfica do arquiteto possa (e deva) no processo ser absorvido, apreendido.

Criou-se um elemento de piso que pudesse contemplar a participação dos alunos: uma faixa no piso que receberia mosaicos feitos por eles. Esses mosaicos foram preparados em sala de aula, nas aulas de artes e depois aplicados no piso.

Um fator fundamental para que esse processo alcançasse seu objetivo foi o fato de a diretoria da escola assumir a liderança. A diretoria da escola funcionou como uma locomotiva, garantindo a continuidade dos trabalhos em momentos de maior dificuldade.

\section{Planos Diretores dos Municípios de São José e Itajaí}

A partir das diretrizes do Estatuto da Cidade e de determinações do Ministério das Cidades, assim como muitos outros, os municípios de São José 
(Grande Florianópolis) e de Itajaí (Santa Catarina) procuraram envolver a população nos processos de elaboração dos seus planos diretores. No entanto,

“...a participação da população no processo de elaboração do Plano Diretor [de São José] ainda é bastante limitada. O processo participativo esteve limitado à etapa do processo de leitura comunitária, onde foram organizadas muitas reuniões com a participação da comunidade onde a população foi orientada a apresentar os seus 'problemas', sendo limitadas as apresentações de 'idéias' ou 'soluções'. A população não teve acesso ao levantamento das informações sobre o município elaborados pelos técnicos, ou seja, da leitura técnica da cidade. A participação esteve limitada a reivindicações da população a partir de suas vivências cotidianas. Associar democratização da informação com a percepção da população sobre o lugar onde vivem parece ser ainda o grande desafio para qualificar o processo participativo...

"A experiência de elaboração de Plano Diretor Participativo no Município de Itajaí, litoral de Santa Catarina procurou fazer um investimento maior na etapa de leitura comunitária, buscando um envolvimento maior da população através de um trabalho preparatório com os estudantes das escolas públicas municipais, mas ainda reconhecendo muitas dificuldades neste processo. Segundo depoimento de um técnico sobre a importância da leitura comunitária no processo de elaboração do plano diretor participativo, ele afirma que a leitura comunitária traz informação e um olhar diferente do técnico, traz um olhar com a preocupação de quem vivencia o lugar que está sendo pensado. Aparece na leitura comunitária a preocupação com os espaços públicos, praças, áreas de lazer, e outros." ${ }^{36}$

Estes dois exemplos nos mostram como a participação da população em questões relativas aos seus lugares de vida tem estado presente nas discussões sobre as cidades e como ela foi estimulada pelo Estatuto da Cidade, que the deu legitimidade. E indicam, ao mesmo tempo, como essa prática ainda é incipiente no Brasil, sendo preciso refletir sobre ela, propor novas ações, experimentar, avaliar resultados para que possamos construir um corpo de conhecimentos que nos

\footnotetext{
${ }^{36}$ Idem nota 5
} 
permita avançar nesse campo.

\section{Project for Public Spaces ${ }^{37}$}

Essa é uma organização sem fins lucrativos americana que se dedica a criar e apoiar espaços públicos que contribuam para a sustentabilidade de comunidades, oferecendo assistência técnica, treinamento, pesquisa e outros serviços. Desde sua fundação, em 1975, esse grupo já trabalhou em mais de 1.500 comunidades nos Estados Unidos e ao redor do mundo, apoiando grupos de pessoas na transformação de seus espaços públicos em lugares vitais para sua comunidade. É um grupo que se dedica a 'criar bons lugares'. Para eles, a comunidade é o especialista; os moradores, trabalhadores e freqüentadores de um lugar oferecem uma visão importante sobre como os lugares funcionam, e têm uma compreensão única das questões que são fundamentais. Em um documento ${ }^{38}$ onde discutem o uso privado/comercial de espaços públicos encontrei este texto:

"As melhores atividades comerciais em espaços públicos não são uma rua de mão única - os usuários devem se sentir parte da ação. Quando as pessoas têm a chance de participar, mesmo de forma limitada tal como conversar com produtores locais numa feira de fazendeiros, isso faz com que saibam que são mais do que continentes de consumo. Por outro lado, absorver passivamente um anúncio da Jumbotron no lançamento da NFL ${ }^{39}$ deixa-os de fora, sem qualquer ligação pessoal com os eventos que acontecem à sua volta... A atividade comercial participativa pode ser enganadora, mas quando bem feita é extremamente gratificante. As pessoas sabem que um lugar é seu quando elas são parte ativa do que acontece."

\footnotetext{
37 'Projeto para Espaços Públicos' - www.pps.org

38 Do site, acessado em 18/10/2006

39 Jumbotron é uma tela de vídeo gigante; NFL, é a National Football League (Liga Nacional de Futebol).
} 
Neste caso há um forte viés tendencioso no sentido do uso da participação apenas para a validação de atividades comerciais; podemos, no entanto verificar como a participação tem se tornado parte integrante do discurso sobre espaços públicos, o que denota o crescimento de sua importância na vida das pessoas; é uma sinalização do valor que se tem atribuído à questão.

É preciso deixar claro o tipo de participação que se considera realmente transformador, mas não podemos deixar de notar como cada vez mais o assunto "participação" está presente nas discussões a respeito das cidades.

\section{Esterni $^{40}$}

Esterni é um grupo de arquitetos italianos que desenvolve "um projeto sócio-cultural de amplo alcance; um movimento que estimula análises, idéias e eventos; um ideal de participação que recebe pessoas para que expressem sua individualidade; um grupo de trabalho que pensa e age para provocar transformações reais. Esterni está envolvido com diferentes ramos da cultura, arte e comunicação; ele impulsiona a interação social e apóia o uso de espaços públicos a real herança da comunidade."

O grupo propõe a participação da população na transformação dos espaços públicos de sua cidade, através de atividades variadas propostas por eles. $\bigcirc$ uso da arte é em suas propostas é um de seus aspectos essenciais.

\section{TerritorioSur ${ }^{42}$}

Este outro grupo, de Valparaiso, no Chile, tem objetivos similares. Sua apresentação coincide com o que entendemos como uma de nossas funções como profissionais na sociedade:

\footnotetext{
40

www.esterni.org

${ }^{41}$ do site, acessado em 01/03/2007 (grifo nosso)

${ }^{42}$ www.territoriosur.org
} 
"Nossa organização, criada em 200 I, se constitui de uma equipe multidisciplinar de profissionais comprometidos com a sustentabilidade política, ecológica, social e econômica dos habitats e suas comunidades humanas, do Chile e da Região Latinoamericana.

"Cremos no desenvolvimento humano, sócio-econômico, político, cultural, tecnológico e ambiental sustentável como alternativa de crescimento para nossa sociedade, um desenvolvimento na escala humana, onde os cidadãos/ãs são atores protagonistas e importantes, um desenvolvimento centrado no bem estar geral das gerações presentes e futuras, um desenvolvimento apropriado que é gerado e se fortalece a partir da nossa história, cultura e identidade. Como equipe profissional estamos comprometidos com o fortalecimento da sociedade civil através da transferência de nossos saberes e capacidades a grupos, organizações sociais, comunidades e unidades territoriais de nível local, municipal e regional, privilegiando a conformação de alianças estratégicas associativas em função da consecução de objetivos comuns de desenvolvimento sustentável em uma perspectiva de integralidade. A partir deste cenário aspiramos estabelecer uma relação mais inovadora e legítima com o Estado, com vistas à promoção criativa, ampla e efetiva da participação cidadã e o aprofundamento dos canais da democracia. Nos definimos jurídica e ideologicamente como uma Cooperativa de Trabalho considerando que nos comprometemos com o princípio da cooperação e solidariedade com a natureza e as pessoas. Cremos que a relação de trabalho mais justa e sustentável é a da participação e da cooperação, onde cada um de nós colabora com aquilo de que é mais capaz e hábil, em uma rede de interdependência direcionada para o alcance de objetivos comuns." ${ }^{43}$

Este grupo é formado por uma assistente social, um profissional licenciado em história e geografia, um engenheiro civil bio-químico, um professor de filosofia, um engenheiro ambiental e um arquiteto.

43 os 4 grifos desta citação são nossos 
Alguns aspectos em sua apresentação nos chamaram a atenção, por coincidir com algumas de nossas premissas: a interdisciplinaridade, a intenção de "transferir... saberes e capacidades", o protagonismo dos cidadãos, o desejo de trabalhar em parceria com o poder público, a preocupação com a equidade, a justiça, e a sustentabilidade ${ }^{44}$, a valorização do saber de cada um.

\section{$C Y E^{45}$ - Crianças, Jovens e Ambiente}

Na Universidade do Colorado existe, desde 2004, esse centro de Pesquisa e Design, ligado à Faculdade de Arquitetura e Planejamento. O grupo procura "a vanguarda nas profissões de design e afins no sentido de promover a saúde, a segurança e o bem estar de crianças e jovens. Trabalhando em colaboração com parceiros junto à comunidade, o CYE apóia a participação significativa de jovens na criação de comunidades bem-sucedidas para todos. $\bigcirc$ Centro desenvolve atividades interdisciplinares em pesquisa, ensino e extensão, conectando os mundos da pesquisa, das políticas e da prática com os ambientes onde vivem os jovens. foco é particularmente dado sobre crianças e jovens em ambientes desfavoráveis e aqueles com necessidades especiais. ${ }^{46}$

As crianças e jovens são considerados não apenas como alvo das ações mas, concomitantemente, como parceiros na identificação de problemas que os atingem e na criação de soluções para eles.

${ }^{44}$ Sustentabilidade - conceito discutível, mas aqui considerado como a proposta de "ser um meio de configurar a civilização e atividade humanas, de tal forma que a sociedade, seus membros e suas economias possam preencher suas necessidades e expressar seu maior potencial no presente, e ao mesmo tempo preservar a biodiversidade e os ecossistemas naturais, planejando e agindo de forma a atingir pró-eficiência na manutenção indefinida desses ideais." (Wikipedia)

45 "Children, Youth and Environment"

${ }^{46}$ O Centro também funciona como Escritório do Periódico do CYE, uma publicação independente, fonte importante de artigos sobre pesquisas autorizadas, resenhas aprofundadas, relatórios de campo desafiadores, resenhas criticas de livros e as mais recentes notícias sobre crianças, jovens e seus ambientes. 


\section{Architects in 1000 Schools $^{47}$}

Este é um programa que se desenvolve em Ankara, na Turquia, desde 2002, como parte do projeto 'Crianças e Arquitetura'; é uma parceria da Câmara de Arquitetos da cidade com o Centro de Pesquisas em Cultura Infantil da Universidade de Ankara. Seu objetivo é apresentar aos jovens os principais conceitos da arquitetura, mas ele tem como meta mais ampla "tornar as cidades mais compreensíveis e previsíveis para crianças e jovens, como evolução de seu direito de viver em lugares mais amigáveis." ${ }^{48}$ As propostas de atividades incluem, entre outras, oficinas de maquetes de representação da 'cidade dos sonhos', de uma cidade descrita por Ítalo Calvino, no livro "Cidades Invisíveis", oficinas de modelagem em argila e de construção de abrigos para o sol e a água; crianças e jovens de escolas e realidades distintas são postas juntas para trabalhar nas propostas; a discussão acerca dos problemas da cidade, o diálogo para elaborar idéias referentes ao que se está debatendo, a interação e troca de saberes é incentivada, valorizando a diversidade. "Este processo de olhar criticamente e dar respostas a seus ambientes ajuda as crianças a se tornarem cidadãos responsáveis." ${ }^{49}$

\section{Erdington, Inglaterra}

Esta experiência descrita em Adams e Inghams (1998) diz respeito a um projeto do Conselho Municipal de Birmingham para o Plano de Ação Local de Erdington, na Inglaterra. A comunidade foi envolvida no projeto através de um grupo de jovens, e diz sobre esse projeto o diretor do Departamento de Planejamento e Arquitetura: "É importante não apenas para as crianças compreender a história à sua volta, mas também começar a entender como seu meio é administrado, quais forças existem que estão tentando mudá-lo, e como as

\footnotetext{
47 "Mil Arquitetos em Mil Escolas"

48 in SENER, Tulin (2006). "The Children and Architecture Project in Turkey." Children, Youth and Environments I6(2): 191-206. Obtido em 01/05/2007 do site http://www.colorado.edu/journals/cye

${ }^{49}$ Idem
} 
pessoas, através do governo, podem controlar essas pressões e direcioná-las de uma forma benéfica. Como planejadores do governo local, precisamos de um público educado para se interessar pelo que está acontecendo." 50 "Um dos objetivos do projeto ... era encorajar e capacitar jovens a participar na determinação de uma agenda, proceder a um trabalho de pesquisa, explorar questões ambientais e fazer propostas." ${ }^{\prime \prime}$ Num certo momento desse projeto houve uma discussão sobre materiais de construção e a questão da acessibilidade universal e essa discussão envolveu os jovens e seis arquitetos e planejadores e um deles avaliou o processo: "O projeto com a Osborne School foi mutuamente gratificante. Assim como as crianças aprenderam sobre planejamento urbano, nós como departamento aprendemos quais mudanças nossos mais jovens cidadãos gostariam de ver no seu bairro." Nesse caso houve uma transformação na realidade. As crianças incorporaram muitos conhecimentos acerca da cidade e de como ela pode ser transformada; conhecimentos estes que certamente contribuíram para a construção da cidadania. Esse aprendizado só se deu porque as crianças foram realmente envolvidas no processo desde a percepção do ambiente até a proposição de mudanças.

\section{$\star * *$}

A menção a esses grupos e projetos serve para mostrar que o caminho que estamos procurando trilhar não é absolutamente novo, mas vem sendo desenhado, construído, experimentado, trilhado, por um grande número de pessoas ao redor do mundo. Todos esses trabalhos têm, ao mesmo tempo, características bastante distintas e diretrizes muito similares; eles devem servir não apenas como fonte de consulta, mas também como um incentivo àqueles dedicados a pensar sobre essas questões, preocupações, interesses e idéias. Certamente existem muitos outros grupos trabalhando nessa área, mas optamos por citar apenas alguns para exemplificar possibilidades distintas de atuação, que podem servir como referências e/ou canais de interlocução.

\footnotetext{
50 "Changing Places", de Eileen Adams e Sue Ingham.

${ }^{51}$ Idem
} 


\section{OS PARTICIPANTES}

Projetos participativos podem ter atores bastante diversos. A idéia de participação cidadã deveria congregar, a rigor, todos os setores da sociedade, o que inclui: o Estado, a sociedade civil, o mercado e o terceiro setor. A Universidade pública tem, nesse universo, um papel fundamental, específico. Na medida em que uma de suas funções precípuas é a produção de conhecimento, deve participar de processos no espaço público mantendo seu caráter autônomo, crítico e nesse sentido, privilegiado. Por outro lado, trata-se de uma instituição educacional, comprometida com a socialização do conhecimento. Portanto, uma vez que se constitua como um dos atores de processos participativos no espaço público, deve fazê-lo de forma pedagógica, identificando formas transversais de atuação o que pode envolver parcerias com escolas, ONGs e outras associações, e alimentando atividades de extensão universitária junto à comunidade.

"As ações conjuntas da universidade e dos educadores locais têm como meta a formação de cidadãos e profissionais capacitados para atuar em processos de projetos e gestões participativas." 52 Aqui Gonçalves fala da importância da atuação conjunta de universidades e escolas locais. As escolas podem ser atores fundamentais porque reúnem crianças, jovens, professores/as, funcionários/as, pais e mães. Segundo Raul Pereira, "[o]s espaços escolares possuem a capacidade inesgotável de possibilitar a criação de formas de socialização e, por conseguinte, a nossa auto-referenciação no mundo, através do exercício comparativo entre as diferentes práticas e pontos de vista sociais. ... Como instância promotora e legitimadora de práticas sociais coletivas e solidárias, a escola pode também promover meios de reflexão que remetem a uma outra dimensão do tempo, o ritmo lento, mais propenso a um tipo de acuidade que toda investigação mais profunda requer, servindo como contraponto ao tempo mais veloz e atropelante da mídia e dos discursos opacos. Apenas isso já valida a escola como local bastante

\footnotetext{
${ }^{52}$ Idem nota 6 (p. 126)
} 
propício a atividades de natureza participativa." 53 As escolas, fontes de formação e de produção de conhecimento, são talvez atualmente os mais legítimos canais a serem utilizados para trabalhos participativos de leitura e entendimento da cidade. (SCHIEL, 2002)

Quando tratamos de espaços urbanos livres públicos devemos considerar o Estado como ator importante em projetos participativos, já que ele detém o poder de executar planos e projetos para áreas livres públicas. Quanto à competência legal ele é, assim como são os cidadãos, responsável por isso. No entanto, muitas vezes os projetos não contam com o Estado, e nesse caso existe uma questão de fundamental importância: a necessidade de explicitação, para todos os participantes, do caráter desses trabalhos. Há que se ter cuidado para não se criar expectativas que não possam ser satisfeitas quanto aos resultados dos trabalhos, deixando claro nosso propósito ao nos envolvermos com o processo. Comunidades carentes em especial são muito procuradas como objeto de estudo; é fundamental que a parceria com elas seja estabelecida logo no início dos trabalhos, desde o acordo de participação, passando pela definição de objetivos até a avaliação dos resultados. No projeto Uma Fruta no Quintal, que será comentado no Capítulo 2, ao proporem que crianças desenhassem seus sonhos para o espaço livre de sua escola, os profissionais informavam-Ihes que haveria restrições orçamentárias para a execução dessas propostas. "Essa informação era importante e tinha como objetivo não criar falsas expectativas nos alunos e professores..." (PEREIRA, 2006: I46) É fundamental que haja interesses consensuais e ganhos legítimos para todos os envolvidos.

ONGs e outras associações também podem participar desses processos na medida em que sejam representantes de algum grupo da comunidade. A participação de grupos e pessoas com diferentes bagagens, diferentes habilidades e capacidades, diferentes histórias, diferentes objetivos, amplia a diversidade no

\footnotetext{
53 in "O Sentido da Paisagem e a Paisagem Consentida" - Tese de Doutorado defendida na FAU USP em 2007.
} 
diálogo, o que enriquece o processo e seu produto. É do diálogo e da negociação que vão surgir novos sonhos, novas idéias, novas propostas.

\section{PAPEL DO ARQUITETO PAISAGISTA}

Como arquitetos paisagistas, procuramos refletir sobre nosso papel na construção e transformação das cidades, através de processos participativos.

Seguem-se duas citações de um livro que apesar de tratar de educação préescolar, têm uma ligação bastante estreita com o processo de construção de cidadania. A primeira é de Ana Mae Barbosa, no prefácio: “...suas aulas são um jogo contínuo entre a imaginação e a percepção. É preciso ver o que está no meio ambiente. Você estimula a imaginação das crianças para descobrirem o que querem e como querem o seu mundo exterior." (FREIRE, 1983: 12) A segunda é da própria autora, na introdução: "Quando se tira da criança a possibilidade de conhecer este ou aquele aspecto da realidade, na verdade se está alienando-a da sua capacidade de construir o seu conhecimento. Porque o ato de conhecer é tão vital como comer ou dormir, e eu não posso comer ou dormir por alguém. A escola em geral tem esta prática, a de que o conhecimento pode ser doado, impedindo que a criança e, também os professores o construam. Só assim a busca do conhecimento não é preparação para nada, e sim VIDA, aqui e agora. E é esta vida que precisa ser resgatada pela escola. Muito temos que caminhar para isso, mas é no hoje que vamos viabilizando esse sonho de amanhã." (FREIRE, 1983: 15)

Para ser um cidadão conhecedor de sua cidade é preciso compreendê-la, ter acesso a ela, a seus lugares, de forma a poder transformá-la na direção que se queira, na direção do sonho de amanhã.

As cidades brasileiras vivem hoje um momento muito conflituoso e de alta complexidade. $\bigcirc$ caminho para a compreensão da complexidade, e o encaminhamento dos conflitos passa necessariamente pelo trabalho de equipes multidisciplinares envolvidas em projetos participativos que envolvam profissionais, por sua capacidade técnica e a população, por ser a personagem principal desses 
processos, pois é ela que vive nas cidades, que sofre com seus problemas e que tem o direito de, e deve contribuir para suas soluções.

Com o intuito de melhor compreender a proposta de refletir sobre o profissional arquiteto paisagista em projetos participativos, vamos traçar um paralelo entre o papel do educador e o do arquiteto em processos dessa natureza, uma vez que a atuação do arquiteto paisagista tem uma importante dimensão pedagógica. A paisagem possui uma visibilidade ímpar; as ações humanas nela se espelham e o arquiteto paisagista elabora produtos plenos de significado, que dela farão parte. Dessa forma, a paisagem fornece uma base informacional, de repertório, e até mesmo ideológica, na medida em que é resultado dos processos humanos sobre a base biofísica. Portanto, o trabalho do arquiteto paisagista na criação de espaços livres públicos pode contribuir criando referenciais importantes, propondo novas relações e respondendo às questões sócio-ambientais do seu tempo. Na medida em que tais produtos sejam resultado de processos participativos, serão elementos constitutivos de dinâmicas de ensino/aprendizagem.

Uma outra questão pertinente faz parte da prática tanto do professor quanto do arquiteto - a legibilidade. "Transformar aquilo que a um profissional com experiência pode parecer óbvio e intuitivo num processo do qual se conhecem as razões e o faseamento de vários caminhos de intervenção possíveis parece-me constituir o principal papel do docente..." (MAGALHÃES, 200 I : 29) Isso diz respeito ao papel do professor, mas, considerando a dimensão pedagógica do trabalho ao qual estamos nos propondo, amolda-se perfeitamente ao papel do arquiteto paisagista. Uma de nossas responsabilidades é projetar espaços urbanos livres públicos. Cabe a nós traduzir para uma linguagem compreensível ao leigo nossas propostas, cabe a nós transformar nosso conhecimento em matéria passível de ser deglutida e processada por ele e, ao mesmo tempo, compreender suas demandas, sonhos e desejos, de forma a favorecer o estabelecimento de um diálogo construtivo e transformador.

No momento em que uma obra possibilita uma real transformação da realidade, mesmo que num âmbito restrito, ela provoca modificações nas relações 
entre os vários elementos dessa realidade. E nesse sentido, o papel do arquiteto paisagista é político.

“Também equivalente à política é a interferência da obra produzida na realidade social, dado que, em certa medida, a altera. Não na acepção em que o determinismo arquitetural, defendido pelo modernismo, acreditou, como solução bastante para originar um novo modelo de sociedade, mas naquilo em que o objeto arquitetônico pode contribuir para sugerir ou permitir uma nova utilização do espaço, criando ou valorizando significados que the estejam associados, ou seja, produzindo pequenos efeitos significativos para as pessoas, mesmo sem a garantia ou a perspectiva de estes contribuírem para a utopia, em que os idealistas dos anos 60 acreditavam." (MAGALHÃES, 2001 : 33)

Uma ação política, segundo Hanna Arendt, é aquela que é acontecimento, é começo, que interrompe processos automáticos, é atividade de criação, de experimentação. Nesse sentido uma ação sobre o espaço público que faz pensar, que faz refletir, que incita à transformação, é uma ação política. (ORTEGA, 2000)

Robert M. Pechman ${ }^{54}$, estabelece um paralelo curioso e crítico entre o urbanista e o detetive, que nos permite algumas reflexões sobre nosso papel político junto à sociedade, pois o urbanista, assim como o arquiteto paisagista, tem como objeto de trabalho a cidade. Seguem alguns trechos que estabelecem esse paralelo:

"Detetive e urbanista serão chamados... a restituir a ordem da cidade e a desfazer seus imbróglios, tornando-a transparente e linear, de forma que nem o 'criminoso nato' pudesse se esconder nas suas sombras e nem suas formas fossem mais convidativas às práticas 'ilegais'." (PECHMAN, 2002: 386)

A cidade e seus enigmas são objetos de nosso trabalho. $\bigcirc$ urbanista anteriormente descrito tem como diretriz a especialização das áreas urbanas; ele busca com seu desenho simplificar a trama urbana.

${ }^{54}$ R. Pechman é historiador, professor adjunto da Universidade Federal do Rio de Janeiro. 
"Para o urbanista que quer abolir a multidão, desatravancar a rua, desmanchar o labirinto e estender por sobre a cidade um manto liso e sem rugas, a cidade como ela é, é inaceitável. $\bigcirc$ urbanista não suporta tal cidade, odeia tal desordem e, por isso, interfere na cidade, muda seu destino, operando na direção de suprimir sua dimensão histórica, dandoIhe um outro sentido: o do urbano." (PECHMAN, 2002: 386)

Esse autor critica fortemente aqui um urbanista totalmente desvinculado das questões sociais, absolutamente alienado das questões vernaculares, inerentes e referentes ao lugar. Este seria um sujeito absolutamente avesso às transformações reais; e seus objetivos, puramente técnicos e ideais. Ele critica também, de certa forma, a busca da descomplicação, do 'esclarecimento' reduzido da riqueza da cidade em detrimento da busca de compreensão do emaranhado, do labirinto, da desordem, do enigma, da sinuosidade. Parte da riqueza da cidade encontra-se aí, na 'polissemia', e é isso que pode tornar muito instigante o trabalho de leitura de uma paisagem urbana. Nada mais tedioso do que a falta de mistérios, a ausência de desafios.

Mais adiante no mesmo livro, Pechman diz que "...o urbanismo que aqui [no Brasil] aportou veio aleijado de sua parte mais nobre...aquela que implementava a cidadania e legitimava o direito do trabalhador à cidade". "Formou-se aqui um urbanismo disciplinador, normatizador, regulamentador, que faz cidades, mas não produz cidadãos." Se por um lado o urbanismo brasileiro pretendeu exercitar esse caráter regulamentador, os processos sociais avassaladores da nossa realidade acabaram produzindo cidades muito complexas e indisciplinadas; esta contradição sugere então um campo muito desafiador e instigante para trabalhos participativos de leitura de paisagens e elaboração de propostas para sua transformação. A leitura dessas nossas paisagens, por sua complexidade propicia uma infinidade de aproximações, oferecendo uma infinidade de possibilidades.

O elemento novo do trabalho participativo é então "...o resgate do sujeito, enquanto campo de possibilidades no pensar e fazer a cidade. Existe uma relação entre o fortalecimento do processo participativo no planejamento e na gestão urbana e a construção dos 
espaços públicos e da urbanidade que acontece a partir do resgate do sujeito. A herança que o urbanismo moderno nos deixou esteve marcada por uma prática de planejamento urbano orientada pela racionalidade disciplinadora e pela negação do sujeito no pensar e fazer a cidade. $O$ processo participativo cria a possibilidade do resgate desse sujeito que se fortalece e se impõe no pensar a cidade, o sujeito que dá sentido aos espaços públicos e os constitui enquanto espaços de vida pública." 55

É aí que reside o interesse deste trabalho: (I) na reflexão sobre formas de contribuição para a formação de cidadãos conscientes, capazes de ter ingerência sobre os processos de produção da cidade; (2) na compreensão do papel de arquitetos paisagistas nesse processo; e (3) na discussão de práticas que possam contribuir com essa formação. Como profissionais assemelhados aos urbanistas ou, que têm um objeto de estudo similar - a cidade/a paisagem - podemos nos atribuir a função de buscar 'implementar a cidadania e legitimar o direito do trabalhador à cidade'.

No que diz respeito à pratica de leitura de paisagens urbanas, o grupo situacionista ${ }^{56}$ tem contribuições a nos oferecer, podendo ser uma inspiração. Suas propostas eram produtos de críticas ao urbanismo funcionalista da época. Eles afirmavam que "quando os habitantes passassem de simples espectadores a construtores, transformadores e 'vivenciadores' de seus próprios espaços, isso sim impediria qualquer tipo de espetacularização urbana." É ainda deles a idéia de que o cotidiano "...seria a fronteira onde nasce a alienação mas onde também pode crescer a participação." (JACQUES, 2003) No cotidiano instala-se o hábito, que é a desatenção ao contexto. É preciso que haja, então, alguma intervenção para que seja despertada a atenção para o que há em volta, para a paisagem, para a realidade concreta. Só assim, com a apreensão do real, é possível a sua transformação. E para que haja apreensão do real é preciso que as pessoas sejam capazes não apenas de

\footnotetext{
${ }^{55}$ Idem nota 5.
}

56 Os Situacionistas eram um grupo europeu, das décadas de 50 e 60, do século $X X$, que se opunha ao urbanismo funcionalista de Le Corbusier e propunha a construção realmente coletiva das cidades, através da construção de situações em espaços públicos urbanos que não só permitissem, mas que instigassem a participação das pessoas. 
ler a cidade, mas de compreendê-la. $\bigcirc$ trabalho que propomos aqui, de certa forma, acompanha essas idéias. As pessoas precisam ser tiradas de situações habituais, cotidianas, para que atentem ao que está à sua volta; com essa atitude encontrarão coisas novas e estimulantes, seja para fruí-las, seja para transformá-las.

Em Paris, no século XIX surgiu a figura quase utópica do flâneur ${ }^{57}$;nele se materializa o que seria uma atitude oposta à do hábito, do cotidiano. $\bigcirc$ flâneur observava a cidade com atenção, passeando por ela com os sentidos alertas. "Na visão de Walter Benjamin da Paris do século XIX, o flâneur é um tipo importante, porque aponta para a posição central da locomoção na vida social: ele é constantemente invadido por ondas de experiências novas e desenvolve novas percepções enquanto cruza a paisagem urbana e as multidões." ${ }^{158}$ Essa possibilidade existe ainda hoje? A flânerie como método de leitura da cidade ainda é uma opção? Como ela se daria na metrópole de hoje onde a locomoção se dá de forma veloz, e muitas vezes dentro de algum veículo automotor?

No filme "Roma", de Federico Fellini, a apresentação da cidade se dá, no início e no fim do filme através de uma forma de flânerie: a entrada na cidade, vista através da janela de um automóvel, passando por um grande congestionamento nos dá a entender, a conhecer, uma parte significativa dessa cidade - confusão, sujeira, pobreza, desorganização, prostituição. Ao final, uma flânerie noturna nos dá a ver os monumentos iluminados, apresentando-nos uma outra dimensão da cidade. Passamos a conhecer um pouco dessa cidade que guarda e carrega uma carga histórica muito forte e é, ao mesmo tempo, uma metrópole, com todos os seus conflitos.

Michel de Certeau fala de "caminhantes que escrevem a cidade sem poder lê-la" ${ }^{\prime \prime}$. Seria essa uma das funções do arquiteto paisagista: a alfabetização

\footnotetext{
57 Do verbo 'flanar' - passear ociosamente; vaguear, perambular.

58 in "O Espaço da Diferença", de Antonio A. Arantes. Ed. Papirus, Campinas, SP. 2000.

${ }^{59}$ Idem
} 
paisagística? E o que é necessário para que as pessoas sejam capazes de ler e compreender a cidade de forma a serem capazes de participar de discussões a respeito de sua gestão? Ou referentes a projetos para seus espaços livres públicos? De que forma o arquiteto paisagista pode participar desse processo de aprendizagem de leitura? Que contribuições ele pode dar nesse processo?

"O papel do arquiteto paisagista... é o de encontrar a linguagem simbólica que, em cada cultura, consiga que as pessoas se sintam identificados com o espírito do lugar criado, transmitindo sentimentos ou evocações que lhes permitam sentirse bem a utilização desse lugar". (MAGALHÃES, 200 I: 40) E quem, senão elas próprias, são nossos melhores parceiros para identificar um espírito de lugar que as façam sentir-se bem ali?

\section{PAISAGEM}

alto grau de complexidade e de conflitos que as cidades brasileiras apresentam precisam ser conhecidos e enfrentados para que possam ser superados. Experiências de participação popular, sejam elas com adultos, crianças ou jovens, são um caminho muito rico e promissor nesse sentido, e com enorme potencial. Somos hoje milhares de pequenas comunidades em situações muito diversas e é preciso que seja feito um trabalho muito profundo de reconhecimento dessas micro realidades, para que as pessoas se apropriem da sua cidade, dos lugares onde vivem, para que tenham acesso à infra-estrutura necessária ao 'habitar'; e, caso isso ainda não seja possível, com condições de lutar por esse direito. Para isso é necessário ter a habilidade de ler e compreender a paisagem.

A paisagem é um conceito que permeará este trabalho; assim sendo, vimos a necessidade de discorrer sobre ele. Toda e qualquer paisagem é resultado da interação de dinâmicos processos sociais e naturais. Tais processos encontram-se materializados em formas e figuras lidas/percebidas de maneira diferenciada conforme inúmeros aspectos - etnias, culturas, formações profissionais, gêneros. A paisagem tem sido, ainda, objeto de investigação dos mais diversos campos de conhecimento, da geografia física e humana à antropologia, entre outras. A arquitetura paisagística, por sua vez, também tem construído seu corpo de 
conhecimento ao longo dos anos, ampliando o escopo e a abrangência desse campo disciplinar e projetual em função do reconhecimento de novas demandas e complexidades. Tem, portanto, no âmbito da apreensão, percepção, leitura da paisagem, uma inequívoca contribuição a oferecer.

Quando se pretende "ler" uma paisagem, é preciso conhecer sua sintaxe, sua morfologia, sua gramática, sua história, seus significados. A paisagem pode informar, pode expressar significados e informações acerca de sua história. Para esclarecer o que entendemos por paisagem, vamos percorrer rapidamente alguns autores, apenas para melhor vislumbrar o conceito.

Segundo Meinig ${ }^{60}$, existem 10 visões possíveis de paisagem: paisagem como natureza, hábitat, artefato, sistema, problema, riqueza, ideologia, história, lugar e estética.

Milton Santos diz: "Tudo aquilo que nós vemos, o que nossa visão alcança, é a paisagem. Esta pode ser definida como o domínio do visível, aquilo que a vista abarca. Não é formada apenas de volumes, mas também de cores, movimentos, odores, sons etc." ${ }^{\prime \prime 1}$

Segundo Simon Schama, "... a paisagem é obra da mente." ${ }^{162}$

"A paisagem constitui, em sentido lato, uma dimensão espacial com uma estrutura de organização definida pela interação de determinados ecossistemas que, em função da sua dimensão, intensidade e relação, estruturam o espaço e tipificam o território". 63 Segundo LIMA (2004), a paisagem é a "expressão física, morfológica, da interação da sociedade com os processos do suporte ecológico no tempo" e

\footnotetext{
60 MEINIG, Donald William - "The Interpretation of Ordinary Landscapes". New York: Oxford University Press. 1979.

${ }^{61}$ SANTOS, Milton - "Metamorfoses do Espaço Habitado". São Paulo: Hucitec. 1988. p. 61

${ }^{62}$ SCHAMA, Simon - "Paisagem e Memória" - São Paulo: Cia. das Letras. 1996.

63 “A Percepção Didática da Paisagem”, de Gonçalo J. Poeta Fernandes. - trabalho apresentado no $I^{\circ}$ Colóquio Psicologia Espaço e Ambiente, na Universidade de Évora. 2002.
} 
inclui "não apenas os espaços livres e construídos, mas igualmente a dinâmica das relações sociais; o inerte e o vivo, os objetos e as pessoas". (LIMA, 2004: I27)

Anne Spirn defende a idéia de que a paisagem é uma linguagem; e que ela pode e deve ser lida por quem com ela trabalha, por quem nela vive. Freqüentemente a paisagem é formada por várias camadas entretecidas e através da leitura dessa paisagem é possível entender, desvendar aspectos de sua história. Diz Spirn: "[o] contexto é um lugar onde processos acontecem, uma configuração de relações dinâmicas, não uma coleção de estatísticas estáticas." (1998) 64

Segundo Manuela R. Magalhães, paisagem pode ser entendiada como “...uma realidade ecológica, corporizada fisicamente num espaço que se poderia chamar natural ( se considerado antes de qualquer intervenção humana), no qual se inscreveram os elementos e as estruturas construídas pelo homens, com determinada cultura, designada também Paisagem Cultural." (MAGALHÃES, 200 I: 50)

Sem a pretensão de uma definição definitiva de 'paisagem', consideraremos a seguinte definição para o escopo deste trabalho: paisagem é a concretude de um lugar, conformada pela interação entre processos naturais e culturais que contribuem para sua contínua construção.

Para que se possa melhor compreender uma paisagem é preciso lê-la em variadas dimensões. "A leitura da paisagem é um método de trabalho que permite analisar uma paisagem interpretando a sua organização e até a sua história."65

"...[O] conhecimento que qualquer comunidade possui de uma paisagem que vivencia desde há muitas gerações, com uma experiência acumulada e progressivamente testada, representa o modo e a forma mais equilibrada de exploração de uma paisagem, em termos de sustentabilidade, considerando os

\footnotetext{
64 "The context is a place where processes happen, a configuration of dynamic relationships, not a collection of static statistics."

${ }^{65}$ Site do CEJA (Conselho Europeu dos Jovens Agricultores) http://www.ceja.educagri.fr/por/agriculture/a5/lecl.htm acessado em setembro de 2004
} 
recursos existentes em determinado período." (MAGALHÃES, 200 I: I | 3) Nas cidades brasileiras, principalmente em suas periferias, essa vivência de longo prazo da paisagem não acontece há muitas gerações. Não apenas as paisagens urbanas transformam-se muito rapidamente, como o fenômeno da migração interna faz com que as pessoas não tenham um conhecimento do lugar onde vivem, aonde chegaram há relativamente pouco tempo, não havendo tradição de ocupação e uso. A relação das pessoas com a paisagem de seus lugares de vida precisa ser trabalhada. Nesse sentido, "...a análise, a interpretação orientada da paisagem e o relacionamento integrado dos seus diversos elementos do espaço constitui um processo fundamental de educação, pela sensibilização à importância do ato de observar, como também pela valorização dos conteúdos eco-culturais presentes." ${ }^{166}$ O processo de 'interpretação orientada', como é aí chamado esse trabalho de percepção, leitura e compreensão de uma paisagem, é um dos papéis do arquiteto paisagista - como sensibilizador do ato de observar e analisar.

A percepção da paisagem, não raro, encontra-se embotada e fragmentada, sem que se revelem os processos subjacentes à própria paisagem, e cuja consciência seria de extrema importância para que se pudesse propiciar uma maior condição cidadã de participação em sua construção. Processos de leitura de paisagem que contam com a participação de arquitetos paisagistas em parceria com cidadãos comuns, leigos, têm o potencial de estimular sua percepção e seu interesse nela, que é a representação física de seu lugar de vida. Esse incitamento, esse estímulo tem o potencial de levar as pessoas a se envolver com questões importantes que influenciam direta ou indiretamente suas vidas, mas pelas quais, antes de serem suscitadas por essa leitura, não havia interesse e talvez pouco ou nenhum conhecimento.

Não se trata, de forma alguma, da abdicação do profissional à sua responsabilidade por um projeto; essa é a sua atribuição. Mas também é sua atribuição compartilhar seu conhecimento para interagir e dialogar com a população, e receber dela as informações necessárias para o desenvolvimento do

\footnotetext{
${ }^{66}$ Idem nota 63.
} 
projeto, estabelecendo um diálogo que permita construir algo em conjunto. Muitas vezes, critica-se a atuação de arquitetos paisagistas em processos participativos de leitura de paisagens no que ela às vezes divide e compartilha com leigos a elaboração de projetos, mas essa crítica não é pertinente, já que a proposta de trabalhos desse tipo é a elaboração de propostas a partir do diálogo, da troca de saberes, e não da delegação ou transferência de funções.

Segundo Guido de Almeida (1986, p. 69) a competência técnica ("domínio do conteúdo do saber escolar e dos métodos adequados para transmitir esse conteúdo") é fundamental para uma ação educativa. Diz ele: "Amor, amizade, carinho, ternura podem identificar o homem. O profissional caracteriza-se, identificase e define-se por sua competência técnica." (p. I I I) É portanto função primordial do profissional estar preparado para atuar, no sentido de transmitir o conteúdo específico de sua área às pessoas que estejam envolvidas num processo participativo, já que este tem em si o caráter educativo. A metodologia adequada deve ser elaborada, experimentada e analisada, o que procuramos fazer no Capítulo 3.

Mas, voltando à questão da leitura de uma paisagem como possibilidade de compreendê-la, devemos atentar para o fato de que, sendo a paisagem a concretude de um lugar, nossos sentidos são de grande valia nesse processo, sendo a visão o sentido primordial para nossa percepção. A forma concreta através da qual a paisagem se apresenta aos nossos olhos nos oferece muitas informações, mas é necessário que se tenha o cuidado de não tirar conclusões apenas a partir dos dados que a visão e os outros sentidos nos oferecem. Se ela é conformada, construída, pela interação entre processos naturais e culturais, é de fundamental importância 'ler' também tais processos para que se possa construir um entendimento mais completo e verdadeiro daquela paisagem. 
"...spare a moment to think what was on your land previously."

John Brooks

\section{A GEOGRAFIA E O LUGAR DA HISTÓRIA}

O campo da geografia nos oferece uma luz sobre essa questão. Deryck Holdsworth, geógrafo professor da Pennsylvania State University, diz que o "palimpsesto de formas de assentamento provê evidências efêmeras a serem lidas pelo turista da paisagem, mas é o trabalho sobre questões como o mercado de terras e de propriedade, e a resistência política a regulamentações como o zoneamento, que oferece uma arena mais sólida para a compreensão de paisagens-vestígio, no contexto de espaços sociais urbanos historicamente específicos." (GROTH, 1997: 47)

Esse autor destaca a impossibilidade de leitura de uma paisagem apenas a partir de suas evidências físicas, concretas, sendo primordial se compreender os processos sociais, econômicos e culturais que a conformam. Esta sua afirmação rebate a teoria de outros geógrafos, de uma linha anterior, denominada 'geografia cultural', que elabora suas teorias principalmente a partir de evidências visuais deixadas pela história como marcas concretas na paisagem. Os aspectos concretos, palpáveis, visíveis de uma paisagem são carregados de informações, mas é de fundamental importância não se ater unicamente a eles mas, de forma complementar, procurar conhecer os fatores sociais, econômicos e culturais que a configuraram, pois dessa forma o potencial, as possibilidades de propostas para a sua transformação poderão ser mais efetivas.

Num processo de leitura de uma paisagem, o conhecimento e a compreensão da sua história têm portanto uma contribuição inestimável a nos oferecer. Saber como e porque aquela paisagem se formou tem o potencial de nos fornecer informações importantes para se pensar uma atuação qualquer sobre ela.

67 ....dispenda um tempo para pensar o que havia na sua terra anteriormente." 
"Um dos aspectos a serem cuidados no ambiente urbano refere-se à sua adequação às necessidades da criança. Esse ajuste é básico para a formação das nossas futuras gerações. A responsabilidade por esse desenvolvimento está, em parte, alocada aos arquitetos e urbanistas." ${ }^{168}$

A adequação do ambiente urbano às necessidades não só da criança, mas também do adolescente e do adulto, passam obrigatoriamente por processos que incluam esses personagens, processos que envolvam a participação das pessoas que utilizam o espaço a ser trabalhado. Os arquitetos, arquitetos paisagistas e urbanistas não podem - e não devem - sozinhos, resolver essas questões numa prancheta, dentro de um escritório. E processos participativos devem conter a reflexão sobre a história do lugar.

Existem inúmeros caminhos a serem percorridos no sentido de atender ou cumprir a responsabilidade dos profissionais acima referidos nessa busca de adequação do ambiente urbano aos seus moradores. Esses caminhos vão desde a compreensão do que se vê e do que se vivencia no dia-a-dia, passando por discussões sobre as necessidades e desejos das pessoas que utilizam o espaço a ser trabalhado, até o entendimento de como o ambiente urbano se formou, sua história. Vamos procurar refletir sobre possíveis maneiras propor a jovens e crianças a compreensão da história da cidade onde vivem, dos seus lugares de vida. Isso é importante porque, para que esses adolescentes possam ser cidadãos e cidadãs atuantes e participantes, é preciso que saibam onde se situam, em que momento da história se encontram, o que é, como se formou, como é, afinal, o lugar onde vivem. É uma questão de cidadania. A história de um lugar nos oferece a perspectiva de inserção nesse lugar. 'Onde estávamos quando isto aconteceu?', 'Como viemos para aqui?', 'O que faremos de 'agora em diante?', são perguntas que facilitam a integração, ao menos emocional, de uma pessoa com o lugar onde vive. "O espaço da vivência" - a cidade - "contribui para a história da criança, o que requer que ele seja pensado, planejado e executado de forma a poder colaborar

68 OLIVEIRA, Claudia - "O Ambiente Urbano e a Formação da Criança". S. Paulo: Aleph. 2004. p. 16 
positivamente para a educação e para o desenvolvimento integral da criança." ${ }^{69}$ É preciso então que a história pessoal seja inserida, integrada à história da cidade. E parte de nossa responsabilidade diz respeito à troca entre conhecimentos técnicos e profissionais e conhecimentos experienciais e vivenciais que possibilitem uma articulação dessas histórias. E como pode se dar um trabalho que permita aos jovens ter uma melhor compreensão da história de sua cidade?

"Eu perguntei um dia ao neurologista Oliver Sacks o que, do seu ponto de vista, era um homem normal. Ele me respondeu que um homem normal, talvez, seja aquele que é capaz de contar sua própria história. Ele sabe de onde vem (tem uma origem, um passado, uma memória em ordem), sabe onde está (sua identidade) e acredita saber aonde vai (ele tem projetos e a morte, no final). Está, portanto, situado no movimento de um relato, ele é uma história e pode dizê-la a si mesmo." ${ }^{70}$ Compartilhamos desse pensamento, e por isso acreditamos ser fundamental, para pessoas em formação, passar por um processo de reconhecimento de sua história e da história de sua cidade. Drauzio Varella em seu livro para crianças, "Nas Ruas do Brás", apresenta a sua história e também parte da história da cidade de São Paulo, onde viveu sua infância. "Garoava muito em São Paulo; a cidade era cercada por matas e conhecida como a 'terra da garoa'.", Temos aqui algumas informações sobre a paisagem paulistana, que podem ser verificadas, comparadas, complementadas com dados recolhidos em outras fontes. Podemos perceber uma enormidade de informações sobre a cidade contida na história da pessoa Drauzio. Por exemplo, que as crianças da cidade passavam a maior parte do seu tempo nas ruas; esse era seu 'campo de provas', digamos assim.

Há algum tempo em São Paulo, "... todo menino era menino de rua."72 Hoje, segundo Claudia Oliveira, no ambiente urbano pode-se identificar três grupos

\footnotetext{
${ }^{69}$ Idem (p. 102)

${ }^{70}$ CARRÉRE, Jean Claude - in MACHADO, Regina - "Acordais". São Paulo: Difusão Cultural do Livro. 2004.

71 VARELLA, Drauzio - "Nas ruas do Brás". São Paulo: Companhia das Letrinhas. 2000.

72 Da música "A Mesma Praça", de Paulo Miklos, do CD "Paulo Miklos", solo. Warner Music. 1994. Letra completa no Anexo I.
} 
de crianças: "a criança que caminha pela rua", "a criança que não caminha pela rua" e "a criança em situação de risco social". A mesma paisagem é vista por elas a partir de diferentes pontos de vista. Uma vê a cidade do ponto de vista de alguém que utiliza os espaços públicos como caminhos que ligam os locais de moradia, estudo, trabalho, lazer; a segunda, a partir dos vidros dos carros, das janelas dos prédios, e que vê o espaço urbano de forma fragmentada, pois ela é transportada por outros de um lugar a outro, sem vivenciar os espaços que fazem a conexão entre eles; e a terceira é a que vive apenas no espaço público, que é seu lugar de moradia, trabalho, lazer e outros. "Caminhando, estamos no mundo, encontramo-nos num lugar específico e, ao caminhar nesse espaço, tornamo-lo um lugar, uma moradia ou um território, uma habitação com um nome."173 Isso é vivido de formas radicalmente distintas por cada um desses três diferentes grupos de crianças ou jovens, que têm uma vivência da rua, do caminhar pela cidade, completamente diferente uns dos outros. Podemos então afirmar, com quase toda certeza, que se crianças ou jovens desses três grupos - as que andam e as que não andam pela cidade; e cada uma com suas im/possibilidades - fossem escrever a história de uma mesma paisagem, escreveriam histórias muito distintas.

Muitas crianças e adolescentes hoje não convivem na rua pois ela se tornou um lugar perigoso; e isso é muito grave pois a rua é um dos palcos principais para o desenvolvimento, a construção da cidadania. A rua, como todo espaço público urbano, "atende a várias funções... como encontrar amigos, brincar, passear, praticar esportes, contemplar a natureza, etc." ${ }^{\prime 74}$ Mas nas grandes metrópoles ela se tornou isolada, praticamente desconhecida das pessoas que se locomovem dentro de veículos privados; e é vivida, por quem se locomove a pé ou de transporte público, de uma forma que não possibilita a aprendizagem, a prática e o exercício da cidadania.

\footnotetext{
${ }^{73}$ HILLMAN, James - "Cidade e Alma". São Paulo: Studio Nobel. 1993.

${ }^{74}$ Idem 68 (p. 17)
} 
"... we hold a sorrow deep within and cannot weep until that history is sung."75

Susan Griffin ${ }^{76}$

A construção da história num contexto pedagógico - algumas considerações

"Vi esta madrugada, no quintal, dois rapazes a imitarem rolas. ... Então, de repente, o que estava na árvore, meio oculto entre a folhagem ... levou à boca as mãos em concha e arrulhou. $\bigcirc$ outro riu-se, imitou-o, e era como se as aves estivessem ali mesmo... Se não tivesse visto os dois rapazes, se apenas os tivesse escutado, acreditaria que havia rolas na madrugada úmida." ${ }^{\prime 77}$ Este trecho do livro de Agualusa me chamou a atenção pelo fato de que muitas vezes a nossa percepção nos engana. Ouvir o som de rolas arrulhando poderia fazer com que se pensasse realmente que elas estavam ali, mas foi o sentido da visão que alertou o personagem para o fato de que eram rapazes imitando rolas. Para que possamos ler uma paisagem corretamente ou o mais aproximadamente possível da realidade, de forma que faça sentido, é preciso se fazer inúmeras aproximações, diversas leituras. Quanto maior a complexidade do olhar, maior o número de informações que se obtém para compor uma história.

Mas sabemos que "...histórias são escritas de perspectivas e pontos de vista fundamentalmente diferentes - na verdade irreconciliáveis -, sendo que nenhum deles é completo ou completamente 'verdadeiro.." 78 Como dissemos anteriormente, uma criança que vive na rua construirá uma história da cidade bastante diferente de outra que se locomove pela mesma cidade de automóvel. Então, para que a leitura de uma paisagem que permita a construção da história dessa paisagem seja abrangente, é preciso que, num processo de aprendizagem,

\footnotetext{
75 ،... guardamos uma tristeza no fundo de nossas almas e não podemos chorar até que esta história seja contada."

${ }^{76}$ S. Griffin é uma escritora norte americana ambientalista e feminista.

77 AGUALUSA, José Eduardo - "O Vendedor de Passados", Rio de Janeiro: Gryphus, 2004.

78 "...histories are written from fundamentally different - indeed irreconcilable - perspectives or standpoints, no one of which is complete or completely 'true'." - SCOTT, Joan W. "Experience", in BUTLER, Judith \& SCOTT, Joan W. "Feminists Theorize the Political", New York: Routledge (pp. 22-40), 1992.
} 
sejam feitas várias leituras. Num trabalho de grupo, além dessas diferentes leituras por uma mesma pessoa, há a possibilidade de haver leituras distintas por cada individuo, o que pode enriquecer sobremaneira a compreensão da paisagem e de sua história. Não apenas isso, mas esse procedimento permite também o entendimento de como se escreve história, fornecendo aos participantes do processo um arcabouço de experiências que não só possibilita, mas outrossim instiga à leitura crítica da história 'oficial'.

Ao mesmo tempo, sabemos que "[o] conhecimento não é um espelho das coisas ou do mundo externo. Todas as percepções são, ao mesmo tempo, traduções e reconstruções cerebrais com base em estímulos ou sinais captados e codificados pelos sentidos." (MORIN, 2003: 16) Aqui entram as comparações, os cotejos, as análises. $\bigcirc$ que percebemos nunca é simplesmente transcrito, mas sim traduzido com base nas nossas convicções, referências, ideologia, história pessoal, percepção, entre outros.

Uma outra questão importante a ser considerada num processo como esse é a incerteza. Sempre que estudamos história, devemos considerar a impossibilidade da certeza. A narrativa estará sempre nos apresentando uma versão de fatos. Morin atenta para a importância do enfrentamento das incertezas na educação: "[a] educação deveria incluir o ensino das incertezas que surgiram nas ciências físicas... nas ciências da evolução biológica e nas ciências históricas." (MORIN, 2003: 16) É muito importante que isto seja discutido, até porque no momento em que os jovens estiverem escrevendo a história da paisagem estudada, estarão escrevendo a sua versão, baseada em sua experiência e sua pesquisa. É importante e certamente enriquecedor notar as diferenças entre as narrativas de grupos de trabalho distintos.

Muitas áreas livres públicas e privadas tiveram intenção de projeto - praças, passeios públicos, parques, jardins franceses, praças medievais e outros. $\bigcirc$ que estamos discutindo aqui é o estudo da paisagem urbana que não tem, como um todo, intenção projetual; e não se tem aqui a pretensão de escrever história, mas sim de exercitar a compreensão da história de um lugar a partir da leitura de uma 
paisagem. Essa composição deverá se desenvolver a partir da vivência das pessoas, de sua história; só assim a história de sua cidade fará sentido para eles.

\section{O QUE ESPERAR DE PROCESSOS PARTICIPATIVOS?}

"A expectativa é de que os educandos que participam do processo de desenho comunitário também se apropriem de ferramentas, de um vocabulário técnico básico e de conhecimentos acadêmicos que, somados ao seu saber cotidiano, favoreçam a participação na gestão e modificação do espaço público de sua cidade."79

Este trabalho procura lançar algumas luzes sobre metodologias e conteúdos de trabalho que não apenas permitam, mas também impulsionem a participação efetiva das pessoas na construção de seus lugares de vida. Entendemos que essa construção se dá através de um encadeamento de ações e reflexões que se desenrolam ao longo do tempo. Qualquer passo nessa direção deve ser valorizado, considerado, registrado, e sobre ele deve se fazer avaliações críticas para que se possa avançar na compreensão de como se dá essa construção, e da forma como podemos contribuir para que ela seja formadora, educadora e resultante do diálogo entre todos os atores do processo.

Um projeto participativo para espaços públicos pode se limitar a diagnósticos, por exemplo, mas, como já foi dito anteriormente, é indispensável que isso seja absolutamente transparente e claro para todos os envolvidos.

Espera-se de um processo participativo que as pessoas e grupos envolvidos elaborem uma maior compreensão de seus lugares de vida, e desenvolvam capacidades, habilidades, vontade e intenção de participar de alguma forma em sua transformação para melhor.

\section{$\not$ 次加}

\footnotetext{
79 Idem nota 6.
} 
Consideramos então que numa proposta de processos de projeto participativo de espaços urbanos livres públicos é absolutamente fundamental o diálogo entre todos os participantes, e de forma igualitária. Através desse diálogo será possível criar algo novo, vivo, criativo, que possibilitará o verdadeiro envolvimento das pessoas no diagnóstico, planejamento, projeto e gestão desses espaços. Esse processo tem um grande potencial de abrir portas para a capacitação das pessoas para uma participação efetiva, onde suas idéias, propostas, sugestões, impressões, questionamentos, serão levados em consideração em todas as etapas do processo.

Como arquitetos paisagistas temos todas as condições para atuar na formação de cidadãos participantes contribuindo com os conhecimentos específicos de nossa área de atuação. Temos a convicção do enorme potencial de colaboração entre adultos e jovens, profissionais e leigos e de que dessa relação podem surgir propostas fortemente transformadoras.

"...[V]emos oportunidades fecundas para trocas de experiências e desenvolvimento de projetos conjuntos entre acadêmicos e profissionais das Américas que apostem na formação de uma rede capaz de fazer frente à complexidade dos fenômenos urbanos contemporâneos, e que estejam motivados para a busca de respostas exeqüíveis que contribuam para a construção coletiva de uma paisagem social e ambientalmente mais justa e equânime." (LIMA, 2004: 144) 
CAPÍTULO 2

Paisagem como Encantamento:

experiências 
"Leitura dinâmica

Essa tão badalada novidade da leitura dinâmica é muito, muito antiga... Quem a inventou foi o vento, o único que a sabe praticar de verdade. Inveterado leitor de tabuletas, ele não salta uma só que seja, não perde nenhuma delas. Lê e passa, que o seu destino é passar, mas guarda uma lembrança vertiginosa de todas, das vermelhas, das de azul mais forte, das verdes em todos os tons, sem esquecer,

ó Van Gogh, as tabuletas amarelas... Porque a maior dor do vento é não ser colorido. Sabes? Perpassa no vento a alma dos pintores mortos, procurando captar, levar (para onde?) as cores deste mundo. Que este mundo pode ser que não preste, mas é tão bom de olhar!"

Mario Quintana

Processos participativos de observação, discussão e desenho de espaços livres públicos têm, recentemente, sido objeto de interesse no Brasil e no mundo. Buscando compreender as possibilidades de trabalhos dessa natureza optamos por, inicialmente, apresentar algumas experiências de leitura de paisagem e/ou de projetos de espaços públicos dos quais participamos de alguma forma, para, a partir deles, procurar estabelecer algumas diretrizes de atuação. Elas foram desenvolvidas em escolas, praças e parques, por organizações não governamentais, associações e escolas e, em algum momento do processo, envolveram a comunidade local como sua interlocutora e/ou parceira. Essas experiências tiveram objetivos, escopos, e públicos alvo distintos, no entanto todas contribuem de alguma forma com a reflexão sobre projetos participativos que discutam o ambiente, a paisagem, os lugares de vida das pessoas, sejam elas adultos, jovens ou crianças. 
“...[E]m meio a um processo de decadência e colapso das cidades, resultado de seu abandono deliberado pelos beneficiários de novo arranjo global, e das novas tecnologias informatizadas, procura-se promover a idéia de sua refundação, não mais em bases históricas, democráticas e participativas, mas a partir de marcos de novos tempos, representados por grandes museus de arquitetura mirabolante e megacentros culturais. Em geral, esses projetos têm em vista um público que não é o local, empobrecido, mas visitantes prósperos de outras partes do país e do mundo." (SEVCENKO, 200 I, p. 128)

O presente trabalho busca, ao contrário disto, possibilidades de resgate ou reforço da conexão das pessoas com os espaços públicos de suas cidades. Essa busca é algo que vem ocorrendo em várias partes do mundo, de formas diferentes. Sevcenko cita, por exemplo, um grupo londrino - 'Regain the Streets" - que começou a atuar em 1995 e tem como projeto "a retomada e re-qualificação do espaço público, por gente simples e anônima, com o objetivo de revitalizar os laços comunitários e re-fundar a democracia com base na participação de todos, pelo bem comum." (SEVCENKO, 200 I: 129) No capítulo anterior citamos uns poucos grupos que desenvolvem atividades nessa direção e, a seguir, serão apresentadas algumas experiências que têm objetivos similares, das quais participamos em alguma instância.

Os relatos são apresentados numa linguagem informal pela riqueza de informações que carregam a respeito do clima em que transcorreram. Foram feitas apenas pequenas correções e adaptações devido ao caráter do presente trabalho.

\section{EXPERIÊNCIAS NO BRASIL}

De uma maneira que pode parecer contraditória, o primeiro relato descreve rapidamente o processo de elaboração do projeto de um parque público

\footnotetext{
I "Recuperar as Ruas"
} 
e sua implantação, pela Prefeitura do Município de São Paulo² em 2002, porém sem a participação dos moradores do entorno da área: o Parque Chácara das Flores, na Zona Leste da cidade; este não foi um projeto participativo. Ele será apresentado logo no início dos relatos apenas para servir de contraponto às outras experiências, estas sim participativas, descritas mais adiante.

\section{PARQUE CHÁCARA DAS FLORES}

A área do parque $\left( \pm 40.000 \mathrm{~m}^{2}\right)$, utilizada eventual e ilegalmente por alguns moradores do entorno, é rodeada por conjuntos habitacionais, tendo como um de seus limites o Córrego Lageado, totalmente poluído. Em 2002 ela estava cercada e era protegida de invasões pelo antigo proprietário que, como compensação legal de um empreendimento imobiliário feito na região, deveria passar sua propriedade à prefeitura. Havia à época, no Departamento de Parques e Áreas Verdes ${ }^{3}$ do município, um projeto antigo para a implantação de um parque naquele local. Em certo momento surgiram recursos para que aquele projeto fosse implantado, a área foi então recebida pela prefeitura, o projeto retomado, readaptado às condições correntes e finalmente implantado e aberto ao público. Essa área não havia sido reivindicada de forma organizada pela população, nem o projeto havia sido discutido com os moradores locais; no entanto, o parque passou a ser intensamente freqüentado a partir do instante de sua inauguração. Ou seja, ele atendeu à forte demanda que havia no local por uma área de lazer e esporte como aquela.

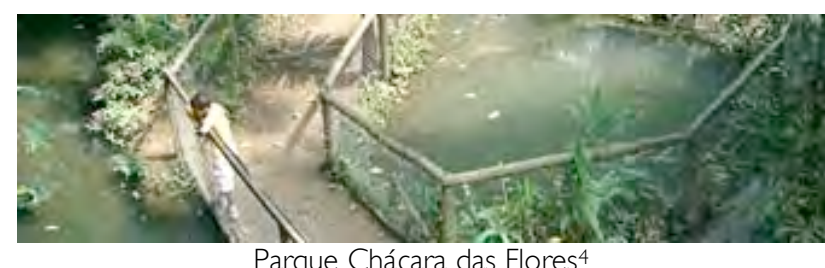

Parque Chácara das Flores ${ }^{4}$

\footnotetext{
${ }^{2} \mathrm{Na}$ época, eu trabalhava na Seção de Projetos do DEPAVE (Departamento de Parques e Áreas Verdes, da Secretaria Municipal do Meio Ambiente).

${ }^{3} \mathrm{Na}$ época, eu trabalhava na Seção de Projetos do DEPAVE.

${ }^{4}$ Do site da Prefeitura de SP: http://ww2.prefeitura.sp.gov.br/mapa_verde/img/pq_chac_flores.jpg
} 
O programa do parque contemplou quadras poli-esportivas, a recuperação de uma edificação e uma roda d'água antigas da fazenda que havia no local anteriormente, a conservação da parte significativa da vegetação, caminhos, área de lazer para crianças e um centro de educação ambiental. $\bigcirc$ córrego foi simplesmente isolado, não tendo sofrido nenhuma transformação.

\section{Algumas Considerações}

Não se pode dizer que ele não atendeu às necessidades dos moradores do entorno, no entanto eles não foram sequer consultados quanto a seus sonhos, desejos, necessidades e propostas quanto menos chamados a serem parceiros na elaboração do projeto. Não vamos discutir as razões que levaram a esse procedimento, mas pode-se dizer que o processo nem propiciou nem provocou transformações nas pessoas, pois elas não se apropriaram dele. Não se está entrando no mérito da qualidade do projeto do parque, e sim na forma com que ele foi elaborado e implantado.

\section{PARQUE PINHEIRINHO D'ÁGUA}

Esta foi experiência muito importante por seu caráter interdisciplinar, interinstitucional, e participativo. $\bigcirc$ projeto de um parque público foi desenvolvido numa parceria entre o poder público, a universidade e a comunidade, favorecendo sua capacitação para discutir e atuar sobre seu lugar de vida.

A área destinada ao parque $\left( \pm 300.000 \mathrm{~m}^{2}\right)$ fica na zona noroeste de São Paulo; é rodeada por conjuntos habitacionais, favelas e um condomínio empresarial; apesar de não ser cercada, foi protegida de invasões durante muito tempo pela população do entorno, que reivindicava a criação de um parque público no local. $\bigcirc$ projeto foi elaborado com intensa participação dos moradores do entorno. Houve discussões de propostas, muitas solicitações, e também um intenso envolvimento de alunos de escolas locais, catalisado pela ativa participação da professora de geografia do Ensino Fundamental, Márcia Penha de Rezende e centralizado na Escola Municipal Rogê Ferreira. 


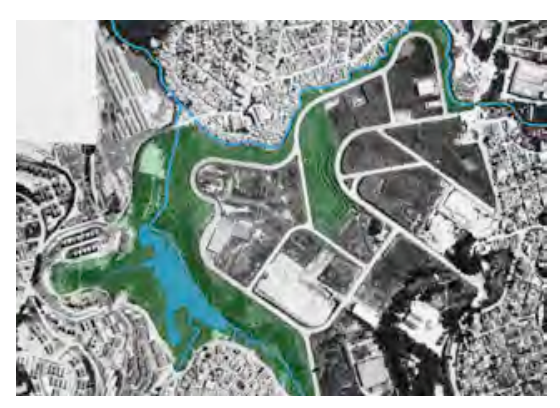

Foto aérea da área do parque ${ }^{5}$

Num primeiro momento foram realizados estudos do meio em outros parques da região; depois oficinas, caminhadas de reconhecimento, entrevistas, eleição do nome do parque, exposição de desenhos e redações, entre outras atividades; em seguida foram desenhadas propostas de projeto para o parque, propostas estas que foram apresentadas, discutidas, criticadas e, finalmente, sintetizadas em uma só. $\bigcirc$ processo ${ }^{6}$ envolveu, além de alunos de pós-graduação e profissionais da prefeitura, crianças, jovens e pais da Escola Rogê Ferreira e alguns moradores da região.

O projeto teve como parceiros a comunidade, o poder público e a Universidade, onde foi desenvolvida a disciplina de pós-graduação "Estúdio da Paisagem""7, para elaboração do projeto do parque através de um processo participativo. Esta disciplina incorporou profissionais dos parques e do Departamento de Áreas Verdes da Secretaria Municipal do Meio Ambiente biólogos, arquitetos, arquitetos paisagistas e agrônomos - para participar no curso junto com os alunos regulares.

Esse parque está sendo implantado pela prefeitura se não graças a, ao menos contando com intensa participação da comunidade escolar e de residentes do entorno e contribuindo com sua capacitação. Essa capacitação se fez presente em um momento em que a comunidade escolar questionou a Prefeitura quanto à

\footnotetext{
${ }^{5}$ Material utilizado durante o processo.

${ }^{6}$ Ele é comentado em LIMA, 2004.

${ }^{7}$ Professores responsáveis pela disciplina: Profa Dra Catharina P. C. dos Santos Lima e Prof. Dr. Paulo Renato Pellegrino
} 
possível paralisação do processo, apresentando argumentos consistentes contra essa possibilidade.

\section{Algumas Considerações}

Pode-se dizer que houve uma transformação importante na realidade local - as pessoas realmente se apropriaram do processo e têm hoje melhores condições de reivindicar o que desejam, com uma compreensão bastante ampla e complexa das questões ali envolvidas. Assim como no Parque Chácara das Flores, por ali também passa um córrego. Mas aqui o córrego foi entendido como recurso, bem como o brejo, as nascentes e um resquício de mata que ali se encontram. Hoje é possível discutir em detalhes algumas questões de projeto com essa população - tipos de cercamento, a necessidade de um centro de educação ambiental, a importância da preservação de nascentes - houve uma real apropriação do processo de entendimento do lugar e de criação de uma proposta de transformação para o seu uso e ocupação. Trata-se não apenas de uma ação de resistência, mas também do aproveitamento de uma 'brecha no consenso'; ; este conceito foi elaborado por dian marino ${ }^{9}$, educadora popular canadense, já falecida. Ele carrega a idéia de se buscar ocupar espaços de ação em brechas que o sistema dominante apresenta, possibilitando a transformação de atitudes, posturas e procedimentos. A proposta de um trabalho em parceria entre academia (a faculdade de arquitetura) e o poder público (a prefeitura) é uma maneira de compartilhar diferentes saberes e experiências a fim produzir um conhecimento diferente, novo e significante para os envolvidos. E a participação de profissionais de diferentes disciplinas favoreceu uma visão interdisciplinar do processo.

Este procedimento não é usual, não é padrão, mas como também não é proibido, havia uma abertura da qual o grupo pode se valer. Foi uma estratégia para estimular a discussão entre dois grupos: (I) os acadêmicos, com uma 'capacidade de sonhar' mais intensa porque trabalham normalmente no campo das idéias, e (2)

\footnotetext{
8 "brecha no consenso" é uma tradução livre de "crack in consent".

9 dian marino escrevia seu nome todo com minúsculas; optamos por respeitar essa grafia.
} 
os arquitetos, biólogos, arquitetos paisagistas, agrônomos e engenheiros da prefeitura que são acostumados a muitas limitações impostas por obstáculos práticos, pela prática diária numa instituição pública.

Estabeleceu-se um diálogo entre:

- o praticável e o impraticável,

- o possível e o impossível,

- sonhar livremente e considerar obstáculos.

Práticas como esta estimulam transformações na maneira como as pessoas estão acostumadas a pensar; nesta experiência o diálogo entre os grupos distintos de pessoas obrigou-as a debater e refletir de forma diferente da que estavam acostumados. "É amplamente aceita a idéia de que ensinar com e através do diálogo serve à democracia, promove uma comunicação através da diferença, e permite a co-construção ativa de novos conhecimentos e entendimentos."'0

Houve neste caso uma mudança na prática das duas instituições: a prefeitura, através de alguns de seus funcionários, aceitou participar de um curso na universidade, durante um semestre, com o objetivo de projetar um parque, atividade que estão acostumados a desenvolver em seus escritórios; e a universidade incluiu em uma turma de alunos de pós-graduação um grupo de alunos especiais, do Departamento de Parques, com a mesma finalidade; isso certamente realçou a qualidade do projeto, mas mais do que isso, propôs uma formatação nova para processos participativos de projeto de espaços livres públicos, onde a participação é o método de trabalho.

Tanto no Parque Chácara das Flores quanto no Parque Pinheirinho d'Água houve a participação efetiva de arquitetos paisagistas, mas apenas no segundo sua função extrapolou a ação de projetar em si e invadiu o campo da educação para a cidadania. A respeito disso, cabe a fala de Julia Pointer, jovem voluntária de Detroit,

${ }^{10}$ Nicholas C. Burbules 
sobre um trabalho desenvolvido no âmbito da iniciativa Growing Up in Cities, sobre a qual falaremos mais adiante:

"Ainda não fizemos desta cidade o que ela pode ou deve ser apenas pintando algumas casas e plantando alguns jardins... criamos a esperança que não havia antes." (in DRISKELL, 2002: 2I)

E não se trata de uma esperança vã, mas carregada de possibilidades reais. No caso do Parque Pinheirinho d'Água aconteceu um processo que se iniciou com a percepção da situação, do ambiente, caminhou para a reflexão, desembocou em uma proposta para uma nova coisa, e deve seguir o caminho da transformação, com a luta pela implantação do parque.

Relembrando a colocação de J. Burns, à página 15, neste processo a população não foi envolvida na fase de 'implementação', mas apenas nas de 'consciência', 'percepção' e 'tomada de decisões'. No entanto, a apropriação do processo pela população já se deu; o parque é dos moradores, apesar de ainda não implantado completamente. $\bigcirc$ processo ainda está em andamento, tendo havido inúmeras intercorrências de natureza política, e as pessoas continuam discutindo o parque. E se processos sociais são um dos objetos da arquitetura paisagística, então aqui ela cumpriu sua função.

\section{ESCOLA ESTADUAL ALBERTO TORRES}

Em 2004, o diretor da Escola Estadual Alberto Torres, situada na zona oeste de São Paulo, procurou a FAU USP para a elaboração de um projeto para a área livre da escola, de aproximadamente $2.000 \mathrm{~m}^{2}$, e a solicitação foi encaminhada para o LabPARC'I. A escola é vizinha de uma Escola Municipal, um Centro de Saúde Municipal e tem o Córrego Pirajussara como limite de terreno. O córrego é bastante poluído e a área junto ao córrego não recebe manutenção de nenhum tipo, o que causa sérios problemas de higiene e conforto. Existem algumas áreas

\footnotetext{
1 'LabPARC - "Laboratório Paisagem, Arte e Cultura", grupo de pesquisa em projetos participativos para espaços livres públicos, da FAU USP, cujos coordenadores são os Profs. Drs. Vladimir Bartalini, Vera Pallamin e Catharina Pinheiro Cordeiro dos Santos Lima.
} 
mais ou menos definidas em função do uso, mas a maior parte desse espaço livre não é utilizado nunca, sendo que alguns desses locais são interditados ao uso por questões de segurança. Há um campo de futebol que é regularmente alugado para terceiros; existem algumas espécies arbóreas frutíferas; com exceção do campo, o espaço é praticamente abandonado, encontrando-se mal cuidado, com mato alto, algum entulho, enfim, sem condição de uso.

Foi proposto um trabalho com a participação de alunos, professores, coordenadores e funcionários para discutir um projeto para esse espaço. A diretoria da escola disponibilizou alguns minutos de uma reunião de professores para que nos apresentássemos e à nossa proposição. A primeira atividade seriam oficinas para estabelecer um diálogo com a comunidade escolar para pensar um possível trabalho em parceria. No dia combinado apareceram 3 ou 4 pessoas. Não seria possível fazer as oficinas, mas em respeito às pessoas que haviam comparecido, decidimos fazer uma visita conjunta aos espaços livres da escola. Algumas questões foram destacadas pelos poucos professores presentes, uma funcionária e alguns poucos alunos que foram convidados na hora:

- nem todos conhecem o espaço; nem mesmo a coordenadora (os que conhecem, não sabem o que tem na área do campo de futebol (o campão); uma bedel era a única que conhecia todos os espaços livres (nos guiou e abriu todos os portões);

- os adultos têm medo de 'soltar' as crianças;

- é necessário melhorar a infra-estrutura e o conforto da escola (banheiros e vestiários destruídos, fechados, fedidos);

- faltam lixos e bebedouros;

- $\quad$ mais de 100 pessoas freqüentam a escola (área do campão) nos finais de semana (não necessariamente seus alunos);

- a cobertura da quadra interna tem vazamentos;

- $\quad$ é preciso colocar redes de proteção para as bolas não 'voarem longe';

- $\quad$ no espaço da zeladoria é preciso manter a privacidade da familia que mora no local;

- a raiz de uma seringueira estraga todo o encanamento e há muitos vazamentos;

- como administrar para não haver deterioração? 
- as pessoas gostariam que o espaço livre tivesse:

- locais para leitura

- ambientes que educam (sem precisar de alguém para ensinar - tipo um jardim com rosa dos ventos)

- local para dar aula ao ar livre

- espaço para confraternização (churrasqueira);

E também surgiram muitas déias:

- identificar plantas que vão ser plantadas e que já existem (nome, típica de onde, se é medicinal, etc.);

- resgatar a história do local (Escola Rural) e fazer pequenas plantações, pomares para valorizar essa história;

- aproveitar salas sem uso para jogos, computadores (que tinham antes, patrocinados pelo Senac);

- fazer uma cerca viva ('muro vegetal') ao redor da escola;

- colocar mesinhas;

- plantar uma roseira;

- colocar um piso nos 'jardins internos' (perto da lanchonete!);

- fazer parquinho;

- fazer anfiteatro;

- fazer um mezanino na biblioteca e abrir para o espaço livre (não há espaço de estar);

- reformular o jardim interno da sala dos professores que só é usado atualmente por fumantes (estava cheio de bitucas de cigarro pelo chão e vegetação plantada aleatoriamente);

- colocar mesinhas com tabuleiro de xadrez;

- fazer um berçário para filhos/as de professores/as;

- ter espaço para teatro na 'casinha';

- fazer um jardim;

- $\quad$ estruturar uma sala de leitura ao ar livre ("biblioteca precisa aumentar - alunos em grupo, professores pesquisando têm que conviver");

- organizar a área para quem assiste aos jogos na quadra;

- fazer uma sala de jogos;

- construir um half para skate. 
Algumas frases mostram como o estímulo pode despertar a percepção e a imaginação das pessoas:

- $\quad$ "Precisamos preservar e utilizar a natureza."

- "Gente, olha como é bonito!" (falando da vegetação)

- $\quad$ "Precisamos de outra entrada social. Esta é fria, sem presença."

- "Imagina aqui uma horta comunitária! Até vejo!"

- "Tem muita área para se esconder."

- "Queremos espaços agradáveis para as pessoas virem para a escola com prazer." (prof. geografia)

- "Bota essas crianças pra correr, gastar a energia!" (coordenadora conhecendo a área do campo de futebol)

- "Nós vamos colocar grade aqui, não custa quase nada!" (diretor)

- "A molecada quebra tudo!" (mostrando o estado dos banheiros)

- "Por que as pessoas têm que ficar confinadas?!"

A escola não é um local que as pessoas apreciam, mas ao mesmo tempo, havendo oportunidade de participação as idéias fluem e a vontade de transformar a escola para melhor aparece claramente. Foi solicitada uma nova oportunidade ao diretor e alguns professores e um novo convite foi feito diretamente aos alunos para as próximas oficinas, durante o período de aula, passando de classe em classe para apresentar o LabPARC e o trabalho proposto, deixando claro que:

- $\quad$ o produto do trabalho conjunto seria um projeto para as áreas livres da escola;

- não havia nem verba, nem direito legal para implementar o projeto;

- $\quad$ a Universidade gostaria de trabalhar em parceria com eles nesse projeto, por acreditar na possibilidade não só de se chegar a um resultado satisfatório, mas também ser possível o desenvolvimento de um trabalho em parceria com eles para buscar uma proposta de transformação para os espaços livres de sua escola;

- o projeto poderia futuramente servir de apoio para a escola buscar patrocínio para a sua implementação. 
Foi passada uma lista para que os alunos que estivessem interessados em participar se inscrevessem. Setenta e seis alunos, da $5 \mathrm{a}$ à $8 a$ série, colocaram seus nomes nas listas. Sorteamos dois alunos de cada classe - um menino e uma menina - para participarem da oficina seguinte que ocorreria no período de aula.

Dezesseis crianças e jovens compareceram, e a oficina foi realizada numa marquise de entrada dos alunos e área livre contígua. Não houve nenhum apoio do pessoal da escola para garantir o seu comparecimento. Inclusive a carta que seria enviada aos pais informando-os sobre a atividade, não o foi.

A atividade se iniciou com uma roda de apresentação (nome, série, idade, o que gostava de fazer nas horas livres e a matéria de que mais gostava):

Rafael - jogar bola no programa 'Escola da Família',2, nos fins de semana/ educação física

Hugo - jogar bola, videogame/ não gosta de estudar (foi embora logo depois desta dinâmica)

Ricardo - jogar bola, videogame, andar de bicicleta

Maristela - ver TV, jogar bola, videogame

Camila - andar de bicicleta, jogar futebol

Tamires - jogar vôlei, cantar no coral

Rodrigo - jogar xadrez, andar de bicicleta/ matemática

Rúbia - ouvir música

Juliana - esportes/educação física

Caroline - ver TV/não gosta de nenhuma matéria

Marcelo - educação física

Paola - jogar futebol, jogar vôlei, ver TV, brincar com os primos/ português

Em seguida, depois de dar uma caminhada pelo espaço para despertar, através do contato visual, sua atenção com relação a ele, foi solicitado que dissessem o que achavam do lugar:

\footnotetext{
12 'Escola da Família' - programa de atividades culturais e esportivas que se desenvolviam nas escolas estaduais durante os fins de semana.
} 
- $\quad$ alguém diz que seria legal se houvesse uma placa na porta da escola: "Bem vindos à Alberto Torres!" (idéia não aprovada pelos colegas que brincaram dizendo que seria preciso escrever "Bem vindos ao inferno!');

- mais pintura e mais arte;

- limpeza do espaço, que tem muito lixo e coisas quebradas;

- balança, pula-pula, parquinho, piscina, jardim, cinema, escorregador/tobogã, coqueiros para beber água de coco;

- bancos ao invés dos tocos de árvore (existentes) simulando bancos;

- " "se cuidassem ia ser 'da hora'!"

- $\quad$ sugestões de nomes para aquele espaço onde estávamos: Praça da Amizade, Praça da Liberdade, Praça do Namoro, Praça da Sujeira, Praça do Matagal, Praça dos 3 Ms, Praça do Rap, Área Livre, Cantinho da Expressão.

Em seguida, numa sala de aula, foi solicitado que representassem, individualmente, o espaço onde tínhamos estado trabalhando. $\bigcirc$ material usado, e que ficou no centro da roda, foi: papel sulfite, canetas hidrográficas, lápis de cor e de cera, lápis preto, tesoura, cola, revistas, bloquinhos de madeira, palitos de sorvete coloridos e fita crepe. Deixou-se claro que não seria feita nenhuma avaliação estética (bonito/feio), que não era preciso se identificar assinando o trabalho, que não seriam feitas comparações entre os trabalhos, que aquela proposta pretendia facilitar a compreensão do espaço e de seu potencial. Essa fala quebrou a resistência de alguns.

Ao final da atividade, foi pedido que cada um descrevesse, através da escrita, o que havia representado com desenho, colagem ou 'maquete'. Abaixo, alguns dos desenhos e os textos correspondentes:

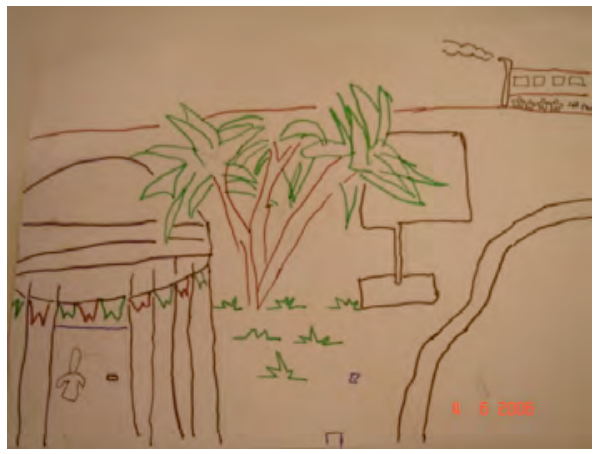

"O desenho representa escola ruim, quero uma escola melhor. É só." 


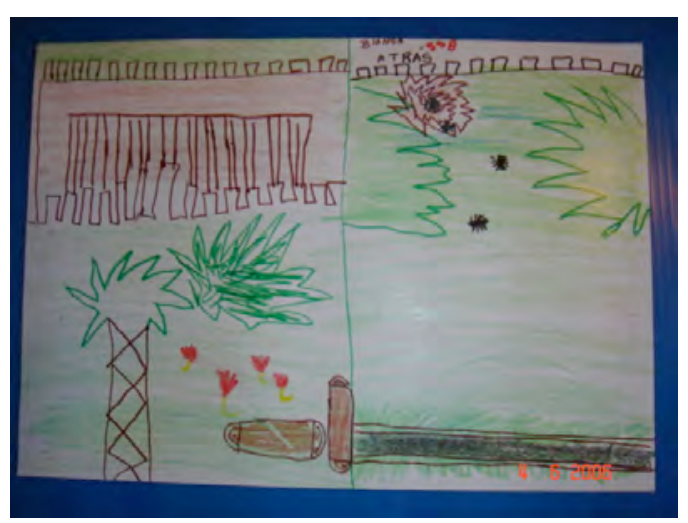

"O desenho que eu fiz representa o lixo que tem na escola. Atrás eu fiz o que tem, aranhas, mato, lixo, acho que tem dengue e outros. Na frente tem mato, grama, árvore, flores no chão, e bancos de madeira e uma sala que o grêmio esta colocando bandeirinha."

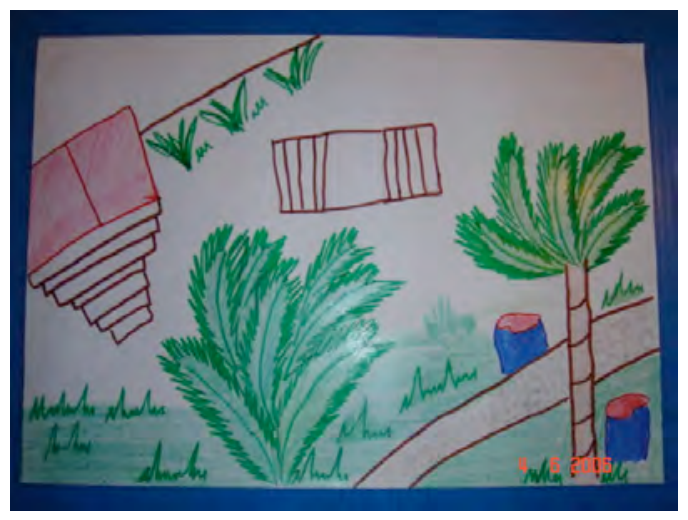

"Bom! Eu desenhei os pés de coqueiro, o pátio da escola, os banquinhos de madeira, as salas vazias, e o monte de mato."

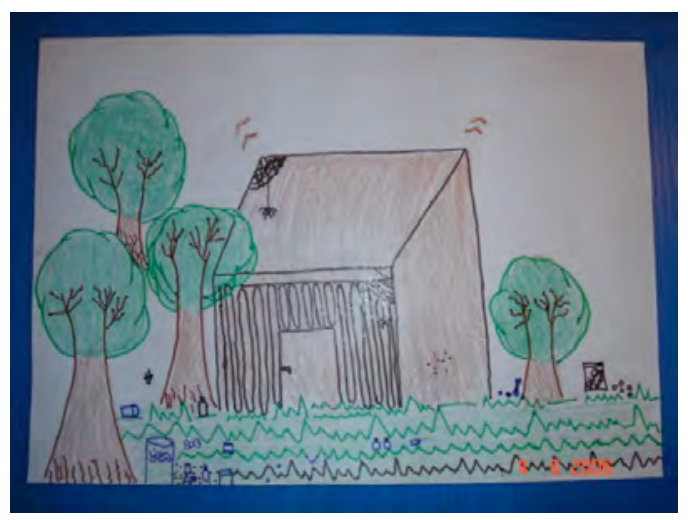

"Eu desenhei simplesmente o que eu acho que tem: vários papéis de bala, tem salgadinho no chão, tem árvores, muito mato, e uma pequena sala, várias teias de aranha e muito inseto, vários bichos e também eu quis deixar claro que a grama está altíssima." 


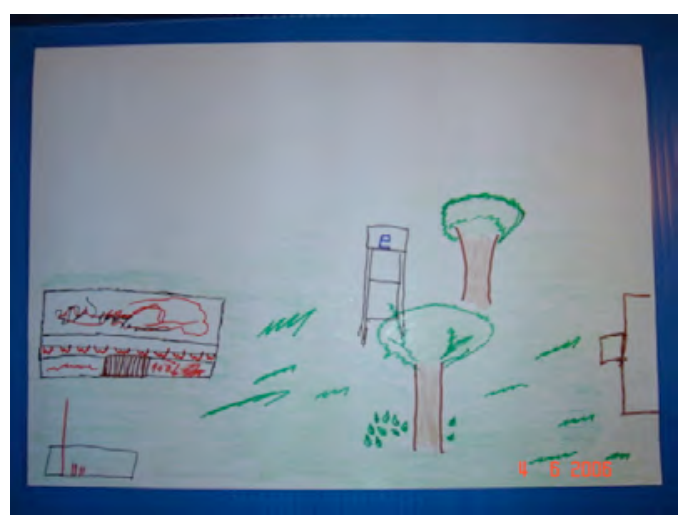

"Eu fiz aquela escolinha ou casa sei lá o que é, fiz as árvores, aqueles ferros e é claro fiz o chão."

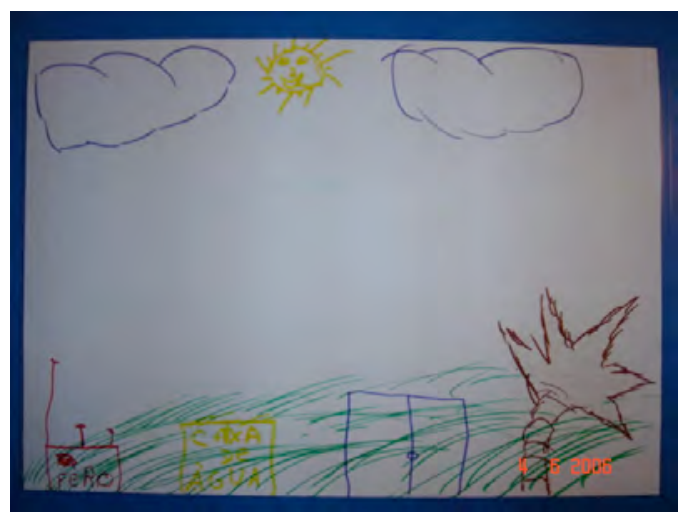

"Eu acho que o que eu desenho tem que mudar muito mais do que isso, eu espero que pinte a escola por dentro e por fora, tem que mudar o estilo."

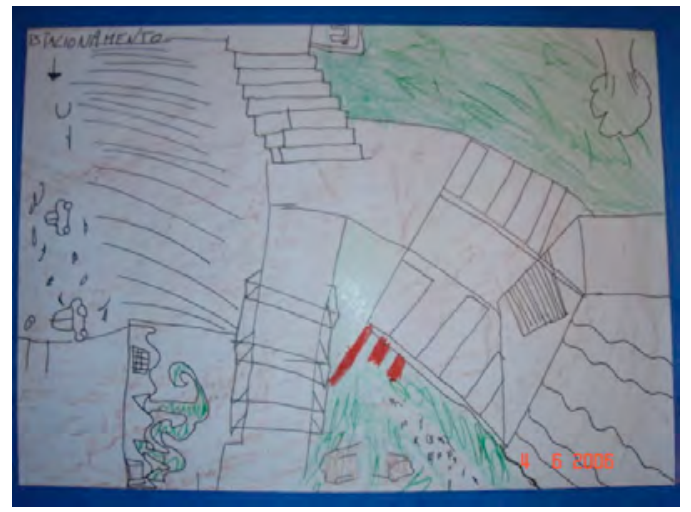

"Eu desenhei a entrada da escola. Desenhei os troncos que tem lá na entrada os ferros quebrados e tudo que tem lá na entrada." 
Alguns fizeram representações tridimensionais:
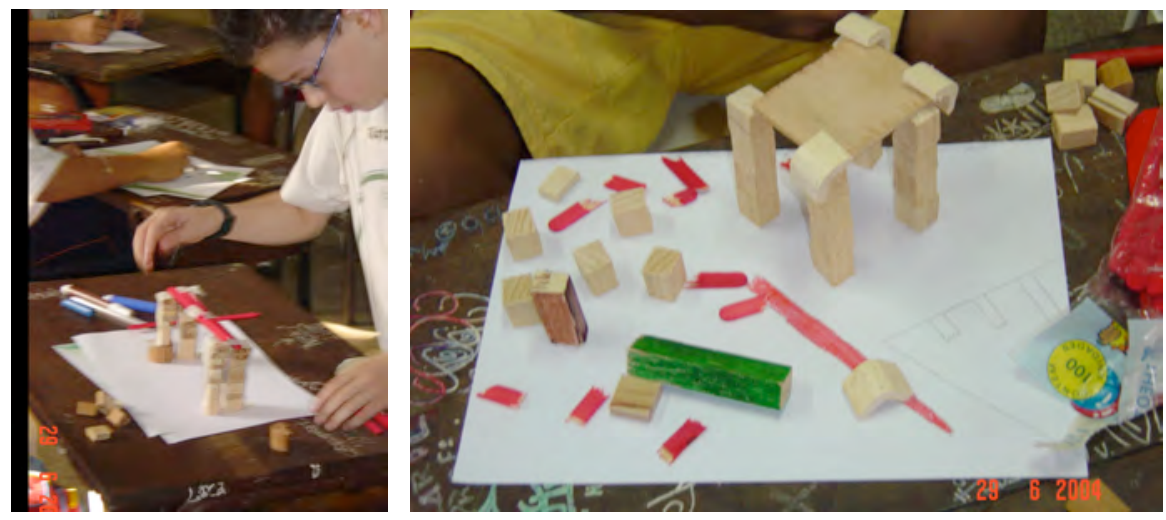

"A escultura que eu fiz significa aquela sala lá fora."

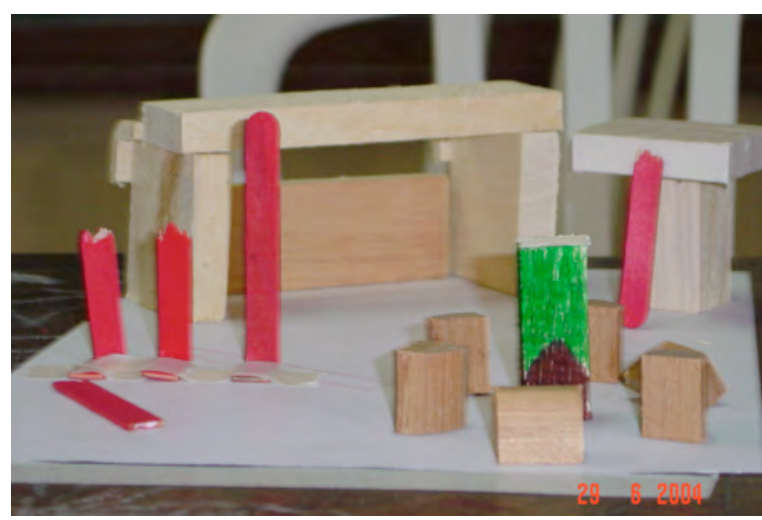

"Eu, ..., fiz a caixa d'água, o lugar das salas, os troncos e as árvores e aqueles ferros vermelhos."

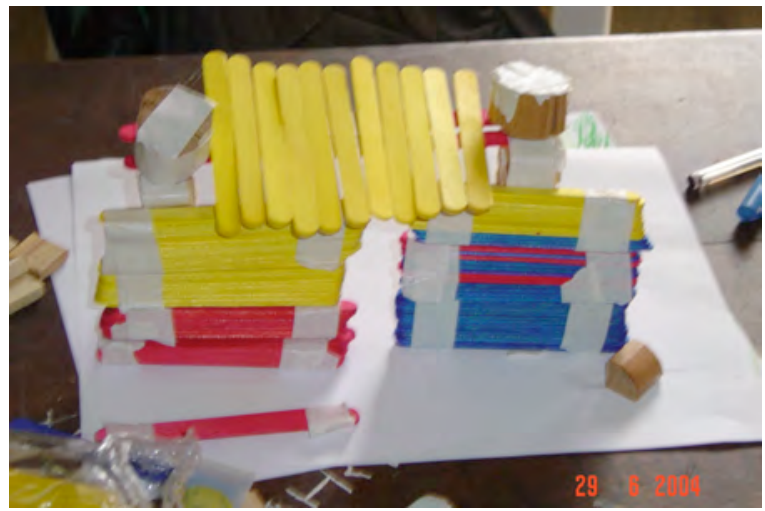

"Eu fiz uma maquete, eu fiz as salas de fora, a caixa d'água, os ferros quadrados, as árvores, os bancos de troncos de árvores. É lixo."'3

\footnotetext{
${ }^{13}$ Foram feitas correções mínimas nos textos dos alunos, apenas para sua compreensão.
} 
De volta ao espaço da conversa inicial, os alunos fizeram a representação, em 3 dimensões, dos elementos que gostariam que existissem naquele espaço. $\bigcirc$ material utilizado foi: tecido, corda, caixas de papelão, tesoura, estilete e fita crepe. Eles se organizaram naturalmente em grupos e construíram bancos, balanças, gangorras, árvores frutíferas e um escorregador.
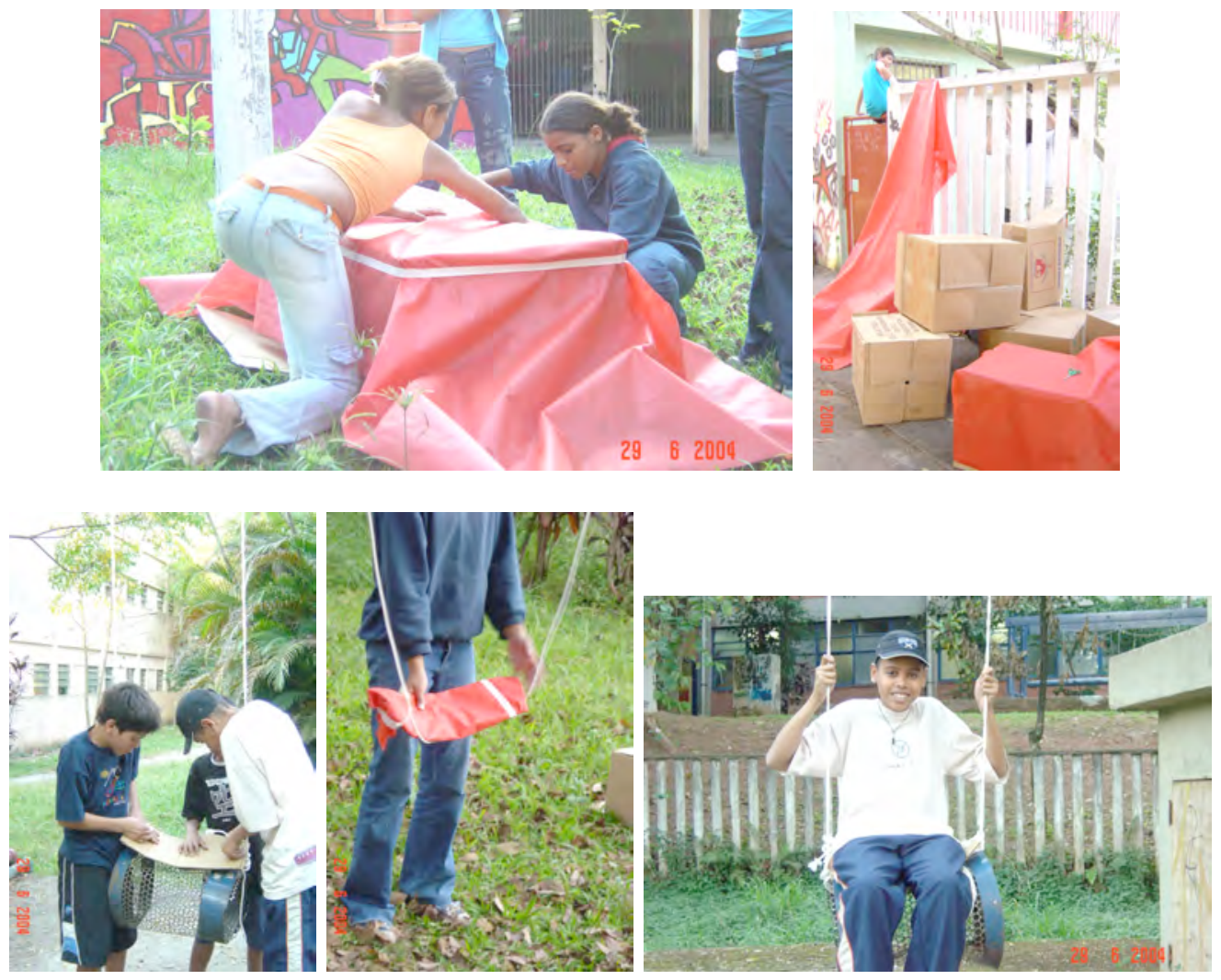

A balança

Ao terminarmos a oficina, a porta da sala onde estaria o lanche providenciado pela escola havia sido arrombada e o lanche havia desaparecido. Eles ficaram muito indignados e tristes eles acabaram se dispersando; despedimo-nos deles com acenos de mão.

\section{Algumas Considerações}

Não apenas, mas também por motivos alheios a ele, este trabalho não teve prosseguimento. $\bigcirc$ não comparecimento de alunos à primeira oficina, o fato de a prometida carta-convite da diretoria aos pais não ter sido enviada quando da segunda tentativa de se fazer a oficina, e a falta da designação de alguém do corpo 
docente da escola como responsável pelo projeto foram alguns sinais negativos. Ainda assim algumas considerações são pertinentes.

As crianças e jovens que participaram da oficina têm uma percepção muito aguçada de seu ambiente; estimulados, elaboram muitas idéias, propostas e uma infinidade de sonhos; não têm orgulho nem prazer com sua escola, mas adorariam tê-los. Não estão acostumados a serem ouvidos, então o trabalho no sentido de fazerem-nos se expressar, é bastante árduo. $\bigcirc$ mesmo podemos dizer com relação aos professores; eles têm um forte desejo de incorporar os espaços livres como espaço de ensino/aprendizagem, entendendo-o como um local rico em potencialidades para tal e as salas de aula thes parecem restritas.

As atividades de expressão (desenho e construções em três dimensões) funcionam como excelentes catalisadores de uma conversa acerca do espaço da escola; no momento em que os jovens e crianças 'põe a mão na massa', abre-se uma porta de entrada diferente para a abordagem da questão do espaço. As artes plásticas são uma linguagem muito apropriada para estimular sua percepção do ambiente em que vivem. Para eles, falar de algo que se observa, com o qual se tem contato direto, é mais fácil, mais rico, mais interessante do que discutir um assunto de forma abstrata. "Trabalhar com a paisagem geográfica a partir da arte é uma forma de desvendar a dinâmica de formação e transformação dessa paisagem e também construir um novo olhar e percepção sobre a paisagem, a fim de que o individuo se torne sensível à mesma." (MYANAKI, 2003)

Os mais jovens tiveram mais facilidade na atividade na sala de aula; os mais velhos têm a auto-crítica e a auto-censura mais desenvolvida, o que dificulta sua expressão, principalmente porque não havia nenhuma intimidade entre nós; estávamos nos conhecendo naquele dia. A liberdade de expressão pode ser conquistada em um processo de mais longo prazo, onde se estabeleçam a confiança, a auto-confiança e o entendimento dos objetivos das atividades.

Para que o trabalho tivesse um bom andamento seria necessário o estabelecimento de uma parceria entre a universidade e o corpo docente da escola, com um compromisso explícito da comunidade escolar. 


\section{COLÉGIO ÍTACA}

O Colégio Ítaca é uma escola privada de Ensino Fundamental e Médio, localizada na zona oeste de São Paulo, na Avenida Pirajussara, por onde corre, no subterrâneo, o córrego de mesmo nome. Em 2004 foi oferecida a disciplina optativa "A Cidade Escondida", tendo como objetivo desenvolver a percepção com relação à cidade e, mais especificamente, ao bairro em que se vive, de forma a contribuir na formação de cidadãos mais conscientes e participativos no que diz respeito aos espaços públicos. ${ }^{14}$

Segundo Raul Pereira, o local mais adequado "para um campo de conexão, capazes de estabelecer uma pratica de reflexão mais permanente, entre o espaço da cidade e o conjunto de moradores..." é a escola, "onde se reúnem diária e sistematicamente os elos mais frágeis, vulneráveis e potencialmente criativos do universo urbano: os jovens e as crianças"; e ela é "um dos poucos espaços da cidade que possui essa efervescência concentrada de possibilidades e esperanças, mesmo que potencialmente represadas." (2006: 124)

A proposta foi apresentada aos alunos e uma classe se formou com jovens do $1^{\circ}$ e $2^{\circ}$ ano, onze de cada um, com meninos e meninas em número praticamente igual.

Não serão aqui descritas todas as atividades desenvolvidas; apenas as mais significativas. A primeira delas foi a observação e desenho dos espaços externos da escola, com destaque para o local preferido e o local preterido, acompanhado de justificativa dessa escolha, apontando aspectos positivos e negativos de cada um. A discussão resultante dessa pesquisa feita pelos alunos permitiu ver o quanto variam as preferências de cada um e como a percepção pode ser estimulada.

\footnotetext{
${ }^{14}$ Anexo VII - Programa dessa disciplina.
} 

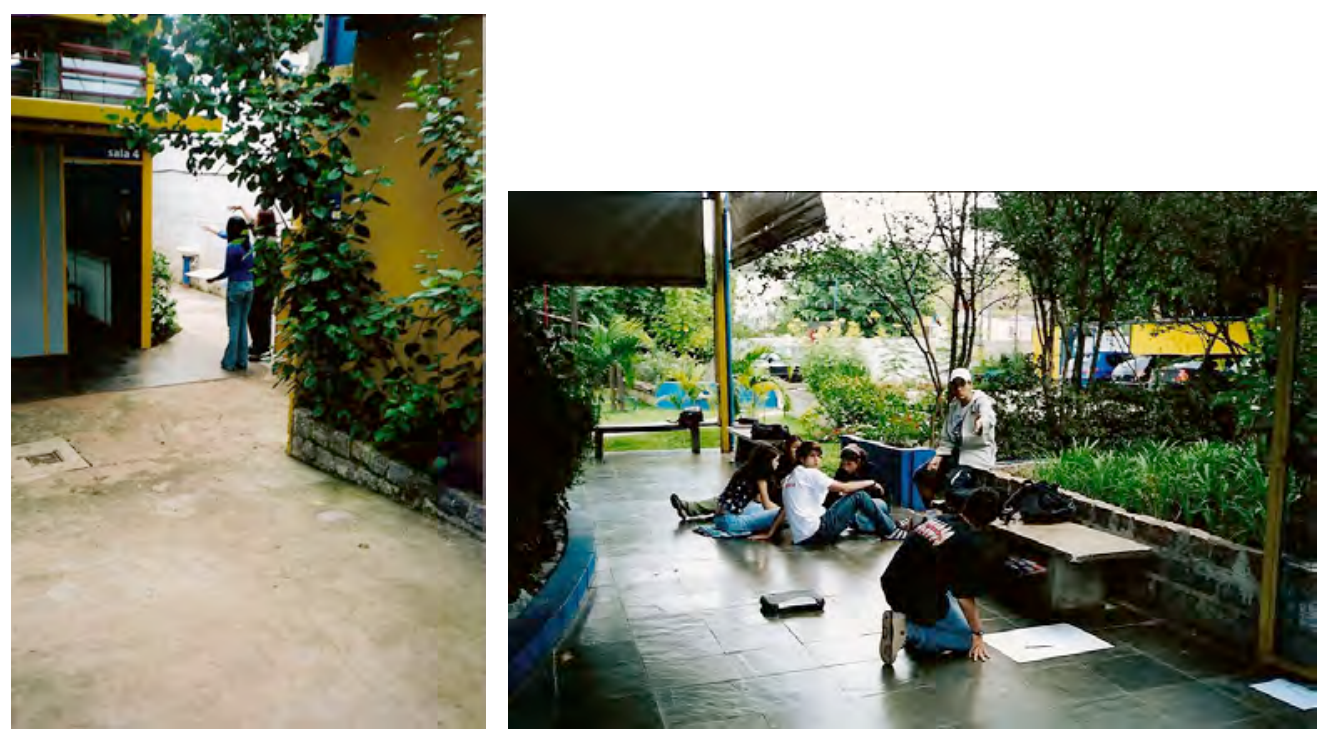

Alunos do Ensino Médio desenhando seus lugares preferidos e preteridos

Aconteceu também a discussão sobre um artigo de jornal (Anexo II), uma entrevista com Enrique Peñalosa, prefeito de Bogotá, Colômbia (Anexo III) e a audição e discussão de músicas que falam da cidade de São Paulo (Anexos I e IV).

Outra atividade ainda foi o desenho do percurso casa-escola, com pontos de referência; abaixo, alguns deles:
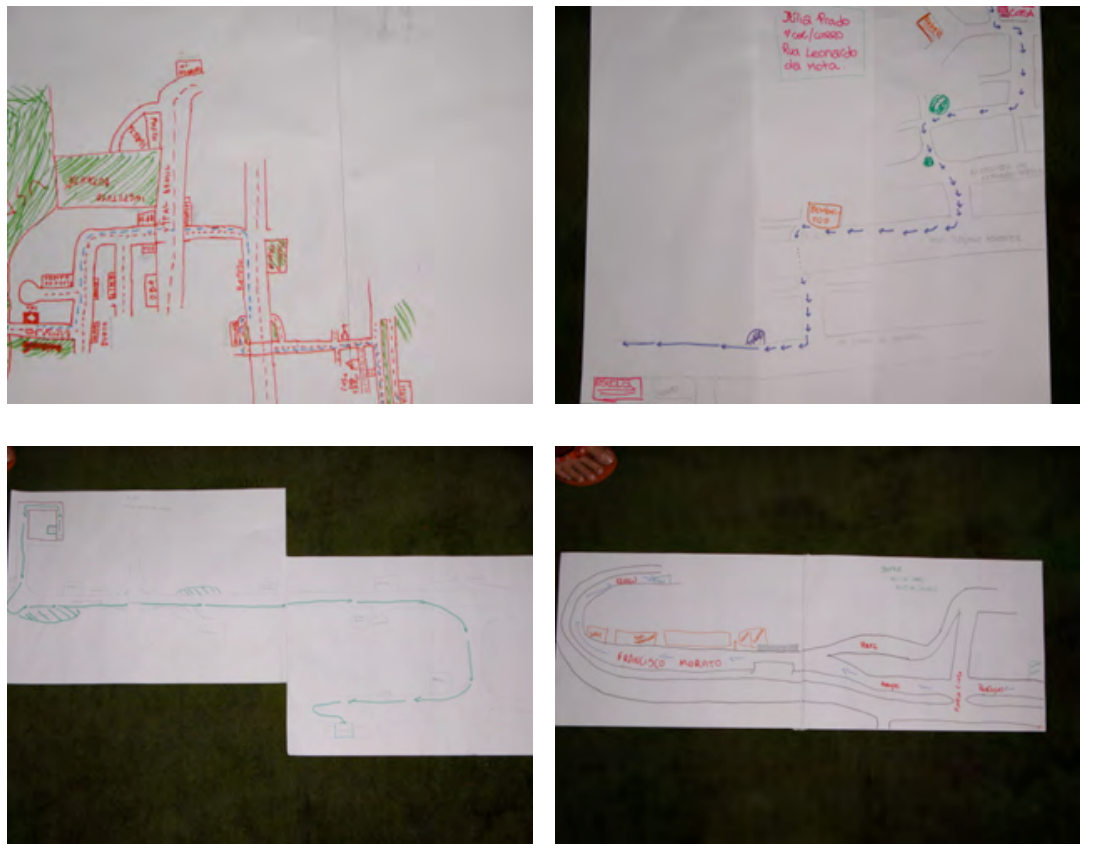

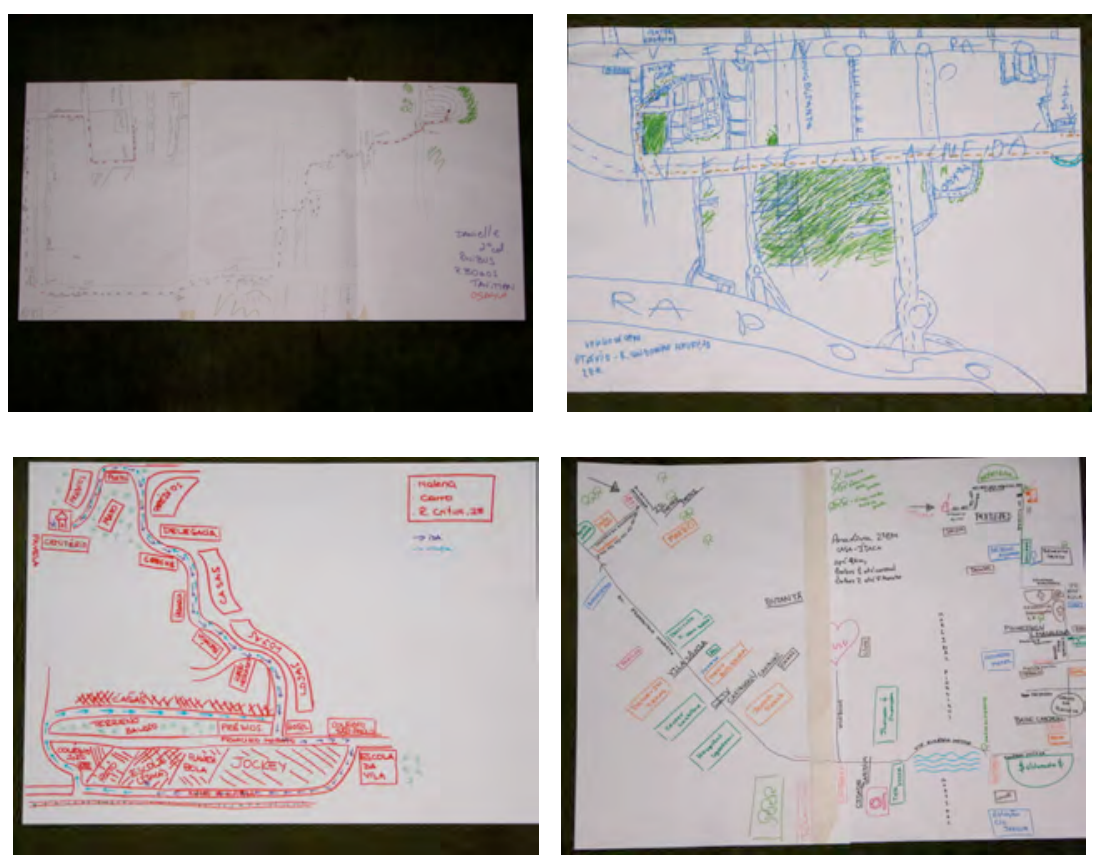

Com esse exercício pretendia-se discutir se há e quais são as diferenças de percepção da cidade, entre pessoas que andam a pé, de ônibus ou de carro. Isso não foi possível por problemas de dinâmica do grupo, que apresentou muitos problemas ao longo do curso, devido à aparente, para nós, desorganização do grupo. Isto será comentado mais adiante. Seguem abaixo algumas descrições de seus percursos casa-escola.

"No percurso da minha casa até a escola passo por duas avenidas bastante movimentadas, a Três Poderes e a Pirajussara. $\bigcirc$ caminho para ir até a escola é muito pequeno, saio da rua que eu moro (Valdomiro Fleury) e já entro na Três Poderes, e logo em seguida na Pirajussara, onde ando cerca de $2 \mathrm{~km}$ até chegar à escola; na trajetória vejo casas, prédios, um shopping e asfalto, o verde é pouco presente nesta área.

"No caminho da minha casa até aqui há uma grande avenida movimentada, diversas áreas verdes, por exemplo, o Parque da Previdência e muitas praças."

"Passo ao lado de um bosque, passo pela portaria do condomínio, pego a Raposo, passo pelo [Condomínio] L'Habitare, passo por baixo da passarela do [Supermercado] Sé, saio da [Rodovia] Raposo [Tavares], passo por uma padaria, passo por 4 semáforos, faço o retorno e chego na escola." 
"Passo primeiro por uma avenida que é muito movimentada e nela o que mais me chama a atenção é o grande número de policiais. Também me chama atenção o grande número de árvores do bairro. Em seguida, entro na Francisco Morato, que é uma avenida que eu considero muito feia, pois nela existe muita poluição visual. A rua Caminho do Engenho, a última pela qual passo, é agradável, apesar de haver nela um colégio horrível."

"Saindo de casa pego uma rua tranqüila, que é a rua do meu bairro, uma rua com muitas árvores e casas. Sigo em frente até chegar à Av. Guilherme Drumond, uma rua muito movimentada, com muito trânsito, com um farol muito demorado, mais ou menos 3 (três) minutos. Depois que passo pelo farol, viro à direita, Av. Francisco Morato, sigo um pouco em frente e pego a I à direita; após algum tempo pego a Eliseu de Almeida, e assim, sigo mais um pouco adiante e entro no Colégio Ítaca."

"Atravesso a Av. Pirajussara. $\bigcirc$ cheiro do córrego impregna o ar. Não há sombra, o lixo está jogado no terreno baldio ao lado da calçada. Há um esqueleto do que foi um cachorro, também em meio ao lixo. Os carros atropelam o que está no caminho, numa pressa incessante. $\bigcirc$ barulho é sempre o mesmo. Tudo é cinza, sujo e caótico. Sigo andando até o corpo de bombeiros. A paisagem pouco muda. Começam agora as ladeiras. A zona residencial do Butantã é de casas geminadas, todas iguais. Passo pela praça que parece ser uma fraca exceção, quase definhando como o resto. Chego ao meu condomínio de muros altos e brancos perpendiculares à calçada suja por fezes."

"Eu venho para a escola por 2 (dois) diferentes caminhos, dependendo do dia: pela Francisco Morato e pela Eliseu de Almeida. No segundo é o que eu presto mais atenção; de qualquer forma, ambos começam na Av. Rebouças, onde estão sendo feitas as obras para a construção do túnel. Sigo pelo desvio, desgastado devido ao intenso tráfego de carros e ônibus graças à obra. Vou até o fim da Rebouças e entro para chegar à Eliseu, a mesma de acesso à Raposo Tavares. Uma vez na Eliseu, o caminho é reto. Percebo a necessidade de recapeamento na avenida, e muitas oficinas ou qualquer tipo de comércio referentes a carros. Se houver circulação de ônibus é muito escasso, diferente do tráfego de caminhões. 
Há, mais à frente, uma favela e uma passarela. A avenida por onde eu venho é oposta à rua do colégio, por isso é necessário fazer o retorno mais adiante."

"A rua em que moro termina na avenida que nos atinge aqui no Ítaca, portanto não há muitos pontos dignos de atenção a não ser a minha casa onde começa o trajeto, o Shopping Butantã, o retorno que tomo depois da escola e a escola em si. Mas há alguns pontos que nos chamam a atenção, não por serem bonitos, como o canteiro central na área perto do shopping que é particularmente bem cuidado, a rua fechada da escola pública e a encruzilhada perto do posto."

"Saio de casa, à esquerda vejo a Paraisópolis, segunda maior favela de São Paulo. Muitas ruazinhas, à esquerda e à direita, depois chego à Giovanni Gronchi. Entro à esquerda, novamente passo por outra parte da favela. Depois passo pelo Cemitério Ghetsemani, algumas ruas à frente passo por uma casa de sinuca com uma Igreja do Reino de Deus, Francisco Morato, João XXIII e enfim chego ao Ítaca."

"Saio de casa e entro numa rua de terra, na qual não há prédios nem casas, é tipo um grande terreno baldio. Depois entro numa rua pouco movimentada, cheia de prédios, casas e comércios, vou até o fim dela e entro numa avenida bastante movimentada. Logo após entro na avenida, viro na primeira rua à direita, uma rua que só tem casas, desço a rua inteira e viro à esquerda, e entro na avenida da escola, que de manhã é bastante movimentada. Passo pelo Jóquei, pelo Planeta Bola e chego na escola. Durante o percurso não há área verde."

A proposta final do curso foi que eles elaborassem um projeto para a quadra da Avenida Pirajussara onde se localiza a escola, e representassem-no com uma maquete. $\bigcirc$ primeiro exercício foi a observação do local e o levantamento de seus aspectos positivos e seus problemas. Rapidamente levantaram apenas problemas, afirmando que não havia aspectos positivos:

- velocidade muito alta dos veículos

- $\quad$ ausência de faixa de pedestres

- $\quad$ ausência de passarela de pedestres

- barulho excessivo de caminhões

- poluição por veículos 
- barulho de heliponto próximo

- canteiro central da avenida sem passagem para pedestres

- canteiro central com vegetação pobre, maltratada e sem manutenção

- $\quad$ pichação em muros e paredes

- mau cheiro do rio

- $\quad$ falta de linhas de ônibus que atendam a diferentes pontos da cidade

- $\quad$ ausência de sinalização para pedestres e automóveis (faixas de rolagem, p.ex.)

- ausência de sinalização indicando existência da escola

- asfalto irregular

- $\quad$ pintura dos muros gasta

- bueiros abertos (perigo)

- calçada estreita, 'fumacenta' e com buracos

- acúmulo de lixo na calçada, e

- $\quad$ ausência de iluminação.

A partir desse levantamento dividiram-se em grupos de quatro ou cinco para elaborar propostas de melhoria daquela quadra. As fotos das maquetes infelizmente se perderam, mas seguem abaixo os itens levantados quando da apresentação de suas maquetes para o resto da classe:

Grupo I: calçadas mais largas, canteiros com vegetação, fechamento do rio, "senão fede", radar escondido.

Grupo 2: mais árvores, farol, lombada eletrônica, horário para tráfego de ônibus, pontos de ônibus com placas contendo horários e itinerários, aumento do número de paredes grafitadas (não pichadas).

Grupo 3: calçadas mais largas, mais postes de iluminação, respiradouros do rio continuam.

Grupo 4: disponibilidade de transporte (ciclovia e metrô), controle de tráfego, faixas de pedestre. 
Grupo 5: volta ao passado/sociedade alternativa: monumento ao automóvel, descanalização e renaturalização do córrego, implantação de via férrea (trem como meio de transporte), cultivo de vegetais comestíveis e flores às margens do córrego.

Grupo 6: implantação de vegetação ornamental (melhor e mais bonito), fechamento do rio para limpeza e atenção aos pedestres: calçada mais larga e detector de velocidade na faixa de pedestres.

Podemos agrupar as propostas nos itens abaixo:

- $\quad$ transporte: metrô, ciclovia, ônibus, trem, pedestres repensar em como reorganizar a avenida em função desses modos de circulação.

- áreas verdes: organizar o canteiro central pensando realmente no seu desenho, tipo de vegetação a ser utilizado, caminhos, etc.

- córrego - foram apresentadas 3 opções:

- manutenção dos respiradouros como estão;

- fechamento dos respiradouros;

- renaturalização do córrego.

\section{Avaliações}

Buscando compreender melhor o processo e, ao mesmo tempo, encontrar caminhos para solucionar alguns problemas em experiências futuras, foi pedido aos alunos que fizessem uma avaliação do curso, fazendo algumas perguntas para orientá-los. Optou-se por apresentá-las todas antes das considerações finais, pois elas forneceram subsídios importantes para sua elaboração. 


\section{Fale um pouco sobre os aspectos positivos do curso}

"O curso de projeto de arquitetura teve aspectos importantes, quando observamos a palestra da Guila ${ }^{15}$ sobre Israel e como os aspectos políticos podem influir tanto na urbanização de um local."

"Um dos aspectos positivos do curso foi "descobrir" sobre o que realmente está acontecendo em Israel."

"Vimos alguns problemas de partes do mundo, discutimos sobre eles e fizemos a maquete. Essas aulas foram as melhores."

"A idéia da maquete até que foi legal. A palestra sobre o muro da Palestina."

"O curso foi bem legal, a proposta me interessou e discutimos temas bem legais, como, por exemplo, o da palestra sobre Israel."

"Eu acho que o trabalho da maquete foi muito legal, a idéia também foi muito boa, de fazer a rua dos seus sonhos, a rua ideal."

"O que foi bom no curso foi a discussão sobre os problemas da Eliseu, pois isso me fez perceber o que pode ser melhorado e eu pude analisar uma avenida por onde eu passo todos os dias."

"Algumas atividades como a do percurso, conhecimento da cidade. Aulas menos convencionais, como aquela em que ouvimos músicas e atividades dinâmicas como as aulas em que fizemos a maquete. A palestra [de Guila Flint] foi excelente."

"O curso proporcionou coisas boas: leituras de textos interessantes, que abordavam assuntos legais, discussão de problemas ambientais em geral, palestra abordando um assunto atual e relacionado às cidades."

${ }^{15}$ Guila Flint é jornalista brasileira, correspondente da seção Brasil da BBC em Tel Aviv, Israel; ela fez uma apresentação sobre, e discutiu com os alunos, as questões territoriais em Israel, mostrando imagens de paisagens locais, inclusive e principalmente as do muro que está sendo construído para, supostamente, proteger o território israelense de terroristas palestinos. 
"A saída e a proposta da maquete ideal são bons projetos a serem realizados, assim como os slides e os vídeos; o aspecto especialmente bom foi a palestra sobre a muralha que está sendo construída."

"O curso serviu como uma base para o conhecimento, ainda que pouco aprofundado, e a noção de espaço que habitamos."

"É possível por meio de imagens e textos encontrar a "cidade escondida", entender o estado atual da cidade, o parque e como melhorá-los."

"Como aspecto positivo aprendi a reconhecer e a tentar solucionar problemas de infra-estrutura de nossa cidade. E também gostei muito da questão do muro de Israel."

"As aulas usadas para a fabricação da maquete foram legais, pois não houve discussões ${ }^{16}$. A palestra feita pela Guila, na minha opinião, foi a melhor, pois pudemos entender um pouco mais sobre o que está acontecendo no resto do mundo. A aula gasta para observação do quarteirão foi interessante, pois paramos para pensar cinco minutos e descobrimos vários problemas nos quais nunca nós tínhamos pensado. Não imaginei que este trecho da avenida tivesse tantos problemas."

"Gostei dos trabalhos que realizamos fora da sala, que eram mais práticos e não muito teóricos (tipo a discussão do texto sobre a rua do Rio de Janeiro ${ }^{17}$ ). Gostei também da palestra, porque acho que foi uma aula diferente e me informei sobre esse assunto."

"Eu gostei da parte que analisamos as condições desse quarteirão e fizemos a maquete porque isso mostrou que realmente tem muito a ser melhorado. Gostei também da palestra da Guila, pois nos mostrou a realidade em Israel."

\footnotetext{
${ }^{16}$ Aqui o aluno se refere a discussões referentes à dinâmica do grupo.

17 Texto de jornal - Anexo II
} 


\section{Fale um pouco sobre os aspectos negativos do curso}

"O curso teve aspectos ruins por ser muito repetitivo com esse tema, e também a maquete feita não teve muita utilidade, já que as propostas tinham sido feitas."

"O único aspecto negativo do curso é a repetitividade da aula."

"Nas aulas teóricas vocêl8 se desconcentra muito fácil e isso atrapalha a compreensão. O percurso de casa à escola, os desenhos de lugares da escola, o mapa da escola, as músicas não foram muito "marcantes"; talvez não houve uma discussão muito boa."

"Faltou ter uma visão prévia do que iria ser o curso, pois eu achava que íamos ver melhor o que era e conhecer os aspectos de arquitetura; acho que o curso ficou muito preso à paisagem. E pouca paciência ${ }^{19}$, o que às vezes cansou quem prestava atenção."

"O único aspecto considerado por mim como negativo foi a falta de paciência da professora em horas não necessárias."

"Eu acho que o curso ficou muito parado, cansativo demais. Também acho que a professora se esforçou muito para melhorar o curso, mas muitas vezes ela brigava com os alunos por motivos inúteis, e com isso só deixava a aula cada vez mais chata."

"O curso foi muito pouco produtivo, não teve resultado final."

"Amplia a noção de espaço urbano e sua problemática social. Liga a cidade a problemas atuais, como a segregação que ocorre entre os judeus e palestinos, oferecendo a possibilidade de entender como isso ocorre."

"O curso poderia ter um enfoque mais centralizado, menos disperso. Poderia se utilizar mais, por exemplo, da observação de problemas urbanos e como foram

\footnotetext{
${ }^{18}$ Aqui o aluno(a) se refere a mim.

${ }^{19}$ Idem.
} 
resolvidos. As condições dos países do $3^{\circ}$ mundo deveriam ter sido mesclados com o estudo do espaço. O curso deveria, enfim, ter sido mais pragmático."

"Houve aulas muito convencionais, com leitura de texto. Aulas depois do almoço já trazem um certo desagrado e repetir o que se fez nas demais aulas não é agradável, como por exemplo leitura de texto. Os desentendimentos que logo foram resolvidos com conversa."

"Porém houve aspectos negativos: acho que algumas atividades não se ligaram; não compreendi muito bem através das atividades realizadas, o objetivo principal do curso; e poderia haver mais conteúdo relacionado às cidades em geral e especificamente sobre São Paulo."

"Os assuntos parecem ser sem nexo e continuidade, sendo assim pulando de assunto para assunto nunca aprendemos nada a fundo e pouco observamos, e a pouca paciência por parte da professora também impede o aprendizado já que os alunos ficam acuados."

"Houve dificuldades de relacionamento de alguns alunos com a professora. O estilo de ensino da professora possui uma dinâmica, porém não habitual; por esse motivo alguns acabaram não levando nada em matéria de aprendizado. O curso foi pouco aprofundado devido ao tema e devido a alguns impasses, que acabaram por diminuir o número de aulas."

"Por ser um curso de 16 aulas não é possível ter grande aprofundamento nos temas. Algumas aulas muito "jogadas" sem ligação umas com as outras atrapalharam o andamento e entendimento do curso. A maquete, pode-se dizer, foi um total desperdício de aulas, que poderiam ser usadas para aulas mais interessantes." 


\section{"Aprendi com a primavera a deixar-me cortar e voltar sempre inteira."}

Clarice Lispector

\section{Da conduta da professora:}

"No meu ponto de vista houve total falta de controle sobre a sala. Lembrando minha professora da $3^{a}$ série, tentava controlar as atitudes dos alunos e não sua conduta, "pegando no pé" de alguns alunos e em certos momentos sendo muito repetitiva e cansativa com broncas DESNECESSÁRIAS, mudando pessoas de lugar, controlando as atitudes, criou mal estar geral."

"Como aspectos negativos, o fato de que o curso não se aprofundou muito e a única coisa "prática" que fizemos foi a maquete do quarteirão de nossa escola. Em relação à professora, acho que ela perde a calma com os alunos muito rapidamente e talvez não saiba lidar direito com uma classe como a nossa."

"Houve várias discussões (aluno-professor) o que atrapalhava as aulas. Sinceramente eu não entendi a razão da música do Paulo Miklos. Não encontrei uma ligação entre elas e o curso. Não entendi a razão da entrega do trecho da entrevista com o ex-prefeito de Bogotá."

"Não gostei das aulas mais teóricas. Achei que a professora umas vezes perdeu a calma muito facilmente, mas também achei que o curso foi atrapalhado por pessoas que não estavam interessadas nele. Acho que foi pouco o tempo que o curso durou e que se tivéssemos tido mais tempo talvez pudéssemos desenvolvido melhor alguns trabalhos."

"Aspectos negativos são que no começo houve um problema de relacionamento e que não foi possível fazer tudo o que se tinha proposto, pois a proposta em si era boa." 


\section{O que ficou para você depois de participar deste curso?}

"Ficou o conhecimento expandido sobre o muro de Israel e também a proposta muito interessante do ex-prefeito de Bogotá, pois vimos que isso seria uma boa solução para essa qualidade de vida melhor."

"De agora em diante eu costumo prestar mais atenção no espaço público."

"Para mim ficou a questão do muro de Israel e o texto do Peñalosa."

"Um pouco mais de informação sobre o muro de Israel. Como o ser humano destrói muito a paisagem e como São Paulo já foi muito mais bonita."

"O que foi mais proveitoso para mim sobre o curso foi a palestra sobre Israel."

"Sei lá, mas eu acho que a reflexão sobre os problemas da cidade foi interessante. Não digo que possa ajudar futuramente, mas foi legal nós discutirmos sobre esse assunto."

"Depois do curso o que ficou foi o assunto sobre Israel, a palestra que foi muito interessante."

"Tenho um pouco mais de noção referente à cidade, sobre seus aspectos, características e problemas que, agora, sei que têm determinadas soluções (que não são fáceis). A palestra também ficou e questões referentes ao muro e suas divisões podem ser comparados até mesmo com São Paulo."

"Ficou para mim do curso uma melhor percepção dos problemas das cidades em geral. Talvez antes de ter feito o curso eu não percebesse tantos problemas e não tentasse ver maneiras de resolvê-los. A proposta do curso é boa, mas, sinceramente, acho que faltou uma continuidade e ligação entre as atividades realizadas. Porém, obtive muitas informações através dos textos."

"Muito aprendi sobre o Iraque (sic) e a muralha da vergonha e um pouco também sobre nossos próprios problemas aqui em nossa rua; um pouco mais poderia ter sido visto e aprendido, mas há a falta de vontade, admito." 
"A mim ficou pouca coisa, é uma pena, porém, ficaram alguns conceitos básicos sobre cidades, espaços, dimensões. O curso foi pouco desenvolvido e atípico a outros projetos."

"Mais que o aprendizado, a lembrança de um carrasco."

"Esse curso serviu talvez, como um aprendizado extra. Aprendi um pouco mais sobre cidadania e áreas públicas e a reconhecer problemas e formular soluções."

"Imaginava um curso diferente, onde fôssemos trabalhar somente a cidade de São Paulo. Achei o curso bastante interessante no geral. Entendi melhor como 'funciona' uma cidade e o mundo."

"Como as cidades mudam, a falta de conscientização com espaços públicos, como os espaços mudam segundo os interesses de cada sociedade."

"Ficou bastante a compreensão da realidade do que está acontecendo na Palestina, também, os vários problemas da cidade de São Paulo (principalmente deste quarteirão)."

\section{Algumas Considerações}

A proposta inicial do trabalho desviou-se de seu caminho em função de uma dificuldade imensa na criação de vínculo com os alunos, que identificaram uma dificuldade em trabalhar num ambiente com muitos estímulos. "Você se desconcentra com qualquer coisa", era a fala mais freqüente deles. Essa dificuldade realmente existiu, foi trabalhada e melhorada, através de conversas regulares, inclusive com a participação da coordenadora; no entanto não foi alcançado um ambiente adequado aos trabalhos, nem um bom ritmo para que eles se desenvolvessem. A realidade dos jovens hoje tem uma dinâmica muito diferenciada, e esta é uma questão fundamental no trabalho com eles. Diferentemente de gerações anteriores, há uma intimidade muito grande com a velocidade e a concomitância de atividades - eles produzem falando com o colega, ouvindo música no i-Pod, andando de um lado para o outro da sala, atendendo ao telefone celular: 'tudo ao mesmo tempo, agora'. Não os incomoda o fato de várias pessoas 
falarem ao mesmo tempo; não os atrapalha a simultaneidade de ações, de atividades. Há que se prestar muita atenção a isso para não fazer propostas anacrônicas. A concentração, o foco em apenas um assunto, não é uma característica primordial da juventude hoje em dia; a quantidade de informações e estímulos que o mundo lhes proporciona é enorme e essa geração cresceu aprendendo a lidar com isso. O seu tempo não é o do silêncio para ler, da disciplina férrea para o estudo, da aprendizagem descolada do ensino ("eu ensinei, mas ele não aprendeu!'), e sim de interatividade.

Quanto às descrições dos percursos casa-escola, podemos inferir algumas coisas, mas algo se destaca: é tudo muito monótono. Talvez pela forma como o exercício foi proposto - "descreva o caminho de sua casa até a escola" - eles acabaram por fazer descrições muito desprovidas de emoção. Nenhum deles evidenciou algo interessante, algum elemento de realce, alguma experiência significativa pela qual tenha passado nesse caminho. A forma da proposta foi equivocada; talvez uma proposição diferente estimule mais a memória e a memória da percepção: "conte um dia de sua vinda de casa para a escola, apontando os lugares por onde passa e o que acontece com você durante esse percurso". A intenção inicial era mapear espaços livres e discutir suas características a partir de elementos de vivência dos alunos; este seria um ponto de partida para pensar seus lugares de vida, mas a forma da proposta precisa ser repensada.

A elaboração da maquete do quarteirão da escola teve inúmeros aspectos positivos: ocorreram discussões acaloradas sobre os problemas levantados no espaço analisado, deixando ver que eles refletiram sobre o assunto; pode-se notar a clareza com que os jovens percebem os problemas, e a facilidade e criatividade que têm para propor soluções. À primeira vista essas soluções podem parecer simplistas, mas são soluções utilizadas em algumas cidades como Bogotá, por exemplo, que através delas conseguiu transformar seus espaços públicos em um tempo relativamente curto; foi, por exemplo, feita a implantação de ciclovias e foram implementadas restrições ao tráfego de veículos automotores.

O material utilizado foi: placas de isopor, papel crepom, papel espelho, caixas de fósforo, palitos de sorvete e de dente, canetas hidrográficas, tesoura e 
estilete; ele deveria ter sido mais processado, mais elaborado. Seria necessário trabalhar com mapas da região, fotos aéreas, plantas cadastrais, e outros materiais que apresentassem um desafio para eles. $\bigcirc$ incentivo com relação ao acabamento e à finalização dos trabalhos, foi fraco; esses jovens respondem melhor a desafios complexos.

Devidamente preparada, a metodologia de construção de maquetes é bastante adequada para a discussão de espaços livres pois ela facilita sua compreensão e a discussão de questões relativas a ele tais como ocupação, uso, estética, elementos naturais e construídos, entre outras.

Um prosseguimento adequado seria uma pesquisa sobre cada um dos três temas levantados por eles durante a confecção das maquetes - transporte, áreas verdes e córrego - para se conhecer projetos, tecnologia para a solução de alguns desses problemas, propostas inovadoras, para ampliar o conhecimento sobre vegetação, dinâmica das águas e outras questões que os alunos considerassem importantes; visitas a locais onde houvesse soluções interessantes para problemas similares. Em seguida, apresentação das pesquisas para todo o grupo para que estas alimentassem a reformulação das propostas. E ao final, a elaboração de uma única maquete/proposta feita por todo o grupo. Desta forma seria inevitável a discussão entre diferentes posições, estimulando a fundamentação de cada uma das idéias.

Pode-se perceber claramente pelas avaliações que houve um sério problema de relacionamento e dinâmica que atrapalhou o andamento do curso, mas que, apesar disso, muitos alunos puderam destacar aspectos positivos como o desenvolvimento da percepção com relação ao ambiente em que vivem, que era um dos objetivos do curso. A avaliação feita pela orientadora do Ensino Médio após a leitura das avaliações dos alunos foi importante pelo olhar externo ao processo: "... me chamou a atenção que os meninos ${ }^{20}$ têm consciência de que saíram enriquecidos e com outro olhar, e mais críticos em relação ao espaço..."

\footnotetext{
20 "os meninos" é uma maneira de se referir aos jovens e crianças em geral; não se refere apenas aos do sexo masculino.
} 
A dinâmica foi muito conturbada e o grupo não trabalhou bem; não conseguimos estabelecer uma história para o grupo, uma linha clara de trabalho, uma boa dinâmica, e isso tomou um tempo muito grande nas nossas conversas semanais. Por isso, as avaliações dos alunos e da coordenadora foram importantes. Elas permitiram a observação de aspectos positivos do processo de trabalho; foi também possível verificar que alguns dos objetivos do curso foram alcançados. Pode-se constatar que o conteúdo das aulas não foi equivocado - os alunos e alunas citaram inúmeras questões relativas à cidade em suas avaliações, demonstrando interesse por elas, entretanto, a forma de apresentação desse conteúdo foi inadequada.

Caberia, na proposta da execução da maquete, uma exigência maior nas discussões dos problemas encontrados e nas soluções apresentadas para eles, um estímulo para se obter resultados técnicos mais detalhados. $\bigcirc$ potencial dos jovens é muito alto, sua criatividade, imensa, sua energia muito grande, sua capacidade crítica, bastante aguçada. Pode-se e deve-se desafiá-los a pensar mais, a discutir mais, a produzir mais.

\section{PROGRAMA ESCOLA QUE VALE ${ }^{21}$}

Este programa é coordenado pelo CEDAC (Centro de Educação e Documentação para a Ação Comunitária) que "é uma OSCIP, cujo foco é promover ações que favoreçam a aprendizagem e a interação das comunidades em que atua."22 Em 2003 fui convidada a trabalhar como 'oficineira' no Programa; o público alvo eram professores da rede pública municipal de Marabá, Pará. Incluídas na área de Artes do programa, foram propostas oficinas de Leitura de Paisagem, conforme abaixo.

\footnotetext{
21 idem

22 do site www.cedac.org.br
} 


\section{Primeira oficina - novembro de 2003}

Objetivo: Despertar a consciência e desenvolver a percepção com relação à cidade onde se vive.

$$
\text { Relatório }^{23}
$$

$1^{a}$ manhã

Eram cinqüenta e dois professores, em sua grande maioria mulheres - das áreas urbana e rural -, sendo que muitos trabalham com várias séries e idades na mesma classe. A primeira atividade foi a apresentação de cada um.

Logo foi possível perceber que o planejamento inicial, preparado em São Paulo apenas com informações vagas sobre as pessoas e o local, se mostrava inadequado e precisou ser reestruturado. Como atender a essa turma? A proposta é olhar para a paisagem, ver a paisagem, prestando atenção nela. A ferramenta de trabalho, o desenho.

"Quem desenha, já desenhou, gosta de desenhar?" Só uma pessoa levantou a mão. Foi explicado que nosso trabalho seria "prestar atenção ao lugar em que se vive" e que a memória seria nossa ferramenta primeira. $\bigcirc$ exercício inicial foi uma descrição oral do lugar de trabalho de cada um, inclusive do entorno da escola. Alguns deram descrições bastante precisas, detalhadas, outros menos; mas foi um estímulo para que começassem a se lembrar, visualmente, de seus lugares de trabalho. "Fechem os olhos e tentem se lembrar do que vocês vêem quando estão saindo da escola, quando andam por ali, quando olham para os lados."

Como forma de aproximação ao desenho, com lápis e papel, foi proposto que desenhassem em uma folha de papel sulfite A5:

\footnotetext{
${ }^{23}$ Esta oficina ocorreu nos dias 7 e 8 de novembro de 2003 e contou com a colaboração da estagiária local, Natacilda Barros.
} 
$1^{\circ}$ - apenas linhas retas que não se cruzassem;

$2^{\circ}$ - apenas linhas curvas que não se cruzassem;

$3^{\circ}$ - apenas linhas retas cruzando-se;

$4^{\circ}$ - e que finalmente colorissem as formas surgidas a partir dos cruzamentos de linhas.

A intenção desse exercício era mostrar que todos podem desenhar. Atentou-se para a fato de que os resultados não seriam avaliados e que eram apenas um exercício, um aquecimento. É sempre preciso lembrar aos participantes "que o objetivo da oficina não é "revelar artistas", mas sim experimentar processos criativos sem julgamentos estéticos. Lembrar que 'saber' desenhar não é um prérequisito da oficina, ao contrário da vontade de aprender coisas novas e de participar, estes sim, nossos verdadeiros pré-requisitos." Alex Ceverny ${ }^{24}$

Ao chegar perto de uma professora, vi que ela amassou o seu desenho; pedi para vê-lo. "Por que você está jogando seu trabalho fora?" "Ah... não está bom." Solicitei que ela o desamassasse, olhei e disse: "Está ótimo! É isso mesmo. Continue aqui mesmo, não precisa fazer outro." Apenas esse reforço, essa fala afirmativa, tirou a insegurança dessa professora, que passou a desenhar mais livre e alegremente. No terceiro exercício começaram a se divertir; formas aparecendo, cores se opondo, se assemelhando, cada um encontrando seu espaço.

Ao final, todos os trabalhos foram colocados na parede; a partir dessa observação conversamos sobre a atividade. Seguem algumas falas:

- "descobri o artista dentro de mim"

- "descobri que sou artista"

- "são todos diferentes"

- "quanta coisa!"

- "Olha como ficam bonitos todos juntos!"

${ }^{24}$ Alex é 'oficineiro' do CEDAC e esta citação é de um de seus relatórios de oficina. 
- "no início da nossa conversa só uma pessoa disse que desenhava, lembram-se?" 25

Reuniram-se em grupos por escolas, para representar, no papel, a escola em que trabalhavam e seu entorno, procurando visualizar esse lugar, pensar e anotar o que gostariam de representar no papel.

$1^{a}$ tarde

O material utilizado foi: papel kraft, papel sulfite, papel espelho, lápis de cera, giz pastel, canetas hidrográficas, tesoura, cola em bastão, lã, fitilhos. Houve muita discussão sobre como proceder, a posição de cada elemento, as distâncias, as vistas (aérea, perspectiva, frontais), as proporções, os tamanhos, as posições.

Estávamos trabalhando no pátio de uma escola e seus corredores e os professores foram estimulados a olhar os trabalhos dos colegas. Um professor disse "ah, então vou roubar o trabalho de alguém"; aproveitou-se para conversamos um pouco sobre troca de informações, intercâmbio de idéias. Uma professora queria desenhar frutas, "mas eu não sei". Foi estimulada por perguntas tais como "qual fruta você gostaria de desenhar?", "uma jaca", "e como é uma jaca?, de que cor?, de que formato?". O resultado foi que ela fez (desenhou e recortou) a tal jaca, um caju e outras frutas. E adorou! Depois quis fazer uma horta, que foi desenhada depois da sugestão para que ela fosse ver a horta do outro grupo. Abaixo, alguns resultados.
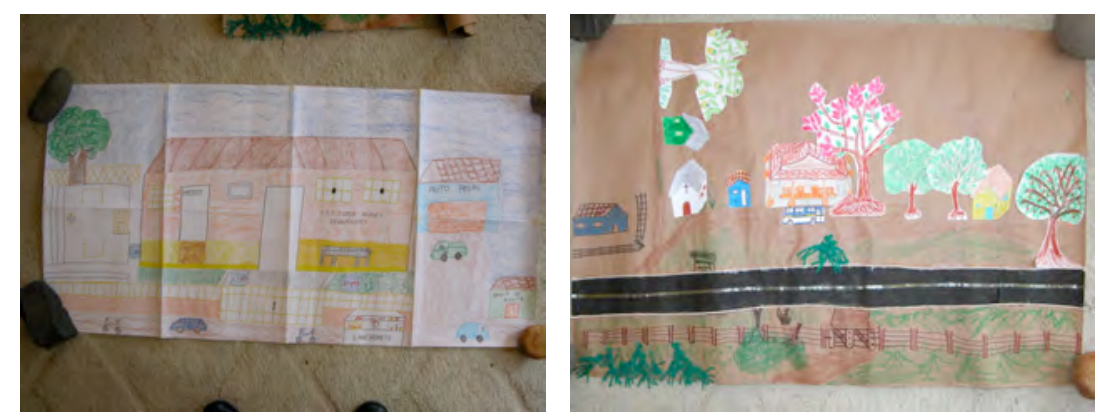

${ }^{25}$ Observação minha. 

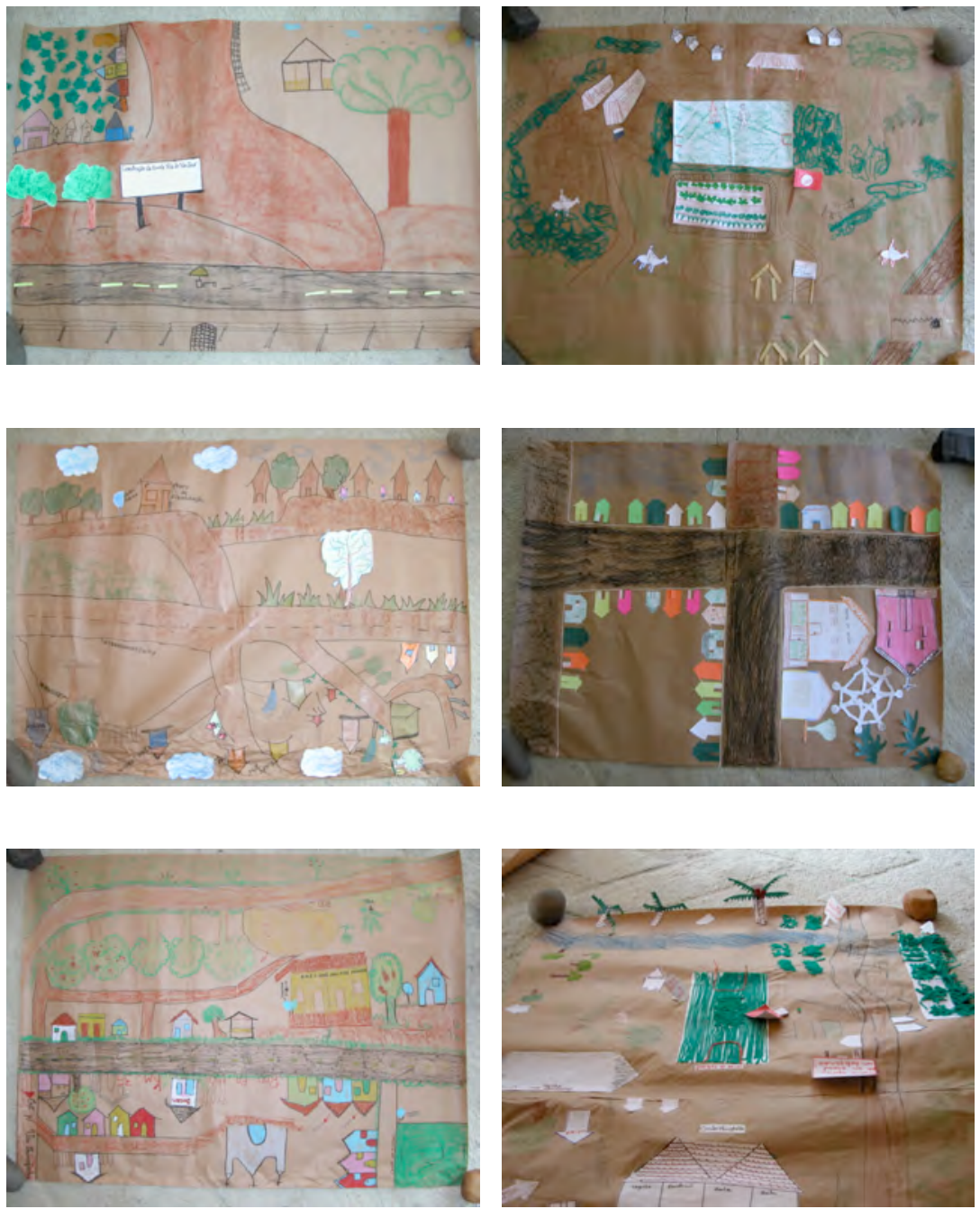

Ao final da tarde conversamos e algumas questões foram levantadas:

- a dificuldade de se trabalhar em grupo;

- $\quad$ a riqueza de se trabalhar em grupo "porque cada um lembra de uma coisa";

- a dificuldade de se lembrar da paisagem de um lugar onde "a gente trabalha todos os dias mas não presta atenção a ele, aos seus detalhes";

- a satisfação de ter conseguido fazer o trabalho;

- a diferença de representação do mesmo lugar por dois grupos diferentes - "é incrível como cada um percebe as coisas de um jeito diferente". (havia dois grupos da mesma escola) 
$2^{a}$ manhã

A proposta era observar a paisagem do entorno da escola onde estávamos trabalhando.

O primeiro exercício propunha-se a oferecer algum subsídio para o desenho de observação: olhar para o que está à sua frente, tampar um dos olhos com a concha da mão e acompanhar linhas, com o dedo indicador, como se se estivesse passeando o dedo por sobre as linhas - quaisquer linhas que se escolhesse. Atentar para o fato de que as linhas de objetos distantes se encontram com as de objetos mais próximos; atentar para a diferença de linhas de objetos construídos e objetos naturais; atentar para o fato de que algumas linhas a gente sabe que existem mas não as vê (p. ex. a cumeeira de um telhado que estava escondida pela estrutura de cobertura do pátio onde trabalhávamos). Demorou um pouco, mas logo se fez silêncio e os dedos começaram a passear pelo ar.

O segundo exercício propunha se fazer esse mesmo "passeio pelas linhas", apenas desta vez olhando para as linhas e passeando com o lápis sobre o papel; bem devagar; e sem olhar para o papel. $\bigcirc$ atendimento individual foi fundamental, pois eles eram muitos e a instrução dada para todos não funciona para alguns.

O principal exercício do dia era a representação da Praça Duque de Caxias, que fica a uns 50 metros de onde estávamos. A praça é retangular, rodeada de estabelecimentos comerciais e alguns institucionais; tem muitas árvores, canteiros, praça de alimentação(!), parquinho, coreto, laguinho com carpas e um busto do Duque de Caxias. Duas das ruas que desembocam nela dão vista para o rio Tocantins. Num primeiro momento fomos para a praça caminhar e olhar, observando alturas, cores, texturas, nomes, tamanhos, formatos, distâncias, pessoas, construções, vegetação, e o que mais se apresentasse.

Em seguida, foi proposto que escolhessem algum trecho da praça para desenhar a partir da observação no local. Novamente o atendimento individual foi importante pois, conforme esperado, houve muita dificuldade, mas aos poucos, referindo-se ao exercício do olho, feito pouco antes, as pessoas foram descobrindo 
possibilidades. Houve quem desenhasse em perspectiva - descoberta! Alguns desenhos eram de detalhes, outros de uma vista mais ampla; uns mais soltos, outros menos, mas todos desenharam.

Voltando para a escola, conversamos sobre a atividade. As observações foram semelhantes às do dia anterior. Então reuniram-se em grupos de quatro ou cinco para fazer a representação da praça, tendo como base, papel kraft. $\bigcirc$ material, o mesmo do dia anterior.

"Pode usar o próprio desenho, pode recortá-lo?, "Pode repetir o mesmo desenho (no caso de bancos, árvores ou outro elemento que se repetisse na paisagem)?"

"Pode - e deve - não apenas isso, mas também olhar os desenhos dos colegas porque isso amplia nossas informações; pode voltar à praça para olhar algo novamente. Podem começar." Abaixo, representações da Praça.
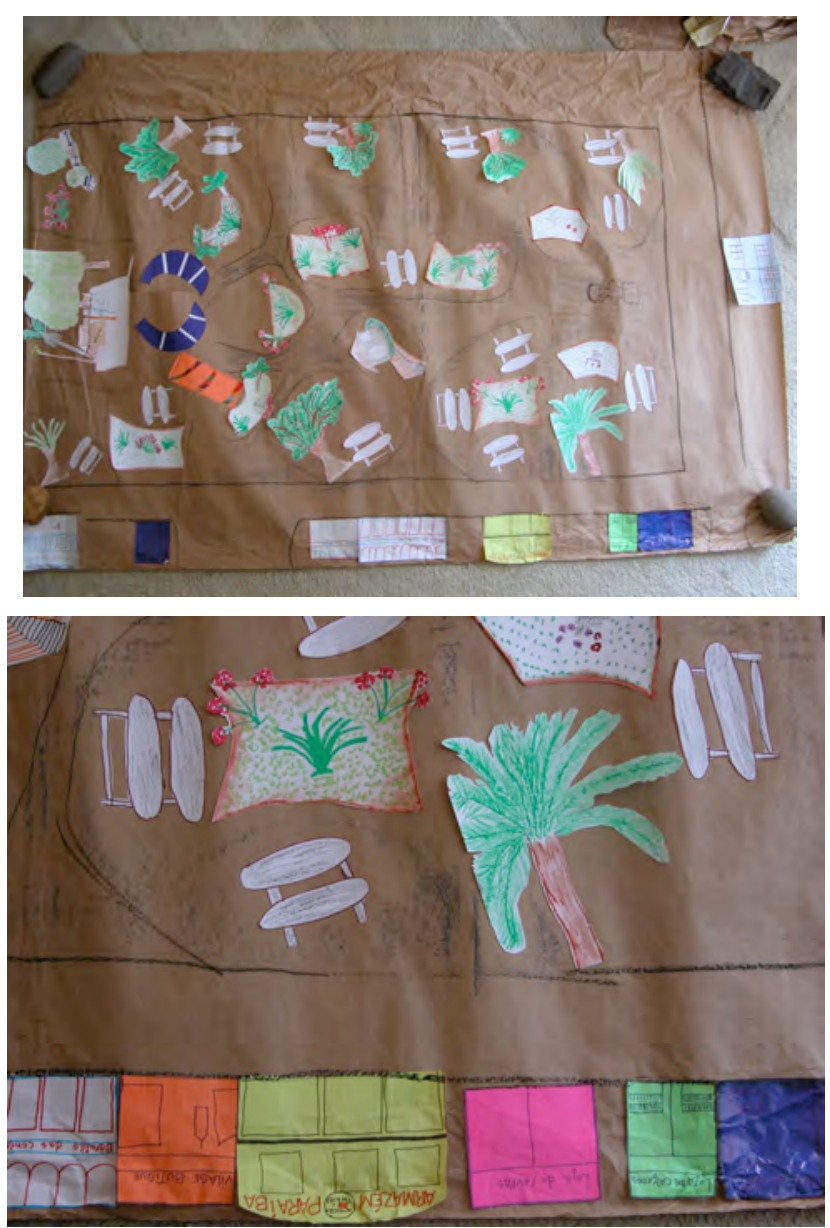

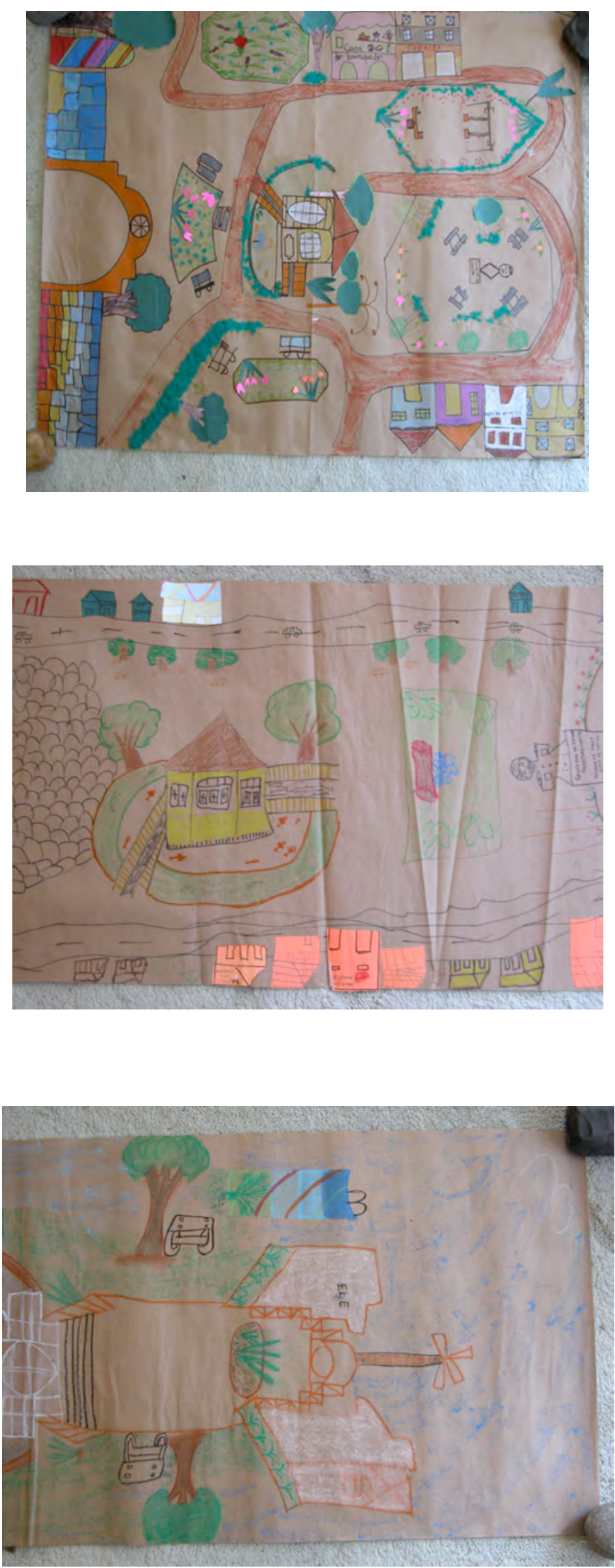

Paisagem como encantamento: experiências $\diamond 100$ 

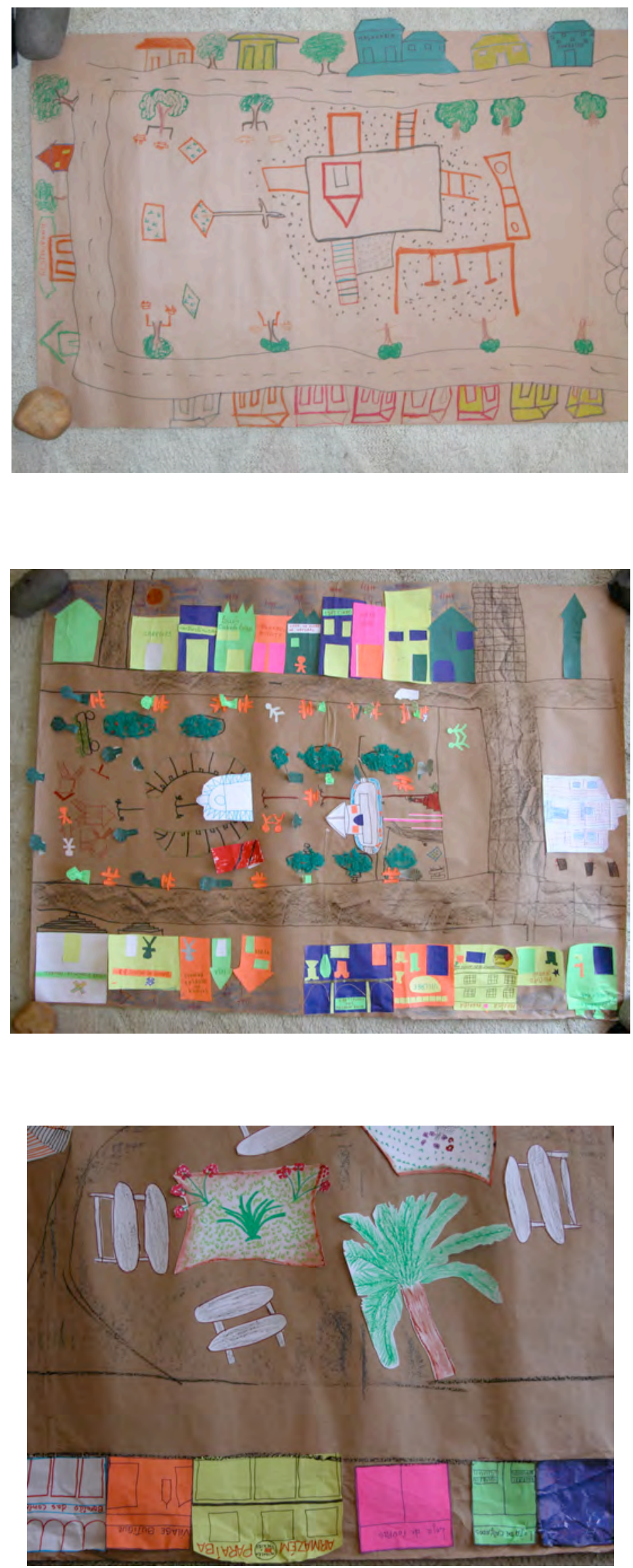

Paisagem como encantamento: experiências $\diamond 101$ 


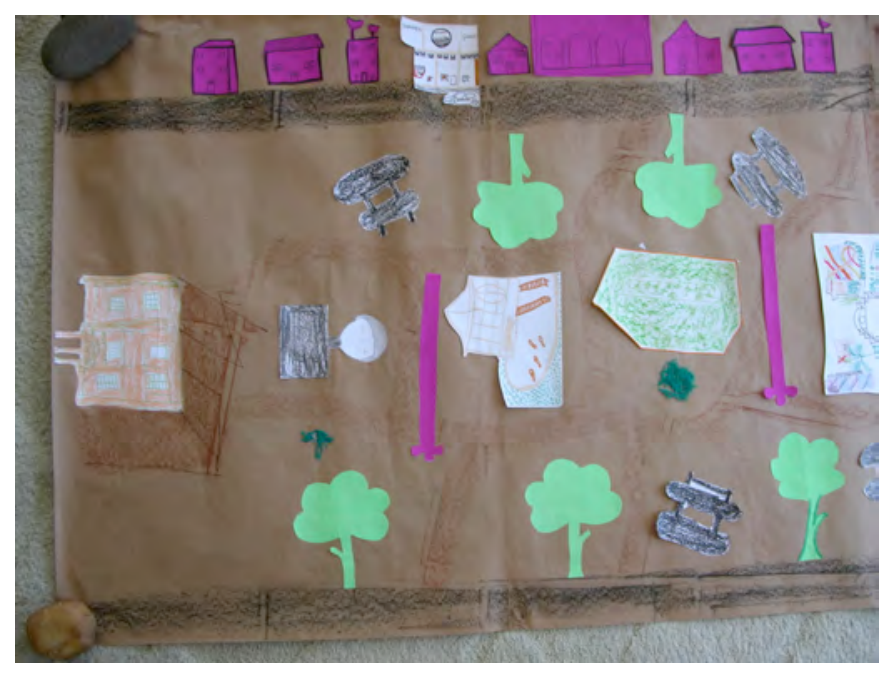

Os grupos trabalharam bastante envolvidos, procurando reconstituir mentalmente a estrutura da praça, a partir de perguntas que estimulassem a recuperação das imagens: "onde ficam as árvores?", "e os postes de iluminação?", "onde fica a Câmara Municipal?" "o que mais há na praça?". Alguns realmente voltaram à praça para re-ver algumas coisas. Um grupo ficou discutindo se havia 2 ou 3 mangueiras e após uma ida rápida até lá: “Tem 8!!! E a gente nem tinha visto!"

As soluções para a representação de cada elemento da praça foram tantas quantos eram os grupos e/ou pessoas trabalhando.

\section{$2^{a}$ tarde}

Na volta do almoço, estavam todos sentados ou deitados no chão, recortando, desenhando, colando, conversando - todos trabalhavam, muito encantados com a própria produção. Ao final, guardamos o material, expusemos todos os trabalhos foram expostos no chão para serem observados.

Como resultado de uma avaliação oral e, em seguida, escrita, alguns comentários valem a pena ser notados:

- "a gente muitas vezes não presta atenção ao que existe à nossa volta; tem tanta coisa!";

- $\quad$ "como é bom e produtivo trabalhar em grupo - a gente às vezes trabalha na mesma escola e nem se encontra; fica cada um na sua sala";

- " "nunca tinha pensado em trabalhar fora da sala de aula"; 
Um aspecto realçado durante nossa discussão de avaliação foi o prazer obtido tanto com o processo como com o produto do trabalho. Quase todos concordaram que o envolvimento naquelas atividades foi divertido, e que o fato de se divertirem não impediu o aprendizado; muito pelo contrário, tornou-o mais deleitoso.

A partir dessa conversa algumas possibilidades de trabalho em sala de aula foram levantadas: estudo de frutas locais, de plantas medicinais, caminhada em grupo pelos caminhos que os alunos fazem, cada um, de casa até a escola, maquetes de alguma área próxima.

Abaixo, depoimento de Natacilda Barros, estagiária local, feito no encerramento da oficina.

"Foi uma experiência única. Mudamos nossa visão de espaço, passamos a valorizar o espaço, os pequenos espaços. Fomos para uma praça, fizemos uma observação e pudemos entender como é a relação entre a planta e o objeto construído. Desenvolvemos uma visão arquitetônica. Isso faz diferença, pois agora vamos olhar para nossas escolas de outro modo - valorizando mesmo os pequenos espaços".

A linguagem desse depoimento foi certamente utilizada por eu ser arquiteta, mas de qualquer forma, Natacilda fala da questão salientada acima: a importância do estimulo à percepção para a construção do conhecimento.

\section{Algumas considerações}

O estabelecimento de vínculo entre a pessoa que coordena o trabalho e os participantes é fundamental para o bom andamento das atividades. Isso não significa o estabelecimento de amizade, mas sim de um clima de respeito. É fundamental haver espaço não apenas para as dificuldades, mas também para as descobertas de cada um. Essas condições favorecem a expressão das pessoas que, assim sentem-se mais à vontade, para participar ativamente do processo.

Não se pode avaliar, neste momento, se, e de que forma essa experiência transformará a prática desses professores/as em sala de aula, mas algumas idéias foram explicitadas: 
- a sala de aula não é o único espaço de ensinoaprendizagem;

- o ambiente circundante da escola pode fornecer matéria prima excepcionalmente instigante para esse processo;

- trabalhar, produzir, pode ser prazeroso; e quando o é, tudo fica melhor;

- qualquer um pode desenhar;

- $\quad$ um grupo proporciona diversidade, que é algo desejável;

- a percepção precisa ser estimulada.

Noções mais elaboradas de espaço têm condições de serem apropriadas por leigos, caso se apresente ferramentas adequadas para tal; elas podem tanto ser idéias apresentadas em discussões sobre o espaço vivenciado, como técnicas de representação, entre outras.

Os espaços livres não são normalmente valorizados como espaços de aprendizado, sendo tradicionalmente utilizados pelas escolas como áreas de lazer.

trabalho em grupo favorece, estimula e enriquece a produção.

Fazer perguntas é melhor do que respondê-las; as perguntas estimulam a reflexão, a criatividade e a busca de soluções próprias.

\section{Segunda oficina - junho de 2004}

Esta oficina foi desenvolvida também em Marabá, na mesma escola que a anterior, e havia por volta de 10 pessoas que haviam participado da oficina anterior, em novembro de 2003.

Objetivo: Desenvolver a atenção para possibilidades de se trabalhar a percepção com relação ao lugar onde se vive, dentro e fora sala de aula.

\section{Relatório}

$1^{a}$ dia

O dia se iniciuo com uma apresentação pessoal, cada um mostrando no mapa de onde veio sua familia. Essa atividade foi importante para criar familiaridade entre as participantes da oficina. Falou-se também em miscigenação, mistura de 
culturas, convivência com diferentes, conhecimento da história de cada um, entre outros temas.

Em seguida foi proposto que trouxessem à memória um lugar, uma situação, uma paisagem, significativa de sua infância, ou de seu lugar de origem. Em grupos de três ou quatro descreveram uns para os outros, com a maior riqueza de detalhes possível, o lugar, situação ou paisagem escolhidos.

A partir dessa visualização, fizeram uma colagem (com papel espelho) representando esse lugar, situação ou paisagem. $\bigcirc$ envolvimento das pessoas foi bastante grande e as técnicas de colagem utilizadas bastante variadas, o que fez com que fosse sugerido que, no meio do trabalho, todos dessem uma olhada em todos os trabalhos - havia colagens tridimensionais, picotes, recortes à mão, recortes a partir de um desenho, colagens superpostas, franjas, etc. Essa troca é bastante enriquecedora; as pessoas se ajudam passando informações, soluções umas para as outras.

Em seguida, os grupos se reuniram novamente e criaram, a partir dos trabalhos individuais, reconstruindo-os, uma paisagem do grupo. Esse exercício propunha o seguinte: somos únicos, cada um com uma história, e agora nos encontramos - o que podemos fazer com isso?

Cada grupo optou por apresentar seu trabalho relatando como o trabalho individual contribuiu para o coletivo. Foi muito emocionante porque os lugares, situações, paisagens trabalhados eram realmente significativos na história de vida de cada um; e o exercício de contar para os parceiros sua história particular auxiliou muito na recuperação das imagens; alguns relataram que ao descrever uma imagem para o colega ela se tornou mais vívida, mais clara.

À tarde, a proposta era que escolhessem e recolhessem folhas diferentes no jardim da escola para fazer desenhos de observação em papel sulfite, com lápis preto.

A concentração do pessoal nesse trabalho foi muito grande. Informações eram trocadas o tempo todo - "olha essa folha!", "olha como muda quando a 
gente muda a posição dela!", "olha como uma ponta é mais comprida que a outra!". No meio do trabalho foram distribuídas lupas para que passassem a observar e desenhar também os detalhes.

O exercício seguinte foi a composição individual, com lápis preto, de um jardim, num papel vegetal (A4 ou A3, a escolher), copiando ("colando") dos desenhos de observação e de cópias xerográficas de fotos de plantas. Todos desenhos de observação foram recolhidos e redistribuídos de forma a que não necessariamente copiassem de seu próprio desenho. Uma vez terminados os desenhos a lápis preto, coloriram os jardins com lápis de cor. Novamente a concentração no trabalho foi intensa. Como não terminamos os trabalhos nesse dia, combinamos que no dia seguinte quem fosse chegando iria terminá-los.

$$
2^{a} \text { dia }
$$

Assim aconteceu, e foi preciso interromper para que pudéssemos passar para a seguinte: a apreciação dos trabalhos e a conversa sobre a atividade. Perceberam o quanto, muitas vezes, não prestamos atenção às coisas à nossa volta: "vi coisas que nunca tinha visto", "as folhas são como as veias do nosso corpo!", "nunca tinha reparado como as folhas são diferentes".

Uma questão intrigante despertada na oficina anterior: como trazer para dentro da sala de aula o que está fora. A proposta de trabalho para a tarde foi introduzida com perguntas sobre como as crianças e jovens iam para a escola. As respostas foram: de pau de arara, caminhão, moto, canoa, bicicleta, a pé.

"Pessoal, o que esse trabalho que fizemos tem a ver com isso?" Imediatamente disseram que em seus trajetos diários seus alunos passam por inúmeras situações e ambientes (rios, bichos, plantas, vilas, pessoas) que podem ser debatidos e estudados em sala de aula.

Ao final da tarde todos os grupos quiseram apresentar seus trabalhos da última atividade, que não será relatada aqui, e foi feita a avaliação da oficina. A falta de foco e o excesso de solicitações forçaram a alteração do planejamento que, neste caso, acabou resultando numa atividade muito confusa e dispersa, que não 
atendeu aos objetivos iniciais, apesar de as pessoas terem se envolvido bastante nela.

\section{Algumas considerações}

É fundamental a explicitação das razões do uso da linguagem artística em processos dessa natureza, para que as pessoas não se sintam inibidas para algum exercício.

As pessoas:

- demonstram uma percepção maior dos detalhes de seu ambiente quando os representam graficamente;

- desenvolvem a consciência visual do seu ambiente observando seus detalhes;

- $\quad$ têm maior possibilidade de interpretação de seu meio quando observam-no com atenção.

O final dos trabalhos foi muito corrido; é indispensável garantir um tempo confortável para sua discussão e avaliação das práticas.

A avaliação de qualquer trabalho participativo deve ser também participativa, ou seja, as críticas, os comentários, as sugestões, devem ser discutidos com todos os envolvidos, para que haja apropriação dessas idéias por todos.

\section{Oficina São Paulo 450 Anos}

Estas oficinas foram promovidas pela prefeitura da cidade como forma de sensibilizar professores da rede pública municipal para a utilização de um kit editado nessa ocasião, que conta a história de São Paulo e de suas escolas públicas, e que foi distribuído para todas as escolas. $\bigcirc$ kit consiste de dois livros e uma série de pranchas com imagens, em sua maioria antigas, da cidade de São Paulo ${ }^{26}$. Participei como 'oficineira' do CEDAC.

${ }^{26}$ KOK, Gloria - "São Paulo 450 Anos: De Vila a Metrópole", São Paulo: Bei Comunicação, 2004. CRUZ, José Armênio de Brito; CARVALHO, Lúcia - "São Paulo 450 Anos: A Escola e a Cidade", São Paulo: Bei Comunicação, 2004 
Objetivos: Despertar/desenvolver o interesse pela história da cidade

- $\quad$ Fazer com que cada um atente para sua inserção na história da cidade (ler "SP 450 Anos Luz"27 capítulo 2, pg.42)

- Despertarldesenvolver o interesse pela história das edificações escolares públicas da cidade

- Despertarldesenvolver a percepção para o ambiente em que se vive, no caso, a cidade de São Paulo

- Conversar sobre possibilidades de trabalho com o kit

- Trabalhar o sentido de pertencimento, para que as pessoas possam se tornar mais atuantes como cidadãs

Relatório

$I^{a}$ manhã

O imprevisto surgiu logo no início das atividades; como poucos chegaram no horário, reunimos pessoas de três oficinas numa só. A primeira atividade foi a apresentação de cada um, mostrando num mapa do Brasil, e outro do Estado de São Paulo, o lugar de origem de sua familia e, no mapa do município, o lugar onde morava. Como este último mapa era do centro expandido, muitos não puderam se localizar ali, e reclamaram disso. Aos poucos chegaram outras pessoas, então dividimos o grupo em dois, cada um com 15 pessoas.

Foi proposto, que ao som de música clássica, de olhos fechados, procurassem se concentrar, por dez minutos, numa situação, lugar, paisagem que tivesse tido importância na infância de cada um. Em seguida, reuniram-se em grupos para relatar uns aos outros as imagens que thes vieram à mente e depois fizeram, individualmente, uma representação dessa imagem usando lápis de cera e lápis de cor. Os trabalhos foram postos na parede e cada um apresentou o seu ao grupo todo.

27 SOUZA, Okky de, e DIMENSTEIN, Gilberto, "São Paulo 450 Anos Luz", São Paulo: Editora de Cultura/Comgás, 2004. 
O exercício foi muito intenso e envolvente e detonou uma conversa sobre qualidades positivas e negativas de espaços para atividades de crianças e jovens. Essa conversa foi baseada fundamentalmente na vivência de cada um, nas experiências de cada um na infância e juventude. Foram citados como locais 'gostosos' aqueles que são: amplos, bem iluminados, aconchegantes, coloridos, próximos da água (lago, rio, piscina), vegetados, freqüentados por pessoas queridas (familiares e/ou amigos), grandes.

\section{$1^{a}$ tarde}

O livro sobre a história de São Paulo foi apresentado, juntamente com as pranchas de imagens da cidade, e também algumas imagens de paisagens variadas (abaixo algumas delas), como forma de estimular uma discussão sobre a paisagem de São Paulo - a real e a que se deseja.

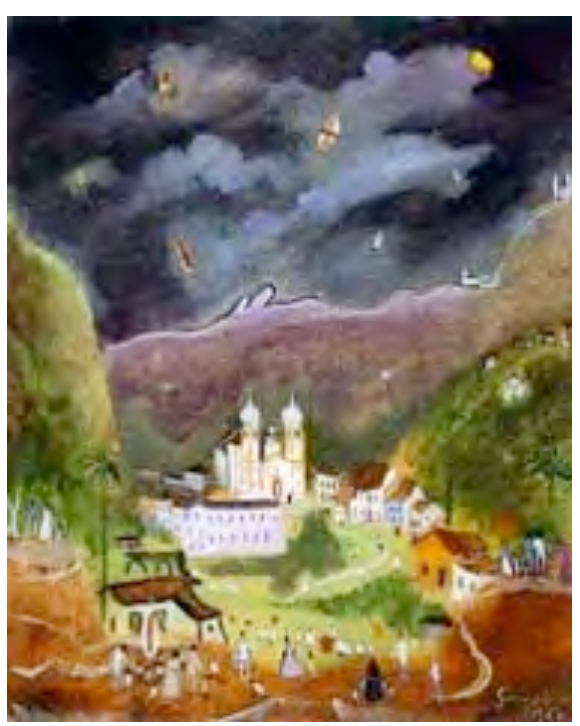

Alberto da Veiga Guignard Festa de São João - Ouro Preto

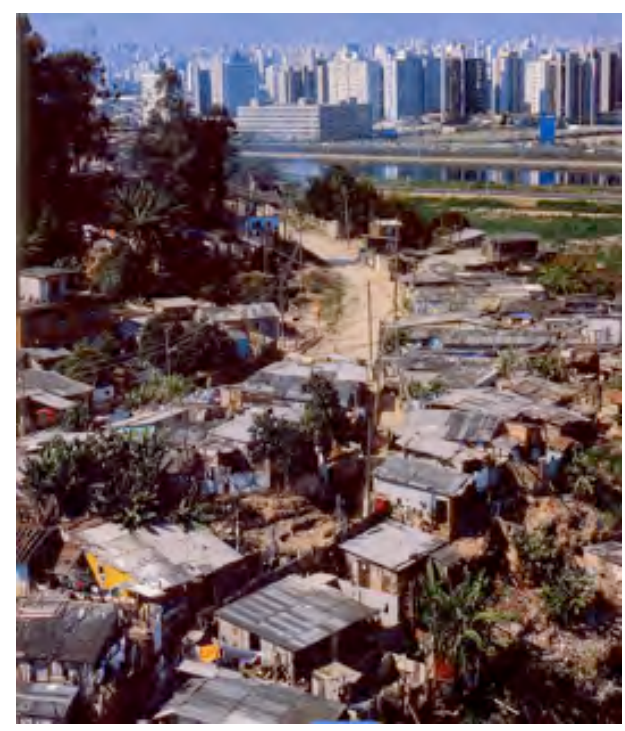

São Paulo 


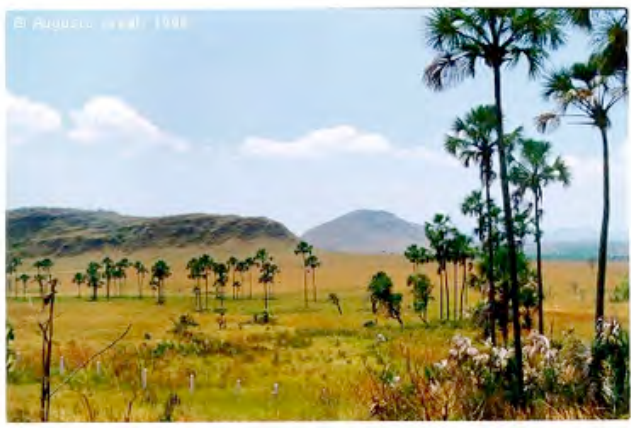

Chapada dos Veadeiros

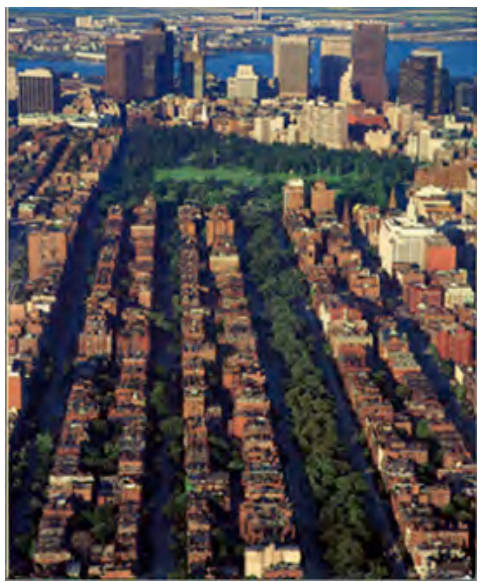

Foto aérea de uma

cidade Americano

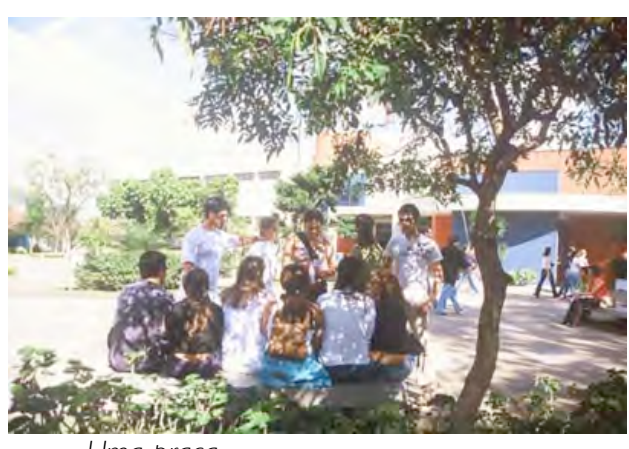

Uma praça

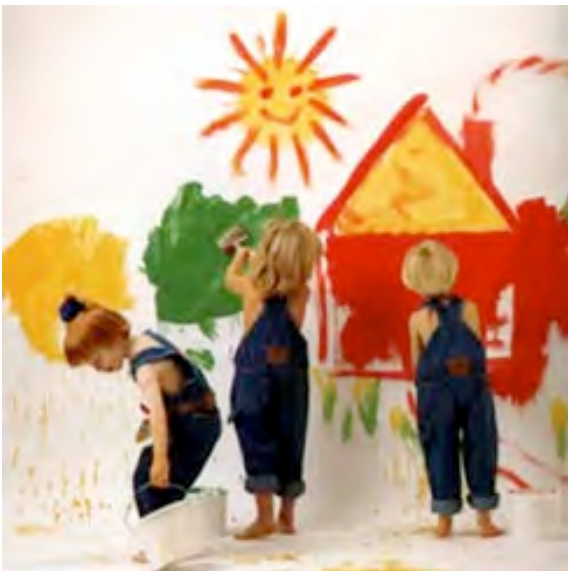

E a nossa paisagem? Como ela é? Como gostaríamos que ela fosse?
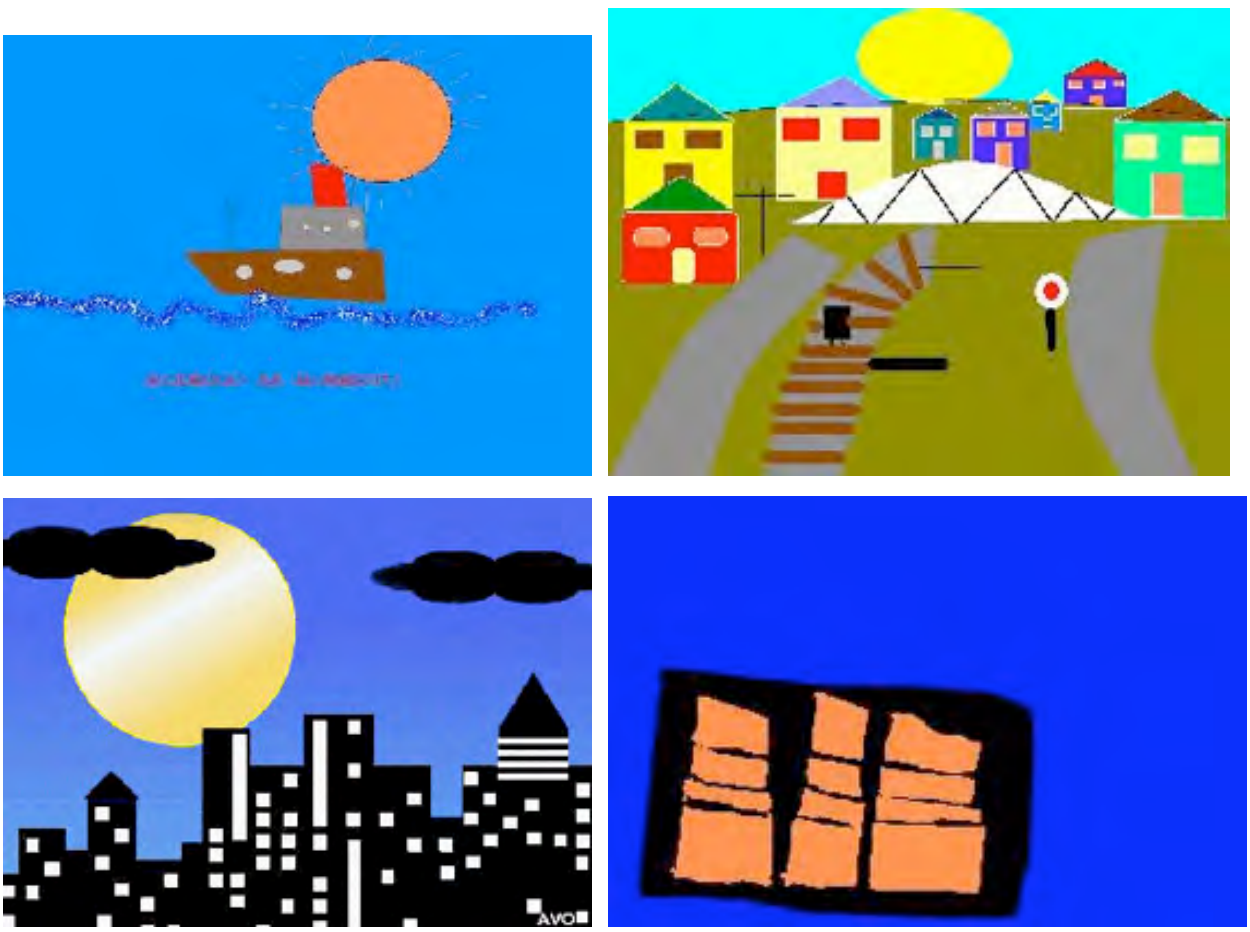

4 Releituras de Tarsila do Amaral feitas por crianças 
A discussão foi bastante proveitosa e surgiram várias idéias sobre possibilidades de trabalho com seus respectivos alunos, em função da observação da cidade real, da cidade onde eles vivem. Levantou-se questões como a necessidade de sonhar - algumas imagens mostravam paisagens inventadas -, a importância da observação, a necessidade de se utilizar linguagens diversas, com os alunos, para enriquecer seus trabalhos e suas discussões.

Também foi debatido o desconhecimento da história e das paisagens de São Paulo, por parte de muitos de seus habitantes, e como isso faz falta para que os professores possam atuar de forma adequada quando dão aula.

\section{$2^{a}$ manhã}

I. Conversa sobre espaços escolares da vida de cada um:

- lugares preferidos: sala de leitura ("porque minha mãe arrumou, fez as almofadas"), pátio "escondido", grande, variedade, quadra, arborização, cor, laboratório, pátio, pátio enorme, boa manutenção, espaços amplos, "cantinho", área externa (pasto, vacas), pé de manga, corredores escondidos;

- Iugares preteridos: banheiros, sala da diretoria (pequena), má manutenção, quadra, salas pequenas

2. Apresentação do livro das escolas

3. Exercício do olhar acompanhando as linhas do espaço que se vê com o dedo (o mesmo da oficina de Marabá)

4. Desenho de observação (com lápis preto) de algum lugar da escola onde estávamos trabalhando. Cada pessoa, depois de andar um pouco pela escola (elas não eram professoras lá), escolheu um lugar para desenhar. Os desenhos suscitaram um debate sobre o porque das escolhas, o que cada uma representava para cada professora, e partir disso conversamos, novamente, sobre as qualidades de cada lugar. A técnica do desenho como exercício de observação também foi discutida; muitos se surpreenderam com a quantidade e a qualidade das informações e idéias despertadas a partir dessa atividade. 
5. A partir dessa conversa, foram levantadas possibilidades de trabalho com os alunos dos professores ali presentes, tendo como referência os livros e pranchas, e as atividades feitas durante a oficina; disso resultou num cardápio de opções:

- desenhar percurso casa-escola;

- fazer maquete da escola;

- fazer estudo do meio no bairro com o objetivo de melhor conhecê-lo; o resultado pode ser uma maquete;

- fazer pesquisa da vegetação existente no ambiente do aluno e um álbum de ilustrações;

- fazer entrevistas, uns com os outros e em seguida um retrato uns dos outros (em duplas).

6. Avaliações finais - "Como você vê São Paulo depois da oficina?":

- $\quad$ "Mil vezes maior e vista de uma maneira mais otimista com muito mais possibilidades de melhorar."

- "O mesmo que eu pensava."

- " "Ficou mais conhecida."

- " "Por enquanto nada."

- "A cidade ficou mais próxima de meus sentimentos depois de conhecê-la mais como era no passado."

- "Ampliou a visão da cidade com relação à história e sua formação."

- "Cidade 'idealizável'."

- Já tinha um carinho muito grande por SP, e agora um pouco mais."

- "Minha história está inserida em São Paulo, a partir da leitura artística."

- "Cidade de mil olhares."

- "Consigo ver a beleza no caos."

- "Sensação de saudosismo: ela já era grande sem ser depredada."

As atividades foram encerradas com a leitura de uma história de tradição oral "Uma Alegoria ou um Conto de Fadas?", do livro "Community Culture and the 
Environment" ${ }^{\prime 28}$ Essa história (Anexo V) fala da importância das inúmeras e distintas visões possíveis de situações que se apresentam em nossas vidas e de como cada ponto de vista contribui para a construção de um conhecimento comum. $\bigcirc$ dia foi finalizado com o debate em torno dessa história.

\section{Algumas considerações}

É preciso haver flexibilidade nas propostas de processos que contam com a participação ativa de todos os envolvidos; o plano é apenas uma orientação e não a garantia do que vai acontecer durante o processo.

É muito importante que os participantes sejam inseridos no processo e isso se dá de forma muito viva quando suas experiências, suas vivências são valorizadas.

Novamente podemos observar que o desenho é uma linguagem que estimula a observação, a percepção. A cidade e seus espaços livres são um tema muito rico para trabalhos com jovens e crianças.

\section{EXPERIÊNCIAS NO CANADÁ}

Conforme dito na Introdução deste trabalho, durante o período do mestrado, em 2005, fui intercambista do Programa Bacias Irmãs, tendo estudado por um semestre na Escola de Estudos Ambientais da Universidade York, em Toronto, Canadá. Algumas atividades das quais participei em minha estadia naquela cidade enriqueceram muito minha visão não apenas de possibilidades de participação popular no espaço público, mas também do caráter desse espaço.

Canadá é um país jovem, rico, com uma densidade populacional muito baixa. ${ }^{29}$ Sua sociedade tem uma cultura bastante distinta da brasileira: lá o Estado é presente no espaço público, a população sabe quanto a cidade investe em cada

28 US EPA, Office of Water - "Community Culture and the Environment: A Guide to Understanding a Sense of Place". Washington, DC: 2002.

${ }^{29}$ Canadá - População: 32.907 .000 hab/Área: 9.984 .670 km²/Densidade: 3,2 hab./km² Brasil - População: |88.181.069/Área: 8.514 .877 km²/Densidade: 22 hab./km² 
empreendimento e cobra do Estado a aplicação de recursos de acordo com suas necessidades; acompanha-se alterações eventuais de horários dos ônibus, gastos com projetos de parques, entre tantas outras coisas. Existe no país uma cultura de participação consolidada; os espaços públicos são utilizados pela população sempre em parceria com a prefeitura (feiras, teatro, espetáculos de dança, etc.); e, finalmente, o sistema educacional é satisfatório. Existem problemas, é claro, mas a estrutura básica é bastante sólida. No Brasil o sistema público educacional passa por séria crise; a maior parte dos espaços públicos são abandonados ou irregularmente apropriados; não se tem uma cultura estabelecida de participação; a população sabe que os recursos são utilizados de forma irregular e de maneira que não atende às suas necessidades.

Uma característica marcante dos espaços públicos de Toronto é a a presença maciça de crianças. Pelo fato de não haver com quem deixar crianças em casa, elas participam de tudo - vão às oficinas, às atividades de discussão de atividades em parques, e assim por diante. Elas naturalmente fazem parte dos grupos que participam de trabalhos ou atividades participativas e, por isso, muito frequentemente se organizam atividades especialmente para elas.

Apesar da cultura diferente, e talvez até por causa disso, toda a série de atividades aqui relatas, observadas em espaços públicos de Toronto, que envolvem a participação da comunidade, permitem-nos fazer algumas reflexões.; mesmo sendo, algumas delas, apenas experiências de uso do espaço público, e não de leitura ou intervenção na paisagem.

Os projetos e/ou atividades descritas e comentadas a seguir forneceram subsídios para reflexão sobre projetos participativos no Brasil, pelo seu caráter de viabilidade. Será certamente necessário fazer um rebatimento das questões observadas nesses projetos, mas também é certo que tais questões são pertinentes também à nossa realidade. 


\section{BRING BACK THE DON ${ }^{30}$}

Bring Back the Don é uma organização não governamental que luta pela melhora da qualidade ambiental do Rio Don; este rio atravessa a cidade de Toronto e deságua no Lago Ontário. Num sábado de manhã foi promovido o que se chamou de 'oficina'. O encontro foi num antigo moinho - Todmorden Mills onde hoje funciona uma galeria de arte, e compareceram por volta de 30 pessoas. Havia 3 'estações' por onde todos deveriam passar, em grupos, alternadamente:

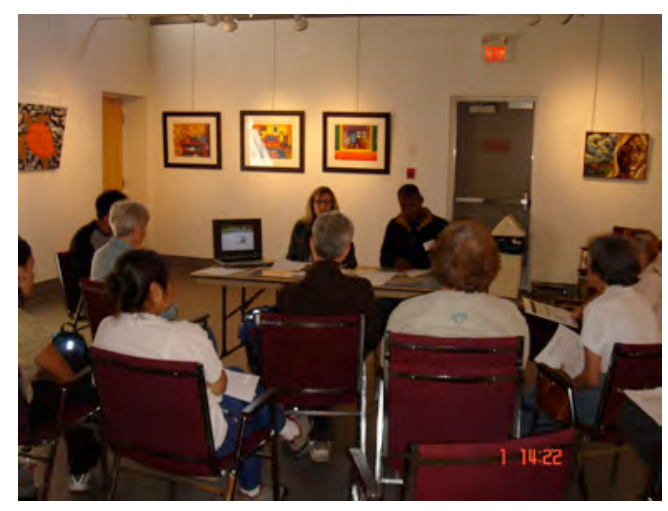

Estação I: A dinâmica da água numa bacia hidrográfica

Dois voluntários explicavam, com a ajuda de uma apresentação no Power Point, como a água se comporta de acordo com o solo e o relevo.

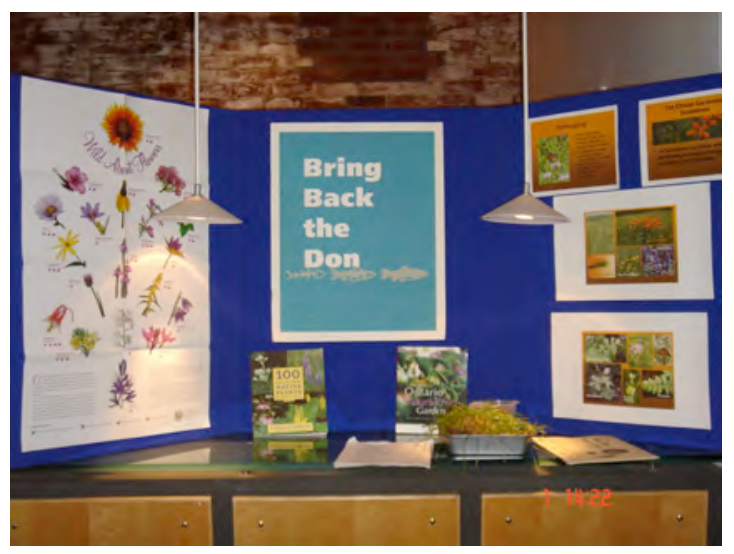

Estação 2: Vegetação nativa e adubos orgânicos

30 "Trazer de Volta o Don" 
Uma voluntária explicava a importância do uso de vegetação nativa e de adubos orgânicos nos jardins das casas para melhorar a qualidade do ambiente e evitar poluição;

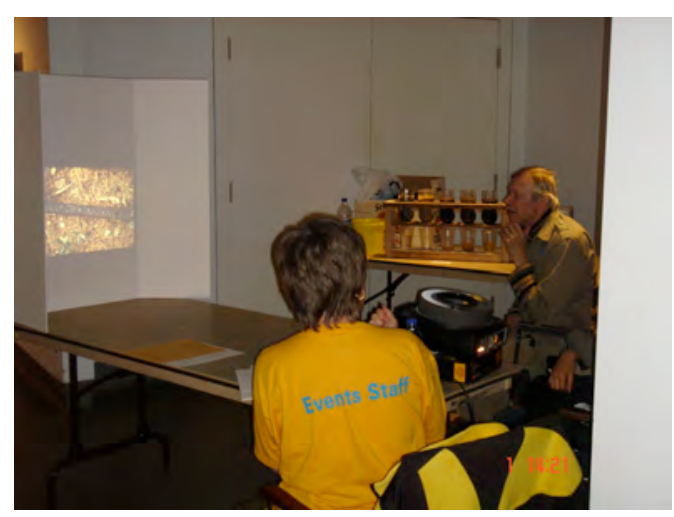

Estação 3: Permeabilidade dos jardins

Outra ainda apresentava a importância da não pavimentação das áreas na frente das casas para que a água possa infiltrar no solo e não escoar pela superficie causando problemas de poluição de rios e de enchentes; ela dava informações também sobre os vários tipos de solo e suas características de permeabilidade.

Pouquíssimas pessoas compareceram ao evento, mas para os organizadores o número de pessoas foi satisfatório. Na verdade não houve verdadeira participação ativa da população, e sim uma atividade informativa a respeito de questões ambientais diretamente relacionadas com o rio e sobre as quais os moradores da cidade podem ter alguma atuação. 


\section{Algumas considerações}

Em cada uma das 'estações' era dada uma aula sobre um assunto. Os temas abordados são essenciais para a cidade e seus habitantes. Em Toronto, onde quase todo mundo tem um pequeno jardim, é necessário que as pessoas saibam da importância da permeabilidade do solo e da utilização de plantas nativas, pois cuidar do jardim faz parte do dia-a-dia delas e assim cada um faz a sua parte; é primordial também que elas compreendam o porque disso, compreendendo a dinâmica das águas na cidade.

As atividades em questão não poderiam ser chamadas de oficina, visto que as pessoas que compareceram e tiveram uma atuação passiva. Durante as atividades foram feitas perguntas, e estas foram respondidas a contento. As pessoas passaram por apresentações que Ihes forneceram informações úteis para a sua prática de jardinagem; e elas saíram satisfeitas. Para os organizadores, os objetivos foram alcançados.

\section{LOST RIVERS WALK 31}

Lost Rivers é uma organização que tem como objetivo "encorajar o entendimento da cidade como parte da natureza ao invés de algo separado dela, e apreciar e tratar com carinho nossa herança [a herança natural de Toronto]. Criar uma apreciação da íntima conexão da cidade com seus sistemas hídricos, traçando os cursos de riachos esquecidos, aprendendo sobre nossa herança natural e cultural; e compartilhando essas informações com outros." ${ }^{22}$

No dia 2 de outubro de 2005 foi organizada uma caminhada ao longo do Garrison Creek, córrego que hoje é canalizado e subterrâneo. Mais de cento e cinqüenta pessoas compareceram, incluindo por volta de vinte crianças. A proposta

\footnotetext{
31 "Caminhada pelos Rios Perdidos"

32 Do site www.lostrivers.ca
} 
era a conscientização das pessoas a respeito da existência do córrego, ainda que escondido, e a recuperação de sua história. Abaixo, algumas fotos do evento.

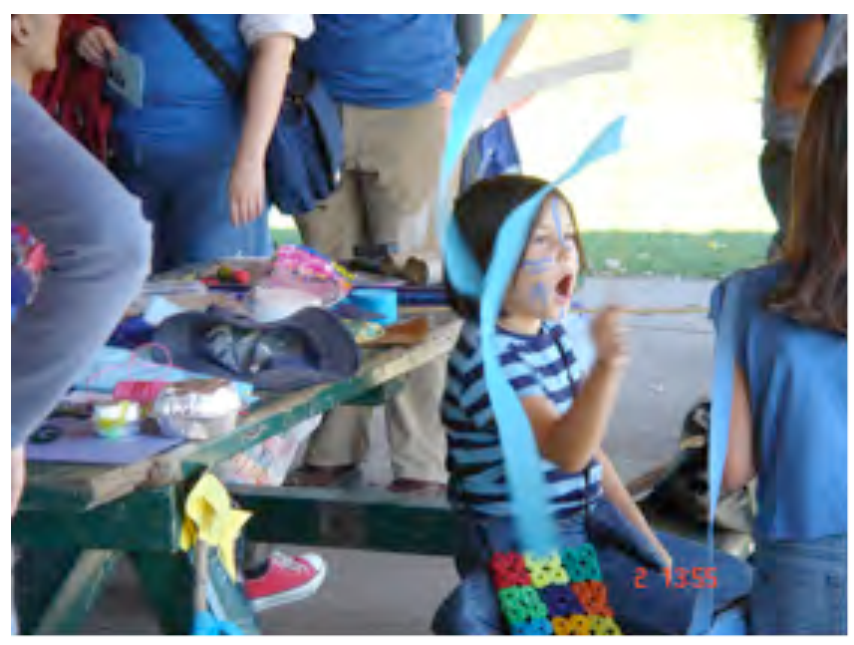

O encontro do grupo foi num parque - Christie Pits - e se iniciou com uma oficina de arte para as crianças, e também adultos, prepararem bandeirolas, peixes, chocalhos, ou o que mais quisessem para carregar durante a caminhada. Havia também material para pintura facial e de cabelo. A proposta era que as pessoas estivessem vestidas e pintadas de azul para formarem a representação de um 'rio humano'. Havia uma pessoa com um megafone contando algumas histórias sobre o rio e dando coordenadas para a caminhada. Depois de um tempo 'fazendo arte' saímos em grupo caminhando, fazendo o percurso do rio. Passamos por um parque onde havia, no chão, um mapa da área com o seu traçado.

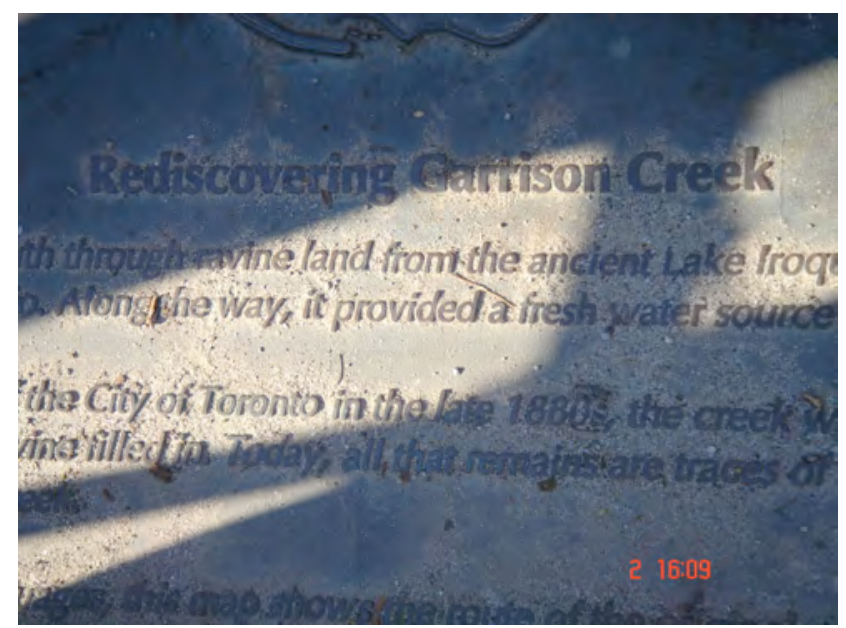




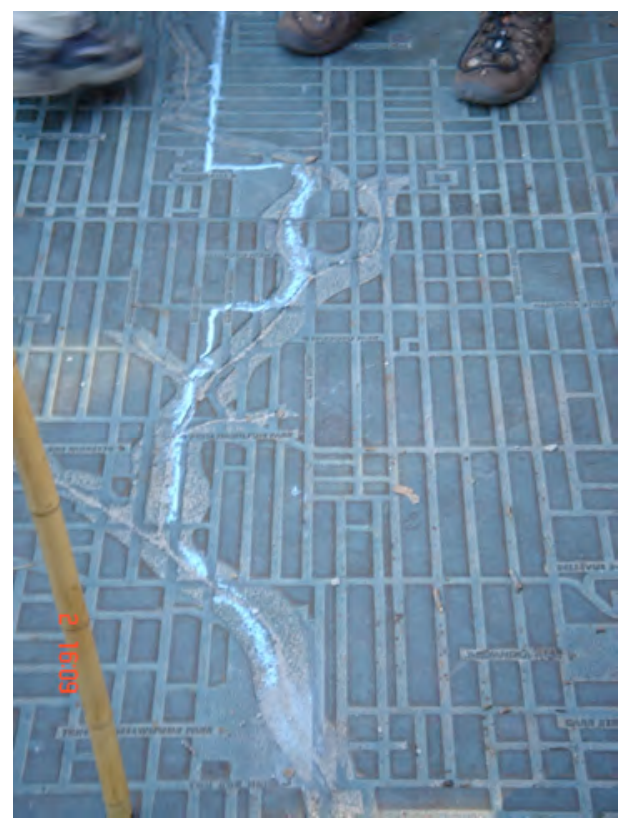

Placa de ferro na calçada, com o mapa da região e o percurso do Garrison Creek.
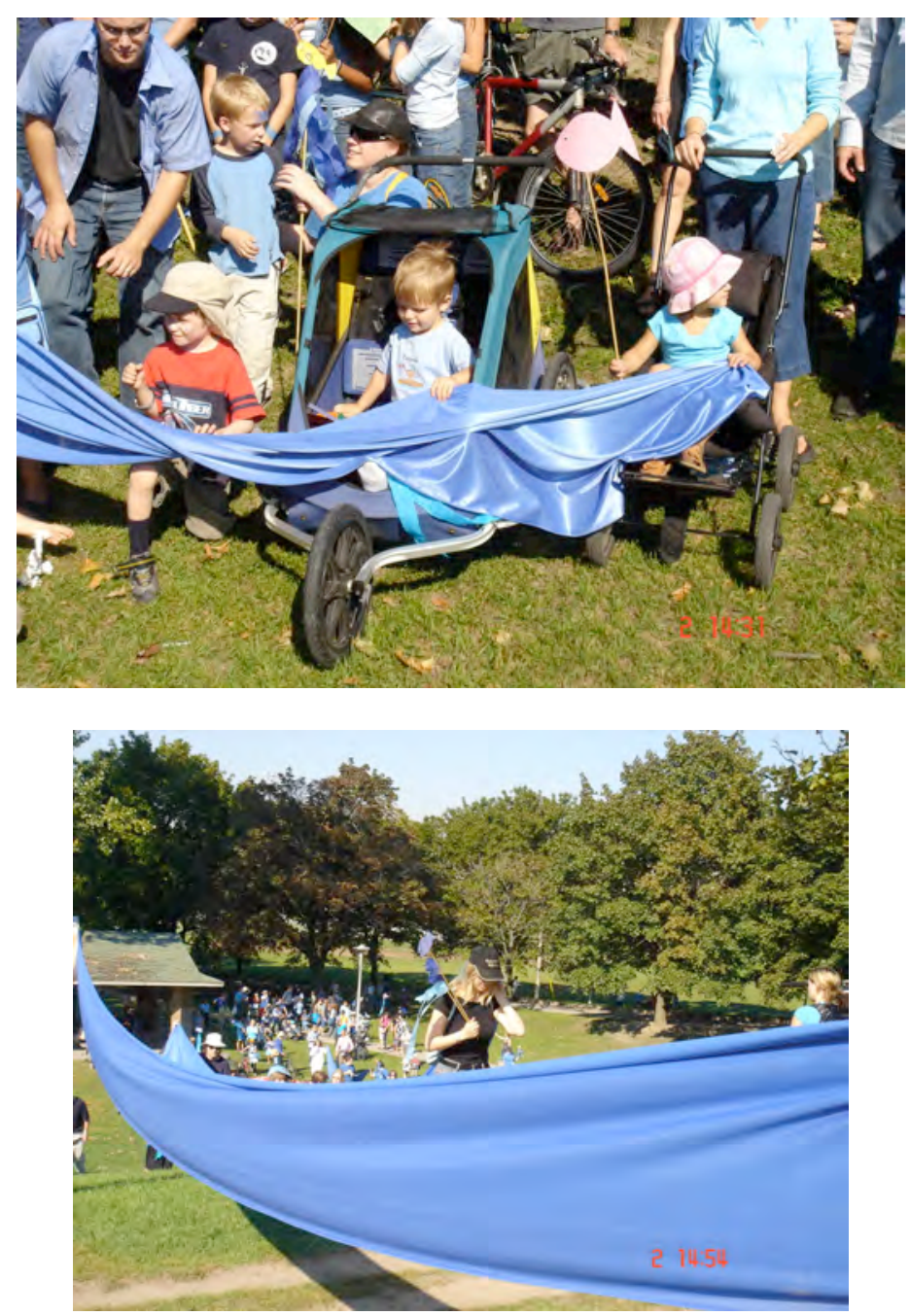

Paisagem como encantamento: experiências $\diamond 119$ 
O número de participantes foi pequeno se tomarmos como referência eventos públicos na cidade de São Paulo.

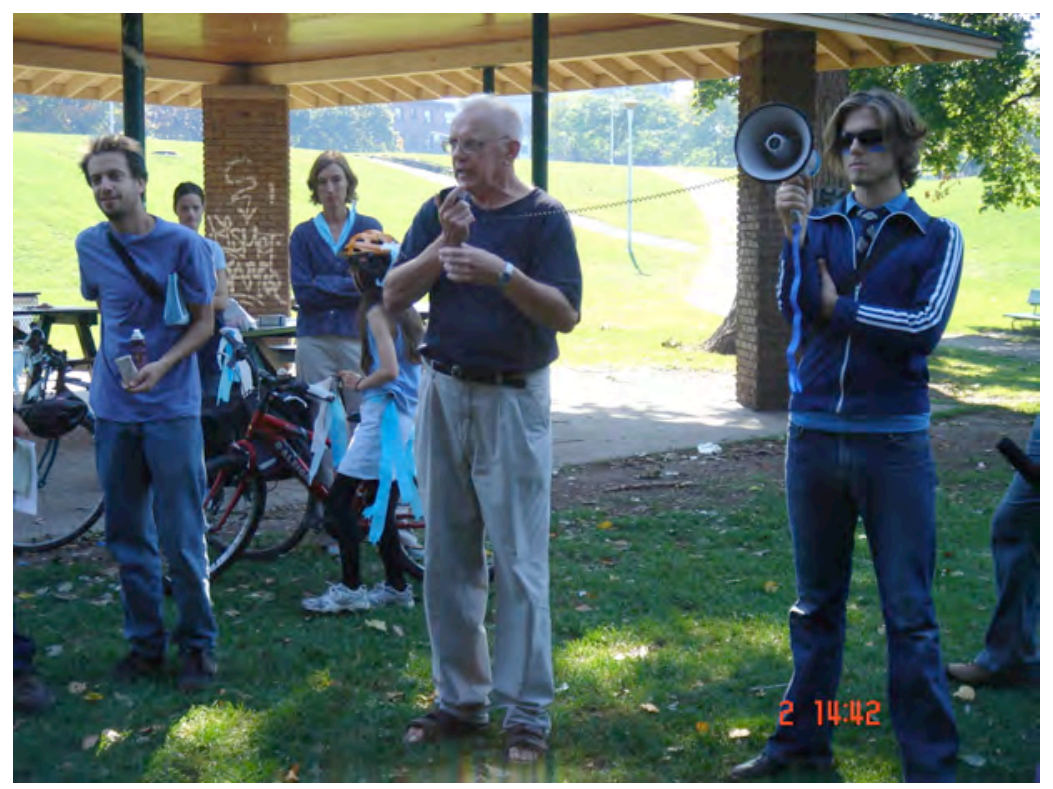

Alguns dos organizadores do evento. (Mez, à esquerda)

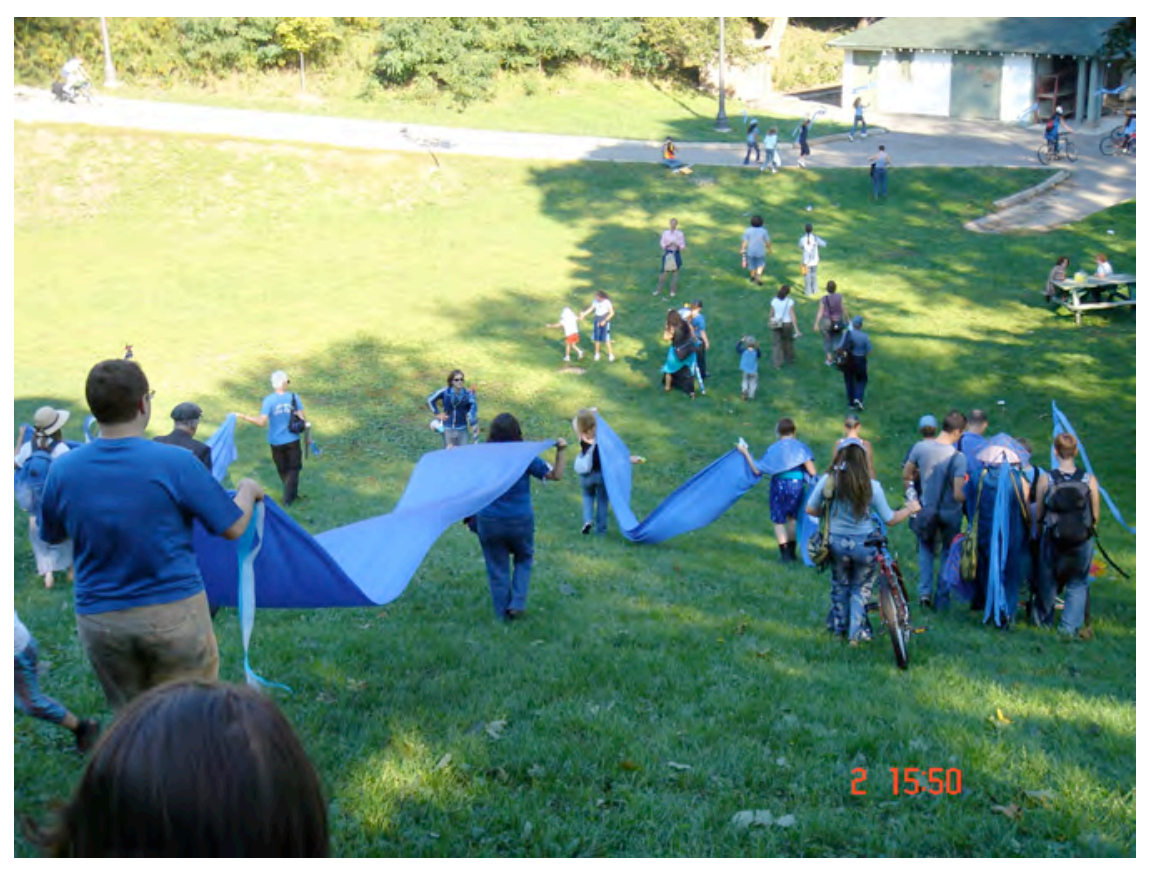


Fizemos uma entrevista com David Mezlin (Mez), coordenador do evento em 2005, para compreender melhor a proposta do grupo que a organizou.

1. Qual era o principal objetivo das organizações que promoveram o Human River Walk ao longo do Córrego Garrison?

R: Dois objetivos principais. Ajudar a criar consciência e celebrar nosso ambiente natural, incluindo as partes que foram escondidas ou 'perdidas'. E também, criar comunidade, reunindo pessoas para uma experiência participativa compartilhada.

2. Você considera I50 um número considerável de pessoas, se pensar em seu objetivo principal?

R: Ficamos satisfeitos com os números. Talvez possamos crescer nos próximos anos. Mas nossos recursos eram limitados e não poderíamos lidar com mais gente! Penso que 1.000 pessoas andando sobre o rio seria legal.

3. E você considera que o objetivo principal foi atingido?

R: Certamente. Nosso objetivo teria sido alcançado com 30 pessoas. Tivemos um grupo grande com ampla gama de idades, muito ativo, ouvindo o que se dizia no megafone e se divertindo. Também ampliamos a consciência de todas as pessoas que viram a caminhada e perguntaram do que se tratava. E, é claro, a mídia. Outros milhares de pessoas receberam a mensagem lendo artigos no jornal.

4. Vocês avaliaram o evento? Quais foram as conclusões?

R: Não foi feita uma avaliação formal. Mas conversamos informalmente e concordamos que o evento foi fantástico. Fizemos algumas anotações sobre como melhorar a caminhada do próximo ano, mas sentimos que começamos um evento anual maravilhoso que só vai crescer.

5. Existe alguma maneira de saber se os folhetos que foram distribuídos à população durante a caminhada tiveram algum impacto nas pessoas?

R: Nunca se sabe. Tenho certeza que alguns foram jogados no lixo. Mas tenho a mesma certeza que a maioria deles foi lida, e alguns ainda estão sendo lidos, ou estão 
em estantes nas casas das pessoas. As fotografias (do folheto) foram importantes, porque permitiram às pessoas ver como era aquela paisagem anteriormente. Em particular, as pessoas gostaram de ver as fotos das pontes enterradas.

6. Haverá alguma continuidade dessa caminhada?

R: Neste momento, as pessoas estão planejando a caminhada de 2006! Acredito que ela esteja marcada para o dia 4 de junho. Há outros grupos que se encontram para falar de planos para descanalizar o córrego ou plantar mais árvores na área. Nosso grupo é focado na criação do evento da caminhada e na ampliação da consciência através da participação.

7. Os websites thes dão alguma informação sobre o que pensam ou fazem as pessoas a respeito da questão que vocês estão colocando para discussão?

R: Acho que não. Também não tenho certeza se estamos colocando alguma questão! É realmente apenas uma celebração com um pequeno componente educacional. O que as pessoas farão depois, é decisão delas!

8. Existe alguma outra forma de vocês terem essa informação?

R: Podemos nos conectar a outros grupos, e listar encontros de grupos em nosso website.

\section{Algumas considerações}

Podemos observar que os objetivos eram pouco ambiciosos, mas muito claros e simples:

- " "ajudar a criar consciência e celebrar nosso ambiente natural, incluindo as partes que foram escondidas ou 'perdidas';

- e também, criar comunidade, reunindo pessoas para uma experiência participativa compartilhada."

Eles foram alcançados. Muitas vezes nos propomos a algo tão abrangente que fica impossível dar conta de sua execução ou do alcance de seus objetivos. A 
clareza e simplicidade de metas a serem alcançadas foi primordial para o êxito dessa atividade.

Aqui pudemos observar novamente a idéia do prazer na participação em grupo e a importância da sensação de pertencimento a um grupo e a um lugar. Todos estavam se divertindo.

A linguagem artística também foi utilizada nesta atividade; a oficina de produção de elementos a serem vestidos ou carregados durante a caminhada teve um papel fundamental na configuração do grupo, pois ela foi o momento em que pessoas, que estavam se conhecendo naquela situação, puderam interagir e iniciar uma conversa sobre o motivo que as levou até lá: fazer o percurso de um córrego escondido, ou 'perdido', como dizia o nome do evento. Nas representações plásticas elaboradas ali surgiram peixes, a cor azul, um 'rio' de tecido azul, ou seja, os elementos 'desaparecidos', escondidos pela canalização do córrego.

\section{DUFFERIN GROVE PARK}

Este parque é bastante central; fica próximo ao metrô e tem acesso fácil, bem como quase toda a cidade de Toronto. Ele é um parque diferenciado porque a comunidade local atua intensamente na sua gestão. Participamos de inúmeras atividades comunitárias ali.

\section{Feira de degustação de alimentos}

Uma feira de alimentos vendidos diretamente pelo produtor (cogumelos, geléias, cidra de maçã, panquecas de champignon, mel, etc.) recebia principalmente familias, que almoçavam por ali. As próprias pessoas que produziam os alimentos estavam nas barraquinhas preparando as comidas e bebidas, explicando a forma de produção, servindo e divulgando seu trabalho. Podia-se comprar amostras dos alimentos, com fichas que eram adquiridas na 'entrada'. $\bigcirc$ ambiente era de absoluta calma; havia um numero de pessoas adequado ao local e ao que estava sendo oferecido. 

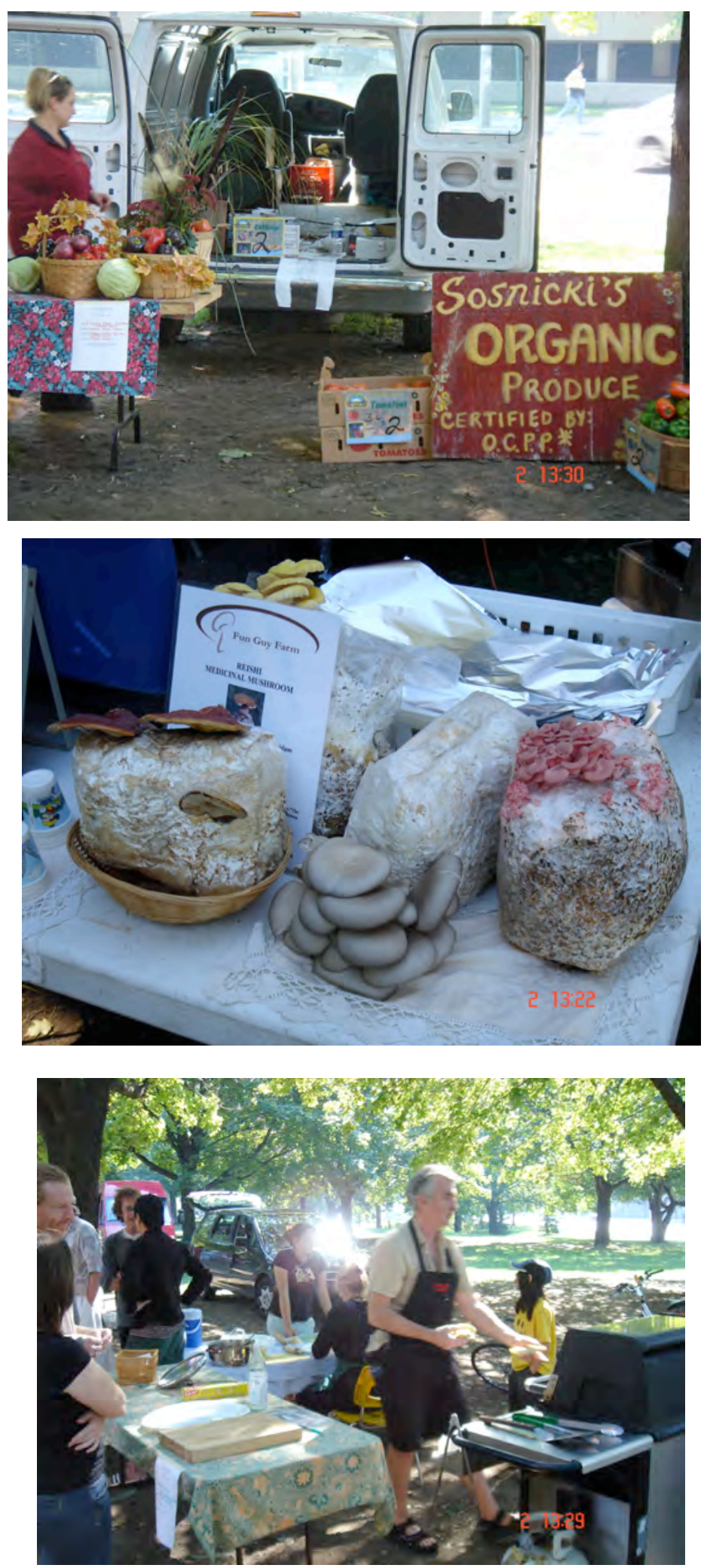


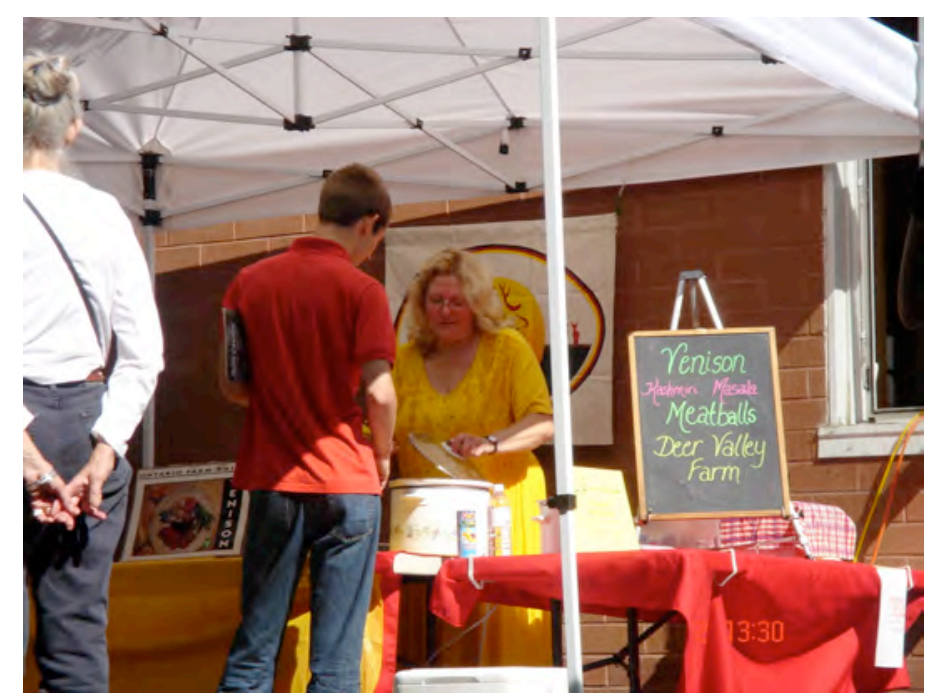

O parque foi parcialmente ocupado por essa feira, de forma que do outro canto dele nem se vê o agrupamento de pessoas ali. Podemos ver como as pessoas se sentem à vontade tanto expondo como comprando as fichas para trocar pela amostra para degustação. $\bigcirc$ parque é delas; a feira é organizada por elas, o espaço se mantém limpo e a convivência é muito pacífica.

\section{Pizza comunitária}

Esta é uma atividade onde cada um leva seu prato, sua bebida, o recheio de sua pizza, e monta a sua própria pizza. Funcionários da prefeitura tomam conta das mesas e do forno, e preparam a massa.

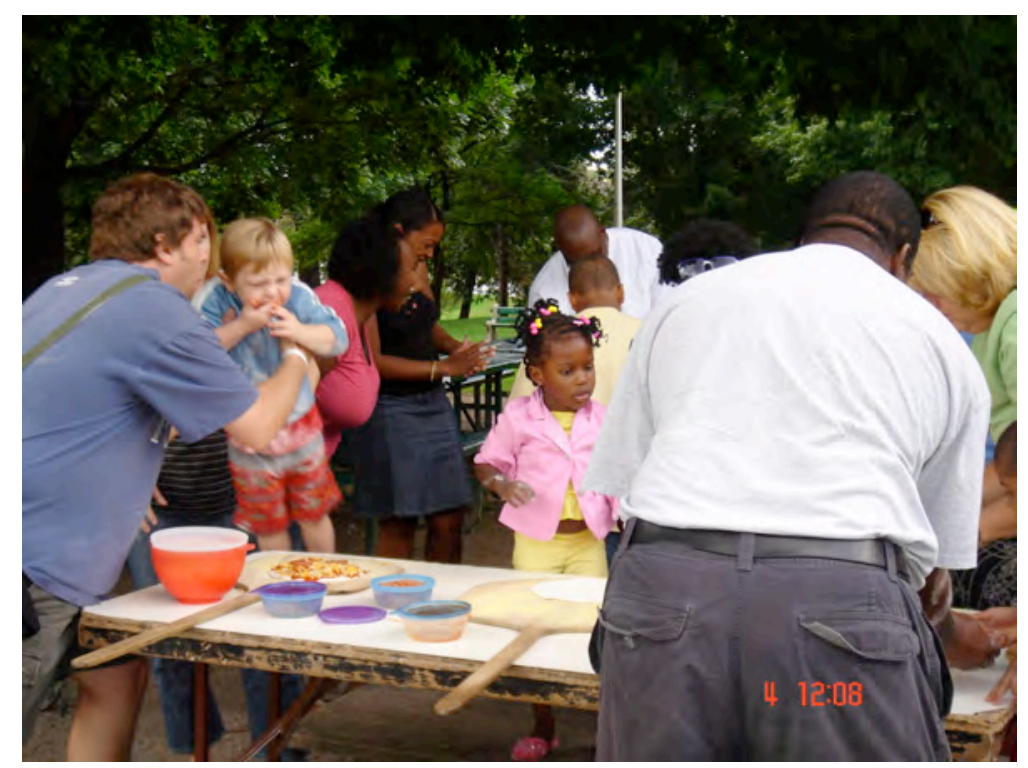




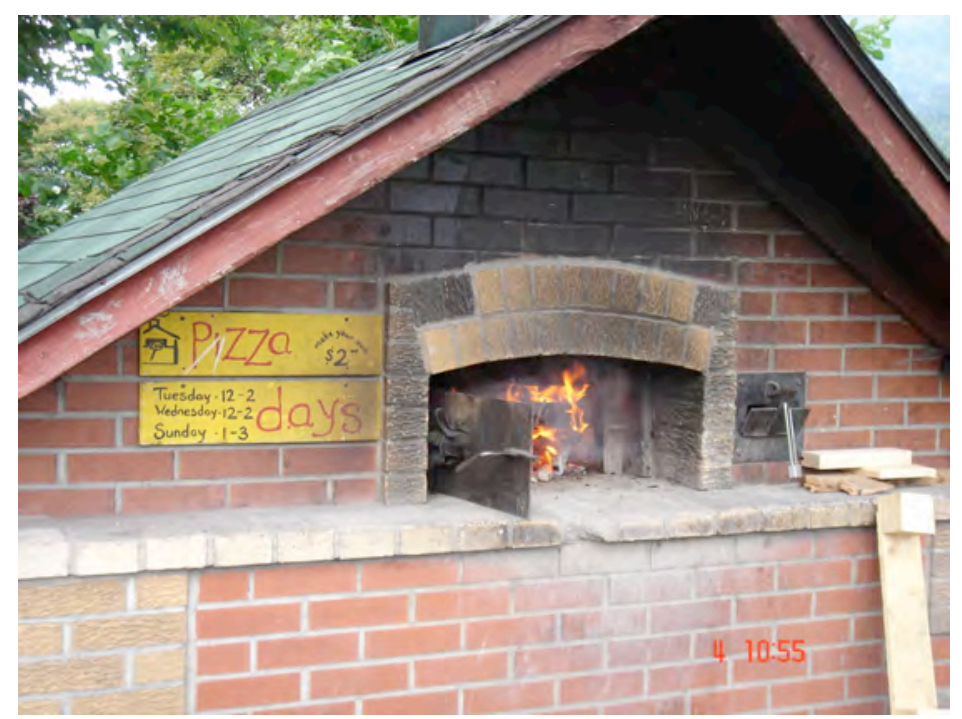

Aqui podia-se notar, novamente, como o pequeno número de pessoas no espaço público (nos dias em que estivemos lá havia por volta de 20 pessoas, incluindo as crianças) favorece um ambiente prazeroso, com as pessoas se divertindo muito ao preparar sua própria pizza.

\section{Construção de adobe para crianças}

Esta construção foi executada sob a orientação de um técnico e pelas mãos de por volta de 500 moradores da área e freqüentadores do parque.

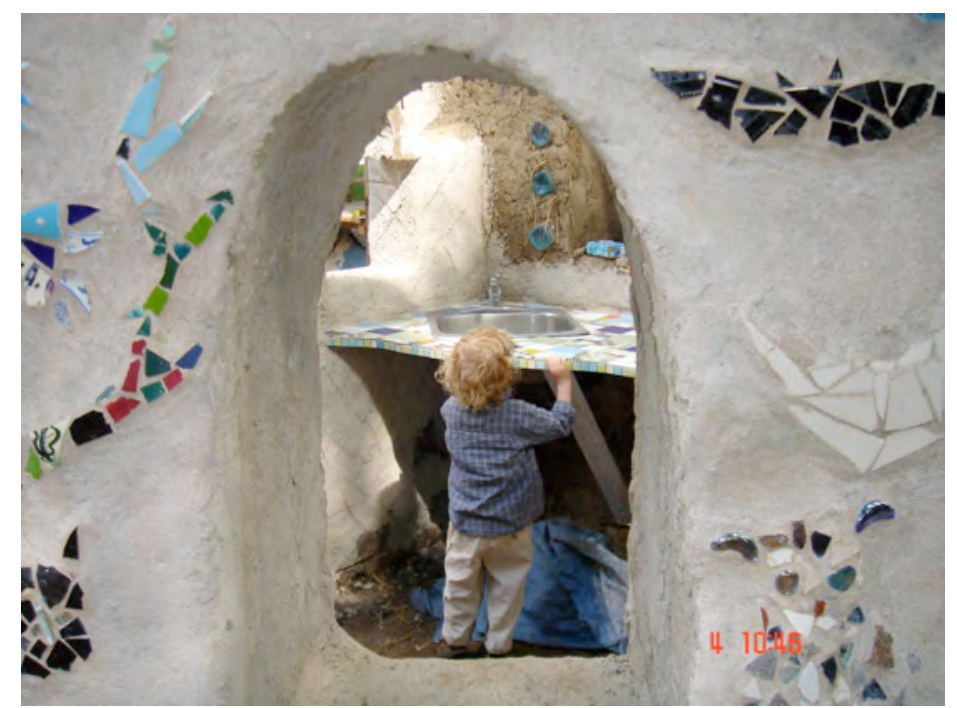



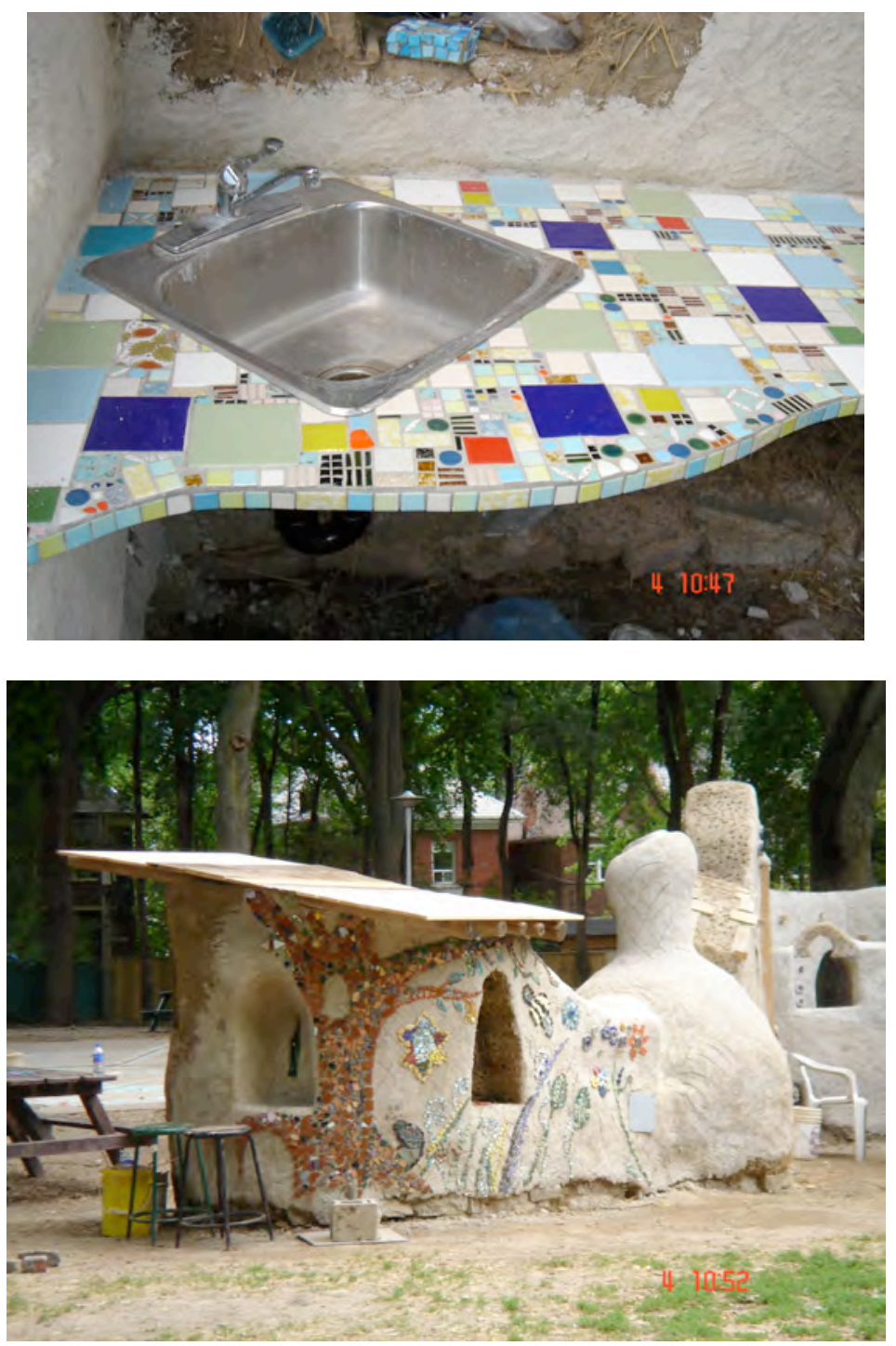

No dia de sua inauguração houve uma festa, com jantar, para umas 300 pessoas. Ela foi preparada pela comunidade em parceria com a prefeitura. Havia sopa para crianças pequenas, comida vegetariana, bebidas não alcoólicas e sobremesas. $\bigcirc$ jantar era pago - algo em torno de 6 dólares canadenses - e quem levasse seu prato e seus talheres pagava I dólar a menos; quase todos estavam com seus pratos e talheres na mão, enquanto esperavam na fila para serem servidos. 

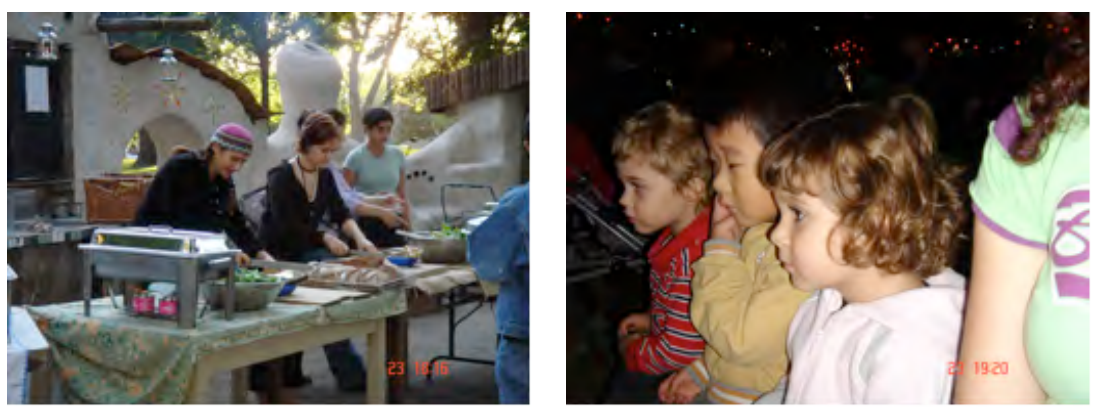

\section{Night of Dread 33}

Participamos ainda de mais uma atividade nesse parque que foi a confecção de bonecos para uma festa chamada Night of Dread. A idéia dessa festa é ter um dia para espantarmos nossos medos. Os bonecos que aparecem nas fotos abaixo foram confeccionados durante as semanas anteriores ao evento, alguns no próprio parque, por qualquer pessoas que se interessasse em participar. $\bigcirc$ evento teve a colaboração da prefeitura, de um grupo de teatro de rua e de um grupo de maracatu, contando sempre com a Associação de Amigos do Parque como organizadora.

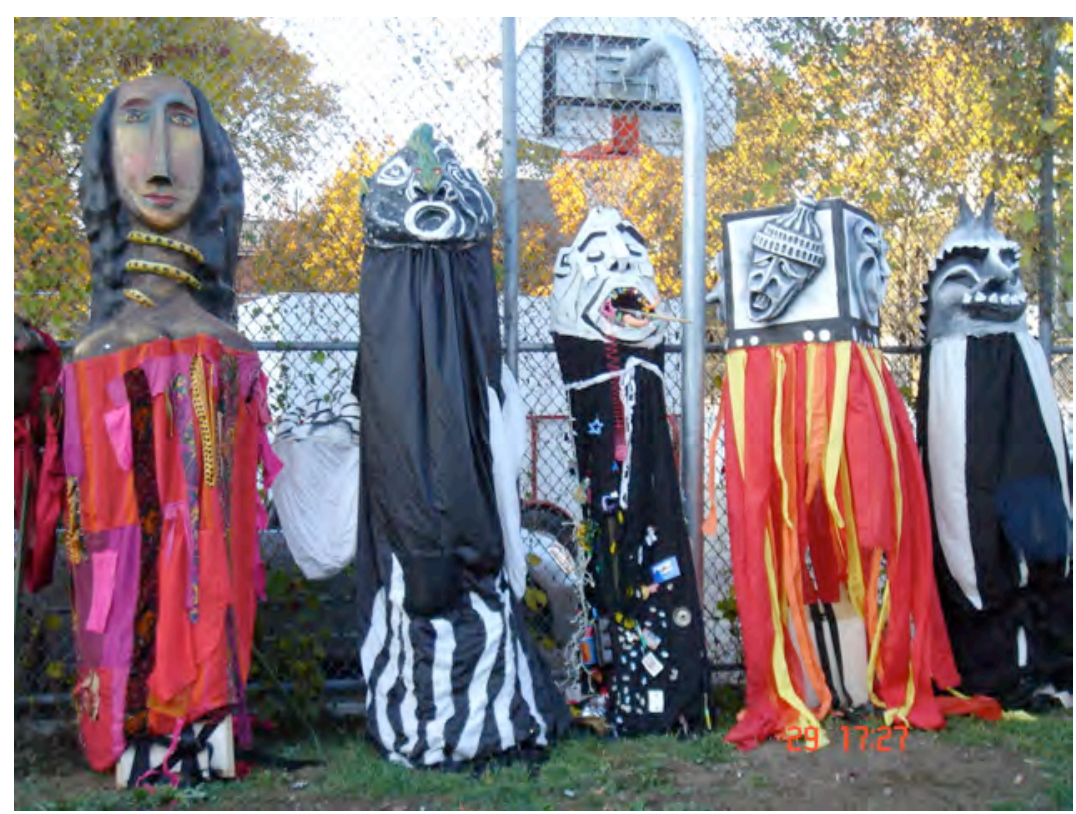

33 "Noite do Terror" 

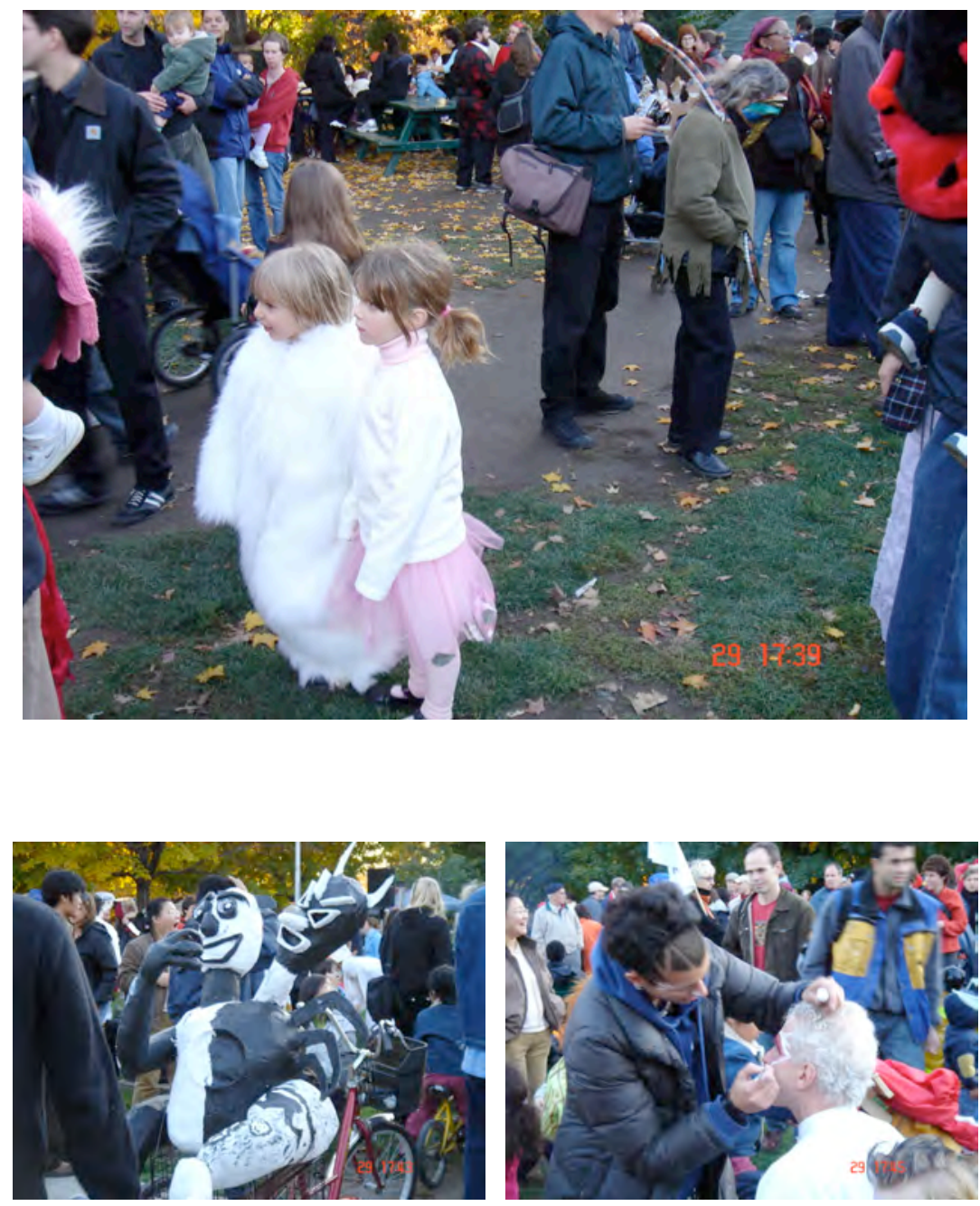

Em todas essas atividades em áreas públicas sempre há muitas crianças.

Familias freqüentam o parque e as atividades e festividades que ocorrem ali fazem parte de seus programas de lazer. Eles participam da organização dos eventos, de discussões com a prefeitura sobre a poda das arvores, negociam com a prefeitura parcerias para viabilizar suas propostas como por exemplo o dia da pizza. A comunidade se organizou para cozinhar no parque e a prefeitura quis proibir por falta de condições sanitárias e de higiene; a população então reivindicou parceria: vocês cuidam da infra-estrutura - água, luz e forno - e nós fazemos as pizzas. Assim ficou combinado e assim funciona. Novamente aqui as atividades acontecem numa escala pequena.

As fotos abaixo são da montagem de uma construção típica do Uzbequistão que o parque ganhou de morador do bairro imigrante desse país; ela é remontada pela comunidade todos os verões. No inverno precisa ser desmontada 
devido às condições climáticas locais (muita neve). Aqui de novo a história presente; neste caso, a história trazida para lá de um lugar muito distante.
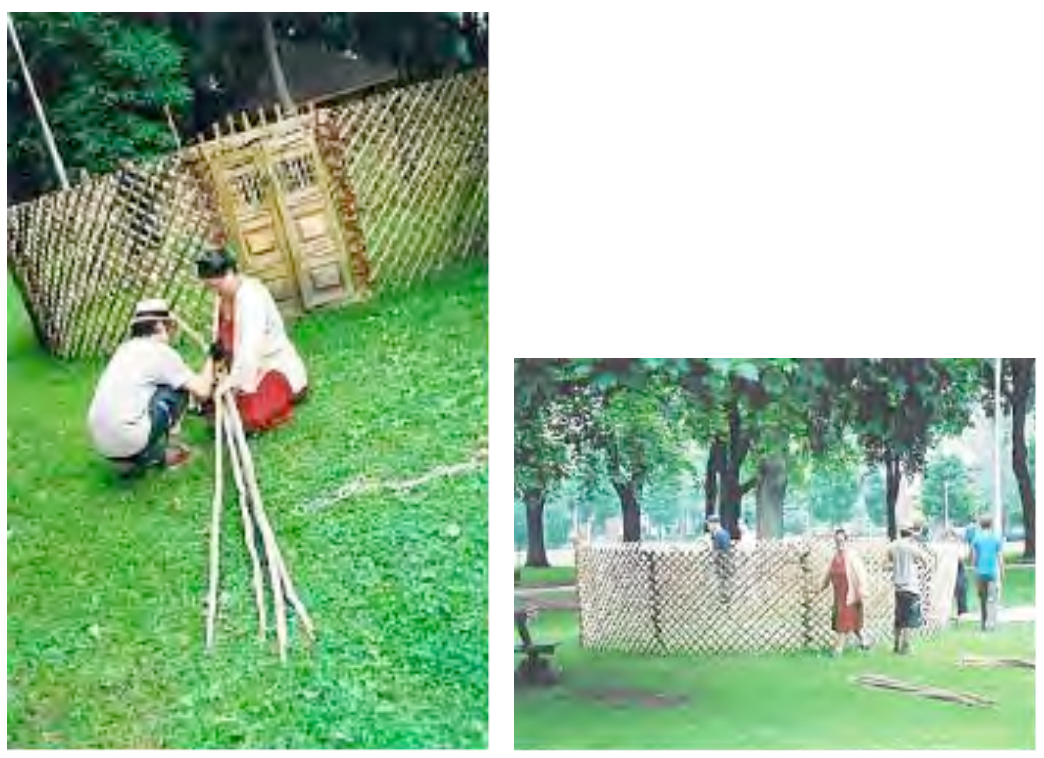

Um aspecto fundamental observado em todas as atividades deste parque é a existência do diálogo entre o poder público, profissionais e a comunidade, para que a gestão do lugar se dê de maneira a garantir sua continuidade, enriquecer a experiência de todos os participantes e propiciar-Ihes vivências satisfatórias, prazerosas e enriquecedoras. $\bigcirc$ parque tem uma Sociedade de Amigos que o administra, faz contato com a prefeitura, cuida dele: organiza eventos culinários, artísticos, de lazer, e outros. No momento estão trabalhando na construção de um bio-sanitário ${ }^{34}$ que inclusive está entre os finalistas do "Prêmio Toronto Verde", instituído pela Prefeitura da cidade; ele será feito de adobe e contará com a participação das crianças; seu projeto já foi aprovado pela prefeitura e atenderá ao parquinho.

\section{HERITAGE WALKS 35}

São caminhadas por percursos da cidade que tenham algum significado para a sua história; elas são guiadas por voluntários, residentes, que recebem da

\footnotetext{
34 "bio-toilet"

35 "Caminhadas Históricas" (tradução livre) - site: www.heritagetoronto.org
} 
prefeitura preparação e infra-estrutura para desenvolver esse trabalho - folhetos explicativos a serem distribuídos aos participantes e uma espécie de megafone para que todos possam escutar as histórias, as explicações. Os folhetos contêm o circuito a ser percorrido e a história dos pontos de interesse. Participei de duas dessas caminhadas: "Tesouros Escondidos em North Rosedale", que é um bairro muito rico, e "De Vila a Cidade: o bairro St. Lawrence".

Na primeira, os pontos de interesse eram casas que tiveram alguma importância, histórica ou arquitetônica, na cidade. Casas projetadas por arquitetos famosos (John Lyle, por exemplo), casas onde moraram pessoas que tiveram alguma importância na história ou economia da cidade. $\bigcirc$ guia nos contou a história do bairro, as implicações de sua criação sobre, por exemplo, obras que a cidade precisou pagar para criar a infra-estrutura para os moradores de lá - um viaduto novo e linhas de ônibus novas.

Na segunda, em que caminhamos pelo centro histórico da cidade, os pontos de interesse eram prédios públicos e institucionais, preservados pelo instituto de patrimônio histórico local: o primeiro prédio dos correios, da polícia e do primeiro grande jornal da cidade - que tem um enorme mural com imagens da formação da cidade -, dos escritórios de um importante comerciante que viveu quando a cidade foi fundada, e outros. $\bigcirc$ guia, além de contar a história do lugar, responde a perguntas feitas pelos participantes.

A grande maioria, se não a totalidade das pessoas que participaram dessas caminhadas históricas eram moradores de Toronto, adultos e ambos os grupos tinham por volta de 30 pessoas.

Apesar de não serem atividades de projeto participativo, decidimos incluí-las nestes nossos relatos pois elas oferecem algumas contribuições para nossas reflexões. Essas caminhadas são atividades que enriquecem o conhecimento da história dos lugares da cidade visitados. E como dissemos anteriormente, saber a história de um lugar é fundamental para a sua compreensão. Chamou a nossa atenção o fato de a grande maioria dos participantes serem moradores de Toronto, ou seja, essa não era uma atividade especialmente dirigida a turistas. Havia uma 
série delas, passando por sítios arqueológicos, culturais, naturais e construídos parques, campus universitário, velhas fábricas, antigas trilhas que deram lugar a ferrovias, e assim por diante. São oportunidades oferecidas aos residentes, pela prefeitura, com a contribuição de outros moradores, de melhor conhecer a sua cidade através da sua história natural, cultural, patrimonial e de arquitetura.

\section{Algumas considerações}

Grupos pequenos permitem a participação mais efetiva das pessoas, facilitando e acolhendo perguntas, comentários e dúvidas individuais; o fato de os guias serem voluntários moradores da própria cidade, aproxima os participantes, fazendo com que a conversa se dê 'de igual para igual'; as pessoas gostam de ouvir histórias; ouvir histórias referentes a um lugar que se visita faz muito sentido e facilita sua compreensão e apreensão.

\section{DISCOVERY WALKS 36}

Outra atividade oferecida pela prefeitura da cidade de Toronto são os Discovery Walks. São percursos pensados para serem percorridos de forma autoguiada. Existem folhetos, um para cada circuito, com as seguintes informações: breve descrição do percurso, e seus pontos de interesse, mapa com pontos referenciais e escala, orientação (norte), tempo de duração da caminhada, vistas interessantes, transporte público, acessos, declividade do terreno, pontos de acessibilidade universal, dicas gerais.

\section{'CAR-FREE DAY' - CONCORD STREET ${ }^{37}$}

Um domingo, em uma rua de tráfego usual bastante reduzido para os padrões de São Paulo, aconteceu o 'Dia sem Automóveis'. A rua foi fechada pela prefeitura e os moradores passaram o dia fazendo atividades na rua e com as

\footnotetext{
36 "Caminhadas Exploratórias"

37 'Dia sem automóveis' - Rua Concord
} 
portas de suas casas abertas. Havia muitas crianças e foram organizadas algumas atividades - lanche, pipoca, bolhas de sabão, bicicletas, triciclos, pintura facial, entre outros - com a participação de alguns palhaços e familiares. As pessoas que compareceram eram basicamente moradores, e o ambiente era absolutamente calmo, como se pode ver nas fotos abaixo.
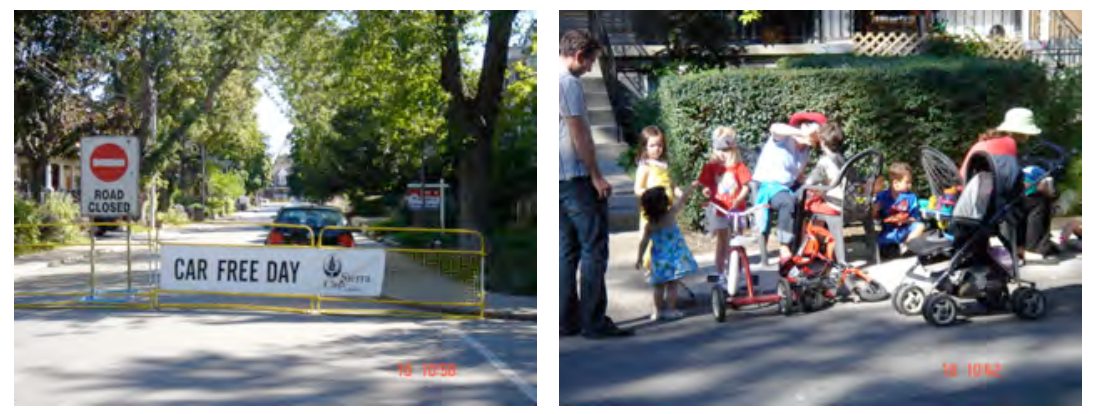

\section{TORONTO MUSIC GARDEN}

Este é uma jardim muito especial, desenhado pela arquiteta paisagista Julie Misservey em colaboração com o violoncelista Yo-Yo Ma. É um jardim que fica às margens do Lago Ontário, e seu projeto foi inspirado pela Suíte $n^{\circ}$ I de Bach. Há um programa de visita guiada, este também promovido pela prefeitura, em colaboração com voluntários residentes, para se conhecer o jardim e sua história, ao som da suíte que o inspirou. É uma atividade muito simples, e que nos oferece informação e prazer.

O caráter é o mesmo das Heritage Walks, mas com foco no Jardim.
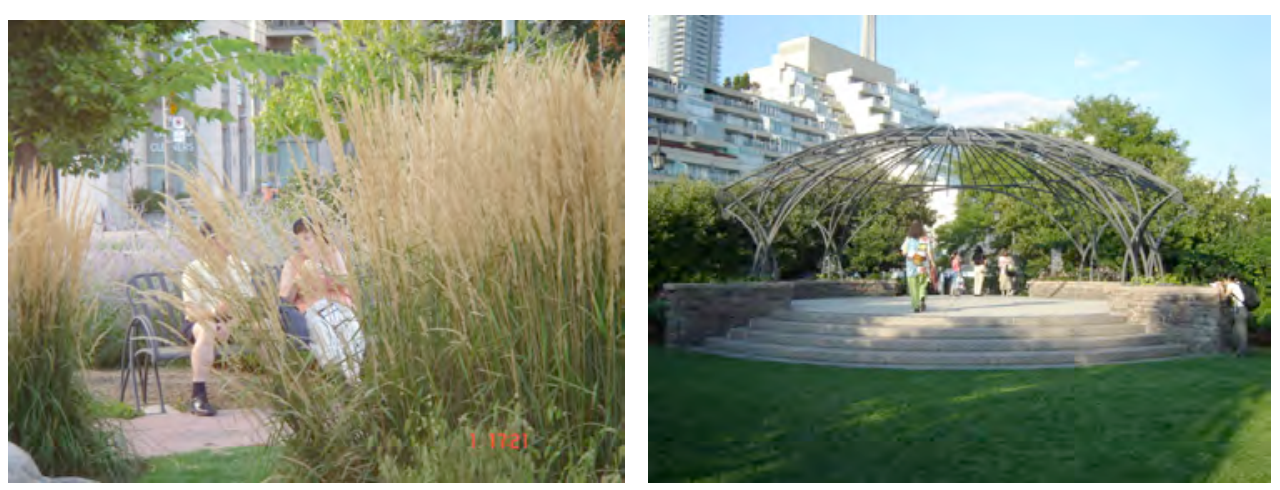


\section{GROWING UP IN CITIES (GUIC)}

O Projeto Growing Up in Cities é uma iniciativa da UNESCO, em parceria com a Universidade Cornell, em Ithaca, EUA. Seu objetivo primeiro é transferir descobertas e dados relevantes das Ciências Sociais a tomadores de decisão e outros interessados. Ele se iniciou em 1970, por iniciativa de Kevin Lynch, planejador urbano americano e diretor do projeto original, que dizia que "[u]ma boa cidade é aquela na qual a criança pode crescer e se desenvolver na medida de suas potencialidades, onde ela possa construir confiança e tornar-se ativamente engajada no mundo, e ainda assim ter autonomia e capacidade de cuidar de seus próprios assuntos."

Os objetivos primeiros do GUiC são:

- mostrar o uso e a percepção de crianças e jovens sobre seu ambiente e como ele afeta suas vidas;

- construir capacidade de pesquisa localmente - com e envolvimento de crianças - para alimentar políticas locais e nacionais;

- desenvolver indicadores ambientais sobre experiências urbanas de crianças;

- $\quad$ estabelecer referências para acompanhar alterações nas condições das crianças;

- mobilizar apoio público para melhorias;

- passar da pesquisa para a ação;

- construir redes, no eixo Norte-Sul, de equipes do projeto e defensores de crianças.

O programa considera as seguintes fases de trabalho em cada local onde se forme um grupo: formação de equipes de pesquisa-ação; formação de rede com simpatizantes do governo, ONGs, instituições educacionais, mídia, e comunidade; pesquisa-ação; implementação de prioridades factíveis e treinamento.

A iniciativa "... promove a educação para a ação. Ele oferece oportunidades a jovens para desenvolver habilidades para suas vidas e conquistar auto-confiança, através do envolvimento na melhoria dos espaços públicos de seus locais de vida: 
os mesmos lugares onde precisarão demonstrar responsabilidade social e ambiental e capacidade para a ação democrática quando se tornarem adultos." ${ }^{138}$

Alguns documentos internacionais orientam o Projeto, a saber:

- Convenção dos Direitos da Criança ${ }^{39}$, UNICEF (1989)

- $\quad$ Homem e a Biosfera $(M A B)^{40}$, UNESCO (1968)

- Eco 924l e 'Agenda 2l'42 (1992)

- $\quad$ Prefeitos, Defensores das Crianças ${ }^{43}$, UNICEF (1992)

- MOST Programme ${ }^{44}$, UNESCO (1993)

- Habitat II 'City Summit' (1996)

Vale aqui destacar alguns artigos do primeiro deles, de 1989:

"Artigo 12: A criança tem o direito de expressar livremente suas opiniões e de tê-las levadas em consideração em qualquer assunto ou ação que a afete."

"Artigo 13: A criança tem o direito de expressar seus pontos de vista, obter informações, tornar idéias ou informações conhecidas, independentemente de fronteiras."

"Artigo 14: O Estado deve respeitar os direitos da criança à liberdade de pensamento, consciência e religião, de acordo com orientação paterna e materna apropriadas."

"Artigo 15: A criança tem direito `a liberdade de associação e reunião pacífica."

\footnotetext{
38 do site www.guic.org

39 http://www.unicef.pt/docs/pdf_publicacoes/convencao direitos crianca2004.pdf

40 http://www.unesco.org/mab/mabProg.shtml

${ }^{41}$ http://pt.wikipedia.org/wiki/ECO-92

${ }^{42}$ http://www.un.org/esa/sustdev/documents/agenda2//index.htm

43 http://www.unicef.org/brazil/sowc03/cap6.html

${ }^{44}$ http://www.unesco.org/shs/most

45 http://portal.unesco.org/shs/en/file download.php/aba89934f4e l 2148a803ef6e0c44cc06note dg 
"Artigo 29: A educação deve almejar o desenvolvimento da personalidade, talentos e habilidades mentais e físicas em sua plena potencialidade. A educação deve preparar a criança para uma vida adulta ativa numa sociedade livre e deve impulsionar o respeito pelos pais das crianças, sua identidade cultural, linguagem e valores e pelo background cultural e valores de outros."

Um item da Agenda 21:

"Capítulo 25. I3(b): Governos nacionais, de acordo com suas políticas, devem tomar medidas para... garantir que os interesses das crianças sejam inteiramente levados em consideração nos processos participativos para o desenvolvimento sustentável e a melhoria ambiental."

E ainda outro da Agenda do Habitat:

"As necessidades das crianças e dos jovens devem ser totalmente levadas em consideração... Deve se prestar atenção especial a processos participativos que lidam com a conformação das cidades e bairros... para garantir condições seguras de vida de crianças e jovens e utilizar suas idéias, criatividade e pensamentos sobre o ambiente."

Jovens e crianças em geral não acreditam que suas opiniões serão levadas a sério; mas quando estabelece-se a confiança na relação com eles, são capazes de elaborar idéias, sugestões, pensamentos bastante originais e elaborados.

Alguns resultados de trabalhos de grupos do GUiC podem nos informar que na perspectiva de crianças de 10 a 14 anos, algumas importantes qualidades urbanas são: a integração social (companheirismo, sensação de pertencimento e aceitação, por parte dos adultos), locais para atividades interessantes e variadas, sensação de segurança e liberdade de movimento, locais de encontro com seus pares, identidade coesa e positiva da comunidade, áreas naturais, provisão de necessidades básicas, propriedade segura de terra e tradição de organização comunitária e auto-ajuda. Podemos ainda observar que algumas das questões consideradas como desvantagens, ou aspectos negativos da cidade são o estigma e a exclusão, o tédio, o medo do crime, o grande número de veículos, as tensões étnicas ou raciais, a sensação de impotência política e a falta de serviços básicos. 
Foram identificados ainda alguns benefícios da participação: processos participativos podem ajudar na contraposição à sensação de marginalização e estigma pela pobreza.

"Ele (o projeto) nos ensinou que pessoas podem ajudar a mudar a sua vida..."

participante do GUiC em Johanesburgo, África do Sul.

"E então eu fiquei tão orgulhosa por todos nós."

participante do GUiC, oficina do prefeito de Johanesburgo

Alguns resultados dos trabalhos já feitos até aqui pelo $\mathrm{GUiC}^{46}$ apontam para a harmonia entre as prioridades das crianças e o desenvolvimento sustentável ${ }^{47}$ : comunidades fortes, culturas locais vivas; áreas verdes; ruas seguras e transporte público; pessoas amistosas, locais de encontro; serviços básicos; segurança e esperança; e governança participativa.

No período em que estive no Canadá, tive a oportunidade de visitar o prof. David Driskell ${ }^{48}$ e à sua equipe de alunos. Esse grupo havia desenvolvido atividades do GUiC na cidade de Nova lorque com dez comunidades de jovens. Esse trabalho nos foi apresentado pelos alunos coordenadores de cada um dos grupos que, por sua vez, eram ligados a associações locais e discutiam questões de seu bairro tais como lixo, gentrificação entre outros. Nesse momento foi renovado um convite para participarmos da iniciativa montando um grupo de trabalho em São Paulo e surgiu a possibilidade de algum aluno do grupo vir ao Brasil para apresentar o GUiC. Isso foi em outubro de 2005, e em janeiro de 2006 Carly Fox, coordenadora de um dos grupos de Nova lorque, veio fazer esse trabalho, que está relatado mais adiante.

${ }^{46} \mathrm{O}$ GUiC tem grupos de trabalho em todos os continentes. (CHAWLA, 2002)

${ }^{47}$ Não cabe aqui a discussão desse conceito, sobre o qual existem muitas controvérsias; vamos considerar a definição "desenvolvimento sustentável é aquele que satisfaz as necessidades das atuais gerações sem prejudicar o potencial natural para a satisfação das futuras gerações".

48 chefe da cadeira da UNESCO na Universidade Cornell, para o GUiC. 


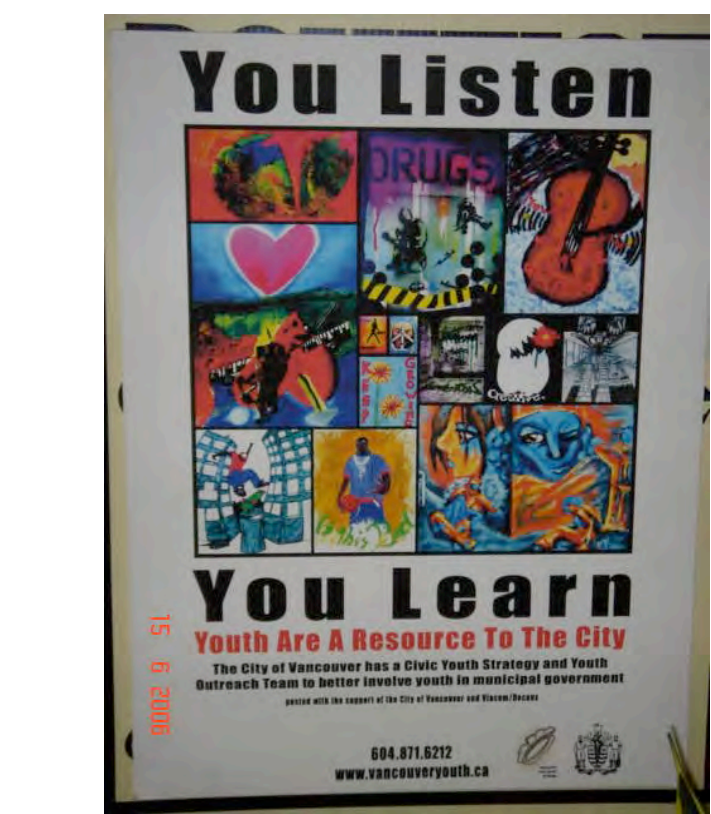

Cartaz do Youth Urban Forum 2006, em Vancouver

\section{Você Escuta \\ Você Aprende}

Jovens são um Recurso para a Cidade.

A Cidade de Vancouver tem uma estratégia cívica para os jovens e uma equipe para se comunicar com os jovens para melhor envolvê-los no governo municipal.

\section{Oficina GUiC em Vancouver}

Em junho de 2006 recebi convite do GUiC para participar do encontro que ocorreu em Vancouver, Canadá: o décimo aniversário do GUiC (GUiC + I0). Nesse encontro trabalhamos com participantes adultos, jovens e crianças de Manila/Filipinas, Tóquio/Japão, Sarajevo/Bósnia, Cook Islands, Sidney/Austrália, Oslo/Noruega, Ithaca/EUA, Denver/EUA, Guadalajara/México, Quebec/Canadá, Montreal/Canadá para redefinir as diretrizes do GUiC. A partir de oficinas e discussões produzimos um documento com as diretrizes básicas da iniciativa. (ANEXO VI), pois como a rede GUiC está se ampliando bastante após 10 anos de trabalho, surgiu a necessidade de explicitar e redefinir os princípios e diretrizes da iniciativa para todos os participantes. 


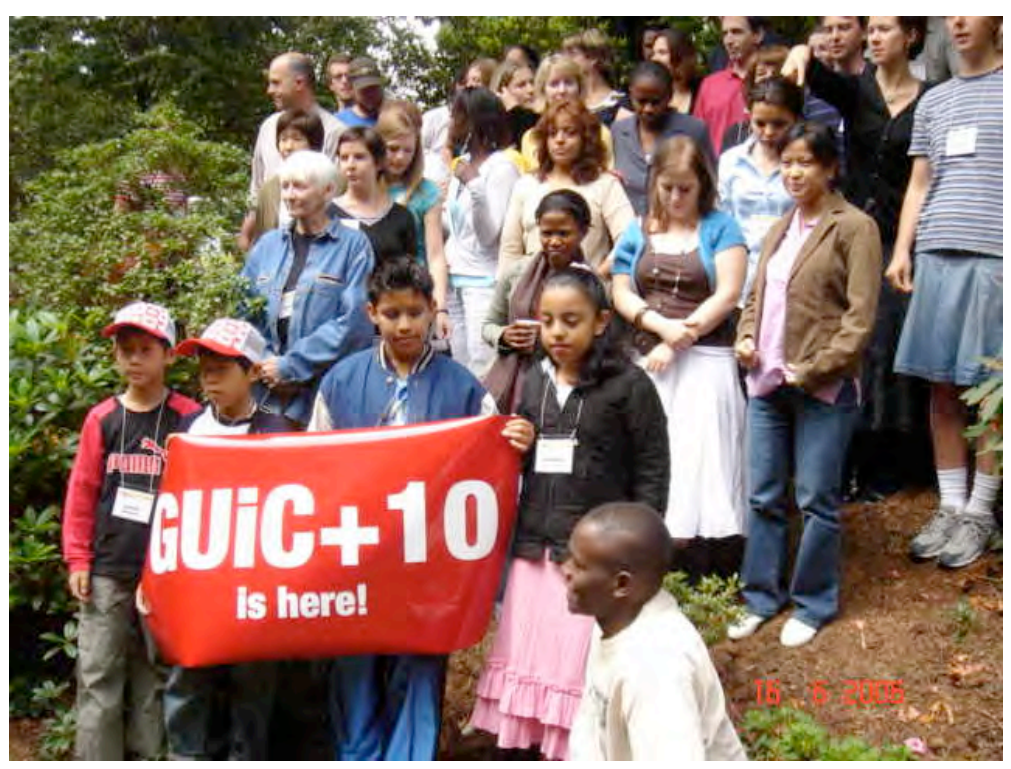

Final dos trabalhos em Vancouver no encontro do GUiC

Os objetivos dessas oficinas, que tinham um caráter participativo, eram: formar um grupo de trabalho, conhecer a iniciativa Growing Up in Cities e estabelecer os passos para o estabelecimento de um grupo em diferentes países. Discutiu-se objetivos do projeto, experimentou-se a metodologia GUiC, conversou-se sobre expectativas, projetos pessoais e a importância da participação de jovens em discussões e ações que afetem diretamente seus lugares de vida, suas vidas.

\section{Oficina GUiC em São Paulo}

Em janeiro de 2006, então, Carly Fox, mestranda da College of Architecture, Art e Planning, da Universidade Cornell, aluna do professor Driskell, veio ao Brasil para coordenar uma oficina com pessoas interessadas em conhecer a iniciativa Growing up in Cities e eventualmente integrar uma equipe do projeto em São Paulo. Participaram dessas oficinas sete alunos de pós-graduação integrantes do Programa Bacias Irmãs, um aluno de pós-graduação da FAU USP, dois alunos de graduação da FAU USP, uma aluna de graduação da Faculdade de Educação da USP, uma aluna de graduação em Administração Pública da Fundação Getulio Vargas, uma professora de geografia da Rede Pública de Ensino Fundamental Municipal e uma professora de geografia, integrante de uma Associação de Bairro na bacia do Córrego Pirajussara. 


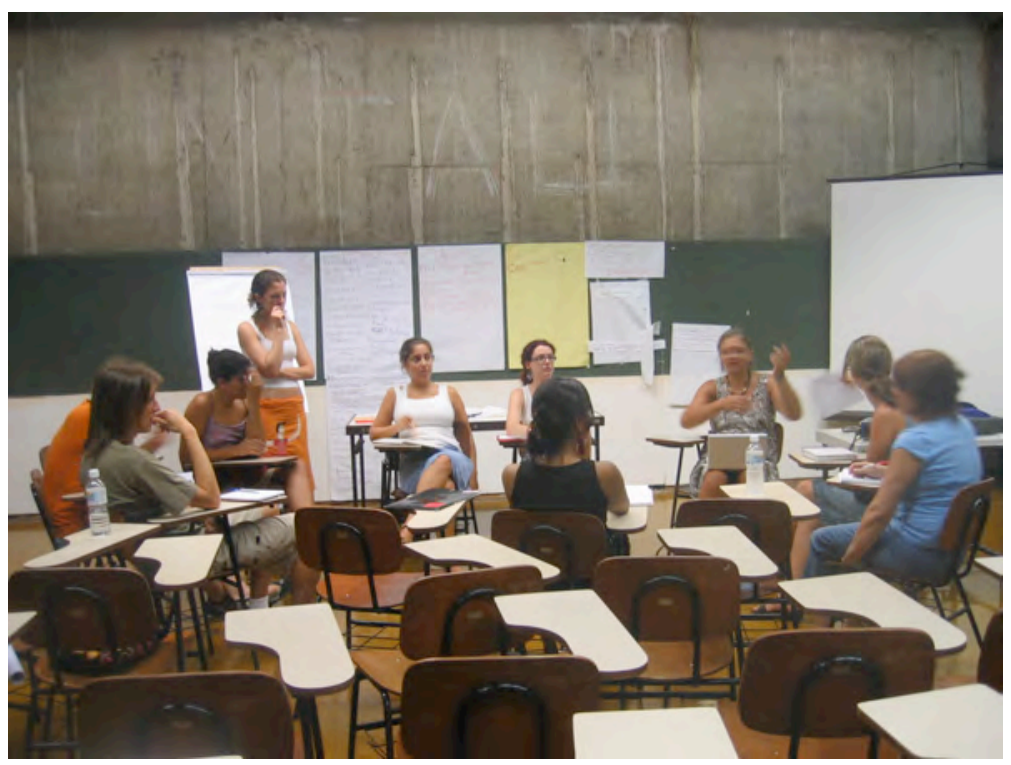

Foram cinco dias de trabalho para os quais foi preparada uma agenda flexível, a ser re-discutida conforme o andamento diário do processo. Os objetivos gerais eram apresentar, em forma de oficinas participativas, a iniciativa Growing Up in Cities, seus princípios e metodologias, buscando identificar possibilidades de organização de uma equipe para agir dentro do seu escopo, em São Paulo. E a partir disso, conhecer todos os participantes do grupo interessado, saber que instituição representava, o que fazia, suas experiências em trabalhos com jovens, e/ou pesquisa-ação, aspectos de sua juventude.

A programação incluiu apresentações pessoais e de expectativas, relatos de outros projetos dos participantes, apresentação da teoria e prática da participação cidadã de jovens, a metodologia GUiC, oficinas para identificação e discussão de temas significativos para o grupo49 e oficinas de experimentação das atividades de pesquisa-ação propostas pelo GUiC. Estas últimas foram feitas em grupos de quatro pessoas e depois compartilhadas e discutidas (objetivos, instruções, etc.) pelo grupo todo.

Serão expostos aqui apenas alguns dos temas debatidos nos encontros. Um aspecto importante discutido durante os trabalhos foi a necessidade de identificação de potenciais recursos (financeiros e outros) e parceiros locais, e de projetos

${ }^{49}$ Algumas das atividades das oficinas estão no Anexo VIII. 
internacionais similares como os de Nairóbi, Manila/Filipinas, Sarajevo/Bósnia, o World Urban Forum e Youht Urban Forum no Canadá. Os primeiros, para garantir a viabilidade do projeto - seja ele de qualquer escala - e os últimos para estabelecer parceiros com quem se possa trocar experiências, construir conhecimento e uma rede de parceiros.

Em uma das oficinas, que estimulava a memória com relação à adolescência, os desenhos e histórias de cada um suscitaram as seguintes questões: brincadeira, os pais perto, bebida, rebeldia, liberdade, sair da rotina, lugares diferentes, curiosidade, muita energia, autonomia, busca da própria rotina, querer ser adulto, desejo de ficar "fora", despreocupação, independência, espaço urbano, sensação de conforto em relação ao espaço, clube, espaço aberto, amigos próximos, limite, natureza, animais, vida, família, professora boa (aula de geografia), aprender, sítio, pessoas diferentes, amizades, viajar, inocência, auto-afirmação, amigos, fora da escola, rito de passagem, homogeneidade, tédio, pátio pequeno, despreocupação, sensação de conforto em relação ao espaço, espaço aberto, organização (também de conhecimento), escola, bairro, usar transporte público, restaurante fast-food, frio, discussão de regras, sair/passear/"dar um rolê", mudança, ruptura. Essas questões foram organizadas por assunto para posterior discussão. Foram então levantadas muitas dúvidas, apontando para a importância da significação de cada um desses temas para cada pessoa.

Ainda uma outra oficina buscou levantar questões, dúvidas e expectativas com relação ao GUiC. Surgiram as seguintes, que foram colocadas em discussão:

- O que significa um projeto 'terminado'? Uma vez que este é realizado o GUiC não trabalha mais com esses jovens?

- O que significa ser do GUiC?

- Como se começa um processo? Poder público "contrata"? Comunidade pede ajuda?

- Qual é/Como é/Tem ligação com a universidade?/Qual é/Como é

- Tem limite de crianças/jovens?

- [Carly], pela sua experiência já houve questões étnicas?

- O que fazer/Como fazer para realmente "dar certo"? Resultados concretos? 
- Qual a relação que a universidade tem com o GUiC?

- Qual a relação que o poder público tem com o GUiC?

- Como será decidido o tema a ser trabalhado com o grupo?

- Como convencer os grupos a participar?

- Qual é o papel dos líderes? Quem serão os líderes? Eles devem sair junto com os grupos durante os exercícios? Devem participar?

- Devemos dizer a eles o que sabemos? Ou só esperar deles? Só trabalhar para que o conhecimento seja construído por eles, sem colaboração nossa?

- Qual o objetivo do planejamento participativo?

- É importante envolver jovens? Por que? Ou por que não?

- Quais são as vantagens da pesquisa participativa?

- Quais são os desafios?

- Qual a importância da participação de jovens?

Algumas das conclusões do grupo foram:

- $\quad$ a finalização de um projeto depende dos objetivos e metas. Ela não pode ser definida a priori;

- $\quad$ é importante a formação de líderes, pessoas que possam dar continuidade ao processo;

- $\quad$ o ganho de cada envolvido é a ampliação do universo, do conhecimento, da cultura, e o tornar-se protagonista de uma rede;

- para o convencimento das pessoas: criação de um repertório das atividades; criação de uma rede entre municípios; oficinas, aulas, arte-educação;

- um desafio é a criação de uma rede para as trocas entre pesquisadores (não só coordenadores).

\section{Algumas considerações}

As duas experiências vividas no âmbito do GUiC foram de preparação e estudo e não de ação junto a jovens, apesar de na primeira delas, ter havido a participação de jovens e crianças discutindo e apresentando trabalhos desenvolvidos em seus respectivos países - havia um grupo de crianças do Japão e outro de jovens do México. 


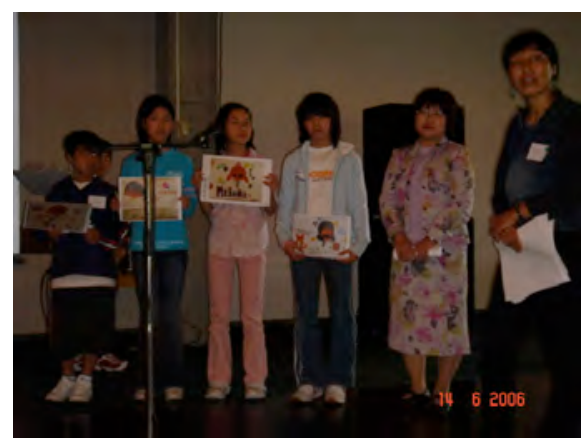

Grupo do Japão apresentando seu projeto para uma área livre próxima de sua escola

Foi muito significativo e esclarecedor na primeira delas, que ocorreu em Vancouver, e que contou com a participação de profissionais que já atuaram segundo as diretrizes do GUiC, observar como todas as atividades eram estritamente participativas. Trabalhamos juntos durante quatro dias e a coordenação, a produção, a operacionalização, o registro e o encaminhamento dos trabalhos eram discutidos, divididos e compartilhados entre os participantes; e todas as decisões eram tomadas em consenso.

$\mathrm{Na}$ experiência do Brasil tivemos a oportunidade de experimentar um processo de discussão das diretrizes, das orientações, dos princípios, das possibilidades, da metodologia do GUiC, também através de um processo participativo. Desde a proposta, até as conclusões, passando pela organização, produção e registro das atividades, tudo foi feito de forma conjunta, contando com a contribuição de todos.

Pudemos notar, através dos relatos da adolescência de cada um, como as vivências individuais são fortes motores para que as pessoas se interessem e se identifiquem com temas que poderiam, de outra forma, ser tratados de forma distanciada e portanto sem significação.

$$
\text { 虾弥 }
$$

No próximo e último capítulo trataremos de abordar questões suscitadas por todas essas experiências, buscando organizá-las e discutir alguns aspectos que possam contribuir com o conhecimento relativo a praticas participativas com jovens, na paisagem. 
CAPÍTULO 3

Polifonia Adolescente 
"À Firmini, nous avons mis des fontaines. Les gosses qui s'amusent avec l'eau tombant des fontaines le feront durant des générations et ça compte! Dans le calcul de rentabilité, pourquoi ne ferait-on pas entrer le sourire des enfants?"|

Charles Delfante, urbanista francês

\section{JOVENS EM AÇÃO}

Este capítulo trata da questão principal deste trabalho: de que forma nós, arquitetos paisagistas podemos contribuir para tornar o jovem dono de sua história, e portanto na sua formação como cidadão, emancipá-lo, tornando-o sujeito de sua ação. Qualquer transformação no âmbito social e ambiental urbano depende de inúmeras ações concorrentes e complementares, e nossa contribuição pode ser apenas uma pequena fração desse processo - no entanto, não irrelevante.

Os espaços livres públicos na cidade são locais de encontro, de ver e ser visto, de fazer esporte, namorar, descansar, ler, tomar sol, caminhar, se divertir, ter contato com a natureza, relaxar. Os jovens têm a energia e a vitalidade característica e específica que apenas o uso ativo de um grupo heterogêneo de pessoas, compartilhando um espaço para atividades diversas, pode oferecer. "Uma cidade, por sua própria natureza, não é possuída; ela é compartilhada. $\bigcirc$ espaço público é propriedade pública. Especialmente para aqueles de nós - e há muitos sem condições de comprar uma propriedade privada, um apartamento ou uma casa para chamar de 'minha', o espaço público é extremamente importante. ...O público é o privado e vice-versa, sempre. Propriedade também implica responsabilidade, e a

\footnotetext{
I "Em Firminy, instalamos fontes. Os guris que se divertem com a água que jorra das fontes assim o farão por gerações e isso conta! No cálculo de rentabilidade, por que não contabilizaríamos o sorriso das crianças?" (Publicado no L'Express, em 24 de novembro de 1969) - in MESMIN, 197I.
} 


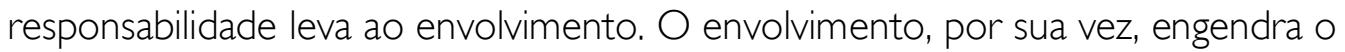
crescimento."' (MCBRIDE, 2005: II)

Existe um movimento mundial no sentido de se envolver a população na discussão de projetos e gestão de espaços públicos; é fundamental que essas pessoas estejam preparadas para essa participação e participar é algo que se aprende fazendo. $\mathrm{U}$ N-Habitat ${ }^{3}$, um dos programas da $\mathrm{ONU}$ que trabalham com projetos participativos na discussão das cidades, tem como missão "...promover o desenvolvimento social e ambientalmente sustentável de assentamentos humanos e a obtenção de abrigo adequado para todos.." Em seus documentos podemos observar a primordial importância dada à participação da população local em projetos para os lugares onde vivem. Os projetos são entendidos como ferramentas de reflexão e negociação e servem de instrumentos ativos através dos quais sugestões podem ser absorvidas, processadas e incorporadas, alternativas geradas e conflitos resolvidos. "Eles [os projetos] são suficientemente enraizados na realidade local e baseados no conhecimento local reconhecido e apropriado pelas pessoas para quem eles são feitos." ${ }^{5}$ LOECKX (2004)

A preparação, capacitação, habilitação e organização para essa participação são necessárias e isso se dá através da prática, do envolvimento contínuo em processos dessa natureza, acertando e errando, discutindo com outros grupos de interesse e com seus pares, avaliando encaminhamentos, ferramentas de trabalho, estratégias e resultados obtidos. É preciso que haja uma mobilização da reflexão crítica e quanto mais cedo as pessoas tiverem a oportunidade de participar de processos de discussão de seus lugares de vida, tanto antes desenvolverão suas

\footnotetext{
2 "A city, by its very nature, is not owned; it is shared. Public space is public property. Especially for those of us - and there are many - unable to afford private property, a condo or house to call our own, public space is extremely important. ... The public is private and vice versa, always. Ownership also implies responsibility, and responsibility begets contribution. Contribution, in turn, engenders growth."

${ }^{3}$ United Nations Human Settlements Programme

4 "...to promote socially and environmentally sustainable human settlements development and the achievement of adequate shelter for all."

5 "They are also sufficiently rooted in local reality and based on local social knowledge recognized and appropriated by the people for whom they are intended."
} 
habilidades e potencialidades para tal. Jovens e crianças têm um enorme potencial e existem inúmeras possibilidades de se trabalhar em parceria com eles para desenvolvê-lo as quais vamos discutir mais adiante.

Processos que envolvem jovens nas discussões relativas a questões que thes dizem respeito são muitos. $O$ programa Voices of Youth ${ }^{6}$, da UNICEF, tem uma grande quantidade de projetos em andamento pelo mundo todo. Em março de 2006, por exemplo, aconteceu o $2^{\circ}$ Fórum Infantil Mundial da Água, durante o $4^{\circ}$ Fórum Mundial da Água, na Cidade do México, que foi um encontro importante de crianças sobre água, sobrevivência e educação. "Cento e sete jovens ativistas ligados à questão da água, de vinte e nove países de todo o mundo, encontraram-se com ministros para discutir como as crianças podem ajudar a resolver a crescente crise mundial da água."” A Convenção dos Direitos das Crianças, das Nações Unidas (Anexo X), elaborada em 1989 e ratificada pelo Brasil em 1990, defende o direito da criança à participação em assuntos que digam respeito à sua vida, afirmando que elas devem sempre ser ouvidas. $\bigcirc$ mesmo deve ser considerado para os jovens.

"O UN-Habitat reconhece os jovens como participantes ativos no futuro dos assentamentos humanos. A juventude de hoje já está concebendo, elaborando e implementando projetos de sucesso de consolidação comunitária em algumas das regiões mais marginalizadas do mundo. Os jovens precisam de reconhecimento, orientação e treinamento, para desenvolver todo o seu potencial. Em resposta, o UN-Habitat toma a iniciativa, e impulsiona a interação e as parcerias com organizações de jovens. Engaja jovens a nível internacional na ajuda da formulação de uma compreensão internacional das questões prementes dos jovens. Trabalhar com jovens homens e mulheres e compreender suas diversas habilidades, realidades e experiências, é um elemento essencial para o sucesso a longo prazo do UN-HABITAT em conseguir a urbanização sustentável.".

\footnotetext{
6 "Vozes dos Jovens"

${ }^{7}$ http://www.unicef.org/voy/index.php

8 "UN-HABITAT recognizes young people as active participants in the future of human settlements.
} Today's youth are already conceiving, designing and implementing successful community-building projects in some of the most marginalized regions of the world. Young people need acknowledgement, guidance and training in order to 
É muito significativa do momento atual a última frase de Anna Tibaijuka Sub-Secretária-Geral das Nações Unidas e Diretora Executiva do UN-HABITAT, em seu discurso na cerimônia de abertura do Dia do Jovem Empresário, em Nairobi, no dia 15 de abril de 2007: "...nós estamos ouvindo vocês."

Um outro exemplo do envolvimento dos jovens em discussões sobre suas cidades é o Fórum Urbano Mundial da Juventude, que aconteceu em junho de 2006, em Vancouver, no Canadá, paralelamente ao Fórum Urbano Mundial. Uma das mesas redondas deste último - Jovens Líderes de Hoje e Amanhã - foi uma das maiores, com a participação de mais de 500 jovens e aliados adultos. $\bigcirc$ tema prevalente foi a necessidade do UN-HABITAT e de outras instituições passarem do envolvimento simulado da juventude para um real engajamento dos jovens em todas as etapas do planejamento de programas e políticas públicas - seus projetos, implementação, avaliação e continuidade. Esse encontro revelou a disposição, a vontade, a energia dos jovens para participar das discussões e projetos acerca de questões que dizem respeito a suas vidas. "O Programa Fórum Urbano Mundial da Juventude não tem precedentes no que reflete de diversidade, paixão e conhecimento dos jovens de todo o mundo sobre as questões urbanas"', afirma Kevina Power, coordenadora jovem do World Urban Forum Internacional. Portanto, estamos num momento ótimo para que os jovens participem ativamente das discussões de assuntos que afetam as suas vidas.

reach their full potential. In response, UN-HABITAT initiates and fosters inter-agency and partnerships with youth organizations. It engages youth at an international level, to help formulate an international understanding of pressing youth issues. Working with young men and women and understanding their diverse abilities, realities and experiences is an essential element of UN-HABITAT's long term success of achieving sustainable urbanization."

9 "The World Urban Forum youth program is unprecedented in its reflection of the diversity, passion and expertise of youth worldwide on urban issues." 
"Não queremos fazer a revolução.

Queremos fazer revolucionários."

Elmira Nazombe $e^{10}$

\section{A OPÇÃO POR JOVENS}

Não há definição precisa da faixa etária dos aqui chamados 'jovens' porque sua situação, no Brasil e em outros lugares do mundo, é muito diversificada. Os que freqüentam escolas públicas, os que não freqüentam escola nenhuma, os que têm circunstâncias adequadas de educação, possuem condições diferenciadas de desenvolvimento, disponibilidade, interesse e vontade. $\bigcirc$ presente trabalho se refere a todos eles, que se encontrem numa fase da vida em que não têm ainda autonomia financeira, mas sim para circular pela cidade; que estejam no limiar da vida adulta e não sejam mais crianças. $\bigcirc$ foco de interesse deste trabalho são os jovens porque eles "...são parte da solução para as dificuldades que enfrentam, não apenas um problema a ser resolvido por outros" "' Nesse sentido a Universidade tem o papel de contribuir com a educação da população no que diz respeito ao nosso campo de atuação, ou seja, espaços urbanos livres públicos. Crianças e jovens têm um enorme potencial criativo, muita energia, seus conceitos são menos cristalizados que os dos adultos, têm a necessidade e o desejo de serem ouvidos pelo grupo social do qual fazem parte - têm muito a dizer! - e são idealistas; estão na fase de estruturação para a vida adulta. Finalmente, a juventude é uma época de crítica, contestação, reclamação, transgressão, e essas características são um potencial a ser canalizado para a criação e não para a destruição, ou seja, o que tradicionalmente pode ser visto como um problema tem em si uma latência que pode se transformar numa solução. Como exemplo disso pode ser citada a atividade de análise do quarteirão do Colégio Ítaca (ver capítulo 2, pág. 77), quando foi demandado exatamente esse potencial de identificação de problemas; em meio

\footnotetext{
${ }^{10}$ Elmira Nazombe é secretária co-executiva para a Justiça Racial, da Divisão Feminina da ONG United Methodist Women.

11 "...young people are part of the solution to the difficulties they face, not merely a problem to be resolved by others.." - in UNESCO - World Youth Report, $2003 .$.
} 
a um processo bastante tumultuado, essa demanda propiciou uma atividade produtiva, que resultou na busca de soluções para os inúmeros problemas apontados pelos alunos.

Precisamos trabalhar "...a realidade e inseri[r] o aluno no contexto social em que ele vive, buscando no cotidiano os exemplos práticos do processo educativo, e, sobretudo, permitindo aos alunos a construção da história do seu tempo." (SCHIEL, 2002: 19) Não apenas no contexto social, mas também no ambiental. Segundo Adams e Ingham (1998) a participação de jovens em processos de planejamento ambiental traz inúmeros benefícios. "É muito provável que através do envolvimento direto, no futuro os jovens desenvolverão o interesse em questões ambientais, a preocupação com a melhoria das condições ambientais e a motivação em desempenhar um papel ativo na construção de seu ambiente." (ADAMS/INGHAM, 1998, p.34). Projetos para espaços urbanos livres públicos envolvem necessariamente o planejamento ambiental, portanto as seguintes considerações dessas autoras são pertinentes a este trabalho.

- "Idéias e propostas de crianças se estendem e atuam como catalisadoras do envolvimento adulto"; o que significa que ações desenvolvidas com crianças têm um alcance maior do que aquele relativo ao seu envolvimento direto;

- "elas encorajam os adultos à sua volta a contribuir também na mudança ambiental"; ou seja, as crianças atuam como multiplicadoras;

- "pode haver a transferência de técnicas no trabalho com adultos"; o que vem a ser uma troca de conhecimento entre crianças e adultos;

- "quando as crianças aprendem técnicas e habilidades de participação elas as transferem para outras situações e contribuem com o desenvolvimento comunitário"; o aprendizado não se restringe àquela situação, podendo servir a inúmeras outras experiências;

- "quando as crianças se envolvem na formulação e desenvolvimento de idéias para a transformação, a experiência influencia sua percepção do meio ambiente e o significado que tem para si'; e 
esse é um de nossos objetivos - desenvolver a percepção da paisagem, do ambiente em que se vive.

Segundo C. Church ${ }^{12}$ a participação pode agregar valor para a sociedade (através de menos insatisfação, menos vandalismo, etc.) - e reduzir o tempo e o custo de ações de planejamento, lidando com os problemas no estágio inicial de um processo; o envolvimento comunitário pode acelerar o processo, pode fazer com que recursos sejam utilizados mais efetivamente, pode melhorar a qualidade do produto e a sensação de propriedade e pertencimento; pode também aumentar a habilidade e a confiança, e fazendo com que os conflitos podem ser resolvidos com rapidez.

Processos participativos propiciam aos jovens a oportunidade de desenvolverem sua capacidade crítica, bem como habilidades de comunicação e sociais; eles começam a vivenciar o trabalho em equipe, a negociação, a visualização de mudanças e a resolução de conflitos; ganham novos insights e uma compreensão mais profunda dos lugares onde vivem, trabalham e brincam; podem esclarecer seus próprios valores e os de outros; podem pensar em idéias e estratégias para mudanças e melhorias. Todas essa vivências e experimentações têm um enorme potencial para a formação de uma base forte e firme para a participação cidadã ativa nas questões de seu ambiente, seu lugar de vida.

Muitos colocam inúmeros empecilhos à participação de crianças e jovens no planejamento ambiental ou qualquer outra atividade de projeto de área urbana livre pública. Alguns pensam que a infância e a adolescência são períodos sagrados em que as crianças e jovens devem ser protegidas das responsabilidades e problemas do mundo adulto; outros pensam que talvez a participação de crianças e jovens dê uma sensação boa, mas preferem gastar seu tempo, dinheiro e energia em atividades 'mais produtivas'; outros ainda acreditam que crianças e jovens não podem participar por falta de conhecimento, experiência e habilidades; há ainda os que não acreditam que esses atores possam ter algo de importante a dizer, os que

12 In ADAMS \& INGHAM, 1998, p. 35 
acreditam que "dá muito trabalho" e os que aceitam trabalhar com jovens mas mantendo o controle de todo o processo, acreditando não ser possível terem algo a aprender com eles. No entanto, esses argumentos podem ser facilmente rebatidos.

A falta de conhecimento, experiência e habilidades não é justificativa para não se trabalhar com jovens pois é justamente através da experiência que se desenvolvem habilidades e se constrói conhecimento, o que é extremamente produtivo. Quanto a 'ter algo a dizer', todo cidadão têm algo a dizer a respeito de sua vida, e todos têm o direito de dizê-lo e de tê-lo levado em conta. Qualquer trabalho 'dá trabalho'; quando nos propomos a desenvolver qualquer atividade, a excelência deve ser uma meta e isso demanda muito envolvimento, muito tempo, muita dedicação; projetos participativos com jovens não são diferentes. E, como contra-argumento final àqueles que se opõem ao trabalho em parceria com jovens, podemos dizer que temos a aprender com eles, que estão numa fase inicial da vida adulta, cheios de sonhos, ideais, propostas, espírito crítico e energia.

De acordo com Contardo Calligaris, a adolescência é um tempo que a sociedade atual designou como um período de moratória. "Apesar da maturação dos corpos, a autonomia reverenciada por todos como valor supremo, é reprimida, deixada para mais tarde." (CALLIGARIS, p. 17) Ainda segundo o mesmo autor:

"Inicialmente, [o adolescente] é alguém:

- que teve o tempo de assimilar os valores mais banais e mais bem compartilhados na comunidade...;

- cujo corpo chegou à maturação necessária para que ele possa efetiva e eficazmente se consagrar às tarefas que lhe são apontadas por esses valores, competindo de igual para igual com todo mundo;

- $\quad$ para quem, nesse exato momento, a comunidade impõe uma moratória."

Esse período da vida das pessoas não deve ser assim considerado - uma moratória - pois há uma enorme capacidade e talento a serem desenvolvidos pelas pessoas nesse período de vida, que muitas vezes ficam em estado de dormência caso não sejam usados. Sabemos, no entanto, que a definição acima se adequa a 
jovens de classe média e alta, mas não à maioria dos jovens brasileiros. Muitos deles adentram o mundo do trabalho sem no entanto poder continuar freqüentando a escola, e isso quando há postos de trabalho disponíveis. Para esses jovens não há moratória, o que lhes falta é apoio, parceria e confiança da sociedade. Sabemos que a grande maioria dos jovens brasileiros está sem perspectiva, sem sonhos mas, paradoxalmente, a conexão com a realidade é que nos permite sonhar.

A participação de jovens em atividades que dizem respeito a qualquer assunto que afeta suas vidas é mais do que bem vinda - ela é indispensável.

"Em todas as regiões do mundo jovens têm tido que lidar com o desemprego crescente e a insegurança no trabalho, uma grande instabilidade familiar e redução de programas de bem estar social. A juventude é frequentemente caracterizada pela incerteza e pelo risco. São necessárias estratégias efetivas para resolver essas questões. Jovens têm um corpo de experiências específico da sua situação, e têm visões e idéias que derivam dessa experiência. Eles são atores sociais com habilidades e capacidades para trazer soluções construtivas para seus próprios problemas." (ONU, 2003)

Segundo o mesmo documento, os programas com participação de jovens que obtiveram mais sucesso são aqueles que se comprometeram a trabalhar de forma a permitir que suas próprias experiências contribuíssem na busca de soluções para os problemas enfrentados. A participação na forma de questionamentos e apresentação de seus pontos de vista possibilita e contribui não apenas com o desenvolvimento de habilidades e competências, mas também da auto-confiança. $\bigcirc$ real envolvimento acaba com um eventual período de moratória e permite aos jovens a ação efetiva sobre o mundo real, propiciando-lhes então o sonhar com um futuro diferente. Jovens de vários bairros nas periferias das grandes cidades têm demonstrado toda sua inquietação, seus sonhos e revolta, através de inúmeros movimentos de expressão artística - sobretudo musicais, como o rap.

Processos de projeto participativo com jovens podem trazer muitos benefícios a todos os envolvidos, e também muitas contribuições significativas para o projeto em si. "Os processos participativos apresentam-se como uma grande 
oportunidade de dar significado às atividades de projeto e, sobretudo, ao objeto projetado." (GONÇALVES, 2005: 174)

Para que um projeto de espaço livre público seja de boa qualidade ele tem necessariamente que ter a participação de jovens em sua elaboração? Não existe uma resposta, mas podemos dizer que, caso o processo de projeto seja participativo, com a inclusão de jovens (I) há uma grande probabilidade de ele melhor atender às suas necessidades, sonhos e desejos, pois eles terão sido levados em consideração e (2) o processo terá concorrido para a construção da cidadania dos jovens participantes. Além do que, considerando a situação brasileira, de quase total abandono e desrespeito aos espaços livres públicos, a gestão desses espaços têm um potencial muito grande de sucesso caso o projeto daquele lugar tenha contado com a participação de quem vive ali, especialmente jovens e crianças. Isso se daria devido à sensação de pertencimento e de propriedade, à compreensão do que está ali e ao prazer que isso tudo proporciona.

Um processo participativo ocorrido em Santo André, durante a gestão do Prefeito Celso Daniel, que vale a pena ser relatado aqui. Havia uma área da cidade com muitas nascentes, completamente abandonada pelo poder público e cujos moradores solicitaram, junto ao Depav ${ }^{13}$, a ação da prefeitura para a implantação de uma praça no local. Foram muitos meses de trabalho. Os moradores do entorno envolveram-se muito em todo o processo, trabalhando como jardineiros, plantando e cuidando da praça. No entanto, com o tempo, a população não teve condições de garantir a manutenção da praça e a mesma foi se deteriorando. A partir dessa experiência pudemos observar como é indispensável a presença do Estado na gestão dos espaços público. É ele que pode garantir a infra-estrutura, os materiais, as ferramentas necessárias para tal. Outro fator importante é a liderança. Não havia ali liderança forte, além do que, a maioria dos participantes locais do processo era adulta, com mais de 40 anos. Não podemos afirmar qual foi o motivo da interrupção do processo, mas o trabalho de jovens, junto com pessoas de outras idades, tem o potencial de enriquecer e fortalecer o grupo.

${ }^{13}$ Departamento de Parques e Áreas Verdes. 
Pudemos observar, analisando processos participativos, que há muitas vantagens em se trabalhar em parceria com crianças e jovens. Mesmo que os resultados, em função dos objetivos específicos do projeto, não sejam totalmente alcançados, os participantes sempre carregam consigo um aprendizado que pode ser transferido para outras situações de sua vida. Participar daquilo que diz respeito à sua vida parece ser o mínimo a se esperar como direito de qualquer cidadão. É essencial envolver os jovens valorizando suas experiências, suas, vidas, suas opiniões, suas escolhas, sua subjetividade, seus julgamentos e suas críticas..

"Para que os instrumentos previstos no Estatuto da Cidade não se tornem sem uso e sentido é que chamamos a atenção para a necessidade de apropriação da cultura do regime político de democracia participativa pela formação do Cidadão Participativo." ${ }^{14}$ É preciso haver envolvimento dos jovens num processo de fortalecimento da democracia participativa. "...[A]pontamos a necessidade de desenvolver no educando [cidadão] a capacidade de elaborar propostas e preparar argumentos para defendê-las, princípio essencial para a formação da cidadania participativa." 15

É preciso "promover o respeito [pelos jovens] como atores sociais, como agentes em suas próprias vidas, e como cidadãos de suas próprias sociedades". (ONU, 2003) Esse documento aponta a necessidade de se "encorajar a comunidade acadêmica a colaborar com os governos e ONGs lideradas por jovens no sentido de desenvolver indicadores e ferramentas de avaliação, dadas as limitadas capacidades desses últimos grupos nessa área. ...A avaliação é importante, não apenas para fornecer evidências dos resultados positivos [de ações de natureza participativa com jovens] que possam ser demonstradas, mas também para aprendermos mais sobre práticas eficientes e ineficientes, de forma a que os programas possam ser fortalecidos e alinhados."

${ }^{14}$ GONÇALVES, Paulo Cássio de Moraes - "Construção Coletiva da Paisagem", Dissertação de Mestrado defendida na FAUUSP, em dezembro de 2005. (p. 22)

${ }^{15}$ Idem (p. 144) 
Nossa pequena contribuição vem ao encontro dessa demanda de participação da academia, no entanto inclui momentos anteriores: da elaboração de metas e objetivos, e da escolha de metodologia e ferramentas que embasem propostas de projetos participativos com jovens e crianças para que pensem e ajam sobre seus lugares de vida. A avaliação deverá vir num momento posterior e é fundamental para avançarmos no conhecimento desses processos.

Outro aspecto essencial da contribuição da academia em processos dialógicos com a comunidade na busca da construção de conhecimento comum é a capacitação dos adultos (facilitadores, professores, monitores, entre outros) para trabalhos dessa natureza. Buscamos aqui estabelecer algumas diretrizes e nesse sentido o projeto 'I 000 Arquitetos em 1000 Escolas', já citado anteriormente, nos dá um sinal da importância dessa capacitação quando se observa a transformação dos adultos envolvidos no projeto depois de participarem em seminários preparatórios e conversas individuais sobre questões de desenvolvimento, direitos da criança e participação. A transformação, portanto, se deu não apenas nas crianças, mas também nos adultos participantes, que alteraram suas propostas depois dessas atividades.

A transformação dos envolvidos e da sua realidade é um objetivo primordial de qualquer processo participativo.

"A distinção entre um entendimento utilitário ou transformador da participação de jovens e crianças é importante. A abordagem utilitária coloca seu foco nas crianças como recursos, nas contribuições e serviços das crianças, e nas responsabilidades das crianças. Nessa abordagem, a participação das crianças não desafia hierarquias existentes e relações de poder entre adultos e crianças. Elas não têm poder de tomar decisões e os adultos mantêm sua autoridade absoluta.

A abordagem transformadora, por outro lado, considera a participação das crianças como um processo de mudança social na relação entre crianças e adultos. A participação de crianças diz respeito à aquisição de 
maior controle sobre decisões pessoais e públicas. Isto desafia e muda relações de poder existentes entre crianças e adultos." 16

Estas premissas servem para o trabalho conjunto com jovens, para o estabelecimento de uma parceria no sentido de produzir um conhecimento que seja resultado de um diálogo, com tudo que isso tem implícito: conflitos, embates, descobertas, frustrações, conhecimentos e vivências diferentes, habilidades distintas, experiências vivas e criativas.

E podemos contar com eles. Na introdução da Agenda 21 feita por crianças e jovens (ONU, 1994), seus editores dizem, sobre o pedido de governos para as crianças e os jovens se "associarem" a eles na Agenda 21 original:

"Não é a primeira vez, porém: eles a pediram [a associação de crianças e jovens] para a Cúpula Mundial sobre a Infância e para a nova lei sobre os direitos das crianças que 131 países assinaram. Decidimos pegá-los pela palavra! Claro que seremos parceiros, mas parceiros iguais! Somos 28 jovens, muito diferentes entre nós, de 21 países, mas temos algo em comum: estamos cansados - cansados de ver nosso belo planeta poluído, cansados de guerras insensatas, cansados de ver os pobres ficando mais pobres a cada dia, de esperar que os políticos tomem decisões que já deveriam ter tomado muito tempo atrás."

Os jovens desejam ser ouvidos e respeitados, e não usados. "Porque crianças e jovens percebem o mundo de forma diferente dos adultos, sua

16 "The distinction between a utilitarian and a transformative understanding of child and youth participation is important. The utilitarian approach focuses on children as resources, on children's contributions and service, and on children's responsibilities. In this approach, children's participation does not challenge existing hierarchies and power relations between adults and children. Children have no decision-making power and adults maintain their absolute authority.

"The transformational approach, on the other hand, considers children's participation as a process of social change in the relation between children and adults. Children's participation is about children acquiring greater control over personal and public decisions. This challenges and changes existing power relations between children and adults."

in THEIS, Joachim. "Performance, Responsibility and Political Decision-Making: Child and Youth Participation in Southeast Asia, East Asia and the Pacific", Children, Youth and Environments Journal, Vol 17, No.I (2007) ISSN I5462250 (http://www.colorado.eduljournals/cye/I7_I/I7_I_OI_SEAsia_Intro.pdf), acessado em 01/maio/2007 
participação no planejamento, avaliação e execução de projetos é muito importante."17

Vários projetos participativos de espaços públicos com jovens são desenvolvidos pelo Brasil afora, e eles serão tanto mais produtivos, enriquecedores e construtivos quanto mais instâncias institucionais para acolhê-los houverem - algo como conselhos de jovens junto a prefeituras. Isso daria mais estabilidade e continuidade a um processo de participação que realmente influenciasse as ações do Estado. Instâncias formais que acolham jovens na discussão de questões da cidade ainda são incipientes e recentes no Brasil, como o Orçamento Participativo Criança, por exemplo.

“... [A] educação das crianças, jovens e cidadãos em geral não é somente responsabilidade das instituições tradicionais..., mas também deve ser assumida pelo município..." (GADOTTI, 2004: 13) Qualquer passo dado na direção de construir, estabelecer e manter canais institucionais de comunicação entre jovens, a universidade, profissionais e o poder público para o debate acerca de seus lugares de vida é muito valioso.

A prática participativa demora para ser assimilada, aceita, e aplicada de forma rotineira. 'A institucionalização trata da 'inserção' desses novos processos participativos de tomada de decisões para que eles se tornem, para todos os grupos de interesse, a 'maneira' normal 'de se fazer as coisas'..'8 (UN-Habitat, 2003: 98)

E quem é esse jovem de quem estamos falando? Quando nos referimos a jovens, englobamos a pluralidade de condições sociais, psicológicas e físicas, contando com o potencial de todo e qualquer jovem, seja ele de qualquer classe social, de qualquer raça, credo, procedência ou cor, com qualquer que seja sua contribuição, sua participação. Essa é uma condição básica da cidadania, a inclusão

\footnotetext{
17 Idem nota 48 do Cap. I

18 "Institutionalization is all about 'building in' these new participatory decision-making processes so that they become, for all stakeholders, the normal 'way of doing things.'."
} 
de todo e qualquer jovem. Como exemplo dessa posição podemos novamente mencionar o projeto 'I000 Arquitetos em 1000 Escolas', que colocou, numa mesma oficina, crianças com deficiências visuais e de aprendizado, e outras de uma escola privada de vanguarda; juntas elas trabalharam na representação de uma cidade descrita no livro "Cidades Invisíveis", de Ítalo Calvino e o resultado foi a viabilidade de produção conjunta através da troca de saberes.

Como dissemos na introdução deste trabalho, a distribuição de riquezas é desigual no país e no mundo, mas a distribuição de inteligência não - esta é, certamente, igualitária. $\bigcirc$ filme americano "Nascidos em Bordéis", de Ross Kauffman e Zana Briski, de 2004, mostra a realidade de crianças e jovens moradores de Calcutá, na Índia, filhos de mulheres que trabalham como prostitutas, e vivem no Distrito da Luz Vermelha, um dos bairros mais pobres da cidade. Essas crianças, ao serem expostas a situações onde se demanda delas o 'seu olhar', passam a produzir fotografias impressionantes, muito reveladoras da sua condição. Suas produções apresentam tanta qualidade que sensibilizam profissionais da fotografia. Isso nos remete à importância da valorização da inteligência de cada um, e do estímulo, sobre o qual falaremos mais adiante. $\bigcirc$ filme apresenta o poder restaurador $\mathrm{da}$ arte, através da história de crianças que, num certo momento de suas vidas, até então sem sonhos, têm a oportunidade de exercitar sua capacidade de observação e seu potencial criativo e de serem reconhecidos e valorizados por isso pela sociedade. Nesse caso, o agente catalisador foi uma fotógrafa profissional que identificou um enorme potencial a ser estimulado, burilado, desenvolvido e passou a desenvolver um trabalho oferecendo às crianças e jovens material, organização, e estímulo para que elas observassem a paisagem à sua volta e representassem-na através de fotografias. Podemos observar, pela sua produção e através de seus olhares, que esses jovens e crianças, que vivem em condições sociais, econômicas e psicológicas muito precárias e desfavoráveis, têm as mesmas condições e potenciais que quaisquer outros de perceber seu ambiente, criticá-lo e expressar-se a respeito disso. 
"If we are serious about reaching the Millennium Development Goals 19 by 2015 , we must involve young people today. We must invest in them; we must learn from them; we must be their partners"20

Kofi Annan

\section{DEFLAGRANDO O PROCESSO}

Um processo de projeto participativo pode ser iniciado por diferentes atores. A nossa participação, como academia ou como profissionais, pode ser deflagradora ou pode ocorrer a partir de algum convite. Mas a partir do momento em que o processo se inicia, faz-se necessária a identificação dos parceiros iniciais e, conforme dissemos anteriormente, o estabelecimento de um 'acordo' com relação aos objetivos, diretrizes e procedimentos do trabalho, a partir das demandas e expectativas de cada um dos parceiros. Não apenas isso, mas também a explicitação, por todos e para todos, das possíveis contribuições individuais ou de grupo (em função de alguma habilidade, competência, ou simplesmente vontade). Alguns dos possíveis parceiros em processos desse tipo são: a universidade, movimentos sociais, escolas, o terceiro setor (ONGs, OSCIPs, associações) e o Estado, sendo este último um parceiro determinante quando se pretende uma ação transformadora no espaço público, seja ele dentro ou fora de escolas.

${ }^{19}$ As Oito Metas do Milênio (Millennium Development Goals - MDGs) - que vão desde a diminuição pela metade da extrema pobreza até a contenção da expansão do HIVIAIDS e a oferta universal de educação primária, todos até a data limite de 2015 - formam um plano consensual de todos os países do mundo e todas as principais instituições de desenvolvimento. Eles galvanizaram esforços sem precedentes para satisfazer as necessidades dos mais pobres do mundo. São eles: (I ) erradicar a extrema pobreza e a fome; (2) atingir o ensino básico universal; (3) promover a igualdade entre os sexos e a autonomia das mulheres; (4) reduzir a mortalidade infantil; (5) melhorar a saúde materna; (6) combater o HIVIAIDS, a malária e outras doenças; (7) garantir a sustentabilidade ambiental; e (8) estabelecer uma parceria mundial para o desenvolvimento.

20 "Se falamos sério sobre atingir os Objetivos de Desenvolvimento do Milênio até 2015, devemos envolver os jovens hoje. Precisamos investir neles, precisamos aprender com eles, precisamos ser seus parceiros." 
“Criatividade

Desconfiar da observação direta. Um romancista de lápis em punho no meio da vida - esse atento senhor acaba fazendo apenas reportagens.

É melhor esperar que a poeira baixe, que as águas resserenem: deixar tudo à deriva da memória. Porque a memória escolhe, recria.

Quanto ao poeta, que nunca se lembra, inventa.

E fica mais perto da verdadeira realidade."

Mario Quintana

\section{PERCEPÇÃO}

A percepção é o primeiro passo para a compreensão do que se vê, do que se vive. E o olhar é o primeiro sentido utilizado quando se procede à leitura de uma paisagem. ${ }^{21}$ "O ser humano é por natureza um ser criativo. No ato de perceber, ele tenta interpretar e, nesse interpretar, já começa a criar. Não existe um momento de compreensão que não seja ao mesmo tempo criação." (OSTROWER, 1988: 167)

A visão é catalisadora do processo de leitura de uma paisagem. ${ }^{22}$ " $O$ saber é adquirido através da visão; a visão é uma apreensão direta, não mediada de um mundo de objetos transparentes. Dentro desta contextualização, o visível é privilegiado. Ver é a origem do saber. Escrever é reprodução, transmissão - a comunicação do conhecimento adquirido através da experiência (visual, visceral)."23

${ }^{21}$ A percepção não visual no paisagismo é um campo ainda incipiente, mas onde já despontam algumas pesquisas tais como o trabalho de mestrado, na FAU USP, que está sendo desenvolvido sobre percepção de paisagem com deficientes visuais, pela professora Silvia Valentini. artista plástica e professora, sob orientação do professor Euler Sandeville Jr.

22 O filme italiano "Vermelho como o Céu", dirigido por Cristiano Bortone, apresenta uma abordagem educacional com crianças deficientes visuais que caminha no mesmo sentido de nossas propostas, de respeito às habilidades, competências e desejos de cada um para a construção de algo comum.

23 "Knowledge is gained through vision; vision is a direct, unmediated apprehension of a world of transparent objects. In this conceptualization of it, the visible is the privileged; writing is then put at its service. Seeing is the origin of knowing. Writing is reproduction, transmission - the communication of knowledge gained through (visual, visceral) experience." - in SCOTT, Joan W. "Experience", in BUTLER, Judith; SCOTT, Joan W. "Feminists Theorize the Political", New York: Routledge (pp. 22-40), 1992. 
Nossa matéria prima são as paisagens e os jovens que vivem nela; com essa matéria prima propomos uma interação para construir um conhecimento que os habilite, capacite, possibilite, inspire e estimule a agir sobre essa paisagem. Paisagem porque é esse o nosso campo de conhecimento, e jovens por todas as razões expostas anteriormente. E porque são eles que dão vida aos espaços públicos. A paisagem, conforme definida no primeiro capítulo, é a concretude de um lugar, aquela que nossa visão alcança, conformada pela interação entre processos naturais e culturais que contribuem para sua contínua construção. Para que jovens possam atuar nela, interagir com ela, precisam conhecê-la, e para conhecê-la é preciso que entrem em contato com ela. Como arquitetos paisagistas, o reconhecimento dos elementos espaciais e ambientais, da concretude, de uma paisagem é de nossa competência; também o é a trama, das conexões entre esses elementos, como o uso e a ocupação da paisagem, suas relações e organização.

\section{Elementos visíveis}

Os elementos visíveis da paisagem são facilmente elencáveis:

- natureza - corpos d'água, vegetação, relevo, clima;

- $\quad$ edificações/arquitetura - comércio, edificações institucionais (escolas, postos de saúde, centros esportivos, centros culturais), residências (térreas, não térreas);

- $\quad$ espaços livres - praças, parques, outras áreas de lazer, áreas abandonadas, áreas indevidamente apropriadas por moradia e comércio, entre outros;

- $\quad$ caminhos, vias de circulação - ruas, avenidas e outros; vias expressas; vias férreas; rodovias; e

- $\quad$ transportes públicos - ônibus, metrô, trem, barco.

No campo da arquitetura paisagística, propomos, como porta de entrada para o contato com esses elementos, que por si só podem parecer estéreis, a identificação da memória afetiva que os jovens têm como lugar onde vivem, sua relação com ele, as experiências lá vividas, as histórias passadas. Essa relação, que é sempre carregada de alguma emoção, tem o poder de despertar a atenção, a percepção, o reparo e a ligação com o ambiente. É através da identificação individual que cada um percebe sua conexão com a paisagem e pode começar um 
processo de reflexão. A memória afetiva do lugar tem um grande potencial de identidade, de vínculo, o que propicia uma participação mais significativa do jovem em algum processo de leitura daquela paisagem.

Mas estes elementos bio-físicos que compõem uma paisagem urbana são uma fração dela; existe, no entanto, outra dimensão: aquela que denota a forma como a paisagem foi estruturada, construída e as forças que atuam sobre ela, conformando-a.

\section{A Trama}

A organização, o uso e a ocupação dos elementos bio-físicos, as conexões e relações entre eles oferecem-nos informações acerca de como a sociedade se apropria deles; através delas podemos ter pistas sobre qual o tratamento dado aos espaços públicos e privados.

Existe nas cidades uma tensão natural entre natureza e sociedade, e nossa proposta é a utilização do desenho de espaços livres não apenas, mas também, como mediador dessa tensão; o desenho como objeto representante de conflitos e possíveis soluções; o desenho como ferramenta de diálogo entre pares e/ou entre grupos conflitantes; desenho esse utilizado desde a compreensão das paisagens até a proposta para sua transformação. Mas para adentrarmos essa trilha, é preciso mais do que simplesmente a realidade. 
"When I examine myself and my methods of thought,

I come to the conclusion that the gift of fantasy has meant more to me than my talent for absorbing positive knowledge." 24

Albert Einstein

\section{UTOPIA E SONHO}

A utopia e o sonho podem servir como motores da ação. Pensando nisso, um grupo de pessoas que vivem em Toronto, não nascidas lá, mas apaixonadas pela cidade, organizou uma publicação (MCBRIDE, 2005) com idéias, propostas, sonhos, utopias, projeções para a cidade. A idéia surgiu como forma de contribuição no desenvolvimento da cidade. Toda a orla do Lago Ontário, uma área com praias, jardins, piscina e outros espaços públicos, vem sofrendo um processo de ocupação por grandes empreendimentos imobiliários que de certa forma bloqueiam, se não o acesso, ao menos a vista do lugar. A população tem se manifestado contra essa ocupação e um dos artigos da publicação referida acima é um sonho de ocupação diferente para esse área: "Sonho da Orla do Lago". Ele propõe algo impossível, mas com isso traz à tona questões fundamentais para a discussão do assunto. "A melhor coisa que poderia acontecer para a orla certamente seriam cavernas e enseadas. ...E, é claro, cabanas, um pouco deterioradas pelo tempo mas todas alinhadas, da forma que se vê nos filmes. ... Então poderíamos colocar áreas gramadas e áreas com areia nova e... um salão de baile, como o Palais Royale mas a céu aberto... No inverno, seria estéril, e pessoas tristes poderiam caminhar sozinhas... A cidade toda não precisa ser barulhenta e produtiva o ano todo."25 (pp. I12/1 /3) Esse texto, ao mesmo tempo em que é poético, propõe a discussão da necessidade de espaços de lazer, da importância de

\footnotetext{
24 "Quando eu me examino, chego à conclusão que o dom da fantasia significou mais para mim do que meu talento de absorver o conhecimento positivo."

25 "The best thing that could happen to the waterfront would surely be caves and coves. ...And, of course, cabanas, a little weather beaten but all lined up the way you see them in the movies. ... Then we could put in areas of grass and areas of new sand ... and a dance hall, like the existing Palais Royale but open to the sky... In the winter, it would be barren, and sad people could go down alone... The whole city doesn't have to be buzzing and productive year-round."
} 
não fazer com que todos os lugares tenham a mesma feição, entre outros. Esse exercício tem um potencial riquíssimo para processos de projeto, discussão, elaboração e desenho do que se quer para os espaços públicos de nossos lugares de vida.

No projeto "I000 Arquitetos 1000 Escolas" o tema de uma das atividades desenvolvidas pelas crianças foi: Construa Sua Própria Cidade; elas foram estimuladas a trabalhar com diferentes materiais sobre diferentes topografias e terminaram optando por trabalhar com cubos de açúcar: "Nossa cidade de açúcar!" (foto abaixo ${ }^{26}$ )

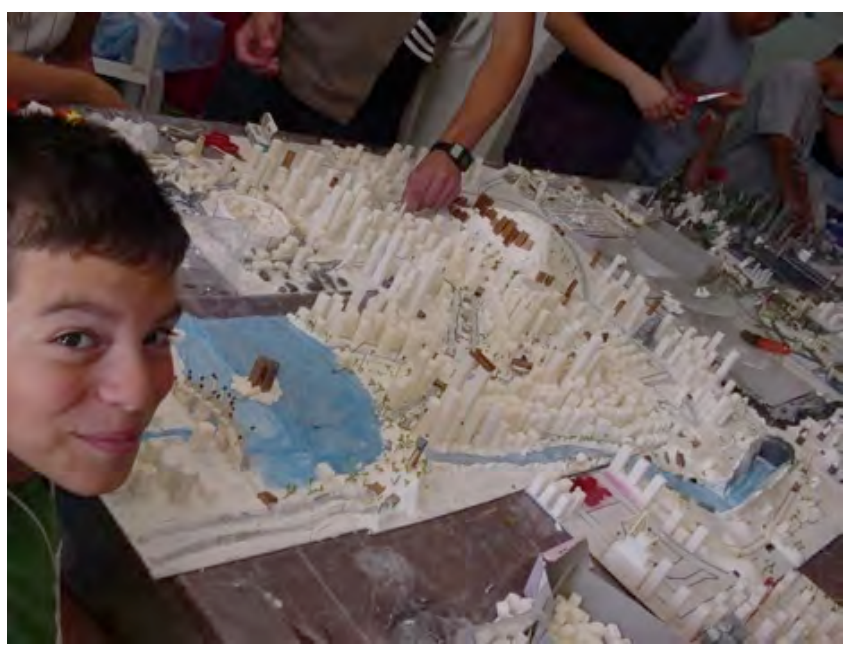

"Se você está buscando a utopia, basta olhar para as crianças. A beleza de se prestar atenção aos jovens é que apesar de não sermos garotos agora, todos nós já o fomos. E carregamos a memória somática daqueles dias em quase todos os encontros surpresa; todos compartilhamos, em algum grau, uma compreensão visceral da impotência [infantil]. ... Excluir um enorme segmento da população - um segmento que está no processo de formação de visões e atitudes que conformarão seu comportamento pelo

${ }^{26}$ Idem nota 48 do Capítulo I. 
resto de suas vidas - é um ato tacanho que só pode servir para limitar nossas próprias possibilidades como adultos."27 (MCBRIDE, 2005: 164)

No documentário "Pro Dia Nascer Feliz", mencionado anteriormente, podemos atestar o desencanto de muitos jovens brasileiros, principalmente das classes mais baixas, mas não exclusivamente, com a falta de perspectivas para suas vidas. Vivemos um momento de fragilidade das relações do espaço público com os atores da sociedade e podemos atestar como esse espaço, essencialmente na periferia das cidades, se apresenta como lugar de cooptação dos jovens para atividades ilícitas e escusas. Esses opções que se lhes apresentam não são as únicas, mas certamente são as de resultado mais imediato. $\bigcirc$ crime e as drogas são um caminho fácil quando não se tem outras escolhas. Temos algo a propor como alternativa a isso? De que forma nosso trabalho pode estimular o sonho desses jovens? Será que pode?

É certo que, para que um jovem que vive na periferia das grandes cidades brasileiras, que é ignorada pelo Estado, não se envolva com o crime, ele e sua família precisam fazer muito mais esforço do que outro que vive num ambiente menos agressivo, menos desesperançoso. Trabalhos participativos como os que estamos propondo são, certamente, uma fração ínfima de tudo que esse jovem necessita, no entanto, talvez seja a parte que nos cabe. Estimular o sonho, provocar a utopia, instigar a curiosidade, atiçar a busca do novo, do diferente, aceitar sugestões de atividades não usuais, deve ser uma das diretivas desses trabalhos. Referências externas à realidade desses jovens são sempre instigantes: histórias de tradição oral ${ }^{28}$, repertório novo, exemplos que possam estimular a reflexão e

27 "If you're searching for utopia, you need to look no further than the kids. The beautiful thing about focusing on youth is that while we may not be kids now, we all were once. And we carry the somatic memory of those days into almost every encounter; we all share, to some degree or other, a visceral understanding of powerlessness. ... Excluding a huge segment of the population - a segment in the midst of forming views and attitudes that shape their behaviour for the rest of their lives - is a narrow-minded act that can only serve to limit our own possibilities as adults."

${ }^{28}$ Não vamos nos ater a esse assunto, mas caso haja interesse, sugerimos as seguintes leituras: MACHADO, Regina - "Acordais", São Paulo: DCL, 2004

SORSY, Inno; MATOS, Gislayne A. - "O Ofício do Contador de Histórias", São Paulo: Martins

YASHINSKY, Dan - "Suddenly they Heard Footsteps: Storytelling for the Twenty-first Century", Toronto: McGilligan Books, 1990. 
estabelecer alguma conexão com situações vividas. E de que forma podemos atuar então?

\section{O MODO DE FAZER}

Formas de trabalho são definidoras e precisam ser sedutoras; para isso, devem ser desafiantes, intrigantes; qualquer proposta feita a jovens e crianças hoje em dia tem, necessariamente, que ter um significado muito forte pois concorrerá com inúmeras outras possibilidades de ação, como a internet, a televisão, o som digital, entre outros, e tudo em um ritmo muito acelerado. Muito se fala sobre importância do respeito ao conhecimento do aluno, da troca de saberes, da vivacidade do trabalho, da relação do tema do projeto com a vida do aluno, mas muitas vezes a prática não corresponde ao discurso. $\bigcirc$ 'como' é uma questão primordial. De que forma devemos atuar para que essas premissas sejam realmente respeitadas? Muitas vezes assistimos a apresentações sobre idéias libertárias da pedagogia, com falas lonas, monótonas, sem a menor preocupação com a aplicação dessas idéias na prática de ensino. Muitas vezes são aulas ou palestras tediosas, que não levam em conta as pessoas a quem o professor ou professora se dirigem. Como atuar de forma que isso não aconteça?

A seguir serão comentados algumas questões relativas a dinâmica, procedimentos, orientação e processo de trabalho, com o intuito de lançar sobre elas algumas luzes, buscando o caminho de práticas libertárias e democráticas. Tais aspectos e enfoques foram destacados em função das considerações feitas sobre as atividades relatadas no capítulo anterior.

\section{Comunicação}

A comunicação num processo participativo é fundamental e isso vale com jovens também, é claro. Uma das bases de um processo como esse é o diálogo, a troca, perseguindo a transformação através dessa interação entre diferentes e pares. Quando estabelecemos uma conversa entre pessoas com bagagens diferentes, vivências diferentes, habilidades diferentes, formações diferentes, o primeiro passo é o estabelecimento de uma linguagem comum. Isso só é possível quando se valoriza 
igualmente cada pessoa, cada grupo envolvido no processo. Havendo profissionais e leigos, haverá necessidade de se encontrar um sistema de troca de idéias, informações, sugestões e propostas que permita que a linguagem técnica e a linguagem leiga, extremamente distintas, e com vocabulário e sintaxe bastante dessemelhantes, possam ser compreendidas por todos. Podemos citar como exemplo o uso de maquetes: elas são mais compreensíveis do que plantas baixas, para quem não costuma lidar com desenho técnico e são ótimas ferramentas de visualização de espaços, podendo inclusive servir como referência para que se desenvolva habilidades de leitura e desenho de mapas, plantas e outras representações de espaço; termos técnicos precisam ser explicados de forma clara e se necessário, substituídos por outros de compreensão coletiva. Da mesma forma, é necessário buscar meios de se compreender a linguagem do cidadão comum, que muitas vezes tem uma forma de expressão bastante diversa da técnica e não sendo por isso menos rico ou mais simples - é simplesmente diferente.

O objeto dos nossos trabalhos é o espaço e o desenho nossa linguagem; o desenho do espaço exige um entendimento que inclui noções como a de escala, de proporção, de representação, entre outras; no entanto, existem inúmeras formas de representação, diferentes das utilizadas por profissionais, para vegetação, construções, vias de circulação; quase tantas quantas são as pessoas. $\bigcirc$ desafio que se apresenta é estabelecer uma linguagem comum, que possa ser compreendida por todos - uma linguagem resultante do diálogo, da troca de saberes - e que sirva aos propósitos do grupo que participa do processo.

"Dogmatists of all kinds - scientific, economic, moral, as well as political - are threatened by the creative freedom of the artist.

For the creative impulse is the speaking of the voice and the expressing of the forms of the preconscious and the unconscious, and this is, by its very nature, a threat to rationality and external control."29

Rollo May

\footnotetext{
${ }^{29}$ Dogmáticos de todos os tipos - científicos, econômicos, morais, bem como políticos - são ameaçados pela liberdade criativa do artista. Pois o impulso criativo é a fala da voz e a expressão das formas do
} 


\section{Arte}

A arte tem uma linguagem acessível a todos por ser "a expressão direta de vivências existenciais que todos nós fazemos de modo semelhante, todos os seres humanos..." (OSTROWER, 1988: 172) De acordo com Chris Cavanagh ${ }^{30}$, qualquer desenho é comunicativo e "[é] isto que o educador popular busca facilitar - a acessibilidade ao espectro completo de meios comunicativos no processo de aprendizagem do participante. Esta acessibilidade não tem a ver com forçar alguém a adotar aquele meio - é, no entanto... prover a oportunidade de seu uso - e, se a oportunidade for agarrada, há a possibilidade de uma ampliação da capacidade do 'aprendiz' de se comunicar e de agir no mundo em seu benefício."31

Em um projeto participativo de leitura e/ou projeto de paisagem, o desenho pode ser uma linguagem que permite a percepção dessa paisagem - desenhar é, antes de mais nada, olhar -, mas também comunicar desejos e sonhos. Atividades que incluam o desenho carecem de esclarecimentos quanto à expectativa que se tem com relação ao produto; precisa ficar claro que a estética não é o ponto fundamental a ser avaliado e sim a capacidade de comunicação; que a intenção não é identificar 'artistas', mas sim oferecer ao grupo mais uma ferramenta de trabalho. Uma das características desse tipo de trabalho é o fato de os desenhos serem um produto a ser compartilhado, e que não deve ser analisado sob o ponto de vista da estética.

O desenho não é, entretanto, a única forma de expressão artística que pode ser usada para a leitura de paisagens ou a representação de sonhos, desejos e

préconsciente e do inconsciente, e isto é, por sua própria natureza, uma ameaça à racionalidade e ao controle externo.

30 professor do curso 'Educação Popular para a Mudança Social' na Faculdade de Estudos Ambientais da York University (Toronto, Canadá)

31 " $[t]$ hat is what the popular educator seeks to facilitate - the accessibility of the full range of communicative means for the participant in learning. This accessibility is not about forcing anyone to adopt that means - it is, however, tendering... the opportunity of it's use - and, should that opportunity be taken, there is the possibility of an increase in the capacity of the learner to communicate and to act in the world for their benefit." in "Do You See What I Mean?" - texto distribuído no curso "Popular Education for Social Change: I Theory and Practice", oferecido no segundo semestre de 2005, na York University, em Toronto. 
propostas. A dança, o teatro, o silk-screen, e tantas outras formas podem servir à comunicação e à significação dessas paisagens, como alternativas às linguagens verbal e visual, predominantes em nossa cultura.

"A arte pode exercer sobre nós poderosos efeitos e, através da imaginação, experimentamos estados que nos encorajam e nos estimulam mais do que nenhum outro estado consciente, terrestre e supraterrestre..."32 A contribuição desse campo de conhecimento é imprescindível para a compreensão da representação elaborada pelos jovens; se não contarmos com ela, corremos o risco de fazer interpretações simplórias, simplistas e/ou incorretas de seus trabalhos. Produções artísticas servem essencialmente como forma de comunicação, e quanto mais opções forem utilizadas, tanto mais possibilidades estarão sendo oferecidas a um grupo de pessoas com habilidades e talentos diferentes.

\section{Estímulos}

Jovens, como já dissemos anteriormente, têm um enorme potencial criativo, de ação, de crítica, de contestação. Quando estimulados, incitados, encorajados, eles despertam a sua capacidade perceptiva, sendo capazes também de criticar, refletir sobre, representar e fazer propostas para uma infinidade de aspectos da paisagem do lugar onde vivem.

$\mathrm{Na}$ atual sociedade brasileira e de tantos outros países com metrópoles como São Paulo, a energia contestadora, crítica, de enfrentamento, de oposição, de refutação de muitos jovens tem canais de expressão muito óbvios em atividades escusas, no mundo das ações ilícitas, pois a estrutura da sociedade não tem continente para ela. Projetos participativos têm o potencial de acolher e canalizar esse potencial crítico e essa energia, que não são poucos, e são muito intensos, para a produção prazerosa de conhecimento, para a visualização de sonhos que podem funcionar como motores da ação e da transformação. Incluir os jovens nesses projetos é respeitá-los, valorizá-los, oferecer-lhes condição cidadã. "Todas as crianças também têm o direito de serem estimuladas pelos adultos na realização de

\footnotetext{
${ }^{32}$ Paul Klee in LAZZARO, G. Di San - "Paul Klee", Lisboa: Editorial Verbo, s/d.
} 
seus esforços. Portanto, professores e pais deveriam observá-las e escutá-las." (GANDINI, 2002: |5I)

Estímulos podem vir em forma de textos e imagens de outros lugares (referências são fundamentais para a criação); pode ser dado com propostas de identificação de situações reais e posterior sugestão de transformação dessas situações em condições de sonho; em forma de propostas de transformação viáveis, factíveis, passíveis de serem executadas; ou ainda na forma de debates sobre temas significativos para esses jovens; e tantas outras. Mais adiante falaremos um pouco mais sobre isso.

As formas de instigar os jovens também são infinitas, mas boas perguntas são sempre bons estímulos; perguntas que os façam pensar, perguntas que os orientem na busca de respostas para suas próprias perguntas. A respeito disso Vera Pallamin faz uma reflexão ${ }^{33}$ contrapondo o pensamento pedagógico tradicional que se baseia na desigualdade entre mestre e aluno partindo da hipótese que o primeiro é detentor do conhecimento e o segundo recebe-lo-á do mestre - ao processo de emancipação intelectual. Segundo a autora, a prática do questionamento com as perguntas: $\bigcirc$ que vês? $\bigcirc$ que pensas disso? $\bigcirc$ que fazes com isso? "não traz em seu bojo nenhuma desautorização da ciência. Ao colocar a igualdade em primeiro plano, ela trata da atitude moral e política fundante na instrução de qualquer coisa a qualquer um. O Mestre Ignorante não é necessariamente 'um professor', mas pode ser qualquer pessoa que exerça este princípio da igualdade das inteligências." O pressuposto de Rancière, cujo livro é discutido no texto de Pallamin, é de que a partir do momento em que se estabelece a igualdade de inteligências, num processo de ensino/aprendizagem, está posta a emancipação. E o papel do professor ou do profissional atuante em processos participativos é sempre estimular os jovens.

\footnotetext{
33 PALLAMIN, Vera - "Ensino e aprendizagem de arquitetura e urbanismo: pensando-se a partir de 'O Mestre Ignorante'. Seminário Ensino / Arquitetura e Urbanismo', FAUUSP, 15 e 16 de maio de 2007.
} 


\section{Organização}

Conforme já foi dito, é essencial que projetos participativos contem com todos os envolvidos desde o seu início, e que seus objetivos sejam claros e acordados entre todos. Um procedimento muito importante para os organizadores das atividades é a preparação dos materiais e do espaço que serão utilizados durante os trabalhos. Essa preparação é fundamental para seu bom andamento. Não importa se seu escopo é restrito ou abrangente, se será apenas um diagnóstico ou se um projeto de paisagismo a ser implantado; o que importa é a garantia de sua conclusão em função dos objetivos e, nesse sentido, a organização é extremamente estruturante. Um projeto pequeno, mas terminado, significa muito mais para as pessoas do que um outro muito extensivo, mas que não pode se completar. Para isso é primordial que sejam discutidos e acordados todos os aspectos do projeto, todas as fases, sua abrangência, sua dimensão, incluindo: a proposta, os objetivos, as justificativas, os procedimentos, as técnicas e ferramentas, a função de cada participante ou grupo de participantes, os registros e a documentação, a avaliação e as possíveis conseqüências, prosseguimentos e decorrências do projeto.

No entanto há que se atentar para uma questão: essa organização não pode ser engessadora, paralisante, inibidora, restritiva. Ela é simplesmente uma linha condutora que deve servir como orientação não podemos esquecer que o improviso é importante e o acaso muitas vezes nos oferece soluções surpreendentes. Especialmente com jovens, que não têm atitudes, idéias, crenças, cristalizadas, deve-se estar sempre atento aos imprevistos, cuidando de perceber quando eles são enriquecedores. Não apenas isso, mas também há que considerar que o planejamento deve ser flexível. Falaremos disso mais adiante. 
Quando perguntado sobre o que faz um bom dançarino, o mestre respondeu:

'Primeiro é preciso conhecer a música tanto quanto a dança.'

'E o que mais?'

'Para ser um dançarino ainda melhor, é preciso compreender as histórias e ser capaz de interpretar seus personagens.'

'Mais alguma coisa?'

'O melhor de todos os dançarinos é aquele que faz tudo o que eu disse e é fazendeiro.'

Provérbio javanês

\section{Interdisciplinaridade}

Os jovens do século $X X \mid$ são multimídia, têm um trato muito bom com simultaneidade e lidam com veemente intimidade com a internet, ferramenta que possibilita o trânsito fácil e intenso pelos caminhos entrecruzados de vários campos do conhecimento, vários países, várias línguas, vários sites, várias enciclopédias, vários blogs - eles são seres interdisciplinares.

"O campo do paisagismo é, por sua própria natureza, interdisciplinar.

Desde sempre foi preciso entender os ciclos biológicos e as vicissitudes dos reinos vegetal e animal, lidar tecnicamente com materiais inertes, captar as demandas do cliente (seja um individuo, grupo social e até a sociedade como um todo), para dar respostas esteticamente satisfatórias, que preencham expectativas em projetos, e compreendam ainda custos e planejamento de execução e manutenção. A paisagem, como síntese formal e estética das relações entre a sociedade e seu meio biofísico, sugere um campo abrangente de trabalho. Esse campo tem se complexificado na medida da evolução das sociedades e da própria expansão do quadro de variáveis (cada vez mais diversificadas) que adentram sua episteme." (LIMA, 2006: 78)

Acreditamos que, se não por outro motivo, pela riqueza de enfoques e de objetos, o paisagismo é um campo riquíssimo e fecundo para projetos participativos de espaços públicos com jovens. A educação ambiental, disciplina muito próxima do paisagismo, e que tem muitas contribuições a dar na leitura de paisagens e em propostas para sua transformação, tem o mesmo caráter interdisciplicinar. Essa 
característica pode ser um fator bastante atrativo, e colaborar, com a perspectiva de desafio para o encantamento dos jovens.

\section{Processo/continuidade}

A prática aqui proposta, como vimos, é recente, precisa ser descoberta, desvendada, desenvolvida, praticada, avaliada, repensada; têm sido definidas algumas diretrizes para essa prática e é certo que os processos devem ser contínuos, pois fazem parte de um aprendizado permanente, que se desenrola ao longo do tempo, e não deve parar. "O produto não é o fim do processo. Ele deve ser administrado, reavaliado e adaptado às necessidades cambiantes. Aqueles mais diretamente envolvidos com o produto... são os mais capacitados a assumir tais tarefas." 34 (SANOFF, 1990: 20)

Os passos são pequenos e não são dados todos na mesma direção; a construção do caminho se dá pela complementação, pelo cruzamento, pelo convívio, pelo diálogo entre diferentes atores e projetos. Não esquecendo que a proposta de projetos participativos visa à construção da cidadania, temos que considerar que um só projeto não é suficiente para essa tarefa; são necessárias diferentes abordagens, diferentes exercícios, diferentes práticas, diferentes vivências; e elas precisam se desenrolar ao longo do tempo, contribuindo e permitindo a construção de conhecimento, de autonomia, de emancipação. "Trata-se de um movimento sem fim - tanto para professores quanto para alunos - e que se depara continuamente com novos atritos e rugosidades, ligados a situações e enfrentamentos cada vez mais complexos." 35

"Nem todos os projetos e oportunidades permitirão o mesmo tipo ou grau de envolvimento. Crianças não podem ser subitamente envolvidas de formas que demandam altos níveis de habilidades, sem ter tido outras oportunidades de adquirir experiência e desenvolver algum grau de

\footnotetext{
34 "The product is not the end of the process. It must be managed, reevaluated and adapted to changing needs. Those most directly involved with the product, the users, are best able to assume those tasks."

35 Idem nota 33.
} 
confiança e competência. Portanto, o que se aprende com uma

experiência pode ser reinvestido em envolvimentos subseqüentes. $\bigcirc$

efeito é cumulativo e de longo prazo." ${ }^{36}$ (ADAMS, 1998, p. 31)

"... a habilidade das crianças em participar... se desenvolve

gradualmente." ${ }^{37}$

\section{Liderança}

É indispensável a existência de uma liderança que seja a locomotiva do processo. Pudemos observar isso em algumas experiências: no projeto do Parque Pinheirinho d'Água, que contou, em certos momentos, com lideranças de movimentos de moradia, em outros com a professora Márcia da Penha Rezende, que coordenou as atividades de seus alunos e foi figura essencial no diálogo entre eles e os professores e alunos da pós-graduação, e o poder público; e na praça em frente a um colégio, onde a diretoria da escola cumpriu esse papel. Ao mesmo tempo, observamos como a falta de liderança contribuiu com o fracasso do trabalho na Escola Alberto Torres (os três processos foram descritos no capítulo 2).

"Eu nunca pratico; eu sempre brinco."

Wanda Landowska ${ }^{38}$

\section{Prazer e paixão}

Segundo Hanna Arendt a participação nos assuntos humanos, o agir político, constitui uma atividade prazerosa: o gozo e a alegria que acompanham todo começo, toda experimentação. "O amor mundi é precisamente o deleite que se sente na ação política, essa vontade de agir como 'o prazer que irresistivelmente

\footnotetext{
36 "Not all projects and opportunities will permit the same kind or same degree of involvement. Children cannot suddenly be involved in ways which demand high levels of skill, without having had other opportunities to gain experience and develop some measure of confidence and competence. Therefore what is learned from one experience may be reinvested in subsequent involvement. The effect is cumulative and long term."

${ }^{37}$ Roger Hart, in ADAMS \& INGHAM - "... children's ability to participate... develops gradually."

38 Música, musicóloga e cravista polonesa.
} 
produz a faculdade humana de começar de novo, a alegria que deve acompanhar todo o novo quando brota para a prosperidade'." (ORTEGA, 2000: 40) O prazer que permeia qualquer ação é, para os jovens, bem como para qualquer ser humano, um sentimento que alimenta, estimula, acalma, energiza e fortalece. A transformação de si mesmo ou da realidade em direção ao que se almeja é sempre jubilosa. $\bigcirc$ que, aliás, não exclui o simples prazer como valor em si, como jogo e brincadeira.

\section{"Deslumbrante}

A beija-flor estava se exibindo tanto, fazendo a luz vibrar a partir da ponta de suas asas, cantando de maneira tão óbvia e flagrante para si mesmo, que a pata franziu a a testa. A beija-flor a ignorou; ela estava executando uma cambalhota totalmente desnecessária. A pata falou: 'Você não deve ficar fazendo esse alarido e voando dessa maneira'. A beija-flor se espantou. Parou no meio do vôo e deu uma pirueta. A pata estremeceu - mais exibicionismo. 'Por que não? É muito divertido. Venha e experimente você também.' A pata parecia mais e mais irritada. 'Você estraga a atmosfera.' A beija-flor agora se balançava para cima e para baixo na ponta de um galho. 'O que, voando?' Subitamente ela disparou pelo ar, bem para o alto. A pata se sentiu tranqüilizada - ela havia espantado o incômodo; quando subitamente a beijaflor passou zunindo por ela. 'Você é uma dor de cabeça hiper-ativa!' gritou a pata. 'Por que? O que estou fazendo de errado?' A beija-flor se balançava numa trepadeira. 'Você ocupa espaço.' Murmurou a pata. 'Não tanto quanto você' retrucou a beija-flor. A pata perdeu o controle. Batendo as asas fortemente, investiu contra a beija-flor, que se esquivou. A pata a perseguiu. Finalmente, quando a pata estava certa que a beija-flor havia ido embora, acomodou-se para tomar sol. Três segundos depois ela ouviu a beija-flor dizendo, 'Eu te falei que era divertido. Agora sou eu que te persigo e você foge.' 
Pergunta: se você fosse uma pata, o que faria? Praticaria a paciência, se mudaria, iniciaria uma campanha para tornar beija-flores ilegais, pediria à beija-flor algumas aulas de vôo? $?^{39}$

Jovens que podem estar presentes e atuantes quando se está discutindo assuntos que afetam direta ou indiretamente suas vidas, dando início à busca de suas aspirações, terão prazer em ter suas vozes ouvidas. E se as atividades envolvidas nesse processo forem prazerosas, tanto melhor.

"Diálogo familiar - Mas por que você não escreve umas coisas mais sérias? - Ora, tia Élida! Eu já não sou mais criança..."

Mario Quintana

\section{Responsabilidade e pertencimento}

A gestão dos espaços públicos deve sempre contar com a participação da comunidade, pois dessa maneira ela se responsabiliza por eles, criando um sentimento de pertencimento e de propriedade coletiva, resultando daí uma relação produtiva, cuidadosa, afetiva, amorosa, que só faz melhorar a qualidade dos espaços e de sua relação com eles. Retomando a questão da juventude como um período em que muitas vezes os jovens são tratados como 'ainda não responsáveis', vivendo, como diz Contardo Calligaris, um período de moratória, podemos dizer

39 "The sunbird was showing off to such a degree, making the light vibrate off her wingtips, obviously and blatantly singing to herself, that the duck frowned. The sunbird ignored her, she was executing a wholly unnecessary somersault. The duck spoke: 'You ought not to racket and rocket about in quite that manner.' The sunbird was astonished. She stopped in mid-flight and reversed herself. The duck winced - more showing off. 'Why not? It's great fun. Come and try it yourself.' 'You spoil the atmosphere.' The duck was sounding more and more cross. The sunbird by now was bouncing up and down on the end of a twig. 'What, by flying in it? Suddenly she shot high into the air. The duck felt pacified - she had driven away the nuisance, when the sunbird whizzed past. 'You're a hyperactive headache!' the duck shouted. 'Why? What do I do wrong?' The sunbird was swinging from a nearby creeper. 'You occupy space,' muttered the duck. 'Not as much as you,' retorted the sunbird. The duck lost her temper. With a great flapping of wings she rushed at the sunbird. The sunbird dodged. The duck chased her. At last when the duck was certain that the sunbird had gone, she settled down again to sun herself. Three seconds later she heard the sunbird saying, 'I told you it was fun. Now I'll chase you and you dodge. Question: if you were a duck, what would you do: practice patience, move, start a campaign to make sunbirds illegal, ask the sunbird for flying lessons?" "Dazzler", in NAMJOSHI, Suniti "The Blue Donkey Fables", London: The Women's Press, 1988. 
que participar da gestão de espaços públicos oferece aos jovens a oportunidade de, em parceria com adultos, crianças, e outros grupos, exercitar de forma efetiva suas capacidades e habilidades, em atividades que não são de 'faz-de-conta'.

"We're here to persuade each other!"

Chris Cavanagh

\section{Superação de conflitos}

As cidades brasileiras têm uma diversidade enorme de interesses, de etnias, de classes sociais, de grupos econômicos, de simpatias partidárias, de crenças religiosas, entre outros. Quando falamos em projetos participativos, é indispensável se pensar em resolução de conflitos e essa não é uma habilidade a qual se nasce sabendo - é necessário praticar. Os espaços públicos são de todos e, para que se chegue a algum consenso a respeito de qualquer ação sobre ele, é preciso que haja diálogo e, quando houver algum impasse, a negociação. Esse é um exercício que faz pensar, faz com que se relacione prós e contras, faz com que se avalie diferentes possibilidades e, eventualmente, faz com que algum interesse ceda espaço a outro. Não somos ingênuos a ponto de acreditar que grupos econômica ou politicamente poderosos tenham interesse em negociar com a comunidade, no entanto, práticas participativas contínuas podem fortalecer e capacitar grupos menos poderosos para negociações difíceis.

No Parque Dufferin Grove ${ }^{41}$, mencionado no capítulo anterior, a negociação da comunidade com o poder público possibilitou a implementação de atividades comunitárias muito freqüentadas como pizza no parque, sopa no parque, e a construção de um espaço para crianças feito de adobe e mosaicos. Algumas moradores do bairro iniciaram atividades que envolviam o preparo de alimentos e foram proibidas pela prefeitura de continuá-las por motivos de insegurança sanitária; houve resistência dessa comunidade, que buscou o diálogo e depois de alguma

\footnotetext{
40 "Estamos aqui para persuadir-mo-nos uns aos outros!"

${ }^{41}$ http://dufferinpark.ca/home/wiki/wiki.php
} 
negociação, conseguiu-se que a prefeitura se responsabilizasse pelo forno, e providenciasse instalações adequadas para as atividades, como o fornecimento de água quente e fria, por exemplo. Hoje elas são feitas em parceria.

\section{Grandes miudezas}

A população urbana brasileira é muito grande; qualquer evento interessante que se proponha reúne rapidamente cem, duzentas, quinhentas, mil ou mais pessoas. Jovens vivem um momento de suas vidas onde necessitam de atenção, de orientação, de diretrizes, de guias, de modelos. Em situações de massa, de grupos muito grande de pessoas não existe a possibilidade da aproximação necessária para esse atendimento. Os projetos propostos aqui são de pequena escala; é preciso poder escutar o sonho de cada um, a desilusão de cada um, a sugestão de cada um, a crítica de cada um. Só assim a participação será significativa e construtiva.

Mas a importância da pequena escala não se restringe ao número de participantes do processo. Os seus objetivos, caso sejam também pequenos e simples, têm maior chance de ser alcançados. A clareza de objetivos facilita o percurso da trilha na busca de sua consecução. Mesmo que o objetivo seja ambicioso, é bastante produtivo esmiuçá-lo de forma a deslindar cada um de seus passos, para que se possa ter satisfação com cada etapa alcançada.

Em Essaouira, no Marrocos, por exemplo, foi desenvolvido, pelo UNHabitat, um trabalho de planejamento urbano estratégico, no âmbito da localização da Agenda 21. O contexto geral no Marrocos é limitado e não favorável ao envolvimento da sociedade em discussões que dizem respeito à cidade. Por isso considerou-se que a "...organização de atividades para associações, a criação de espaço institucional de debates para essas associações e a provisão de equipamentos para essas atividades podem ser considerados passos importantes." (LOECKS, 2004: 208) Por isso, o contexto é de suma importância para que se faça a avaliação correta do processo. 


\section{METODOLOGIAS/TÉCNICAS/FERRAMENTAS}

\section{Estudos do meio}

Segundo Tsoukala, que desenvolveu uma pesquisa sobre a imagem da cidade na criança, na imagem 'subjetiva' "a cidade se identifica com o espaço pessoal da criança - à sua vizinhança - ou ainda a um espaço imaginário, mesclando elementos do seu bairro a elementos de outros bairros ou compondo elementos que refletem a idéia da cidade em geral e não particularmente da cidade de Tessalônica." 42 (TSOUKALA, 200 I: 156) Na "imagem 'objetiva', inversamente, a cidade e seu centro aparecem na maioria dos desenhos. "Um fator que influencia a construção desta imagem da cidade é a atividade da criança em seu espaço. $\bigcirc$ uso de parcelas do espaço pelas crianças determina a escolha que se faz ao nível mental em vista da passagem da concepção à representação topográfica desse espaço." O que almejamos é que os jovens tenham domínio sobre seus lugares de vida e sua cidade. Para tanto, devemos colaborar com nossos conhecimentos e nossa prática profissionais. Quanto mais atividades em espaços públicos, maior a sua compreensão a respeito deles. Portanto, o estudo do meio é uma metodologia mais do que adequada aos nossos objetivos. Através dele os jovens aprofundam seu conhecimento acerca da cidade, de seu bairro. Diz ainda Tsoukala (p. 157): "As crianças que exploram o espaço junto com outras crianças de sua idade desenham mapas mais complicados do que as que se movimentam no mesmo espaço utilizando-o como base material de suas atividades e não como objeto de suas atividades." Isso fica bastante claro no trabalho feito no Colégio Ítaca, onde os mapas de percurso feitos pelos adolescentes que vão sozinhos à escola, se utilizam de ônibus, ou andam à pé, são mais ricos de detalhes que os outros, que são levados de automóvel. Voltando a Tsoukala, "[s]egundo Vigotsky, o espaço urbano oferece estímulos-informações sobre a evolução histórica e cultural, sobre as práticas sociais, os sistemas de valores e os modelos de comportamento." Mas isso

\footnotetext{
${ }^{42}$ Tessalônica é a segunda maior cidade grega, com I,5 milhão de habitantes.
} 
não se dá de forma passiva. Esses estímulos-informações são transmitidos através de atividades interativas no espaço.

“...não nos esqueçamos de que a paisagem também se define por uma exigência estética, que não é nem luxo nem desperdício, mas uma necessidade absoluta para a vida humana e sem a qual a própria civilização perderia sua razão de ser."

Roberto Burle Marx

\section{Representação}

A representação de uma paisagem é uma das formas de se procurar compreendê-la. $\bigcirc$ campo do paisagismo tem algumas contribuições a oferecer para esse trabalho. A confecção de maquetes, modelos 3-D, mapas (de vegetação, de relevo, de vias de circulação, de uso e ocupação, de corpos d'água, e tantos outros elementos que compõem uma paisagem), fotos aéreas, desenhos de observação, desenhos da cidade como um todo, desenhos de percursos (casa/escola/casa, compras, passeios, visitas a familiares e/ou amigos), desenhos de observação de lugares significativos, desenhos de memória, fotos e projetos são algumas das ferramentas utilizadas nessa representação e que contemplam não apenas registros, diagnósticos, mas também possibilitam o sonho, a projeção do futuro, a expressão de desejos e necessidades.

\section{Possibilidades}

Existem inúmeras outras atividades e ferramentas que podem ser utilizados em projetos participativos com jovens. A iniciativa Growing Up in Cities, mencionada no segundo capítulo, nos fornece a sistematização de algumas possibilidades de trabalho. Sua base metodológica de ação se compõe de algumas atividades que caminham no sentido de capacitar crianças e jovens para o diagnóstico e a elaboração de propostas para seus lugares de vida e a idéia principal é que o processo dever ser necessariamente participativo. $\bigcirc$ livro "Making Better Cities with Children and Youth" (DRISKELL, 2002), é como um manual de projeto e propõe atividades, tendo como fundamento a pesquisa-ação. Vamos apenas listá-las abaixo e para melhor compreensão, deve-se consultar o livro. 
- Fotografia

- Passeios guiados por crianças e/ou jovens

- Entrevistas

- Com jovens participantes

- Com moradores do bairro

- Teatro, jogo de papéis

- Teatro de bonecos

- Mapas

- mapas de uso do espaço

- análise sobre o mapa, de uma caminhada guiada

- Discussão em pequenos grupos (grupos focais)

- $\quad$ Estudo de outro local para comparação com o pesquisado

- Hanging out ${ }^{43}$

\section{Documentação}

A documentação dos processos participativos com jovens é de grande valia, pois ela exerce a função de sistematizar e registrar a memória do trabalho, permitindo sua visualização, apropriação e conseqüente avaliação para possíveis ações subseqüentes; todos os desenhos, fotos, entrevistas, histórias, mapas, relatórios, levantamentos, são material com enorme potencial. Como frisamos anteriormente, os jovens hoje não apenas têm uma multiplicidade de acessos a informações, como também têm uma habilidade enorme em lidar com diferentes mídias, com a rapidez que caracteriza a época atual, e com a concomitância de ações. Registros como um mural; um diário; fotos, desenhos, colagens, bordados e outros; uma coleção de sementes, folhas, pedras; e tantas outras opções, são importantes referências para a reflexão sobre o processo; eles têm a primordial função de socializar as conquistas do grupo e também de permitir que se retome qualquer etapa dos trabalhos para posterior continuidade e/ou avaliação.

\footnotetext{
43 a expressão 'to hang out' não tem correspondente no português; ela significa algo como 'ficar na rua com amigos'.
} 
Como decorrência desses registros pode-se produzir uma infinidade de produtos: exposições sobre o bairro, um jornal do bairro, painéis que apresentem situações e condições dos espaços públicos locais, cartões postais, revistas, mapas ou guias do bairro, o projeto de uma praça, ou do espaço livre da escola - essa lista é interminável. Abaixo, uma esquematização de processos de documentação que mostra como ela é ferramenta fundamental para a avaliação e o planejamento.

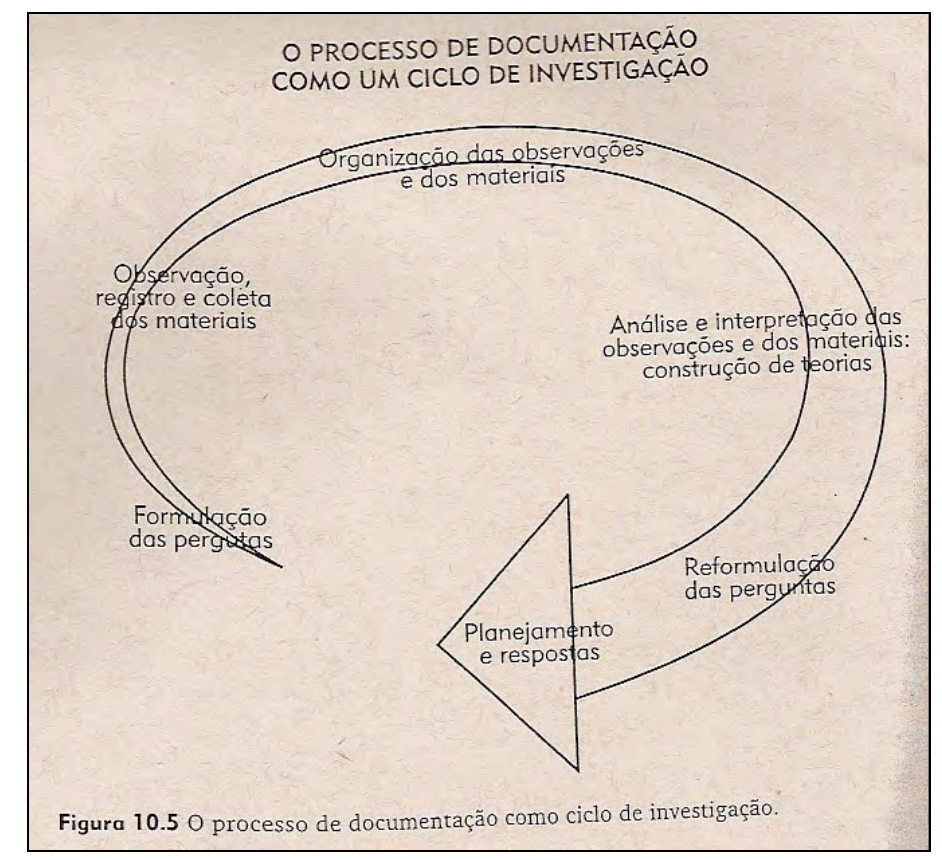

(GANDINI, 2002: 162)

\section{AVALIAÇÃO}

O sucesso de um projeto tem aspectos intangíveis e difíceis de se avaliar, que são as mudanças na percepção e nas atitudes dos jovens. A avaliação de qualquer processo de projeto participativo é muito importante, e sua documentação fundamental para a construção de um aprendizado. Como todas as outras etapas de práticas participativas, esta também o deve ser. "A documentação, interpretada e reinterpretada junto com outros educadores e crianças, oferece a opção de esboçar roteiros de ação que não são construídos arbitrariamente, mas que respeitam e levam em consideração todas as pessoas envolvidas." (GANDINI, 2002: 150) Essa autora discute o papel e a importância da documentação em processos de educação infantil, e muitas de suas idéias são pertinentes também aa educação de jovens. A documentação, feita ao longo dos processos, permite que se 
reflita sobre eles e oferece a oportunidade de flexibilização do planejamento, através da ponderação contínua a respeito das ações, exercícios e atividades desenvolvidas.

A avaliação individual também é um instrumento importante, permitindo que cada um reflita sobre o processo sob outro ponto de vista - o seu próprio e único -, .podendo ser compartilhada com o grupo ou não; assinada ou não.

"Seria um exagero defender que esses projetos mudaram o status das crianças na Turquia e causaram transformação social. Entretanto, só fazer com que arquitetos começassem a olhar para o mundo de uma outra perspectiva, pode ser considerado um grande passo." 44 Essa avaliação do projeto 'I 000 Arquitetos em 1000 Escolas' vem ao encontro de nossa proposição a respeito da importância da continuidade dos processos de construção da cidadania, e da noção de que ele é longo e deve ser desenhado, pavimentado e percorrido passo a passo.Existe uma outra instância de avaliação que tem condições de ser implementada, mas precisa ainda ser discutida: a avaliação feita algum tempo depois da finalização do processo. Os objetivos primeiros de práticas participativas com jovens na paisagem são a construção da cidadania, o despertar da consciência com relação ao ambiente em que vivem, a capacitação para a discussão a respeito disso. Nesse sentido, seria bastante enriquecedor para as reflexões acerca do planejamento de projetos futuros, a verificação da mudança ou não de atitudes dos jovens participantes de projetos completados há algum tempo.

Abaixo, uma tentativa de organização de perguntas que poderão nos fornecer pistas e informações, caso sejam feitas depois de algum tempo de findo o processo.

I. Você se lembra da atividade da qual participou em

2. Quais os aspectos positivos dos quais você se lembra?

3. Quais os aspectos negativos dos quais você se lembra?

\footnotetext{
44 "It would be an overstatement to claim these projects have changed the status of children in Turkish society and have caused social change. However, just getting architects to start looking at the world from another perspective can be considered a big step." - Idem nota 48 do Cap.I
} 
4. Você se lembra de quem coordenou as atividades?

5. Você se lembra de quem participou das atividades com você?

6. Você aprendeu algo com aquelas atividades?

7. Em caso positivo, o que?

8. Esse aprendizado contribui, alterou a sua prática?

9. Alterou sua visão de mundo?

10. Você participou de mais algum projeto dessa natureza, desde então?

I I. Você acha que valeu a pena participar?

12. Você participaria novamente de um grupo de trabalho semelhante?

13. Por que? Para que?

14. Você poderia pensar em alguma expectativa sua, em algo que gostaria de trabalhar, discutir, pensar, fazer, caso tivesse a oportunidade de participar de alguma atividade similar, hoje?

Isso levanta algumas questões, tais como: 'Quanto tempo depois se deve fazer essa investigação?', 'Como encontrar os jovens que participaram do processo a ser avaliado?', "É pertinente manter algum vínculo como eles para contato futuro, tendo em vista a avaliação a posteriori?', 'Existe alguma maneira de avaliar se e quais objetivos foram alcançados?, 'Qual?' Esse é um campo que ainda demanda investigação, e é de suma importância para a construção de conhecimento sobre os efeitos de processos participativos na paisagem com jovens. 


\section{UMA PROVOCAÇÃO}

"Be passionately aware that you could be completely wrong"

Chris Cavanagh

Estamos num certo lugar, num certo momento histórico, temos certos princípios, certas crenças, em meio a uma certa sociedade, que por sua vez é regida por um certo sistema. Mas será que estamos certos?

"Pode ser que não haja outra forma de se educar pessoas. Possivelmente, mas eu não acredito nisso. Por enquanto, ajudaria pelo menos descrever as coisas de maneira apropriada, chamá-las pelos seus nomes corretos. Idealmente, o que deveria ser dito a todas as crianças, repetidamente, ao longo de sua vida escolar é algo como o que segue:

Você está no processo de ser doutrinado. Nós ainda não desenvolvemos um sistema educacional que não seja de doutrinação. Desculpe, mas isso é o melhor que podemos fazer. O que estamos the ensinando é um amálgama de preconceitos da época atual e escolhas desta cultura em particular. A mais ligeira olhadela na história mostrará o quão impermanentes essas coisas devem ser. Vocês estão sendo ensinados por pessoas que deram conta de se acomodar a um regime estabelecido por seus antecessores. É um sistema auto-perpetuador. Aqueles de vocês que são mais robustos e singulares que outros, serão encorajados a partir e encontrar maneiras de se auto-educar - educando sua própria opinião. Aqueles que ficarem devem lembrar, sempre e a todo momento, que

45 "Esteja entusiasticamente ciente de que você pode estar completamente errado." 
estão sendo moldados e padronizados para se encaixar nas necessidades

estreitas e particulares desta sociedade em particular." ${ }^{46}$

46 "It may be that there is no other way of educating people. Possibly, but I don't believe it. In the meantime it would be a help at least to describe things properly, to call things by their right names. Ideally, what should be said to every child, repeatedly, throughout his or her school life is something like this:

'You are in the process of being indoctrinated. We have not yet evolved a system of education that is not a system of indoctrination. We are sorry, but it is the best we can do. What you are being taught here is an amalgam of current prejudice and the choices of this particular culture. The slightest look at history will show how impermanent these must be. You are being taught by people who have been able to accommodate themselves to a regime of thought laid down by their predecessors. It is a self-perpetuating system. Those of you who are more robust and individual than others, will be encouraged to leave and find ways of educating yourself - educating your own judgment. Those that stay must remember, always and all the time, that they are being molded and patterned to fit into the narrow and particular needs of this particular society."' - in LESSING, Doris - "The Golden Notebook", NY: Harper, 1999. 
CONSIDERAÇÕES FINAIS 
"É em bando que o passarinho cantando desperta o sol."

Poeta popular, de Itajubál

caminho percorrido neste trabalho esclareceu algumas questões relativas ao tema estudado e, ao mesmo, tempo apontou possibilidades de aprofundamento de outras tantas. A paisagem, objeto de estudo da arquitetura paisagística, carrega em si uma infinidade de significados, histórias e segredos. $\bigcirc$ desafio colocado foi pensar em formas de encantamento, de estímulo, de incitamento à ação que o ambiente pode proporcionar aos jovens, assim como o fazem os esportes radicais, as 'baladas', as greves, o skate, as turmas de amigos e outros. Vivemos hoje tempos de inquietude, tempestades e borrascas, em que muitos desafios se apresentam. Para que sejamos capazes de avançar de forma segura em um caminho que leve a alguma calmaria ou algum porto seguro, ao menos até a próxima tempestade, é preciso compreender os ventos, as correntes e outras forças que nos estejam transportando.

Nós, cidadãos brasileiros, somos crianças, jovens e velhos. Somos brancos, negros, amarelos, vermelhos - somos multicoloridos. Somos brasileiros, italianos, pernambucanos, alemães, baianos, potiguares, amazonenses, japoneses, paranaenses. Gostamos de baião, Beethoven, rock, MPB, rap e jazz. Somos homens e mulheres. Para que essa enorme equipe possa desempenhar como uma boa tripulação, todos têm que estar presentes, todos devem participar, todos têm o direito de ser ouvidos, atendidos, considerados.

A opção por jovens é a escolha de um segmento da população brasileira que tem muito a dizer e a quem ainda são poucos os que escutam, apesar de já

\footnotetext{
I In MACHADO, Regina - "Acordais", São Paulo: DCL, 2004.
} 
estarem ocorrendo aqui um grande número de eventos que buscam reunir jovens protagonistas para debates, avaliações e trocas de experiência - apenas em 2005 ocorreram os seguintes eventos: $8^{\circ}$ Encontro Nacional de Adolescentes, Rio Claro/SP; Festival Nacional da Juventude, Brasilia/DF; Festival $\bigcirc$ Adolescente e a Arte pelos Direitos Humanos, Salvador, BA; V Encontro Nacional de Meninos e Meninas de Rua, Brasilia/DF; Seminário Vem Ser Cidadão, Faxinal do Céu/Paraná.

Novos campos de investigação se abrem ao término desta jornada e, no âmbito de cada um deles, inúmeros aspectos ainda precisam ser enfrentados. Pesquisas que possam avançar, fornecer novas perspectivas, averiguações sobre formas de procedimento, de avaliação, de conteúdo pertinente. São portas que se abrem para que se possa, num futuro próximo, abrir um espaço generoso - no sentido de amplitude e de caráter - onde nossos jovens sejam acolhidos e tenham a possibilidade de se envolver e desenvolver com a paisagem de seus lugares de vida.

Aliás, eles já estão percebendo . . .

\section{O RAP DO MAR}

"Muitas pessoas jogam lixo no mar,

Com isso não poderemos mais pescar

E ficaremos doentes

Se lá formos nadar;

Os peixes não poderão mais respirar

Autoridades,

Vim aqui para me queixar:

Toda essa poluição tem que acabar;

Senão essa beleza pouco vai durar

E a paz não vai mais lá reinar.

A situação é de desesperar,

Tomem cuidado, ou mar vai acabar."

Dominique Sttanffer, II anos, São Paulo, Brasil

2 In UNICEF, 1994: 23 


\section{... sonhando... \\ O PEQUENO JARDIM}

"Buzinas estridentes e uma pressa maluca foi tudo o que sobrou em minha vida depois de mudar para o apartamento de quinto andar na cidade. Minhas paixões foram completamente esquecidas. Meu amor pelas plantas morreu. Ate o dia em que uma onda cerebral me atingiu. Eu esbocei um plano e listei as coisas essenciais. Como primeiro passo, fui a cada apartamento de nosso prédio e perguntei se as pessoas aceitariam separar seus lixos vegetais. Elas prontamente concordaram: «Livrar-se do lixo sem nenhum problema?» - segundo eles, isso era bom demais para ser verdade. Recolhi o bagaço de cana-de-açúcar dos quiosques que vendem garapa e forrei algumas caixas e potes com ele. Depois coloquei um pouco de terra. Sobre esta, coloquei esterco que produzira com o lixo vegetal. Depois plantei mudas. Reguei cada uma delas com pesticida feito em casa de folhas esmagadas de neem. Assim formei meu pequeno jardim."

Criança de Mysore, Índia ${ }^{3}$

$$
\text { ...propondo... }
$$

"Pessoalmente, acho que se as mulheres receberem uma verdadeira educação, elas lutarão com firmeza para dar o melhor de si. Por exemplo, se eu não tivesse tido nenhuma educação, não estaria participando da Reunião Editorial da Edição de Crianças da Agenda 2I, dando minha contribuição para a publicação do livro para um futuro melhor."

Mary Edet, 15 anos, Nigéria ${ }^{4}$

\footnotetext{
3 idem: 59

${ }^{4}$ idem: 74
} 
... elutando ...

"Os jovens brasileiros querem que, antes de se cogitar a possibilidade de transpor águas do São Francisco, se faça:

* a recuperação dos mananciais, dos olhos d'água e das nascentes ao longo dos 2.700 km de extensão do Rio, fazendo o reflorestamento e resolvendo a questão fundiária, principalmente das áreas de preservação permanente (a menos de 30 metros do rio). A recuperação das Matas Ciliares é a forma mais sustentável de conter o assoreamento do Velho Chico;

* a despoluição do Rio São Francisco, através do tratamento dos esgotos e dos agrotóxicos que são despejados incessantemente pelos 504 municípios que fazem parte da bacia do São Francisco. Tornar o rio saudável é prioridade. Não adianta transpor águas poluídas, isso pode gerar incalculáveis danos ambientais à bacia receptora;

* programas de transformação dos 504 municípios em Sociedades Sustentáveis, para que, de forma participativa, os vários setores da sociedade possam executar e tornar realidade as duas propostas acima, tornando-as alternativas de desenvolvimento para o povo, e não para as grandes empreiteiras interessadas na obra."

João Ferreira, Movimento Nacional da Juventude Brasileira Contra a Transposição e em Defesa do Rio São Francisco, Carta ao Presidente Lula, em Defesa do Velho Chico ${ }^{5}$

Não percamos o barco!

\footnotetext{
${ }^{5}$ http://www.takingitglobal.org/express/panorama/article.html?ContentlD=6462\&start=0
} 


\section{REFERÉNCIAS BIBLIOGRÁFICAS}


ADAMS, Eileen; INGHAM, Sue - "Changing Places", Londres: Planning Aid of London \& The Children's Society, 1998.

ALMEIDA, Guido de - "O Professor que não Ensina", São Paulo: Summus, 1986.

ARANTES, Antonio A. - "O espaço da Diferença", Campinas: Editora Papirus, 2001.

CALDEIRA, Teresa Pires do Rio - "Cidade de Muros: crime, segregação e cidadania em São Paulo", São Paulo: Ed. 34/Edusp, 2000.

CALLIGARIS, Contardo - "A Adolescência", São Paulo: Publifolha, 2000.

CALVINO, Ítalo - "As Cidades Invisíveis", São Paulo: Cia. das Letras, 1990.

CERTEAU, Michel de - "A Invenção do Cotidiano 2", Petrópolis: Ed. Vozes. 2002.

CHAWLA, Louise - "Growing Up in an Urbanizing World", Sterling/VA: Earthscan/UNESCO, 2002.

DIETZSCH, Mary Julia Martins - "Leituras da Cidade e Educação", in Cadernos de Pesquisa, v. 36, n. I29, p. 727-759, set./dez., São Paulo: FEUSP, 2006.

DRISKELL, David - "Creating Better Cities with Children and Youth", Sterling/VA: Earthscan/UNESCO, 2002.

ECO, Umberto - "Como se faz uma Tese", São Paulo: Perspectiva, 2005.

ESTATUTO DA CIDADE (Lei I0.257/0I de 10 de julho de 200 I) Brasilia/DF: 200I.

FREINET, Celestin - "O Método Natural II: a Aprendizagem do Desenho", Lisboa: Editorial Estampa, 1977.

FREIRE, Paulo - "Educação como Prática da Liberdade", Rio de Janeiro: Ed. Paz e Terra, 1975. - "Pedagogy of the Oppressed" (30 $30^{\text {th }}$ ed.), Nova lorque: The Continuum Intl. Publishig Group Inc, 2005. 
GADOTTI, Moacir; PADILHA, Paulo Roberto; CABEZUDO, Alicia "Cidade Educadora: Princípios e Experiências", São Paulo: Cortez Editora, 2004.

GANDINI, Lella; GOLDHABER, Jeanne - "Duas Reflexões sobre a Documentação", in GANDINI, Lella; EDWARDS, Carolyn - "Bambini: A Abordagem Italiana à Educação Infantil", cap. 10, Porto Alegre: Artmed, 2002.

GIDDENS, Anthony - "As Conseqüências da Modernidade", São Paulo: Editora Unesp, 1991.

GODSCHALK, David R. - "Participation, Planning, and Exchange in Old and New Communities: a Collaborative Paradigm", Chapel Hill/Carolina do Norte: Center for Urban and Regional Studies, 1972.

GONÇALVES, Paulo Cássio - "Construção Coletiva da Paisagem", Dissertação de Mestrado, São Paulo: FAU USP, 2005.

GRAVELINE, Fyre Jean - "Circle Works: Transforming Eurocentric Consciousness", Halifax: Fernwood Publishing, 1998.

GROTH, Paul e BRESSI, Todd W. - "Understanding Ordinary Landscapes", Ann Arbor: Yale Press, 1997.

HART, Roger - "Children's Participation", Nova lorque: UNICEF, 1997.

HILLMAN, James - "Cidade e Alma", São Paulo: Studio Nobel, 1993.

JACOBS, Jane - "Morte e Vida das Grandes Cidades", São Paulo: Martins Fontes, 2001.

JACQUES, Paola Berenstein (org.) - "Apologia da Deriva", Rio de Janeiro: Casa da Palavra, 2003.

JELLICOE, Geoffrey Alan - "The Landscape of Man", Londres: Thames, 1975.

LERNER, Jaime - "O Vizinho", Rio de Janeiro: Record, 2005.

LIMA, Mayumi Watanabe de Souza - "Arquitetura e Educação", São Paulo: Studio Nobel, 1995. - "A Cidade e a Criança", São Paulo:

Studio Nobel, 1989. 
LIMA, Catharina P. C. dos Santos - "A Construção Social da Paisagem", in OLIVEIRA, Marcos Guedes de (org.). "Brasil e EUA no Novo Milênio", Recife: NEA/Ed. Universitária da UFPE, 2004. - "Miranda Magnoli, Orientadora: Um Processo Dialógico e Compreensivo de Construção de Conhecimento", in FAU USP - Revista Paisagem e Ambiente, n²1, São Paulo: 2006.

LOECKX, André; SHANNON, Kelly; TUTS, Rafael; VERSCHURE, Han "Urban Trialogues", Nairobi: UN-HABITAT, 2004.

LYNCH, Kevin - "The Image of the City", Cambridge, Massachussets: The MIT Press 2002.

MAGALHÃES, de Manuela R. - "A Arquitetura Paisagista", Lisboa: Editorial Estampa, 200 I.

MARINO, dian. "Wild Garden" - Toronto: Between the Lines, 1997.

MCBRIDE, Jason; WILCOX, Alana - "Utopia", Toronto: Coach House Books, 2005.

MEC - "Parâmetros Curriculares Nacionais" (vol. 'Meio Ambiente e Saúde' e 'Arte'), Brasilia: 1997.

MEINIG, Donald W. - "The Interpretation of Ordinary Landscapes", Nova lorque: Oxford University Press, 1979.

MESMIN, Georges - "L'Enfant, l'Architecture et l'Espace", Tournai: Ed. Casterman, 1971.

MOORE, Robin \& WONG, Herb H - "Natural Learning", Berkeley: MIG Communications, 1997.

MORIN, EDGAR - "Os Sete Saberes Necessários à Educação do Futuro", São Paulo: Cortez Editora, 2003.

MYANAKI, Jacqueline - "A Paisagem no Ensino da Geografia: uma Estratégia Didática a partir da Arte", Dissertação de Mestrado, São Paulo: Depto. Geografia FFLCH USP, 2003. 
NOVAES, Washington - "A Década do Impasse", São Paulo: Ed. Estação Liberdade, 2002.

OLIVEIRA, Claudia - "O Ambiente Urbano e a Formação da Criança", São Paulo: Aleph, 2004.

ONU - "Youth Participation in Decision-making" in "World Youth Report", Nairobi: 2003.

OSTROWER, Fayga - "A Construção do Olhar" in NOVAES, Adauto (org) "O Olhar", São Paulo: Companhia das Letras, 1988.

ORTEGA, Francisco - "Para uma Política da Amizade", Rio de Janeiro: Relume Dumará, 2000.

OSTROWSKY, Maria de Sampaio Bonafé - "Sistemática Integrada para Controle de Inundações em Sub-bacias Hidrográficas Urbanas - Estudo de Caso: A Bacia do Córrego Pirajuçara", Tese de Doutorado, FAU USP, 2000.

PECHMAN, Robert Moses - "Cidades Estreitamente Vigiadas", Rio de Janeiro: Ed. Casa da Palavra, 2002.

PEREIRA, Raul - "Projeto Mutirão: Participação Popular e Melhoramentos nos Bairros de Osasco", Osasco: Prefeitura Municipal de Osasco, 1983. - "O Sentido da Paisagem e a Paisagem Consentida". Tese de Doutorado, São Paulo: FAU USP, 2006.

PERROTTA, Claudia - "Um texto pra chamar de seu", São Paulo: Martins Fontes, 2004.

PONTUSCHKA, Nídia Nacib - "Um Projeto... Tantas Visões: Educação Ambiental na Escola Pública", São Paulo: LAPECH-FEUSP/AGB, 1996.

PREFEITURA MUNICIPAL DE SANTO ANDRÉ; AGÊNCIA CANADENSE PARA O DESENVOLVIMENTO INTERNACIONAL - "Educação Ambiental, Jovens e Gestão Participativa", São Paulo: Annablume, 2004.

PRONSATO, Sylvia A. Dobry - "Arquitetura e Paisagem: Projeto Participativo e Criação Coletiva", São Paulo: Annablume/Fapesp/Fupam, 2005. 
SANOFF, Henry - "Participatory Design", Carolina do Norte: Bookmasters Inc., 1990.

SEGURA, Denise de Souza Baena - "Educação Ambiental na Escola Pública", São Paulo: Annablume/FAPESP, 2004.

SCHAMA, Simon - "Paisagem e Memória", São Paulo: Cia. das Letras, 1996.

SCHIEL, Dietrich; MASCARENHAS, Sérgio; VALEIRAS, Nora; SANTOS, Silvia A. M. dos (orgs.) - "O Estudo de Bacias Hidrográficas - Uma Estratégia para Educação Ambiental", São Carlos: RiMa Editora, 2002.

SEVCENKO, Nicolau - "A corrida para o Século XXI", São Paulo: Companhia das Letras, 200I.

SPIRN, Anne Whiston - "O Jardim de Granito", São Paulo: EDUSP, 1995. - "The Language of Landscape", New

Haven/Londres: Yale University Press, 1998.

TEIXEIRA, Elenaldo Celso - "O Local e o global", São Paulo: Cortez Editora, 200I.

THIOLLENT, Michel - "Metodologia da Pesquisa-ação", ( $\mid 4^{a}$ ed. aum.), São Paulo: Cortez Editora, 2005.

TSOUKALA, Kyriaki - "L'Image de la Ville chez l'Enfant", Paris: Ed. Anthropos, 200I.

UN-HABITAT - "Tools to Support Participatory Urban Decision Making", Nairobi: 2003.

UNICEF - "Missão Terra: o Resgate do Planeta", São Paulo: Melhoramentos, 1994.

WEFFORT, Madalena Freire - "A Paixão de Conhecer o Mundo", São Paulo: Ed. Paz e Terra, 1983. 
ANEXOS 


\title{
ANEXO I \\ Letra de Música do cd "PAULO MIKLOS", solo, lançado pela Warner em 1994
}

\author{
A Mesma Praça (Paulo Miklos) \\ Sou do chão negro asfalto da avenida São João \\ Sob o escuro manto fumaça sombra do Minhocão \\ Sob o céu cinzento de São Paulo insano e mau \\ Brasileiro cuspido dos canhões na Hungria cigano e bárbaro \\ Bastardo dos portugueses mouro feroz e bárbaro \\ Desorientado dos beijos de línguas e lugares embaralhados \\ Que quando se beija não se ouve palavra
}

Da rua Apa quando desaba a Barra Funda dos prostíbulos De toneladas de poeira e fuligem sobre a poesia Judeu de disfarce católico ateu crente no candomblé De todas as fugas e enfrentamentos continuo de pé Aqui nesta esquina não se ouve nem pensamento

Entre as paradas militares nos meus dez anos de idade A bola no alto da estátua da Marechal Deodoro De quando meninos se encontravam na rua E todo menino era menino de rua E todo homem acreditava estar com um pé na lua

A minha é a nação gigante abandonada no berço Com braços e pernas formigando sobre o próprio peso Eu mesmo petrificado diante de tais edifícios De volta a esta praça prá dar sombra aos mendigos Dessa cidade que me deu nome e não me dá ouvidos. 


\section{Rua de Ipanema muda para ser a mais atraente do Rio}

\section{Esforço de comerciantes aumenta o charme e o conforto da Garcia D'Ávilo \\ CLARISSA THOME}

$\mathbf{R}$

IO - Em que rua você pode esbarrar com Mamertu Mader, Júlia Lemzendo compras, na outra esquina encontrar Glória Maria saboreando um sorvete da Mil Frutas e ainda se deparar com o titã Toni Bellotto num charmoso café? Na Garcia D'Ávila, a rua mais sofisticada de Ipanema, que reúne grifes como Elle et Lui Maison, Louis Vuitton e Mont Blanc, as joalherias Cartier, Antônio Bernardes e Amsterdam Sauer, e as butiques Mixed, PL Bis e K\&T.

Além de sofisticada, os comerciantes resolveram transformá-la na rua mais atraente do bairro. Começaram com o tapete vermelho, que há dois anos cobre as calcadas no periodo de Natal. E propuseram à prefeitura uma reforma completa, que prevê plantio de ipês, pedras portuguesas brancas nas calçadas e fiacão subterrânea.

Uma instituição financeira está interessada em arcar com metade do custo da obra, orcada em RS 3 milhões, em troca de manter publicidade por 50 anos na rua. Esse ponto está em estudo pela Coordenação de $\mathrm{Pu}$ blicidade da Secretaria de Fazenda. Se tudo der certo, a reforma comeca em marco.

"Estava faltando para o Rio uma rua que identificasse a cidade. Milão tem a Via Montenapoleone, Nova York tem a 5. ${ }^{2}$ Avenida, Paris tem a Champs-Elysées. Agora o Rio tem a Garcia D'Ávila", afirma o italiano Fabrizzio Giuliadore, dono do simpático Alessandro \& Frederico Café.

Há três anos lojas começaram a ser reformadas. A Elle et Lui foi uma das pioneiras. Praticamente colocou abaixo o pré-

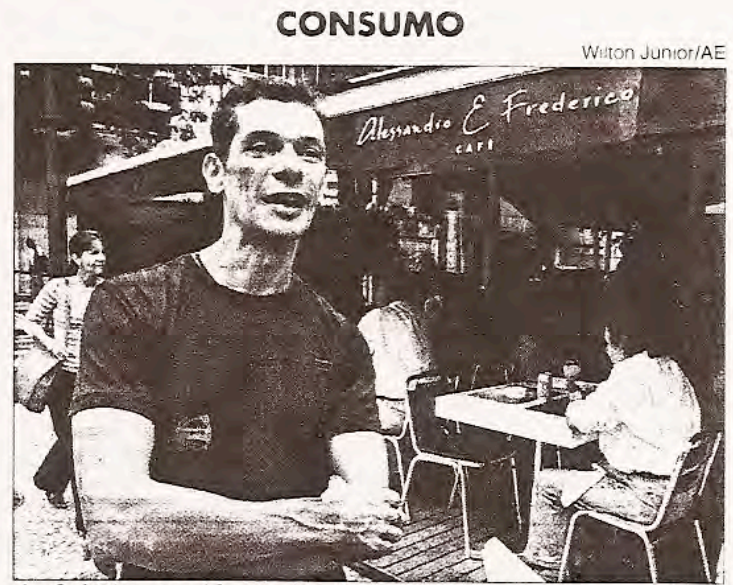

André Piva, no Alessandro \& Frederico: 'voyeurismo carioca'

dio de quatro andares e reabriu como butique de móveis, com projeto da arquiteta Bel Lobo.

A tendência se espalhou.

Bel Lobo ficou conhecida com a "arquiteta da Garcia". Fez projetos para PL Bis, K\&T, H Stern Home e café Via 7. "Essa é uma rua muito viva, muito gostosa, que você passeia e ela te consome. E tem a beleza de começar na Lagoa Rodrigo de Freitas e terminar na Praia de Ipanema", diz Bel.

A reforma mais recente foi da Louis Vuitton, que, depois de 13 anos na rua, ganhou prédio novo e fachada com malha de aco inoxidável, vidro e aço escovado. Outras duas lojas estão em obras.

Na Garcia D’Ávila, a sofisticacão de uma loja como a $\mathrm{K} \& \mathrm{~T}$, convive com a mercearia e tinturaria remanescentes do antigo comércio. É esse charme da rua que atrai pessoas como o arquiteto André Piva, frequientador assíduo do Alessandro \& Frederico. "O Rio é uma cida-

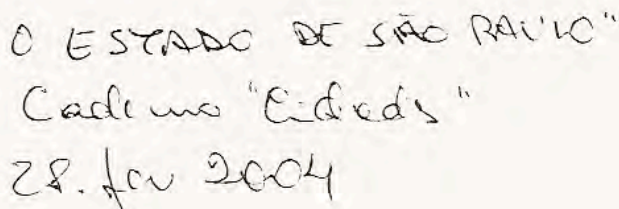

Le voltada para o dia. As pessoas sentam na calçada para ver quem está passando, ficam nesse voyeurismo carioca."

Shopping - Ao se mudar para 7 Garcia D'Ávila, o designer de jóias Antônio Bernardo achou que a sofisticação da rua não combinava com calcadas desiguais, canteiros abandonados. Comecou a reunir os comerciantes e estava ciantes e estava criada a Associação de Amigos la (Ama Garcia) Eles apresentaram o projeto de revitalização à prefeitura, o Instituto Pereira Passos, órgão da Secretaria de Urbanismo, fez o croqui das mudanças e a execução do projeto está em fase negociação.

"A idéia é fazer como um shopping a céu aberto, com as lojas funcionando no mesmo horário e seguranças. Estamos todos nesse espírito de oferecer um ambiente renovado, com mais conforto e um aspecto único, de charme e beleza." Bernardo agora se empenha em atrair para a associação dez dos 30 comerciantes que ainda estão de fora - de grandes, como a $\mathrm{H}$. Stern, a pequenos, mas não menos charmosos, como a mercearia Casa Cerqueira.

Briga - No Leblon, uma obra provocou um racha entre lojistas da Rua Dias Ferreira. Tudo comecou com um pleito da Associacão Comercial do Leblon, com o apoio de pequenos comerciantes, para refazer o esgoto da rua, embutir a fiação elétrica e padronizar as calçadas. Mas os donos de points prestigiados, como Celeiro, Ateliê Culinário e uadrucci, não querem que se mexa na calcada, temendo queda no número de consumidores por conta do movimento de operários. $\mathrm{O}$ resultado foi uma guerra de abaixo-assinados. Os comerciantes contrários à mudanca reuniram cerca de sinaturas, os favoráveis, 46. Até os moradores foram envolvidos - 250 deles assinaram um manifesto pedindo a obra. 
ANEXO III

\section{The Politics of Happiness}

by Enrique Peñalosa and Susan Ives

The name Bogota conjures images of kidnapping, murder, and drug wars. But today's Bogota is safer than Washington, D.C., or Baltimore. A visionary mayor discovered the secret to making his city safe. Enrique Penalosa tells Susan I ves the story.

Enrique Penalosa, mayor of Bogota, Colombia, 1995-1998.

We really have to admit that over the past 100 years we have been building cities much more for mobility than for people's well-being. Every year thousands of children are killed by cars. Isn't it time we build cities that are more child-friendly? Over the last 30 years, we've been able to magnify environmental consciousness all over the world. As a result, we know a lot about the ideal environment for a happy whale or a happy mountain gorilla. We're far less clear about what constitutes an ideal environment for a happy human being. One common measure of how clean a mountain stream is is to look for trout. If you find the trout, the habitat is healthy. It's the same way with children in a city. Children are a kind of indicator species. If we can build a successful city for children, we will have a successful city for all people.

When I was elected mayor of Bogotá and got to city hall, I was handed a transportation study that said the most important thing the city could do was to build an elevated highway at a cost of $\$ 600$ million. Instead, we installed a bus system that carries 700,000 people a day at a cost of $\$ 300$ million. We created hundreds of pedestrian-only streets, parks, plazas, and bike paths, planted trees, and got rid of cluttering commercial signs. We constructed the longest pedestrian-only street in the world. It may seem crazy, because this street goes through some of the poorest neighborhoods in Bogotá, and many of the surrounding streets aren't even paved. But we chose not to improve the streets for the sake of cars, but instead to have wonderful spaces for pedestrians. All this pedestrian infrastructure shows respect for human dignity. We're telling people, "You are important-not because you're rich or because you have a Ph.D., but because you are human." If people are treated as special, as sacred even, they behave that way. This creates a different kind of society.

We began to experiment by instituting a car-free day on a weekday. In a city of about 7 million people, just about everybody managed to get to work by walking, bicycling, bus, even on horseback-and everybody was better off. There was less air pollution, less time sitting in traffic, more time for people to be productive and enjoy themselves. Every Sunday we close 120 kilometers of roads to motor vehicles for seven hours. A million and a half people of all ages and incomes come out to ride bicycles, jog, and simply gather with others in community.

We took a vote, and 83 percent of the public told us they wanted to have carfree days more often. Getting people out of their cars is a means of social integration. You have the upper-income person sitting next to the cleaning lady on the bus. 
Parks for urban peace Parks have a very powerful role to play as equalizers of society. We almost always meet under conditions of social hierarchy. At work, some people are bosses and others are employees; at restaurants, some people are serving and others are being served. Parks are the gathering place for community. They create a sense of belonging. Everybody is welcome regardless of age, background, income, or disabilities. This creates a different type of society.

Today we see images of the beautiful Earth taken from a spaceship, and we think of it as our planet. But in fact, there are very few places on the planet to which the public has access. Most of the land is privatized, and public spaces are very, very scarce. The fact is, upper-income people have always had access to nature and recreation. They go to country houses, golf clubs, restaurants, hunting preserves. What do the poor, especially in the Third World, have as an alternative to television? All poor people have are public spaces, so this is not a luxury. They are the minimum a democratic society can provide to begin to compensate for the inequalities that exist in society.

Since we took these steps, we've seen a reduction in crime and a change in attitude toward the city. In the worst recession we've ever had, people were asked to pay a 10 percent voluntary tax to support various city services, including parks. More than 40,000 people did so, which I think speaks to the greater sense of community people feel.

If we in the Third World measure our success or failure as a society in terms of income, we would have to classify ourselves as losers until the end of time. Given our limited resources, we have to invent other ways to measure success, and that could be in terms of happiness. It may be in how much time children spend with their grandparents, or the ways in which we are able to enjoy our friendships, or how many times people smile during the week. A city is successful not when it's rich but when its people are happy. Public space is one way to lead us to a society that is not only more equal but also much happier.

Perhaps the biggest challenge to world security is environmental and social sustainability in the world's fastest-growing cities. The population of cities in the Third World is growing by more than 80 million inhabitants per year, which means there will be some 2 billion people living in these cities within the next 25 to 30 years. In dense cities such as Bogotá, São Paolo, Jakarta, and Mexico City, there have been practically no places where people can come into contact with nature, safely play outside, or meet others in society as equals. And we have seen firsthand how living in poor conditions can lead to social problems, including extremism and even terrorism. We need food and housing for survival, but there are even higher types of needs-needs related to happiness. If you look at it that way, parks become as necessary to a city's health-physical and spiritual-as the water supply. 


\section{ANEXO IV}

Letra de Música do cd "PAULO MIKLOS", solo, lançado pela Warner em 1994

\section{De quem são as Cidades (Paulo Miklos)}

Nós somos da cidade

$\mathrm{E}$ as cidades de quem são?

De quem são as cidades?

Mesmo os que nasceram aqui

São tão diferentes entre si

E os que chegaram depois são ainda mais diferentes de nós

Mais próximos que parentes

Vizinhos sem querer

Cidades que eram diferentes

Começam a se parecer

Esta não é mais a cidade onde eu nasci

Eu moro aqui

Os incomodados não se mudam

$\mathrm{E}$ os que incomodam não estão nem aí

De quem são as cidades?

Nós somos da cidade

Mas as cidades de quem são?

Esta cidade não nos quer mais aqui

Nós somos um povo orgulhoso

Cada um sabe cuidar de si

Mas ninguém quer olhar pelo que é de todos

A água o gás a luz lugar nunca vai faltar Nem os incomodados se mudam

$\mathcal{N}$ em mudam os que costumam incomodar 


\section{ANEXO V}

\section{UMA ALEGORIA OU UM CONTO DE FADAS?*}

Era uma vez um povo muito orgulhoso que vivia no topo de uma montanha. Daquele pico, parecia, eles podiam ver tudo, todos os lugares. Nuvens diárias obscureciam o horizonte distante, mas ocasionalmente eles vislumbravam uma enorme montanha à distância. Apesar dessas revelações momentâneas, estavam satisfeitos acreditando que o mundo todo era o que eles podiam ver em sua própria montanha. Por causa disso não percebiam que sua montanha era na verdade um contraforte, um dos muitos que circundavam a imensa montanha distante. Eles também não sabiam que outras povos, em outros contrafortes, também acreditavam que o que viam de seu própria montanha era o mundo todo, tudo, todos os lugares, embora aquele fosse apenas um de muitos contrafortes.

Certo dia um terrível cataclismo assolou a terra. Um tremor violento chacoalhou os contrafortes até que eles começaram a desmoronar. Todos os povos orgulhosos tiveram que descer de suas próprias montanhas para procurar refúgio nas terras baixas, na base da grande montanha. Lá descobriram que outras povos, de outros contrafortes, também haviam descido para as terras baixas para escapar à fúria da natureza. Nesse momento, de repente, a terra se aquietou, as nuvens se elevaram, e todos os povos puderam ver, pela primeira vez, a imensa montanha em toda sua glória monumental, ao passo que antes eles conheciam-na apenas através de relances fugazes.

Mas a natureza ainda não estava quites com aqueles povos. Uma grande enchente veio trovejando pelo vale e todas as povos escalaram para as terras mais altas do lado da imensa montanha, para escapar ao dilúvio. Dia após dia as águas da enchente subiam. Todos os povos perceberam que teriam que subir a montanha juntos para se salvar. Mas conforme começaram a subir, grandes disputas espoucaram entre os diferentes povos, pois cada um tinha sua própria idéia sobre a melhor maneira de escalar a montanha. Afinal de contas, cada povo havia acreditado desde há muito tempo que tinha visto tudo, todos os lugares, e portanto sabiam tudo de tudo. Era-lhes difícil admitir que haviam visto apenas uma parte da imensa montanha e apenas a partir do ângulo de visão de seu contraforte particular.

Como as águas continuavam a subir, as clamorosas disputas deram lugar às urgências da sobrevivência. Apesar de seus diferentes pontos de vista, eles tinham uma coisa em comum: era preciso escalar a montanha para sobreviver. Enquanto debatiam seu dilema, chegaram a uma nova revelação. Cada um dos diferentes povos conhecia uma parte diferente da montanha - um sabia onde aconteciam as avalanches, um sabia onde se podia encontrar água, outro conhecia a passagem por um terreno difícil. Chegaram então a uma nova visão de tudo, de todos os lugares, uma nova visão da 
verdade. Perceberam que estavam olhando de formas diferentes para a mesma montanha, e uma vez que trocaram visões com o propósito comum de subir ao topo da montanha da verdade, desenvolveram uma compreensão da montanha, mais completa do que cada um havia desenvolvido separadamente. Formaram uma comunidade de alpinistas e iniciaram a difícil escalada. Eles ainda estão escalando e nós não sabemos o fim da história.

WONG, F.F. - Diversity and Community: right objectives and wrong arguments. Change: The Magazine of Higher Learning, July/August. Washington, DC: Heldred Publications, 1991.

Reprinted with permission in: "Community Culture and Environment - A Guide to Understanding a Sense of Place". Environmental Protection Agency. United States. 


\section{ANEXO VI}

GROWING UP IN CITIES (Crescendo em Cidades)

é uma iniciativa internacional de pesquisa-ação para criar cidades melhores com crianças e jovens. Ela envolve crianças, jovens e adultos como co-pesquisadores na avaliação de ambientes locais para planejar e implementar mudanças. Buscamos:

- Capacitar jovens para expressar suas perspectivas e opiniões sobre o lugar onde vivem.

- Compreender como jovens percebem e usam seu ambiente.

- Criar oportunidades para a participação e liderança de crianças e jovens.

- Valorizar insights e habilidades criativas dos jovens.

- Integrar jovens e adultos na defesa de mudanças.

- Educar autores de políticas públicas, profissionais e o público em geral acerca dos resultados e processos da pesquisa.

- Transformar ambientes locais para torná-los lugares que dêem mais apoio aos residentes.

\section{PRINCÍPIOS ORIENTADORES}

Vozes + Participação de Jovens

- Ser inclusivo em relação aos jovens.

- Facilitar diferentes tipos de participação significativa que capacite jovens a fazer escolhas.

- Oferecer ferramentas e espaços para crianças e jovens expressarem suas perspectivas e idéias.

- Investir os jovens de propriedade do projeto; garantir transparência em todos os aspectos do projeto.

- Agir com ética; proteger os interesses e direitos de crianças e jovens.

$$
\text { Pesquisa + Ação }
$$

- Manter o foco no ambiente local como um ponto de partida para a exploração de questões da comunidade pelos jovens.

- Utilizar métodos envolventes de pesquisa participativa e solução de problemas.

- Trabalhar com objetivos de longo prazo; garantir que os participantes percebam resultados e sucessos a curto prazo.

- Criar políticas públicas favoráveis a crianças e jovens e melhorar a forma como instituições e comunidades funcionam.

\section{Redes + Parcerias}

- Construir redes em nível local, regional, nacional e internacional.

- Documentar e compartilhar conhecimento com as redes do projeto, aprendendo tanto com sucessos como com fracassos.

- Reconhecer todos que contribuem.

- Apoiar a colaboração entre grupos de projeto, pais, organizações comunitárias, representantes do poder público, e outros que têm o poder de efetivar mudanças.

- Encorajar relações positivas entre os jovens e de jovens com adultos.

- DIVIRTAM-SE!

Somos uma rede de indivíduos e organizações comprometidos com a pesquisa-ação participativa com jovens e crianças para a mudança de comunidades. Para maiores informações, visite www.unesco.org/most/GUiC 


\section{ANEXO VII}

\section{A Cidade Escondida}

\section{Apresentação}

Vivemos hoje numa metrópole nossa desconhecida; não só não conhecemos todo o município de São Paulo, camo também não conhecemos o bairro em que habitamos. Muitas vezes andamos de carro e não vemos o que existe à nossa volta, passamos por alguns lugares com pressa e não prestamos atenção a esses lugares por onde passamos. Às vezes passam despercebidos córregos escondidos, árvores floridas, pessoas que vivem no mesmo bairro, e um bocado de outras coisas. Nesse sentido, minha proposta é colocar as mãos, e a cabeça, à obra, para que possamos conhecer melhor o lugar em que vivemos.

Objetivo: desenvolver a percepção com relação à cidade, e mais especificamente ao bairro em que se vive, de forma a contribuir na formação de cidadãos mais conscientes e participativos no que diz respeito aos espaços públicos.

O curso será dividido em 3 partes:

1. apresentação de material/informações sobre a formação das cidades e em especial da cidade de São Paulo;

2. levantamento de material/informações sobre o bairro em que se localiza a escola - esse levantamento será feito através de observação, desenhos, entrevistas, pesquisa, fotografias, e outras formas que forem sugeridas pelos alunos; essa fase deverá incluir contato com a Sub-prefeitura do Butantã para conhecimento do Plano Diretor para a região;

3. apresentação de projetos participativos para áreas públicas já executados Parque Pinheirinho d'Água (região Noroeste de São Paulo, Mutirão de plantio de árvores (Osasco), Projeto Pomar (Diadema), projeto da Praça Maria Quitéria (Santo André);

4. projeto - os alunos escolherão um projeto a ser executado, sobre o bairro; para auxiliar na eleição deste trabalho, será oferecido um cardápio de opções, que servirá apenas como sugestão, a saber:

$>$ livro

$>$ maquete

$>$ exposição de fotos

$>$ site na internet

$>$ projeto para área pública.

Esse projeto poderá ser feito individualmente ou em grupo e será acompanhado pela professora. Ele exigirá algum trabalho extra-classe, pois o tempo que teremos em classe não será suficiente para sua execução. 
Algumas questões que serão discutidas ao longo do curso:

- público x privado

- a natureza na cidade - vegetação, rios e outros corpos d'água, etc.

- cidadania/participação

- o "habitar"

Bibliografia

- "As Cidades Invisíveis" Ítalo Calvino

- "Reinvente seu Bairro"

Cândido Malta Campos Filho

- outros textos selecionados no decorrer do curso

$\underline{\text { Avaliação }}$

A avaliação do curso será feita de parte a parte, ou seja, a professora fará a avaliação do desempenho dos alunos, de acordo com a orientação da escola, e os alunos, a avaliação da professora; sempre em função dos objetivos iniciais contidos nesta proposta.

I Observação posterior: a avaliação deve ser feita não apenas de parte a parte, mas também de forma conjunta. 


\section{ANEXO VIII}

GUiC - Growing Up in Cities

Algumas atividades da Oficina GUiC São Paulo

\section{Atividade $\mid$}

Formar uma dupla com alguém que não se conhece e rapidamente responder às seguintes perguntas: nome, onde cresceu, onde estuda/trabalha e o que faz, pensar em mais uma ou duas perguntas para fazer para seu par, compartilhar as respostas com o grupo.

Atividade 2

Fazer com que as pessoas se agrupem baseadas em características similares... respondendo às seguintes perguntas: Quem tem mais de 30 anos? Menos? Quem tem um irmão/ã, dois, três, mais? Quem já trabalhou com jovens ou não? Quem já trabalhou com meio ambiente? Quem já trabalhou com pesquisa-ação ou não? Quem já saiu do Brasil para 3 países? 2? I? Nenhum? Quem tem olhos pretos, azuis, castanhos, verdes, outros? Quem prefere passar férias na praia, na montanha, na cidade, outros? Quem tem I filho, 2, 3, mais, nenhum?

\section{Atividade 3}

Esta atividade é para lembrarmos e compartilharmos nossas experiências de quando éramos jovens. Precisamos saber o nosso papel quando trabalhamos com jovens que podem ter crescido com experiências similares ou diferentes, e também, lembrarmos como é ser jovem.

Parte I - ao som de alguma música instrumental: escolher um ano de sua vida quando você tinha entre 10 e 15 anos; Você vivia numa área rural ou urbana? Onde passava seu tempo? Com quem você passava seu tempo? Sozinho? Com amigos? $\bigcirc$ que você fazia todos os dias? Onde você ia? 
Parte 2 - em silêncio: pensar sobre memórias da infância; usando um lápis e um pedaço de papel, desenhar sua experiência; usar símbolos, para descrever lugares, pessoas, experiências, gostos, desgostos.

Parte 3 - agrupar-se de 3 em 3 para discutir os desenhos; acompanhar os desenhos com a história do que você está descrevendo; $\bigcirc$ que é similar entre as pessoas do grupo? $\bigcirc$ que é diferente? Falar de seus sentimentos da época em que era criança;

Parte 4 - socialização das histórias de cada grupo: $\bigcirc$ que aprenderam uns com os outros? $\bigcirc$ que você aprendeu sobre você mesmo? Por que fizemos essa atividade? Como essa atividade pode ser útil para você como líder de projeto que trabalhe com jovens? Como podem suas experiências como uma pessoa jovem serem similares ou diferentes daquelas dos jovens com quem você possa trabalhar?

\section{Atividade 4}

Dividir o grupo em dois círculos concêntricos, cada pessoa do círculo do meio de frente para outra do de fora. Um ou dois minutos para responder a perguntas do colega à sua frente; em seguida mover-se para o seguinte, até girar o círculo todo. Perguntas a serem feitas: $\bigcirc$ que de interessante você fez hoje cedo? Qual foi sua parte favorita do dia de ontem? Descreva uma situação de quando você era jovem e alguém tentou tirar algum poder que você tinha (situação simples)... como você se sentiu? Como reagiu? Por que você quer trabalhar com jovens? Qual seria uma barreira para um bom trabalho com jovens?

Ao fim de cada atividade é importante que se faça perguntas como: $\bigcirc$ que você achou desta atividade? Fale de algo interessante que você descobriu sobre alguém. Você ficou sabendo de algo surpreendente sobre alguém ou descobriu algo surpreendente sobre você mesmo? Como esta atividade poderia funcionar com jovens? Que outras perguntas poderíamos fazer? 